\title{
EFEITOS DA APLICAÇÃO DE PRODUTOS DO BASALTO DE ALTERAÇÃO HIDROTERMAL NAS PROPRIEDADES FISICO-QUIMICAS DE UM LATOSSOLO VERMELHO ESCURO TEXTURA ARENOSA / MÉDIA
}

\section{ADEMERCIO ANTONIO PACCOLA}

Orientador: Dr. ANTONIO CARLOS TEIXEIRA MENDES

Tese apresentada a Escola Superior de Agricultura «Luiz de Queiroz", da Universidade de São Paulo, para obtenção do título de Doutor em Agronomia. Área de Concentração:

Solos e Nutrição de Plantas

P I R A C I C A B A

Estado de São Paulo - Brasil

Novembro - 1981 
.ii .

"Estamos tão distantes de conhecer todos os agentes da natureza e seus diversos modos de ação, que serā pouco filosófico o negar a existência de fenômenos, unicamen te porque sejam inexplicảveis no estado atual de nossos conhecimen tos"

LAP LACE

(Ensaio Filosófico sobre as Proba bilidades - 1814, p. 110). 
$\AA$

MARILENE ,

com quem divido os momentos de tris teza e somo as alegrias, que me com preende e me auxilia nas horas difí ceis com seu amor;

A

ALESS ANDRA, que me fez sentir a continuidade da vida e, que me abranda o coração com seu olhar meigo e o carinho de suas pequeninas mãos;

AOS

MEUS PAIS E I RMAOOS,

Que com simplicidade e humildade sempre souberam dar o carinho e o apoio necessários à jornada da mi nha vida. 
Durante a execução desta pesquisa foi de vital importância a participação e colaboração de várias pessoas e entidades a quem não podemos deixar de fazer referência nomi nal.

Assim, queremos em primeiro lugar agradecer à Universidade Estadual Paulista "Julio de Mesquita Filho" atra vés do Departamento de Ciências Ambientais da Faculdade de Cí ências Agronômicas onde prestamos nossos serviços, que permi tiu a execução de grande parte das análises e desenvolvimento deste trabalho.

Nas pessoas dos colegas Helcio Rocha Galhego, Carlos Roberto Espindola e Luiz Lonardoni Foloni, pelas palavras de estímulo e ambiente de amizade.

Dos funcionários Joel Campos dos Santos pela presteza no serviço de datilografia, Adalberto Francisco dos Santos pela dedicação e impecabilidade na execução dos gráficos e desenhos, Dirce Antunes de Oliveira Nascimento e Aparecí do Pires de Campos pelas incansáveis horas de serviço de laboratório, Ana Cristina Pardini de Melo, Antonio Mariano da Si 1 va, Vicente Venegas, Valdomiro Rossi e Daniel Bozzoni Filho, indiretamente pela dedicação nos serviços paralelos que nos ca bia acompanhar.

Ao Departamento de Ciências do Solo pela realização de inúmeras análises no Espectrômetro de Absorção Atômi ca. 
lista S/A pelo valioso auxílio material e financeiro à execu ção da parte experimental de campo e várias anälises rotine ras do solo.

Ao colega Erseny João Nelli pela sua presteza nos serviços de montagem do ensaio de campo bem como nas cole tas de amostras e catalogação desses resultados.

Aos colegas José Luiz I. Demattê pela cessão do equipamento de raios-X para análises roentgnogräficas da fra ção argila, Henrique Bergamim Filho pelas anālises espectrográ ficas do basalto alterado, e a todos que de uma forma indireta nos auxiliaram na execução deste trabalho, 


\section{INDI CE}

Página

RESUMO $\ldots \ldots \ldots \ldots \ldots \ldots \ldots \ldots \ldots \ldots \ldots \ldots \ldots \ldots \ldots \ldots \ldots \ldots \ldots$

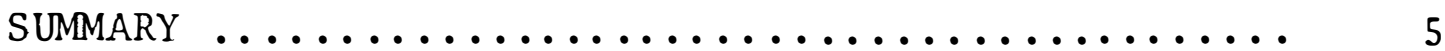

1. INTRODUÇAO $\ldots \ldots \ldots \ldots \ldots \ldots \ldots \ldots \ldots \ldots \ldots \ldots \ldots \ldots \ldots$

2. REVISÃO DA LITERATURA $\ldots \ldots \ldots \ldots \ldots \ldots \ldots \ldots \ldots \ldots \ldots$

2.1. Geologia e Solos ...................... 11

2.2. Físico-Química de Solos e Argilas .......... 18

3. MATERIAIS E METODOS $\ldots \ldots \ldots \ldots \ldots \ldots \ldots \ldots \ldots \ldots . \ldots \ldots$

3.1. Localização e Tempo de Duração do Ensaio ..... 55

3.2. Solo ........................... 56

3.3. Basalto Alterado .................... 58

3.4. Delineamento Experimental ............. 59

3.5. Instalação e Condução do Ensaio ............ 63

3.6. Determinações de Laboratório ............. 63

3.6.1. Análises químicas do solo e do basalto alterado ......................... 63

3.6.1.1. Determinação de $\mathrm{pH}$ e $\Delta \mathrm{pH} \ldots . .64$

3.6.1.2. Determinações de matéria orgânica Hidrogênio, Alumínio, Po tāssio, Fósforo, Cālcio, Magnẹe sio e Cloreto................

3.6.1.3. Determinação da matéria orgâni ca pela $\mathrm{H}_{2} \mathrm{O}_{2}$, remoção dos óxi dos de ferro livres e preparação de lâminas para raios-X .. 
3.6.1.4. Determinação da CTC ........ 66

3.6.1.5. Determinação do pHo ........ 66

3.6.1.6. Determinação das cargas permanentes $\left(\sigma_{p}\right) \ldots \ldots \ldots \ldots \ldots \ldots 66$

3.6.1.7. Determinação das cargas varia veis $\left(\sigma_{v}\right) \ldots \ldots \ldots \ldots \ldots \ldots, 69$

3.6.1.8. Determinação do ZPNC ....... 69

3.6.1.9. Determinação da superfície es pecífica ............... 70

3.6.1.10.Espectrografia de emissão .... 71

3.6.1.11.Determinação das relações de atividades .............. 72

3.6.1.12. Coeficiente, de seletividade . 74

4. RESULTADOS E DISCUSSAO .................... 75

4.1. Geologia e Solos ..................... 75

4.1 .1 . Geologia ..................... 75

4.1.2. Solos $\ldots \ldots \ldots \ldots \ldots \ldots \ldots \ldots \ldots \ldots .6 \%$

4.2. Interação entre Solos e Basalto Alterado ..... 85

4.3. Análises Químicas .................. 87

4.3.1. Do basalto alterado ............. 87

4.3 .2 . Do solo ..................... 89

4.3.3. Do experimento ................ 89

4.4. Características Eletroquímicas do Basalto Alte rado e do Solo sob Efeito dos Diversos Trata

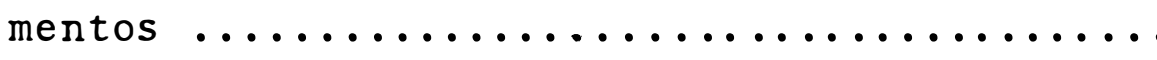


.viii.

Página

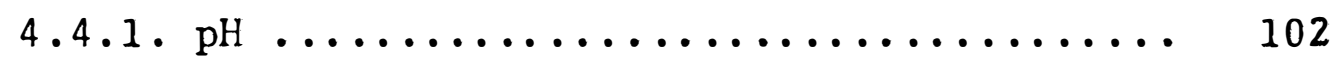

4.4.2. pHo (ou ZPC) $\ldots \ldots \ldots \ldots \ldots \ldots \ldots \ldots .108$

4.4.3. Ponto de carga líquida igual a zero (ZPNC ou PCLZ) $\ldots \ldots \ldots \ldots \ldots \ldots \ldots \ldots \ldots$

4.4.4. Superfície específica e cargas de super fície ....................... 131

4.4.5. Densidade de carga, cargas permanentes e cargas variāveis ................ 134

4.4.6. Capacidade de troca catiônica (CTC) ... 140 4.4.7. Relações iônicas, relações de ativida des e coeficiente de seletividade .... 145

4.4.8. Titulação potenciométrica .......... 150

4.4.9. Correlaçōes entre $\mathrm{K}^{+}$retido por percola ção e outros componentes do solo ..... 152

4.4.10.Considerações gerais .............. 154

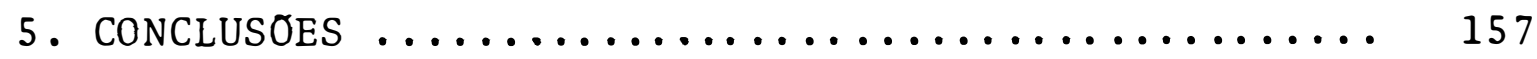

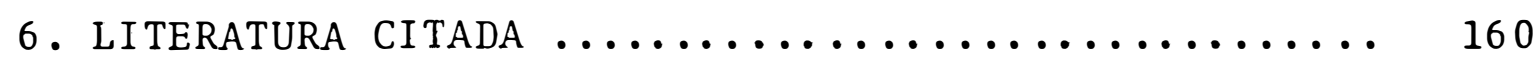

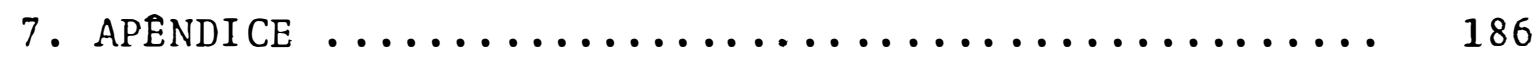


Tabela 1. Principais características físicas do solo utilizado neste trabalho (LEa-2) ........

Tabela 2. Principais características quimicas do ho rizonte Ap, antes da instalação do ensaio (1977)

Tabela 3. Características químicas do basalto altera

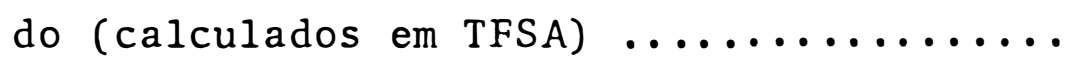

Tabela 4. Precipitação pluviométrica na seção da Usina Barra Grande de Lençóis Paulista,

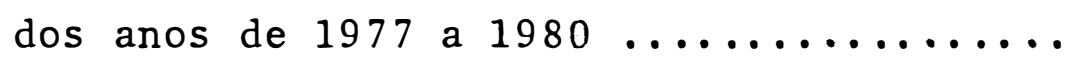

Tabela 5. Valores da capacidade de troca cationica e teores de matéria orgânica do basalto al terado, e do horizonte Ap $(0-25 \mathrm{~cm})$ do solo e dos tratamentos em condiçōes de campo, coletados nos anos de 1978 e 1979 .......

Tabela 6. Teores dos principais elementos químicos no basalto alterado e no horizonte Ap (0$25 \mathrm{~cm}$ ) do solo e dos tratamentos, em condi ções de campo, coletados nos anos de 1978

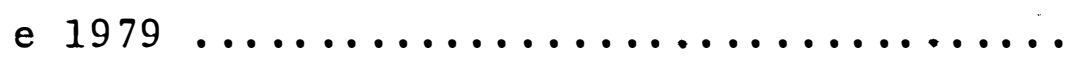

Tabela 7. Determinaçōes analíticas de $\mathrm{pH}$ e pHo e ZPNC das amostras do horizonte Ap dos tra tamentos (mistura das três repetiçōes) nos anos de 1978 é 1979 e do basalto alterado. 
Tabela 8. Média dos teores dos principais elementos químicos, por fator, no horizonte Ap (0$25 \mathrm{~cm}$ ) do solo e dos tratamentos em condições de campo nos anos de 1978 e 1979 ....

Tabela 9. Resultados de $\Delta \mathrm{pH}, \sigma \mathrm{p}$, ov e ot e valores de pHo para os tratamentos e o basalto altera

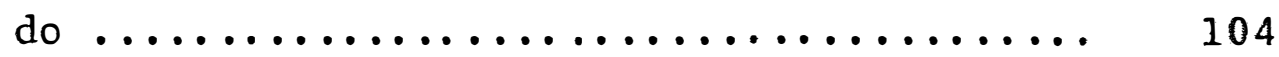

Tabela 10. Resultados da superfície específica, densidade de carga e valores de $K_{a d s}^{+}, \gamma_{a}^{-}, \gamma$ e $\gamma_{c}^{-}$para os tratamentos e para o basalto alterado $\ldots \ldots \ldots \ldots \ldots \ldots \ldots \ldots \ldots \ldots \ldots$

Tabela 11. Valores das relações de atividades, coeficientes de seletividade e relações iônicas entre os íons $\mathrm{Ca}, \mathrm{K}$ e $\mathrm{Mg}$ para os tratamen tos e para o basalto alterado ............

FIGURAS

Figura 1. Perfil geológico da ärea de estudo de alteração em rochas basälticas da Formação Ser ra Geral no município de Botucatu-SP ......

Figura 2. Distribuição geogrāfica das efusivas bāsi cas no sul do Brasil (SCHNEIDER, 1964 e LE MOS , 1976) $\ldots \ldots \ldots \ldots \ldots \ldots \ldots \ldots \ldots \ldots$ 
Figura 3. Localização e projeção da extensão das jazi das de nontronita de alteração de basaltos,

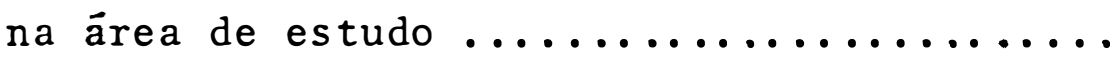

Figura 4. Difratogramas de raios-X da fração argila do basalto alterado

Figura 5. Difratogramas de raios-X da fração argila.

a) das amostras saturadas $\operatorname{com} \mathrm{K}^{+}$; b) argila total, média e fina; c) as amostras satura das com $\mathrm{Mg}$; d) para as camadas 0-25 cm e 25$50 \mathrm{~cm} \mathrm{da} \mathrm{amostra} \mathrm{a}_{3} \ldots \ldots \ldots \ldots \ldots \ldots \ldots \ldots \ldots \ldots \ldots \ldots \ldots$

Figura 6. Curvas de titulação potenciométrica pelo mé todo contínuo na determinação do pHo, para os três níveis de adubação, nos tratamentos sem adição de basalto ....................... 110

Figura 7. Curvas de titulação potenciométrica pelo mé todo contínuo na determinação do pHo para os três níveis de adubação, nos tratamentos com adição de 16 ton/ha de basalto alterado.

Figura 8. Curvas de titulação potenciométrica pelo mé todo contínuo na determinação do pHo para os três níveis de adubação, nos tratamentos com adição de 32 ton/ha de basalto alterado ....

Figura 9. Curvas de titulação potenciométrica pelo mé todo contínuo na determinação do pHo para os três níveis de adubação, nos tratamentos com adição de 48 tơn/ha de basalto alterado .... 
Figura 10. Curvas de titulação potenciométrica pelo mé todo da adição na determinação do pHo, para os três níveis de adubação nos tratamentos, sem adição de basalto alterado ...........

Figura 11. Curvas de titulação potenciométrica pelo mé todo da adição na determinação do pHo, para os três níveis de adubação nos tratamentos com adição de 16 ton/ha de basalto alterado.

Figura 12. Curvas de titulação potenciométrica pelo mé todo da adição na determinação do pHo, para os três níveis de adubação nos tratamentos com adição de 32 ton/ha de basalto alterado.

Figura 13. Curvas de titulação potenciométrica pelo mê todo da adição na determinação do pHo, para os três níveis de adubação nos tratamentos com adição de 48 ton/ha de basalto alterado.

Figura 14. Curvas de titulação potenciométrica pelo mé todo contínuo na determinação do pHo das $\underline{\text { a }}$ mostras atacadas com $\mathrm{H}_{2} \mathrm{O}_{2}$ para destruição da matéria orgânica, nos tratamentos sem adi-

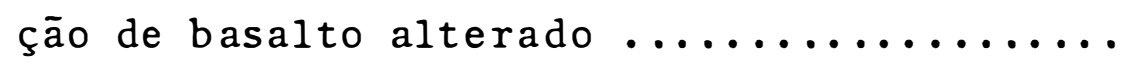

Figura 15. Curvas de titulação potenciométrica pelo mê todo contínuo na determinação do pHo para destruição da matéria orgânica, nos tratamen tos com adição de 16 ton/ha de basalto alterado 
Figura 16. Curvas de titulação potenciométrica pelo mé todo contínuo na determinaçāo do pHo das a mostras atacadas com. $\mathrm{H}_{2}{ }^{0}$ para destruiçāo da matéria orgânica, nos tratamentos com adiçāo de 32 ton/ha de basalto alterado .......

Figura 17. Curvas de titulação potenciométrica pelo mé todo contínuo na determinaçāo do pHo das a mostras atacadas com $\mathrm{H}_{2} \mathrm{O}$ para destruiçāo da matéria orgânića, nos tratamentos com adiçāo

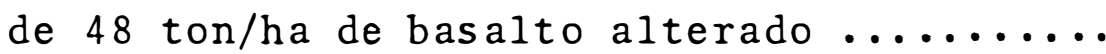

Figura 18. Curvas de titulação potenciométrica pelo mé todo contínuo na determinaçāo do pHo da amos tra $a_{3}$ deferrificada após ataque com $\mathrm{H}_{2} \mathrm{O}$ pa ra destruição da matéria orgânica ........

Figura 19. Ma - Curvas de titulaçāo pelo método contí nuo na determinação do pHo do basalto altera do; $\mathrm{Mb}$ - Curvas de titulaçāo pelo método da adiçāo para determinaçāo do pHo do basalto alterado; Mc - Curvas de adsorçāo de $K^{+}$; e $\mathrm{Cl}^{-}$em funçāo do $\mathrm{pH}$ para o basalto alterado. 125

Figura 20. Curvas de adsorção de $\mathrm{K}^{+}$e $\mathrm{Cl}^{-}$em funçāo do pH para determinaçāo do ZPNC e o das amos tras sem adiçāo de basalto alterado ........

Figura 21. Curvas de adsorção de $\mathrm{K}^{+}$e $\mathrm{Cl}^{-}$em função do pH para determinaçāo do ZPNC e op das amos tras com adição de 16 ton/ha de basalto alte

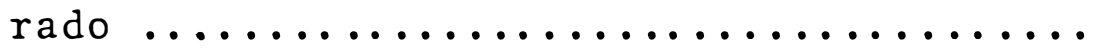


.xiv.

Pag.

Figura 22. Curvas de adsorção de $\mathrm{K}^{+}$e $\mathrm{Cl}^{-}$em função do pH para determinação do ZPNC e op das amos tras com adição de 32 ton/ha de basalto alte

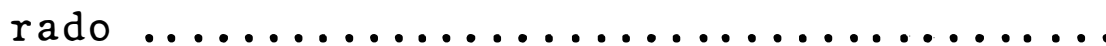

Figura 23. Curvas de adsorção de $\mathrm{K}^{+}$e $\mathrm{Cl}^{-}$em função do pH para determinação do ZPNC e op das amos tras com adição de 48 ton/ha de basalto alte

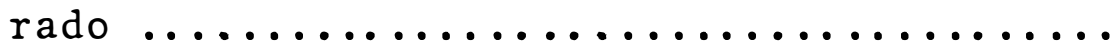

Figura 24. Efeitos dos níveis de basalto alterado ( $a_{0}$, $\left.a_{1}, a_{2} e a_{3}\right)$ e doses de adubação $\left(b_{1}, b_{2} e\right.$ $\mathrm{b}_{3}$ ) na retenção de $\mathrm{K}^{+}$por percolação de solu

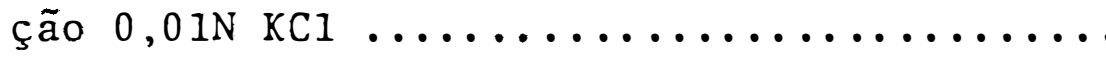

Figura 25. Correlaçōes entre a retenção de $\mathrm{K}^{+}$por perco lação de solução $0,01 \mathrm{~N}$ KCI e os teores de cálcio e matéria orgânica (a) e magnésio

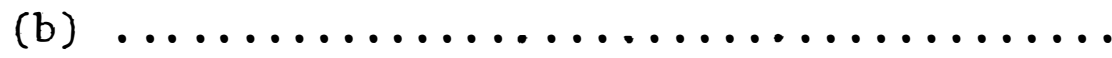


EFEITOS DA APLICAÇÃO DE BASALTO DE ALTERAÇÃO HIDROTERMAL SOBRE AS PROPRIEDADES FISICO-QUTMICAS DE UM LATOSSOLO VERMELHO ESCU RO TEXTURA ARENOSA MEDIA.

\author{
ADEMERCIO ANTONIO PACCOLA \\ Orientador: Antonio Carlos: Teixeira Mendes
}

RESUMO

0 presente trabalho constou de uma primeira par te referente ao estudo de processos de alteração de rochas ba sálticas da formação Serra Geral no município de Botucatu, Es tado de São Paulo. Os resultados revelaram a existência de processos de alteração metassomáticos hidrotermais nas regiões de contato das lavas basālticas com o arenito eólico (cretá ceo) com recristalização de argilas constituídas predominante 
mente por nontronita aparecendo ainda caolinitas desordenadas (fire-clays) e/ou haloisitas, bem como as zeólitas, analcima e estilbita.

O basalto alterado apresenta uma capacidade de troca cationica de $80,04 \mathrm{meq} / 100 \mathrm{~g}$ e a sua ocorrência em gran des jazidas próximas a regiões de solos pobres permite a sua utilização como um agente melhorador de solo.

A aplicação desse material em um solo de baixa fertilidade LEa, promoveu a elevação dos teores de cálcio e magnésio trocáveis, bem como de fósforo solúvel. As relações de atividades sofreram alterações no sentido do solo natural para a maior dose de aplicação de basalto alterado: $\mathrm{RA}_{\mathrm{Mg}}^{\mathrm{Ca}}$ de 6,56 a 4,08, $\mathrm{RA}_{\mathrm{Ca}}^{\mathrm{K}}$ de 0,220 a $0,319, \mathrm{RA}_{\mathrm{Mg}}^{\mathrm{K}}$ de 1,72 a 1,13 e $\mathrm{RA}_{(\mathrm{Ca}+\mathrm{Mg})}^{\mathrm{K}}$ de 0,258 à 0,312 ; as relações iônicas $\mathrm{Mg}^{2+} / \mathrm{Ca}^{2+}$ de 0,20 à 0,$50 ; \mathrm{Ca}^{2+} /$ cations totais de 0,12 a 0,22 ; os coeficien tes de atividades $\mathrm{Kc}_{\mathrm{Mg}}^{\mathrm{K}}$ de 0,33 à $0,09, \mathrm{Kc}_{(\mathrm{Ca}+\mathrm{Mg})}^{\mathrm{K}}$ de 0,45 a 0,16 .

Foram determinadas as superfícies específicas dos tratamentos que variaram de 102,5 a $139,9 \mathrm{~m}^{2} / \mathrm{g}$ calculada pelo método da equação, e 83,9 a $115,0 \mathrm{~m}^{2} / \mathrm{g}$ para a superfície medida pela adsorção de etileno glicol. Para o basalto alterado foram encontrados $559,8 \mathrm{~m}^{2} / \mathrm{g}$ e $618,5 \mathrm{~m}^{2} / \mathrm{g}$ respectivamente. A superfície de carga variável para o solo sem adição de basa 1 to foi de $77,5 \mathrm{~m}^{2} / \mathrm{g}$ em média, enquanto que para a maior dosa gem do produto a média foi de $92,1 \mathrm{~m}^{2} / \mathrm{g}$.

A capacidade de troca cationica do solo elevou- 
se de 3,92 para $7,69 \mathrm{meq} / 100 \mathrm{~g}$ de solo. A matéria orgânica "no solo natural representa aproximadamente $50 \%$ da CTC total do so 10, sendo entretanto, extremamente variável a sua capacidade de troca cationica, oscilando entre 173,8 e 260,4 meq/100g de matéria orgânica. As cargas variáveis neste solo são sempre em maior número que as cargas permanentes, mesmo para os tratamen tos com as maiores dosagens de basalto alterado. No presente trabalho foi proposto um método de determinação das cargas per manentes que apresenta resultados mais coerentes com a capacidade de troca de cátions para o solo em questão. 0 método ba seia-se em valores de $\Delta \mathrm{pH}$ em solos tratados por diálise ácida, através da equação:

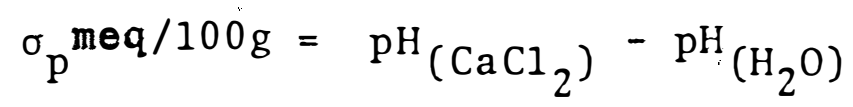

Os valores de pHo para os solos cuja matéria or gânica foi destruída, foram sempre superiores aos corresponden tes com matéria orgânica, mostrando que este componente tende a diminuir os valores de pHo. A deferrificação, por outro la do, promoveu uma elevação do valor de pHo, porém, situando-se em posição intermediária entre o solo natural e aquele em que a matéria orgânica foi destruída. Os óxidos de ferro tendem a elevar os valores de pHo.

Em todos os casos os valores de ZPNC foram sem pre inferiores à pHo indicando a existência predominante de cargas permanentes negativas, que sofreram elevação com a, adi ção de basalto alterado. 
.04 .

As mudanças positivas nas propriedades físicoquímicas dos solos que receberam aplicações de doses crescen tes de basalto alterado, bem como a elevação da fertilidade, permitiram a caracterização desse material como um melhorador de solo. A existência de grandes jazidas, bem como a sua distribuição geográfica próxima as áreas de ocorrência de solos pobres tornam mais promissora a viabilidade econômica de sua utilização. 
.05 .

EFFECT OF A HYDROTHERMAL ALTERATION BASALT APPLICATION ON A DARK-RED-LATOSOLIC SOIL PHYSICAL-CHEMICAL PROPRIETIES.

ADEMERCIO ANTONIO PACCOLA

Orientador: Antonio Carlos Teixeira Mendes

SUMMARY

In the first part of the present work it was studied the weathering process of a basaltic rock founded at Serra Geral area, Botucatu, State of São Paulo. The results have shown a hydrothermal metassomatic weathering process with nontronite clay recrystalization, fire-clays and/or halloysites as well as zeolites: analcime and stilbite. The alterated b salt presented a CTC value of 80.04 meq/100 $\mathrm{g}$, occurring near poor soil areas allowing its use to improve soil properties. The application of this material in a poor LEa soil have in 
creased the exchangeable calcium and magnesium contents and soluble phosphorus. Activity and ionic relationships as well as selectivity coefficients have been changed too. The specific surfaces calculated from the equation method ranged from 102.5 to $139.9 \mathrm{~m}^{2} / \mathrm{g}$. By using the etilene glicol method the values were founded between 83.9 to $115.0 \mathrm{~m}^{2} / \mathrm{g}$. The corresponding values for the weathered basalts were 559.8 and $618.6 \mathrm{~m}^{2} / \mathrm{g}$, respectively. The variable surface charge for soil without basalt addition was $77.5 \mathrm{~m}^{2} / \mathrm{g}$, whereas the average for the largest dose was $92.1 \mathrm{~m}^{2} / \mathrm{g}$. The CTC of the soil increased from 3.92 to $7.69 \mathrm{meq} / 100 \mathrm{~g}$. The organic watter of the natural soil was roughly $50 \%$ of total CTC, varying from 173.8 to 260.4 meq/100 $\mathrm{g}$ of organic matter. Variable charges of the soils were always larger than permanent charges. The present work have shown a permanent charge determination method with good results. The method was based on $\Delta \mathrm{pH}$ values of the soil treated by acid dialysis through the equation:

$$
\sigma_{\mathrm{p}} \mathrm{meq} / 100 \mathrm{~g}=\mathrm{pH}\left(\mathrm{CaCl}_{2}\right)-\mathrm{pH}_{\left(\mathrm{H}_{2} \mathrm{O}\right)}
$$

The determined pHo values for soils with destructed organic matter were always higher than soils with ordinary organic matter content, being observed that this soil component have the tendency to decrease pHo values. The deferrification pro moted a pHo elevation, reaching intermediate levels between natural and destructed organic matter soils. The iron oxides 
tends to increase pHo values. ZPNC values were always lower than pHo, showing negative permanent charge, which increased with the addition of alterated basalt. Favorable alterations on physical-chemical proprieties and the improvement of soil fertility allow to characterize the material as a soil conditioner. Large occurence and strategic geographic distribution can promote an economic utilization of this material. 
As tentativas de busca de produtos e técnicas para melhoria das propriedades dos solos remontam a tempos his tóricos. Foi, porém, em 1840 que Liebig desenvolveu estudos mais científicos, com base em dados analíticos, recomendando o uso de cinzas como fonte de potássio para as plantas.

A aplicação de misturas de adubos em solos que recebem previamente calcáreo pode influenciar as relações en tre os diversos ions adsorvidos e os da solução do solo. Evi dentemente, de acordo com o equilíbrio estabelecido, alguns íns podem ser mais facilmente deslocados do complexo coloidal e, consequentemente, lixiviados com maior facilidade. Este fa to é de real importância para o estudo das doses mais econômi cas de fertilizantes e corretivos a serem empregados nos diver sos solos.

Por outro lado, a absorção de nutrientes pelas plantas também está relacionada com as trocas iônicas nas su perfícies dos colóides do solo. Estes componentes - argilas e 
substâncias orgânicas - por suas propriedades e interações com outros constituintes do solo, representam um parâmetro fundamental que condiciona a boa textura e necessäria estrutura, das quais depende a fertilidade físico-química e estrutural do solo.

O grau de dependência de adsorção de um íon em relação à concentração dos outros íons no solo ainda não está bem definido, pois muitos trabalhos a respeito conduzem, por vezes, a conclusões bastante divergentes.

Acredita-se que a integração entre as diversas áreas do conhecimento das ciências do solo possa fornecer sub sídios valiosos para um melhor equacionamento e compreensão dessas discrepâncias de resultados.

Atualmente, com a expansão das áreas agrícolas têm sido utilizados solos com baixos teores de argila e maté ria orgânica, mesmo para o cultivo de espécies mais exigentes tornando um tanto problemático o exercício da agricultura, pe la falta de uma harmônica e eficiente relação de nutrientes para as plantas. Associada à baixa fertilidade natural desses solos, a distribuição irregular das precipitações pluviométri cas agravam o problema, provocando frequentemente grandes per das de nutrientes por lixiviação, como ainda "stress" hídrico por falta de umidade no solo.

Numa primeira etapa, este trabalho tem a finalidade de verificar a existência de um processo metassomático h drotermal de alteração que atuou sobre rochas básicas da forma 
ção Serra Geral do Estado de São Paulo, a estabelecer a gênese das nontronitas que aparecem nessas condições.

No sentido de contribuir com alguns esclareci mentos sobre as questões anteriormente apresentadas, esta pesquisa tem o objetivo precípuo de verificar o comportamento des se material alterado de rochas basālticas, através de mudanças nas propriedades físico-químicas de um solo de textura arenosa na camada superficial e de baixa fertilidade. 
2. REVISÃO DE LITERATURA

2.1. Geologia e Solos

As primeiras referências que se tem conhecimen to sobre os derrames de lavas basālticas no Brasil pertencem a DERBY (1896) e BRANNER (1896) estudando a decomposição dessas rochas.

HARRISON (1910) deu prosseguimento a essas pes quisas estudando o diabásio e suas crostas de alteração jā ob servando a presença do quartzo nos produtos do intemperismo a companhada de perdas acentuadas em bases e sílica e acúmulo de óxidos de ferro e alumínio.

Estudos sobre a decomposição de basaltos na Ba cia do Paraná foram executados por BAKER (1923) estabelecendo a associação entre o relevo e os solos provenientes dessas ro chas.

MORAES REGO (1930) fazendo a caracterização pe trográfica dos basaltos do Estado de São Paulo identificou o 
plagioclásio cálcico e o piroxenio (augita) como minerais pre dominantes sendo rara a presença de olivina. GUIMARAES (1933) também realizou estudos extensivos sobre rochas básicas do sul do Brasil.

KENNEDY (1933) considera os sills da Bacia do Paraná como basaltos de composição toleítica, ou seja, sem oli vina, ocorrendo como essenciais o piroxenio augito e por vezes a pigeonita, o plagioclásio cálcico é geralmente a labradori ta, associando-se quantidades variáveis de titano-magnetita e, como acessório escasso aparece a apatita e raramente a olivina.

A COMISSAO INTERESTADUAL DA BACIA PARANÁ-URU GUAI (1964) reconhece várias corridas de lavas, separadas por camadas de arenitos inter-trapps, altamente metamorfizados pe 10 contato com as massas efusivas, e muitas vezes arrastados pelas ondas do magma, mascarando o hiato entre os derrames; texturas peculiares como a vítrea, amigdaloidal, macro e micro granular e o sistema de fraturas ou diaclases, caracterizam as diferentes corridas de lavas.

SCHNEIDER (1964) ressalta a ocorrência mais ou menos acentuada de quartzo, mencionando ainda a rara presença do rutilo. Como minerais secundários é comum a ocorrência de zeólitas, quartzo, calcita e clorita. RÜEGG (1975) estima que, além do quartzo, uma certa quantidade de feldspato potássico também está presente em nossos basaltos.

Os estudos sobre alterações hidrotermais sobre andesitos efetuados por BOCKHEIM e BALLARD (1975), encontraram 
a cristobalita na fração silte dos solos e das rochas decompos tas, assim como, DEER et alii (1966) encontraram-na em cavida des e poros das rochas na forma esferoidal também para o ande sito sob alteração hidrotermal.

Para HAWKINS e ROY (1963) a analcima é sintetizada sob alteração hidrotermal de várias rochas ígneas com pre sença de magnésio.

Segundo BOCKHEIM e BALLARD (1975) nesse mesmo tipo de alteração a haloisita hidratada (10 $\AA$ ) também estā pre sente, contudo em pequenas quantidades.

ESPINDOLA (1979) estudando a pedogenese em ā reas basálticas do Estado de São Paulo encontrou a cristobali ta na rocha alterada da região de Jaú, sendo comum também a ocorrência tanto da haloisita como da methaloisita.

MONIZ e JACKSON (1967), estudando a Terra Roxa Estruturada, apresentaram como explicação para a estrutura em blocos deste solo, a hipótese de alteração hidrotermal prévia da rocha básica, conservando a estrutura da rocha original. GALHEGO et alii (1979), em uma topossequência de solos no município de Botucatu também constatou a presença de methahaloisita em todos os perfis estudados.

GALHEGO e ESPINDOLA (1979) encontraram predomi nantemente caolinita e gibbsita no Latossol Roxo derivado do basalto, enquanto que no Litossol do basalto aparecem a caolinita mal cristalizada, a montmorilonita, pequenas quantidades de haloisita e traços de gibbsita. 
EINSELE et alii (1980) demonstram que a intru são de sills de basalto em sedimentos porosos provocam ativida de hidrotermal, resultando alterações metassomāticas com forma ção de dolomita e calcita recristalizadas a altas temperaturas e também recristalização de minerais de argila.

BOCKEIM e BALLARD (1975) estudando solos prove nientes de rochas sob alteração hidrotermal encontraram a mont morilonita e analcima como minerais predominantes.

Segundo KOONS et alii (1980) Co, Mn, Sc, $\mathrm{Zn}$ e em menor extensão Th e U são retidos pelos óxidos de Fe duran te os primeiros estágios de alteração da diabase; Cr também po de ser retido nos estágios finais.

HEIN et alii (1979) constatou a presença de montmorilonita enriquecida de Fe em nódulos manganíferos, e que essas nontronitas continham relativamente abundantes quantidades de $\mathrm{Cu}, \mathrm{Zn}$ e $\mathrm{Mn}$.

HUMPHRIS e THOMPSON (1978) estudaram a mobilida de dos elementos traços durante a alteração hidrotermal de ba saltos e concluiram que $\mathrm{V}, \mathrm{Y}, \mathrm{Zr}$ e Cr parecem não ser afetados por esse tipo de metassomatismo. Ainda, HUMPHRIS e THOMPSON (1978a), observaram que neste processo hä uma perda maior de cálcio enquanto que o magnésio é relativamente mais retido. GUTMANS (1943) e LEINZ (1949) também realizaram estudos extensivos sobre as rochas basálticas do sul do Bra sil.

Estudos sobre a fração argila dos solos do Estą 
do de São Paulo, através da técnica de raios-X foram amplamen te executados por PAIVA NETTO (1949).

A maioria desses estudos sobre os produtos de alteração de tais rochas mencionam a ocorrência de processos de alteracão com formação de caolinita, gibbsita e óxidos de ferro e alumínio. Entretanto, alguns autores como RAW e MATLEY (1943), ALLEN (1948), FRANCO (1952), fazem referencia a ocorrencia localizada de argilas $2: 1$ na alteração de basaltos, sendo mais frequente o aparecimento da nontronita.

SINGER (1967) afirma que a riqueza em bases das rochas basālticas faz com que o primeiro produto de alteração seja a montmorilonita, cuja lixiviação a conduz para a forma ção da caolinita. MILLOT (1964) relata que nas alterações late ríticas hã neoformações transitórias locais com presença de montmorilonita de carāter efêmero.

A nontronita foi identificada pela primeira vez por BERTHIER (1827). Em seguida COLLINS (1877) e NAGELSCHMILT (1938) caracterizaram-se como pertencente ao grupo da montmor $\underline{i}$ lonita ou esmectita. No Projeto de Pesquisa $n^{8} 49$ do American Petroleum Institute (1919), vários autores estudaram mineralogicamente muitos argilo-minerais dentre os quais a nontronita. LAMEB e MARTIN (1955) estudando a composição e as propriedades usuais em engenharia de construção em solos compostos de diferentes argilo-minerais, observaram que um dos solos que continha nontronita apresentava maiores valores para plasticidade, impermeabilidade e compressibilidade. No Brasil 
numerosas são as ocorrências de argilas nontroníticas. Algumas dessas ocorrências são resultantes da alteração de rochas ba sálticas, que se espalham pela bacia dos rios Paraná e Uruguai (LEINS, 1949). Outras são decorrentes de alteração de rochas ultrabásicas ferro-magnesianas ou de tufos vulcânicos.

As nontronitas provenientes de alteração de ba saltos do Brasil tiveram sua presença identificada por LEINZ (1949), PAIVA NETTO (1949), FRANCO (1952), ALMEIDA (1956), RUIZ (1961 e 1962), GUIMARAES (1964), GUIDICINI e CAMPOS (1968), LADEIRA e ALVES DE BRITO (1968) e ZANDONADI (1972).

A ocorrência de argilo-minerais montmoriloniti cos provenientes da decomposição de basaltos foi identificada em outras partes do mundo, como no Hawaii por SHERMAN e UEHARA (1956), na Inglaterra, por SMITH (1959 e 1960), na Ilha de Rhum por RAGG e BALL (1964), na India por SARBADHIKARI e BHA TTACHERJEE (1966) e nos U.S.A. por ALLEN e SCHEID (1946).

SOUZA SANTOS e RUIZ (1962 e 1963) estudaram a composição mineralógica de argilas de cor verde que ocorrem nas rochas basálticas das barragens de Barra Bonita e Bariri, no Estado de São Paulo. Segundo ZANDONADI (1972) até aquela da ta não se conheciam jazidas economicamente exploráveis de nontronitas provenientes da alteração de rochas basálticas.

As nontronitas provenientes de rochas ultrabás cas ferro-magnesianas foram estudadas por HASUI (1969), LACOURT (1934), BARBOSA (1934 e 1936), LEONARDOS (1956), FROES DE ABREU (1960), GUIMARAES (1955 e 1964), ZANDONADI (1972) e PACCOLA $(1980)$. 
Segundo vários autores RAW e MATLEY (1943), ALLEN e SCHIED (1946), ALLEN (1948), FRANCO (1952), SOUZA SAN TOS e RUIZ (1963) a nontronita ocorre em meios confinados, ao nível da rocha, porém sempre relacionada especialmente aos ba saltos vesiculares ou amigdaloidais, juntamente com zeolitas, quartzo e calcita preenchendo as cavidades.

NOVAC e CICEL (1978) estudando a dissolução de smectitas em ácido clorídrico, observou que as nontronitas são muito mais solúveis que as montmorilonitas e, portanto, fornecem mais sílica para a solução.

Em alteração de anfibolitos, PACCOLA (1980) en controu a nontronita proveniente da alteraçāo dos anfibólios enquanto que a montmorilonita-AL e a caolinita eram provenien tes dos feldspatos em ambiente confinado. No mesmo material ve rificou que o cálcio e o magnésio eram os ions mais evacuados do sistema durante o intemperismo, enquanto que o potássio per manecia constante neste processo.

Os derrames superficiais de efusivas encontramse superpostos uns aos outros ou separados por espessuras va riadas de arenito eólico, não ocorrendo, contudo, simultane a mente no mesmo local ALMEIDA (1964).

Os coloides do solo, argilas e substâncias húmi cas em suas quantidades e interações com outros componentes do solo, representam um parâmetro fundamental que condiciona a boa textura e necessária estrutura, das quais depende a fertilidade físico-química do solo ROTINI (1978). 
MALQUORI (1978) fazendo uma revisão das pesqui sas sobre a natureza mineralógica dos colóides dos solos da Itália, mostra a predominância de minerais do grupo da montmorilonita em regiōes de vulcanismo básico, enquanto que a caoli nita, ilita e clorita são mais frequentes em regiões de vulca nismo ácido.

No Brasil e em solos bem drenados das regiões in tertropicais úmidas, um grande número de autores, MOHR e VAN BAREN (1954), COLLIER (1961), MONIZ et alii (1973), ESPINDOLA (1973), QUEIROZ NETTO (1969) e GALHEGO e ESPINDOLA (1975) cons tataram a predominância absoluta da caolinita seguida da gibbsita na fração argila. Associados a esses dois minerais de a gila encontram-se, invariavelmente, quantidades apreciáveis de óxidos de ferro, alumínio e sílica amorfos e cristalinos (LOT TI e RIFFALDI, 1978 ).

GALHEGO e ESPINDOLA (1975) estudando a mineralogia de latossolos do município de Botucatu, encontraram a predominância de caolinita $(7,5 \%)$ seguida da gibbsita $(6,5 \%)$ na fração argila do Latossol Vermelho Escuro fase arenosa. DEMATTE (1974) obteve teores de $1,2 \%$ para os ó xidos de ferro livre, também para o LEa no município de Lençöis Paulista.

2.2. Físico-Química de Solos e de Argilas

PIERI (1977) estudou o melhoramento experimen tal da C.T.C. de solos arenosos do Senegal, através da adição 
de matéria orgânica, de goethita e fosfato monocálcico. Os re sultados mostraram que a adição de goethita mais fosfato foi superior à matéria orgânica para elevação da C.T.C. e, conclu indo afirma que os resultados poderiam ser ainda mais posití vos com a utilização de outros materiais.

Muitas vezes os sítios de adsorção da goethita por fosfato estão bloqueados por grupamentos silanois ( $\mathrm{Si}-\mathrm{OH}_{n}$ ) fortemente fixados sobre as superfícies adsorventes e que não são geradoras de cargas como os ions fosfatos. Assim somente concentrações muito altas de fósforo na solução do solo podem liberar os sítios para a adsorção de fósforo (OBIHARA e RUSSEL, 1972) .

Segundo ALLISON (1973), a textura e em definiti vo a quantidade de colóides minerais é que determinam o nível de equilíbrio da matéria orgânica no solo em sistema de cultí vo.

A aplicação de produtos visando a melhoria das propriedades físicas dos solos tem sido objeto de estudo de vâa rios pesquisadores, WILLIANS et alii (1967), GABRIELS et alii (1973), STEFANSON (1973). A utilização de PVA por PABLOS e SIL VA (1975) revelou efeitos benéficos nas propriedades físicas do solo.

As variações de umidade do solo alteram signifi cativamente as relações ionicas da solução do solo. Especifica mente para $\mathrm{Mg}^{+2} / \mathrm{Ca}^{+2}$ e $\mathrm{Ca}^{+2} /$ cations totais podem produzir con dições adversas para o crescimento de algumas plantas se atin- 
girem valores maiores que 1,0 para ambas, ou caírem abaixo de 0,10 para $\mathrm{Mg}^{+2} / \mathrm{Ca}^{+2}$ e 0,15 para $\mathrm{Ca}^{+2} /$ cations totais(CARTER et alii, 1979) .

CHOPART e NICOU (1976) afirmam que a mecaniza ção do solo modifica de uma certa forma, favoravelmente, todas as características para o enraizamento das plantas. O fenômeno é mais ou menos intenso em função das espécies cultivadas e da qualidade da mecanização, sendo que os efeitos sobre a parte aérea está em relação com este melhoramento do sistema radicu lar e que a parte vegetativa e os rendimentos são aumentados de 20 a $100 \%$ devido a umamelhor absorção de água e minerais.

Trabalhos realizados pelo IRAT (1975) concluí ram que há um efeito muito positivo da matéria orgânica nas propriedades físico-químicas e biológicas dos solos, efeitos esses que se traduzem por aumentos de rendimentos agrícolas e manutenção da fertilidade do solo.

As reações físico-químicas dos solos estão rela cionadas com as propriedades mineralógicas da fração argila e com a matéria orgânica. Nos solos de clima temperado que apre sentam características mineralógicas diferentes dos nossos,tem sido admitida a existência de dois tipos de cargas: a permanen te e a dependente de pH (MCLEAN e. BITTENCOURT, 1974).

Os solos brasileiros por sua vez, apresentam mais frequentemente, a fração argila constituída principalmen te de caolinita, gibbsita e óxidos hidratados de Fe e Al em di ferentes graus de cristalinidade; algumas vezes aparecem vermi 
culita e ilita em pequenas proporçōes (ABRUNA et alii, 1964 ; ESPINDOLA e GALHEGO, 1975).

Os óxidos hidratados, principalmente os amorfos, apresentam propriedades de troca iônica atuando como com ponente importante na C.T.C. dos solos determinando predominan temente cargas dependentes de $\mathrm{pH}$, podendo ser de caráter anfotérico (REEWIJK e VILLIERS, 1968).

Devido a essa alta predominância de cargas de pendentes de $\mathrm{pH}$ em nossas condições, pode-se esperar um compor tamento diferente daquele apresentado pelos solos de clima tem perado com predominância de argilas do tipo $2: 1$, pois segundo MCLEAN (1971) as cargas permanentes apresentam alta afinidade para ions bivalentes, enquanto as dependentes de $\mathrm{pH}$ preferem os ions monovalentes.

Segundo PIERI (1977) a C.T.C. do solo é produzi da por dois fatores, sendo correspondente respectivamente à su perfície específica e a densidade de carga líquida dessa supe fície. Ac teorias básicas sobre as propriedades das superfícies dos colóides do solo foram largamente estudadas por VAN OLPHEN (1962), WIKLANDER (1946, 1948, 1951, 1965, 1970, 1974), JENSEN (1975), UEHARA e GILLMAN (1980), VAN RAIJ e PEECH (1972). O trabalho de PIERI (1976), mostra a eleva ção da capacidade de troca de cations do solo com a aplicação de óxidos de Fe e Fosfatos, bem como preconiza a adição de maté ria orgânica, como agente melhorador dos solos. EDMEADES e JUDD (1980) encontraram também uma elevação da C.T.C. em vä- 
rios solos através da aplicaçāo de calcáreo, ocorrendo, porém, uma consequente alteraçāo nas características de seletividade dos colóides do solo, sendo aumentada a relaçāo $\mathrm{Ks}_{\mathrm{Mg}}^{\mathrm{Ca}}$ e diminuin do a disponibilidade do potássio. Vários autores procuraram tra tar do estudo da lixiviaçãode ions em colunas de solo (BERG e THOMAS, 1959; MARTINI, 1966) e, visando a avaliação da seletiví dade apresentada pelos diferentes colóides do solo, CARSON e DI XON (1972), JENSEN (1975) e RICH (1968) realizaram trabalhos de talhados no assunto.

No Brasil, onde os solos são normalmente ācidos, é usual a aplicaçāo de calcáreo, com a finalidade de se corrigir o $\mathrm{pH}$ e fornecer $\mathrm{Ca}$ e $\mathrm{Mg}$ para os vegetais (IGUE et alii, 1970 ; LEITE et alii, 1970; MASCARENHAS et alii, 1970). Entretan to, alguns estudos mostram que o cálcio tem um efeito significa tivo no deslocamento do potássio, fazendo com que o ion seja lí xiviado com maior facilidade (LEITE et alii, 1970; TELLA et alii, 1970; VERDADE et alii, 1966). Por outro lado, tem-se verí ficado que o cálcio e o magnésio são retidos relativamente com menor energia que o potássio, em solos altamente intemperizados. O conhecimento desses comportamentos iônicos além de mos trarem as condiçōes com que certos cátions são lixiviados, re fletem também aspectos relacionados com a concentração salina da solução do solo, que em muitos casos pode também causar da nos às plantas (IGUE et alii, 1970; MASCARENHAS et alii, 1970; MIYASAKA et alii, 1966).

Segundo HERBILLON et alii (1977) as superfícies 
ativas da fração mineral criadas pelos processos de formação dos solos são classificadas em duas categorias: (i) superfícies de óxidos e hidróxidos de ferro e alumínio que exibem forte afinidade por sílica solúvel, e (ii) superfícies de minerais silicatados que fornecem sílica à solução do solo num processo de in temperismo.

Os colóides inorgânicos não cristalinos do so10, óxidos de ferro, alumínio, manganês e sílica, mesmo em pe quenas quantidades são capazes de explicar uma vasta gama de $\underline{a}$ ção da evolução pedogenética sobre o comportamento físico-quími co do solo e, em ūltima análise sobre a nutrição mineral das plantas (RIFFALDI e LOTTI, 1978).

Os latossolos húmicos altamente intemperizados são normalmente pobres em sílica solúvel e, a aplicação de sili cato de cálcio promoveu aumentos anuais na produção de cana-deaçúcar por um período de seis anos consecutivos (ROSS et alii, 1974 ; GASCHO e ANDREIS, 1974).

A fixação de fosfatos pelos solos pode ser redu zida pela presença de compostos húmicos que formam, tanto com o fosfato como com os colóides do solo complexos estáveis evitando a fixação do fósforo (GAUR, 1969).

Nos solos tropicais, onde a fração argila é constituída predominantemente por caolinita e oxi-hidróxidos de ferro e alumínio a C.T.C. é devida em grande parte pelos constituintes orgânicos do solo (ROLE DE LA MATIERE ORGANIQUE DANS LA FERTILITE DU SOL, s.a., 1975). 
ALEXIADES e JACKSON (1965) usaram a capacidade de troca de cations medida pela quantidade de calcio deslocado por magnésio (C.T.C. Ca/Mg) e a C.T.C. medida pelo K deslocado por $\mathrm{NH}_{4}$ (C.T.C. $\mathrm{K} / \mathrm{NH}_{4}$ ) para calcular os teores de esmectita e vermiculita. A determinação da C.T.C. pelo método do azul de me tileno (HANG e BRINDLEY, 1970; PAIVA NETTO e PACCOLA, 1974) e com $\mathrm{Ca} / \mathrm{Mg}$ e $\mathrm{K} / \mathrm{NH}_{4}$ fez parte dos estudos quantitativos de componentes de argilas realizados por CHU et alii (1977) e CHU e JOHNSON (1979) .

A C.T.C. Ca/Mg e C.T.C. pelo azul de metileno (C.T.C. AM) è quase idêntica para montmorilonita mas difere grandemente para vermiculita onde C.T.C. AM é menor ainda que a C.T.C. $\mathrm{K} / \mathrm{NH}_{4}$ devido à natureza da molécula do azul de metileno que possui $17,0 \times 7,6 \times 3,3 \AA$ (HANG e BRINDLEY, 1970), podendo acomodar-se nas intercamadas da montmorilonita mas não na vermi culita medindo apenas a sua superfície externa (CHU e JOHNSON, 1979). Geis de aluminosílica também diferem grandemente em valo res de C.T.C. com o cation empregado (CHU e JOHNSON, 1979).

As argilas montmoriloníticas apresentam um fenô meno denominado histerese de troca cationica que depende da com posição da fase sólida e do pH do meio. Esta irreversibilidade de deslocamento iônico não estequiométrica envolve os grupos hi dróxilos das argilas e compostos de hidróxidos de alumínio(MAES e CREMERS, 1975).

VAN BLADEL e LAUDELOUT (1967) descrevem em termos práticos que o efeito de histerese é consequência de disper 
são imperfeita de argilas floculadas por cations divalentes, tornando certos sítios de troca inacessíveis.

Vários autores tem se empenhado em determinar a acidez total titulável e acidez trocável de argilas e solos áci dos (COLEMAN et alii, 1964; COLEMAN e THOMAS, 1964; DE VILLIERS e JACKSON, 1967; DE WAN e RICH, 1979).

SCHWERTMANN e JACKSON (1963) e VIOLANTE e VIO LANTE (1973), mostraram que a titulação potenciométrica contí nua permite a determinação quantitativa dos ions hidrogênio e alumínio e, em presença de eletrolitos, é possível distinguirse o alumínio trocável daquele não trocável.

Os complexos Al (OH)x - montmorilonita são muito estáveis, quando uma pequena quantidade de hidróxido de alumínio está presente e o pH se mantém abaixo de 7,0 (HSU, 1968).

As curvas de titulação potenciométrica de HAl-argilas em presença de eletrólitos mostram tres tampōes. 0 primeiro e o segundo são devidos a titulação dos ions $\mathrm{H}_{3} \mathrm{O}^{+}$e Al $\left(\mathrm{H}_{2} 0\right){ }_{6}^{3+}$ (VIOLANTE e VIOLANTE, 1980) e o terceiro tampão, entre pH 5,5 e 8,2, foi atribuído a polímeros básicos de alumínio por SCHWERTMANN e JACKSON (1963 e 1964), e a um complexo alumíniosilicato por SAWHNEY e FRINK (1966). De acordo com MAY este tampão é devido a hidróxilas em arestas quebradas

Recentemente VIOLANTE e VIOLANTE (1973 e 1978) demonstraram que a quantidade deste ácido fraco permanece pratí 
Cusilente constante por um longo tempo após a indução de decompọ sição de argilas por ácido, enquanto que o contínuo aumento des te terceiro tampão durante o envelhecimento. é devido aos polímeros, apenas quando $\mathrm{o} \mathrm{Al}^{+3}$ constitue predominância entre os ions trocáveis.

A acidez titulável total é significantemente in fluenciada pela distribuição do hidróxido de alumínio nos espa ços interlamelares. E possível que com o envelhecimento desses complexos, particularmente os ions alumínios das intercamadas, se tornem muito fixados e, consequentemente não possam ser neutralizados pela titulação. 0 pH da solução externa aumenta até 8,0 sem que o alumínio nas argilas seja rompletamente neutralí zados a $\mathrm{Al}(\mathrm{OH})_{3}$ (SAWHNEY, 1968 e HSU, 1968).

Segundo JACKSON (1963) e HSU e BATES (1964) a cristalizaçāo dos hidróxidos de alumínio diminuem o seu ponto isoelétrico, com consequente perda de cargas positivas. Estes cristais, porém, permanecem distantes das superfícies das argi las, e não influenciam no valor da acidez titulável total (VIo LANTE e VIOLANTE, 1978) .

A capacidade de troca de cations de solos medi da a diferentes valores de $\mathrm{pH}$ aumenta, especialmente no interva 10 de $\mathrm{pH} 5$ a 8 (COLEMAN et alii, 1959; PRATT e BLAIR, 1962; THO MAS, 1960; GESSA et alii, 1978).

Em horizontes superficiais, a presença da maté ria orgânica contribui em parte para o carāter ácido-fraco. Em sub-solos, contudo, são os colóides minerais os responsáveis pe 
la capacidade tampão (COLEMAN e CRAIG, 1967). Em certas condições, os sesquióxidos podem estar associados com a argila e os sitios de troca encontram-se bloqueados a pH baixo e intermedia rio e podem tornarem-se livres com a adição de bases (RICH e OBENSHAIN, 1955) .

Em seus estudos sobre titulação de colóides de solos, DIXIT (1979) concluiu que um Luvisol possuia uma baixa capacidade tampão quando comparado a um Hapludalf, o que possivelmente se devia ao conteúdo mais baixo de alumínio no Luvisol, sendo titulado rapidamente. Em um Tropudalf do Brasil não encontrou o segundo ponto de inflexão das curvas muito nítido, devido a contínua neutralização de Al e Fe, presentes em gran des quantidades. Comparando os métodos de adição e de titulação contínua, encontrou valores de pHomais baixos, com o primeiro método, para os horizontes mais superficiais de um Hapludalf. KINNIBURGH et alii (1975) estudando as propriedades dos hidróxidos de $\mathrm{Fe}$ e Al concluiu que há uma adsorção preferencial, desses geis, por Ca e Sr em relação ao Na, mesmo em concentrações elevadas deste último, sendo que as frações de $\mathrm{Ca}$ e $\mathrm{Sr}$ adsorvidas dependem principalmente do $\mathrm{pH}$.

TARZI e PROTZ (1979) us ando a técnica de microanálise eletrônica obtiveram resultados evidenciando que com a evolução do intemperismo da biotita há um aumento na seletivida de por potássio adsorvido predominantemente nas bordas das partículas de biotita alterada.

De um modo geral a troca de cations em minerais 
de argila segue a ordem da série liotrópica, tanto para ions mo novalentes como para os polivalentes (GIESEKING e JENNY, 1936). COLEMAN e PEECH (1954) estudando a atividade iônica e a pressão osmótica em suspensões de argila observaram que hã uma seletividade na montmorilonita para adsorção dos di versos ions estudados.

$\mathrm{Na}$ India estudos de SINGH et alii (1979) mostra ram que argilas bentoníticas formaram uma barreira subsuperfi cial efetiva para a redução das perdas de água por percolação, resultando em significativos aumentos na produção.

COLEMAN e MEHLICH (1949) observaram que baixas relaçōes troca de cations/troca de anions estão associadas à a 1 tas fixações de fosfatos pelos solos.

Solos preparados por eletrodialise e por tratamento com ácido acético apresentam quantidades diferentes de cations não trocáveis, quando os solos - H são colocados a reagir com H-resina e também com solução de $\mathrm{CaCl}_{2} 0,01 \mathrm{M}$ à $\quad 80^{\circ} \mathrm{C}$ (GHOSH, 1977) .

A absorção de cálcio, potássio e magnésio pela alfafa foi independente do nível de salinidade dos tratamentos; o sódio e o cloreto, ao contrário foram fortemente influencia dos pelas concentraçōes salinas (SHALHEVET e BERNSTEIN, 1968).

LEE e WIDDOWSON (1977), estudando o potáss io en solos derivados de cinzas vulcânicas, constatou a existência de corre lação significativa entre o teor de $\mathrm{K}^{+}$trocāvel e teor de po tássio total o que sugere uma rápida remoção do potássio trocá- 
vel do sistema.

As formas de potássio no solo tem sido examina das por um grande número de trabalhos em termos de quantidade e intensidade, através do uso das relações $\mathrm{K} / \mathrm{Ca}$, na forma $\mathrm{Q} / \mathrm{I}$ (BECKETT, 1964b;BECKETT e NAFADY, 1967 e 1968) .

A maioria dos solos provenientes de cinzas vul cânicas exibem semelhantes quantidades de $K$, contudo, algumas variações entre as formas trocáveis e não-trocáveis são obtidas (LEE e WIDDOWSON, 1977).

Recentemente, a atividade dos ions na soluçãodo solo, a habilidade do solo em manter esta atividade e preferen cialmente as relações de atividade, tem sido consideradas como importantes fatores para avaliação da absorção de nutrientes pelas plantas. A lei das relações de Schofield requer que as condições dos cations, mantidas no interior da dupla camada, não sejam alteradas pelas mudanças na composição da solução do solo. Assim, ${ }^{a} \mathrm{~K} \cdot{ }^{-1 / 2} \mathrm{Ca}$ dependedaquantidade relativa dos dois ions e da densidade de carga das superfícies de troca, mas independe da concentração da solução do solo e nem do teor de umidade do mesmo. Essa lei não pode ser aplicada à duas condi ções bāsicas do solo: (i) em sistemas onde a concentração da solução externa é suficientemente alta, ou a densidade de carga do complexo trocador é muito baixa. Neste caso uma apreciā vel concentração de anions estará no interior da dupla camada; (ii) sistemas onde um dos ions considerados é preso em sítios específicos (NAFADY, 1972) . 
Num sistema em equilíbrio a energia livre molar parcial de um constituinte é constante. Consequentemente para uma argila em equilíbrio com a solução, RT $\ln \left({ }^{a} \mathrm{~K},{ }^{\mathrm{a}} \mathrm{Ca}\right)$ é proporcional a diferença entre a energia livre do $\mathrm{K}^{+} \mathrm{e}$ do $\mathrm{Ca}^{+2}$ ad sorvidos à fase trocadora (JENSEN, 1973b). Para BOLT (1960), tres tipos de interações podem ser distinguidas: interações coulombianas, interações específicas entre ions e colóides e, interação entre os ions, sendo esta última quase sempre negligível.

A inclinação da porção linear das isotermas de adsorção de $\mathrm{K}^{+}$em relação ao $\mathrm{Ca}^{+2}$ tem sido designada como capa cidade de potencial tampāo $(P B C)$ e a intersecção da curva com o eixo das abcissas é referida como a relação de atividade em equilíbrio $A R_{0}^{K}$. Neste ponto a superfície de troca nem perde nem ganha potássio da solução próxima (LEE e WIDDOWSON, 1977). A transformação logarítmica do $A R_{0}^{K}(p K-1 / 2 \mathrm{pCa})$ tem sido corre lacionada com a absorção de potássio pelas plantas em vários trabalhos (ACQUAYE et alii, 1967; ADDISCOT, 1970; BRADFIELD, 1969; GRAHAM e FOX, 1969 e MOSS e COULTER, 1964).

0 potássio trocável não apresenta correlação com o teor de carbono e/ou com a C.T.C. em alguns solos tropi cais estudados por LEE e WIDDOWSON (1977) e segundo BLAKEMORE (1973) o potássio trocável em solos tropicais perde-se tão rapidamente por lixiviação ou é absorvido pelas plantas, que o desenvolvimento de relações com outras formas mais estáveis se ria preconizado.

BOYER (1972) não encontrou respostas, em níveis 
gerais, para $\mathrm{K}^{+}$não trocāvel em solos tropicais considerando, entretanto, que os métodos empregados para sua avaliação não podem ser generalizados.

NAFADY (1972) estudando no Egito, solos frequen temente fertilizados com $K$ e solos não fertilizados, observou que ambos obedecem a lei das relações, e também que Q/I depende da C.T.C. e da extensão de superfície de troca; observou a inda que a secagem do solo ao ar, a fixação de $K$ e a fertiliza ção não afetaram as relações Q/I do solo e, demonstrou que os solos empobrecidos fixam mais $\mathrm{K}^{+} \mathrm{e}$ o cedem em menor quantidade que os solos enriquecidos.

SCHOFIELD e TAYLOR (1955) e BECKETT (1964a, 1965) mostraram que a relação $\mathrm{Ca}^{+2} / \mathrm{Mg}^{+2}$ não tem efeito sobre o equi1íbrio entre $\mathrm{K}^{+}$ou $\mathrm{H}^{+}$e $\left(\mathrm{Ca}^{+2}+\mathrm{Mg}^{+2}\right)$, o que torna conveniente a utilização da combinação de $\left(\mathrm{Ca}^{+2}+\mathrm{Mg}^{+2}\right)$ e tratä-1os como um único ín.

BOLT (1955) estabeleceu que se as forças de $\underline{a}$ tração entre as superfícies de troca e a solução próxima não são específicas os valores da constante de troca de Gapon (Kg) é independente da natureza do cation considerado. Porém se qualquer atração específica se fizer presente, então os valo res de Kg diferirão para os diversos ions envolvidos.

BECKETT e NAFADY (1967) sugeriram que os sítios normais de adsorção de ions $\mathrm{K}^{+}$estão presentes nas superfícies planares das placas de argila e os sitios específicos estão si tuados nos bordos e espaços interlemelares. Devido estes $\mathrm{K}^{+}$- 
.32 .

sítios específicos, as isotermas de troca entre $\mathrm{K}^{+}$e $\left(\mathrm{Ca}^{+2}+\right.$ $\mathrm{Mg}^{+2}$ ), consistem-se de duas partes: (i) uma parte mais elevada $\underline{1}$ near correspondendo a troca não específica e, (ii) uma parte curva mais baixa de troca nos sitios específicos (NAFADY,1972). BECKETT (1964c) mostrou que a parte superior $1 i$. near da curva é descrita pela equação de Gapon e a parte curva inferior, é confirmada pelas equações de Langmir e Gapon mas com um $\mathrm{Kg}$ de maior valor indicando uma afinidade por $\mathrm{K}^{+}$comparado com outros ions como $\mathrm{Ca}^{+2}, \mathrm{Mg}^{+2}$ e $\mathrm{Na}^{+}$. NYE et alii (1961) também encontraram que, em baixas concentrações, o $\mathrm{K}^{+}$é fortemente retido à fase sólida do solo.

No entender de BECKETT e NAFADY (1969) as relações de atividade são mais apropriadas para estabelecer medidas práticas de disponibilidade de um nutriente em particular, quando este encontra-se em deficiência ou próximo a ela, e sua adsorção é controlada principalmente pela quantidade ou poten cial químico do elemento, do que quando está em suprimento ade quado onde sua absorção é limitada por deficiências em outros aspectos como o desenvolvimento radicular, a umidade do solo, etc.

Os decréscimos nos valores de AR (relações de atividades) pela remoção de uma certa quantidade de $\mathrm{K}^{+}$, serão menores em um solo que contém muito potássio lábil do que em outro com pequenas quantidades (NAFADY, 1972).

Em seus estudos sobre as aproximações termodinâa micas de Argensinger, JENSEN (1973a) observou que as constan 
tes termodinâmicas de equilíbrio e os coeficientes individuais de atividade para cations adsorvidos são frequentemente calculados com base em uma simples isoterma de adsorção que nem sem pre é determinada a uma mesma força iônica. Neste mesmo traba tho encontrou diferentes isotermas, utilizando soluções de di ferentes forças iônicas, tanto para caolinita como para montmo rilonita. Contudo os coeficientes de seletividade entre $\mathrm{Ca}^{+2}$ e $\mathrm{K}^{+}$foram semelhantes em todas concentraçōes de soluções, porém diferentes entre os minerais.

NAFADY (1972) encontrou valores semelhantes pa ra adsorção ou dessorção do $\mathrm{K}^{+}$utilizando tres soluçōes de diferentes concentrações e mesmo em distintas relações solo-solu ção.

As cargas das superfícies das partículas de minerais de argila do solo, ou são provenientes dos defeitos no interior de estrutura, e são chamadas cargas permanentes, ou são consequência da adsorção dos ions $\mathrm{H}^{+}$e $\mathrm{OH}^{-}$determinada pe 10 potencial iônico e neste caso chamadas cargas dependentes de pH (UEHARA e GILLMAN, 1980). Segundo DAVIDTZ e SUMNER(1965) muitas cargas nas superfícies dos minerais de argila encontram-se bloqueadas pelo recobrimento com óxidos de ferro que são responsáveis pelo comportamento anômalo dos solos ferralíticos na variação de suas quantidades de cargas positivas e ne gativas quando sofrem deferrificação.

Da mesma forma a matéria orgânica também pode associar-se às partículas coloidais do solo e da sua interação pode resultar variações no balanço de cargas do solo. Tanto as 
cargas devidas aos óxidos de ferro como aquelas pertencentes a matéria orgânica são dependentes de pH (VAN OLFEN, 1962).

JENSEN (1973) distingue dois tipos de cargas no solo e as denominam de coulombianas e não coulombianas, estas tambēm chamadas de específicas. Afirma ainda que as cargas cou lombianas estão sempre presentes, enquanto que as específicas podem ou não existirem no solo.

KAPOOR e GOSWAMI (1978), estudando as cargas permanentes e pH-dependentes na vermiculita dioctaedral, encon traram valores mais elevados para a acidez titulável do que pa ra acidez trocável com $1 \mathrm{~N} \mathrm{NaCl}$. A diferença foi atribuída a cargas pH dependentes não trocáveis. Afirmam também que ions de alumínio na forma básica e na forma octaedral e unidades Si-0-Al expostas nas superfícies laterais dos cristais de argi la devida as terminações das placas tem sido consideradas como componentes pH dependentes da C.T.C.

A acidez extraível por sal não tamponado foi considerada por COLEMAN et alii (1959) e muitos outros autores como cargas permanentes da C.T.C. causadas por trocas isomor fas na estrutura dos silicatos. E, a acidez remanescente após lavagem com sal neutro, tomada como medida das cargas dependen tes de $\mathrm{pH}$.

SCHWERTMAN E JACKSON (1964) observaram tres estágios de efeito tampão, representando os ions $\mathrm{H}^{+}, \mathrm{Al}^{3+}$ e hi droxi-Al, nas curvas de titulação de $\mathrm{pH}$ em montmorilonita e vermiculita. Encontraram também que a maior parte dos ions hi droxi-Al, não podem ser extraídos por sal neutro. 
A acidez trocável que corresponde as cargas de troca isomorfas levou MITRA e KAPOOR (1969) a acreditar que a acidez extraída por sal neutro não tamponado pode ser considerada como medida das cargas permanentes da CTC.

Estudos posteriores de KAPOOR (1972) sugeriram que dependendo do $\mathrm{pH}$ do sistema, a fraça função ácida não tro cável componente das cargas $\mathrm{pH}$ dependente podem ser devidas ao alumínio octaedral exposto ou unidades SiO-Al ambos contendo alguma carga residual nas terminações da estrutura.

E sabido que o hidróxido de alumínio sofre poli merização e que forma intercamadas com argilas (RICH, 1968; SHEN e RICH, 1962; COLEMAN e THOMAS, 1964) não sendo extraível com sal neutro devido a interação de suas cargas: positivas com os sítios de troca das argilas que são assim bloqueadas para a adsorção de outros ions (HSU e RICH, 1960; SCHWERTMANN e JACKSON, 1964). O grau com que estes sítios sãobloqueados depende da quantidade de sesquióxidos livres presentes e também da den sidade de carga das argilas silicatadas; assim a acidez deslocada por sal neutro não pode ser considerada como o valor das cargas de troca isomorfa (KAPOOR e GOSWAMI, 1978).

Os colóides do solo podem ser classificados, do ponto de vista de suas características eletroquímicas, em dois grandes grupos (Van OLFEN, 1962): (i) colóides com cargas elé tricas constante. E o caso das argilas silicatadas onde as car gas provém de substituição isomorfas no interior das unidades cristalogräficas fundamentais que se manifestam na superfície do colóide e são independentes das condições do meio; (ii) co 
lóides de cargas variảveis que possuem características diferen tes. Os sesquióxidos e de um certo modo a caolinita e a maté ria orgânica, são colóides cujas cargas elétricas provém da adsorção de ions à suas superfícies e que lhes determinam o po tencial.

Estas cargas são dependentes da concentração $\underline{\mathrm{e}}$ letrolítica do meio e sob condiçōes naturais os ions $\mathrm{H}^{+} \mathrm{e} \mathrm{OH}^{-}$ estabelecem uma regra essencial e thes determinam o potencial.

Segundo PIERI (1977) a fórmula que exprime a carga por unidade de superfície, ou densidade de carga, para este ūltimo tipo de colóide é:

$$
\Gamma=F\left(\mathrm{\Gamma H}^{+}-\mathrm{\Gamma OH}^{-}\right)
$$

onde:

$$
\begin{aligned}
\Gamma= & \text { densidade de carga. } \\
\mathrm{F}= & \text { constante de Faraday. } \\
\mathrm{\Gamma H}^{+} \text {e } \mathrm{\Gamma OH}^{-}= & \text {quantidade de ions } \mathrm{H}^{+} \text {e } \mathrm{OH}^{-} \text {adsorvidos por } \\
& \text { unidade de superfície. }
\end{aligned}
$$

Por definição o ponto de carga zero (ZPC ou pHo) è obtido por $\sigma=0$ e em valores de $\mathrm{pH}$ por:

$$
\mathrm{ZPC}=\log \frac{1}{\mathrm{H}_{\mathrm{O}}^{+}}
$$

e como normalmente os solos encontram-se como um meio diluído e,uma vez que o potencial de superfície é fraco,a equação pode ser escrita da seguinte forma: 


$$
\sigma=\frac{\mathrm{KE}}{4 \pi} \frac{\mathrm{RT}}{\mathrm{F}} \ln \frac{\mathrm{H}^{+}}{\mathrm{H}_{\mathrm{O}}^{+}}
$$

e através da equação (2) chegamos a:

$$
\sigma=\frac{\mathrm{K} \varepsilon}{4 \pi} \quad 0,059(\mathrm{ZPC}-\mathrm{pH})
$$

onde $K$ é um coeficiente em função da concentração eletrolítica do meio, $\varepsilon$ é a constante dielétrica do meio e pH é o do solo (PIERI , 1977) .

De acordo com VAN RAIJ e PEECH (1972) e UEHARA e GILLMAN (1980a) a equação de Gouy-Chapman para as cargas vä riāveis tem a seguinte forma:

$$
\sigma_{v}=\left(\frac{2 \eta \varepsilon \mathrm{kT}}{\pi}\right)^{1 / 2} \cdot \sinh \frac{z \mathrm{e}}{2 \mathrm{kT}} \psi_{\mathrm{o}}
$$

onde:

$$
\begin{aligned}
& n=\text { concentração da solução em ions } / \mathrm{cm}^{3} . \\
& k=\text { constante de Stefan-Boltzman. } \\
& \psi_{0}=\text { potencial elétrico da superfície. }
\end{aligned}
$$

Para VAN RAIJ e PEECH (1972) esta equação da forma como foi proposta, leva a resultados absurdamente altos para potenciais de superfície elevados. Assim a teoria de Stern da dupla camada representa melhor o fenômeno: $\sigma_{\mathrm{T}}=\sigma_{1}+\sigma_{2}$ sendo:

$$
\sigma_{1}=\frac{N_{1} z e}{1+(N A \partial / M n) \exp -(z e \psi \delta+\phi) / k T}
$$


onde:

$$
\begin{aligned}
z= & \text { valência do ion. } \\
e= & \text { carga do eletron em estat coulomb. } \\
N_{1}= & n^{\circ} \text { de sítios viáveis para adsorção de íons } \\
N_{A}= & \text { número de Avogrado. } \\
\partial= & \text { densidade do solvente. } \\
M= & \text { peso molecular do solvente. } \\
\psi_{\delta}= & \text { potencial elétrico na ligação entre a cama } \\
& \text { da de Stern e camada difusa. } \\
\phi= & \text { termo relativo a energia de adsorção espe- } \\
& \text { cífica de ions pela superfície. } \\
\eta= & \text { concentração da solução em equilíbrio em } \\
& \text { ions/cm }{ }^{3} .
\end{aligned}
$$

A carga na camada difusa $\sigma_{2}$ é dada pela teoria de Gouy e Chapman, mas com referência ao potencial de Stern em vez de potencial de superfície:

$$
\sigma_{2}=(2 \mathrm{n} \varepsilon \mathrm{kT} / \pi)^{1 / 2} \sinh \left(z \mathrm{e} \psi_{\delta}\right) / 2 \mathrm{kT}
$$

Para esses mesmos autores ainda, a carga de su perfície pode também ser dada pela equação abaixo, através de uma condensação:

$$
\sigma=\left(\varepsilon^{\prime} / 4 \pi \delta\right) \cdot\left(\psi_{0}-\psi_{\delta}\right)
$$

onde:

$$
\varepsilon^{\prime}=\text { constante dielétrica média no meio da cama }
$$




$$
\begin{aligned}
& \text { da de Stern. } \\
& \delta=\text { espessura da camada de Stern. }
\end{aligned}
$$

Contudo, alguns problemas inerentes à teoria de Stern advém do fato que $N_{1}, \varepsilon^{\prime}$ e $\delta$ não são conhecidos sendo ne cessārio atribuir-lhes valores aproximados e ajustā-los por observações experimentais.

Entretanto, UEHARA e GILMAN (1980a), obtiveramal gumas transformações da equação original de Gouy e Chapman con siderando que os ions que determinam o potencial são $\mathrm{H}^{+} \mathrm{e} \mathrm{OH}^{-}$, $\phi$ é relacionado à $\mathrm{H}^{+}$pela equação do tipo Nernst através da expressão:

$$
\phi_{0}=\frac{\mathrm{kT}}{\mathrm{e}} \ln \frac{\mathrm{H}^{+}}{\mathrm{H}_{0}^{+}}
$$

onde :

$$
\mathrm{H}_{\mathrm{O}}^{+}=\text {atividade do i on } \mathrm{H}^{+} \text {quando } \phi=0 \text {. }
$$

Assim na ausência de adsorção específica obte mos a seguinte equação para cargas variáveis:

$$
\sigma_{\mathrm{V}}=\left(\frac{2 \mathrm{n \varepsilon k \textrm {T }}}{\pi}\right)^{1 / 2} \sinh 1,15 \mathrm{z}\left(\mathrm{pH}_{\mathrm{o}}-\mathrm{pH}\right)
$$

Para o caso de qualquer eletrólito $1: 1$ e para $\mathrm{pH}$ com valores distantes uma unidade de $\mathrm{pH}_{0}$, sinh $1,15 \mathrm{z}\left(\mathrm{pH}_{\mathrm{o}}-\mathrm{pH}\right)$ $=1,15\left(\mathrm{pH}_{\mathrm{o}}-\mathrm{pH}\right)$ e então a equação pode ser escrita da seguin te forma:

$$
\sigma_{v}=1,67 \times 10^{-6} \mathrm{n}^{1 / 2}\left(\mathrm{pH}_{\mathrm{o}}-\mathrm{pH}\right)
$$


Considerando que a densidade de carga líquida total num sistema mixto (cargas permanentes e dependentes) é:

$$
\sigma t=\sigma_{p}+\sigma_{v}
$$

temos :

$$
\sigma t=\sigma_{p}+1,67 \times 10^{-6} \mathrm{n}^{1 / 2}\left(\mathrm{pH}_{\mathrm{o}}-\mathrm{pH}\right)
$$

0 ponto de carga zero do sistema como um todo ocorre quando $\sigma t=0$ e, então:

$$
\sigma_{p}=-n^{1 / 2} 1,67 \times 10^{-6}\left(\mathrm{pH}_{o}-\mathrm{pH}\right)
$$

Por esta expressão, a uma concentração de ele trólito $\mathrm{n}, \mathrm{o}$ pH é o valor do ponto zero de carga do sistema co mo um todo e pode ser expresso como o ponto de carga líquida igual a zero (ZPNC); e o ponto de carga zero das cargas varia á veis como $\mathrm{pH}_{\mathrm{o}}$. Em termos de $\mathrm{pH}$ :

$$
\mathrm{ZPNC}=\mathrm{pH}_{0}+\frac{\sigma_{\mathrm{p}}}{1,67 \times 10^{-6} \mathrm{n}^{1 / 2}}
$$

Através desta ūltima expressão vemos que $\mathrm{pH}_{\mathrm{o}}$ é uma propriedade intrínsica do sistema, enquanto que ZPNC va ria $\operatorname{com} n$.

Esta teoria é aplicável a qualquer eletrólito a baixas concentraçōes (por ex: 0,01N) e a valores de pH dis tantes uma unidade de $\mathrm{pH}_{\mathrm{o}}$. Desta forma a medida das cargas per manentes em sistemas mixtos pode ser obtida através do ajuste 
do $\mathrm{pH}$ da solução do solo ao valor do $\mathrm{pH}_{\mathrm{o}}$. Neste ponto a carga líquida total ot é igual a carga permanente $\sigma_{p}$. Uma pequena e igual quantidade de ions são adsorvidos nas cargas variáveis e, assim, a quantidade de cargas permanentes é obtida por sub tração dos anions adsorvidos do total de cations adsorvidos (UEHARA e GUILMAN, 1980a).

0 ZPNC pode ser medido pela adsorção de ions em função do $\mathrm{pH}$. Ao ZPNC alguns cations podem ser adsorvidos às cargas variáveis e, então, o total de cations adsorvidos pode ser maior ou igual as cargas permanentes medidas a $\mathrm{pH}_{\mathrm{o}}$. A equa ção (15) diz que ZPNC move-se em direção ao $\mathrm{pH}_{0}$ com o aumento da concentração de eletrólitos e é menor que $\mathrm{pH}_{\mathrm{o}}$ quando $\sigma_{\mathrm{p}}$ é negativa, igual a $\mathrm{pH}_{\mathrm{o}}$ se $\sigma_{\mathrm{p}}=0$ e maior que $\mathrm{pH}_{\mathrm{o}}$ se $\sigma_{\mathrm{p}}$ for posi tiva (UEHARA e GUILMAN, 1980a).

A superfície específica pode ser estimada atra vês da adsorção negativa usando a teoria de Gouy-Chapman pela expressão:

$$
\frac{\Gamma^{-}}{N}=\frac{q}{(z \beta N)^{1 / 2}}-\frac{4}{z \beta \Gamma}
$$

onde:

$$
\begin{aligned}
& \Gamma^{-}=\text {adsorção negativa meq } / \mathrm{cm}^{2} . \\
& \left.N=\text { normalidade da solução interna (meq/ } \mathrm{cm}^{3}\right) \\
& z=\text { valência do ion adsorvido. } \\
& q=\text { fator de valência. } \\
& B=1,06 \times 10^{15}(\mathrm{~cm} / \mathrm{meq}) . \\
& \left.\Gamma=\text { densidade de carga total (meq/ } \mathrm{cm}^{2}\right)
\end{aligned}
$$


Se $\mathrm{I}^{-}$for dado em meq/g, a inclinação da curva de $\frac{\Gamma^{-}}{N}$ versus $\frac{q}{(2 \beta N)} I 7 \overline{2}$ dả a superfície específica em $\mathrm{cm}^{2} / \mathrm{g}$. Se $\sigma_{p}$ é negativa, $\sigma_{t}$ aproxima-se de $\Gamma$ quando $o$ pH é 3 ou 4 uni dades acima de $\mathrm{pH}_{0}$. BARBER e ROWELL(1972) expressaram $\Gamma^{-}$e $\Gamma$ em meq/100 g e assim a equação se torna:

$$
\gamma_{\mathrm{a}}^{-}=\frac{\mathrm{qNS}}{(z \beta N)^{1 / 2}}-\frac{4 N S^{2}}{z \beta \gamma}
$$

onde:

$$
\begin{aligned}
& \gamma_{a}^{-}=\mathrm{Sr}^{-} \\
& \gamma^{-}=\mathrm{S} \Gamma \\
& \mathrm{S}=\text { superfície específica } \mathrm{cm}^{2} / 100 \mathrm{~g}
\end{aligned}
$$

De acordo com a mesma teoria ainda a superfície específica de cargas variáveis ( $\mathrm{Sv}$ ) para $25^{\circ} \mathrm{C}$ e com $\left(\mathrm{pH}_{\mathrm{o}}-\mathrm{pH}\right)=2$ em eletrolito $1: 1$ e $0,01 \mathrm{M}$ é:

$$
\mathrm{Sv}=1,83 \times 10^{2} \gamma_{\mathrm{c}}^{-} \mathrm{m}^{2} / \mathrm{g}
$$

sendo:

$$
\gamma_{c}^{-}=\text {adsorção negativa de cations. }
$$

Os solos com elevados teores de gibbsita e óxi dos de ferro livre possuem elevados valores de ZPC (VAN RAIJ e PEECH, 1972; PARKS, 1965), enquanto que minerais com cargas ne gativas permanentes estruturais, tanto quanto a matéria orgâni ca tendem a diminuir os valores de ZPC, podendo mesmo ser uma indicação do conteúdo desses elementos no solo (PARKS e BRUYN, 
1962) .

No caso da presença predominante de argilas com cargas negativas permanentes, O ZPC pode ser muito baixo ou mesmo não existir (VAN RAIJ e PEECK, 1972). Segundo, ainda, es ses mesmos autores, os valores de $\Delta \mathrm{pH}$ dão uma indicação da po sição do ZPC em relação ao $\mathrm{pH}$ do solo. Se $\Delta \mathrm{pH}$ for positivo, o $\mathrm{pH}$ do solo está do lado positivo do ZPC, e o solo possui uma carga líquida positiva. Entretanto se $\Delta \mathrm{pH}$ for negativo, $\mathrm{p} p H$ do solo situa-se no lado negativo do ZPC e, quanto maior o va lor de $|\Delta \mathrm{pH}|$ maior a distância entre o pH do solo e ZPC. BERUBE et alii (1967) e BLOK e BRUYN (1970) a firmam que dentre os fatores que podem afetar as determinações das cargas de superfície, estão o tempo de contacto da amostra com o eletrolito e $\mathrm{A} \mathrm{Al}^{+3}$ trocável que interfere no valor do ZPC. E que, a teoria da dupla camada para uma superfície rever sível não é aplicável quando uma alta proporção da carga de su perfície é devida a cargas permanentes estruturais.

Frequentemente, apenas o pH tem sido considera do responsável pelas variações nas cargas elétricas e na capacidade de troca iônica do solo (SCHOFIELD, 1949). As chamadas cargas dependentes de $\mathrm{pH}$, são também dependentes da valência e concentração do ion considerado, como previsto pela teoria e demonstrado por VAN RAIJ e PEECH (1972). Este fato tem importantes consequências na determinação da C.T.C. e nas cargas pọ sitivas e negativas do solo, e portanto os métodos de determinação comumente usados, são mais adequados à condições onde 
predominam as cargas permanentes, não se aplicando apropriada mente aos solos tropicais cujas cargas são preponderantemente dependentes de $\mathrm{pH}$.

No Senegal, SIBAND (1972) constatou, seguindo a evolução do solo sob cultura tradicional, que a C.T.C. diminui rapidamente após o cultivo e que, nesta fase, ela é mais liga da aos colóides orgânicos que argilosos. Fato semelhante foi observado por CABANETTES e LE BUANEC (1974) em solos ferralíti cos de Côtre d'Ivoire, com alta correlação entre a C.T.C. e teor de carbono. PICHOT (1971); ARRIUETEZ (1974) e VELLY(1974) também chegaram aos mesmos resultados.

MATTSON (1974) observou que hä também uma in fluência bastante significativa das relações aniônicas do solo na capacidade de absorção de nutrientes aniônicos pelas plan tas. Observou ainda grandes diferenças na habilidade de absorção aniônica entre diferentes tipos de plantas e, se um aumen to na atividade da membrana favorece a absorção de cátions di valentes, comparada a de um cátion monovalente, em condições de campo com altas relações $c^{+2} / c^{+}$, a teoria demanda que a absorção de um anion divalente deveria sofrer uma grande supressão em relação a um anion monovalente, mantendo-se uma ba xa relação $a^{-2} / a^{-}$.

As variações das cargas de superfície exercem importantes efeitos sobre o comportamento dos ions em solos a 1 tamente intemperizados, os quais contēm essencialmente caolini ta, sesquióxidos: e humus. Quando o pH do solo aumenta, há um 
incremento nas cargas negativas e ao conträrio a diminuição do $\mathrm{pH}$, promove um decréscimo nas cargas negativas, entretanto, com a diluição da concentração de eletrólitos na solução do so 10, ambas cargas negativas e positivas sofrem diminuição (BRE ENWSMA e LY KLEMA, 1973; EL SWAIFY e SAYEGH, 1976) •

As deficiências de câlcio são frequentemente corrigidas com calcáreo que no entanto mantém a solução do so 10 com baixos níveis de $\mathrm{Ca}^{+2}$ (MUNNS e FOX, 1977a). Este tampona mento de $\mathrm{Ca}^{+2}$ à baixos níveis, pode ser apenas parcialmente ex plicado pelas considerações sobre equilíbrio de troca cationi ca e sítios de afinidades de absorção por $\mathrm{Ca}^{+2}$ (MUNNS, 1976).

A concentração de $\mathrm{Ca}^{+2}$ em extratos aquosos va ria pouco com a diluição (BRENES e PEARSON, 1973; PRATT e BAIR, 1962). Este aparente tampão de $\mathrm{Ca}^{+2}$ contra o efeito de diluição, não pode, também, ser explicado apenas em termos de troca de cations. Com a aplicação de calcáreo a CTC do solo aumentou quase tres vezes, enquanto o pH do solo aumento de 4,8 para 7,1 . Estas cargas adicionais, sendo quase exatamente equivalen te a quantidade de $\mathrm{Ca} \mathrm{CO}_{3}$ reagido, ajudou a manter $\circ \mathrm{Ca}^{+2}$ da solução em baixas concentrações (MUNNS e FOX, 1977a).

A CTC adicional é ocupada por $\mathrm{Ca}^{+2}$, estando par te desse cálcio trocável em uma forma fracamente adsorvida, e facilmente deslocada por KCl diluído (MUNNS, 1976). Tanto es ta fração como o cálcio em solução aumentaram muito pouco com a variação do $\mathrm{pH}$ de 4,8 para 5,8 em um oxisol de textura fina estudado por MUNNS e FOX (1977a) mas aumentou significativamen 
te de 5,8 a 7,1 .

Estes resultados concordam em parte com as evi dências de que o $\mathrm{Ca}^{+2}$ é fracamente retido contra deslocamento por hidrólise dos sítios das cargas pH dependentes nas argilas silicatadas (BAWEJA e MCLEAN, 1975). Contudo, os sítios de car ga do humus são provavelmente importantes nos oxissolos, e a gum $\mathrm{Ca}^{+2}$ nas cargas $\mathrm{pH}$-dependentes é evidentemente preso forte mente (MUNNS, 1976).

A força iônica da solução tem efeito na CTC, sendo aumentada através de relação diretamente proporcional a $\mu$ (BREUWSMA e LYKEMA, 1973; EL SWAIFY e SAYEGH, 1975; GALLEZ e HERBILLON, 1976; MORAIS et alii, 1976).

A excessão do $\mathrm{Na}$, a diminuição do teor de água do solo $(\theta)$ não é acompanhada pelo aumento da concentração iô nica, na solução, como se poderia esperar. 0 pequeno aumento da concentração da solução com o decréscimo de $\theta$, acarreta uma di minuição no conteúdo total em solução por grama de solo. Este tamponamento contra a diminuição de $\theta$, não pode ser devida a precipitação e por outro lado o incremento na adsorção de $\mathrm{Ca}^{+2}$, $\mathrm{Mg}^{+2} \mathrm{e} \mathrm{K}^{+}$implica em aumento de CTC com a diminuição de $\theta$ (MUNNS e FOX, 1977a).

As variações da CTC requer mudanças estequiomé tricas na solução e na interface com os colóides. As altera çōes no pH representam quantidades de hidrogênio livre na solu ção, que são negligíveis em comparação com as mudanças nas con centrações de outros cātions e na CTC (MUNNS e FOX, 1977a). 
Os processos de associação e dissociação de ãcí dos fracos na solução e variações na capacidade de troca iônica, podem ajudar a estabelecer a estequiometria quando a CTC aumenta com $\mathrm{o}$ aumento do $\mathrm{pH}$ ou decréscimo de $\theta$ (BREENWSMA e LYKLEMA, 1973; GALLEZ et alii, 1976; MORAIS et alii, 1976).

A calagem aumenta a CTC por causar um desloca mento de protons da superfície que reagem com o carbonato para produzir $\mathrm{CO}_{2}$ e $\mathrm{H}_{2} \mathrm{O}$. O incremento em bicarbonato é da ordem de $2:$ do aumento de $\mathrm{Ca}^{+2}$ na solução no equilíbrio com a atmosfé ra. Anions de ácidos orgânicos solúveis poderiam também aumentar com 0 pH, mas, nem o bicarbonato nem anions orgânicos po deriam ser muito abundantes uma vez que a atividade microbiológ ca era pequena no caso estudado (MUNNS e FOX, 1977b).

Por outro lado, a calagem pode promover dessor ção de grandes quantidades de anions, uma vez que a CTA em só los altamente intemperizados pode decrescer marcadamente com o aumento do $\mathrm{pH}$ de 4 a 7 (EL-SWAIFY e SAYEGH, 1975; GALLEZ et alii, 1976; MORAIS et alii, 1976).

Quando $\theta$ aumenta, o incremento em bicarbonato e anions orgânicos dissociados estão outra vez, provavelmente,em menor quantidade que a variação da CTC, mas quantidades significativas de anions adsorvidos, podem ter sido deslocados deví do ao abaixamento da concentração salina, que provoca uma dimi nuição tanto na CTC como na CTA. Essas considerações necessí tam ser apreciadas como neutralização simultanea de uma carga negativa por adsorção de um proton e neutralização de uma car 
ga positiva por um $\mathrm{OH}^{-}$, resultando em dessorção de sal e peque na mudança no pH (MUNNS e FOX, 1977b).

Os resultados obtidos por MUNNS e FOX

para oxissolo sugerem que a anālise de $\mathrm{Ca}^{+2}$ em extrato à sa turaçāo pode ser um teste ütil para fertilidade, com erro de aproximaçāo menor que $30 \%$ em relação as condiçōes de campo. Es ta correspondência nāo é usual em solos ácidos (BRENES e PEARSON, 1973; EATON et alii, 1960), e necessita de correlaçōes en tre $\mathrm{Ca}^{+2}$ extraído à saturaçāo e crescimento da planta (MUNNS e FOX, $1977 b)$.

A correção da deficiência de cálcio requer pou co calcāreo em alguns solos (MUNNS, 1976). Contudo em alguns tipos de solos, plantas sensíveis à cálcio podem necessitar grandes quantidades de calcáreo, para corrigir a deficiência desse elemento, mais do que o suficiente para corrigir a aci dez e/ou toxidez de alumínio e manganês. Nestes casos a solução agronômica é a escolha de plantas pouco exigentes em cá1 cio, ou então usar calcāreo para a correçāo da acidez e suplementar cálcio por sal neutro. Estas sugestōes concordam com ex periências práticas no Hawaii onde o gesso tem sido recomenda do como suprimento desse elemento (AYRES, 1961).

De acordo com McBRIDE (1979) a forma de equação para troca iônica baseada na ação de massa pressupōe condiçōes que nāo são válidas para todas as reaçōes de troca. Assim as variaçōes de seletividade dependentes da composiçāo do trocador pode ser aplicada em termos da natureza dos ions hidrata 
dos localizados em sítios específicos. O conhecimento da natureza química dos sítios de troca e dos cátions adsorvidos per mitem a formulação de equações mais precisas para descrever o equilíbrio entre ions e trocador.

A despeito das várias aproximaçōes para as equa ções de troca iônica, os coeficientes de seletividade para $\underline{I}$ ons em colóides são variáveis com a composição iônica do trocą dor (MARSHAL, 1964) tanto quanto com a força iônica da solução (LAUDELOUT et alii, 1968).

Em geral as formas das equações de troca basea das na ação de massa são usadas para calcular os valores do co eficiente de seletividade, mas outros tipos de equações tem sí do encontradas para se obter coeficientes mais constantes para troca entre íons divalentes e monovalentes (ERIKSON, 1952; KRISHNAMOORTH E OVERSTREET, 1949) .

MCBRIDE (1979) propos modificações nas equações de ação de massa, baseado no fato de que íons adsorvidos não são como solução, em todos os aspectos, e que suas "atividades" não são simples funções de fraçōes molares ou equivalen tes desses ions no trocador. Sua equação tem a forma:

$$
\mathrm{K}_{\mathrm{c}}=\frac{\left[\overline{\mathrm{K}^{+}}\right]}{\left[\overline{\mathrm{Na}^{+}}\right]} \cdot \frac{\left(\mathrm{Na}^{+}\right)}{\left(\mathrm{K}^{+}\right)}
$$

onde :

$\left[\overline{\mathrm{K}^{+}}\right]$e $\left[\overline{\mathrm{Na}^{+}}\right]=$fraçōes equivalentes dos sítios de troca da argila ocupados por $\mathrm{K}^{+}$e $\mathrm{Na}^{+}$respectivamente 
e, $\left(\mathrm{K}^{+}\right)$e $\left(\mathrm{Na}^{+}\right)$as atividades das soluçōes no equilíbrio.

Os resultados obtidos, nesse mesmo trabalho, pa ra os coeficientes entre $\mathrm{K}^{+}$e $\mathrm{Na}^{+}$com montmorilonita, mostram a natureza não constante da seletividade por $\mathrm{K}^{+}$, decrescendo com o aumento da quantidade de $\mathrm{K}^{+}$adsorvido na argila.

Com relação ao magnésio CHRISTENSON e DOLL (1978), observaram através de cultivo intensivo em solos areno sos, que a sua absorção não está relacionada com o teor de $\mathrm{Mg}^{2+}$ trocável e nem com o teor total, mas sim, com a compos $\underline{i}$ ção mineralógica da fração argila média em alguns solos arenosos de Michigan. RICE e KAMPRATH (1968), LONGSTAFF e GRAHAN (1951) e SALMON e ARNOLD (1963) encontraram que uma boa quanti dade de $\mathrm{Mg}^{2+}$ não trocável é disponível para as plantas em vâa rios tipos de solos.

GALINDO e BINGHAM (1977) estudando o equilíbrio iônico em solos com cargas variáveis, obtiveram resultados que mostram a adsorção preferencial de $\mathrm{K}^{+}$em relação ao $\mathrm{Na}^{+}$e do $\mathrm{Ca}^{+2}$ em relação a $\mathrm{Mg}^{+2}$. O incremento na densidade de carga a través da adsorção de fosfato resultou em uma redução da seletividade por $\mathrm{K}^{+}$, e aparentemente nenhum efeito entre $\mathrm{Ca}^{+2}$ e $\mathrm{Mg}^{+2}$. Em sistemas heterovalentes estes solos mostraram adsor ção preferencial por cations divalentes, havendo aumentos des ta seletividade com a adsorção de fosfatos.

GESSA (1970), HANSAKER e PRATT (1971) concluí ram que solos com carga pH-dependentes, constituídos principa mente por alofanas adsorvem preferencialmente cations divalen- 
tes em relação aos monovalentes.

Aumentos significativos na CTC dos solos foram obtidos por MEKARU e UEHARA (1972), SCHALCHA et alii, (1972 e 1974) e GALINDO e BINGHAN (1977) através da adsorção de fosfa to, porém com alterações na seletividade dos sítios de troca, semelhantemente aos efeitos de aumento do $\mathrm{pH}$.

MATTSON e LARSSON (1946) afirmaram, com base na distribuição de DONNAN, que a caolinita possui energia de liga ção mais forte por ions monovalentes que por cations divalen tes, sendo portanto um competidor por $K$ mais forte que a bento nita.

Os estudos de ELGabaly e WIKLANDER (1949) mos tram que plantas de trigo absorvem mais $\mathrm{Ca}^{+2}$ e menos $\mathrm{Na}^{+}$de solos com baixa CTC constituídos de caolinita, do que em altas CTC com bentonita. BROWN e NOGGLE (1955) observaram que raízes de soja absorvem mais $\mathrm{K}^{+}$do que $\mathrm{Ca}^{+2}$ da argila montmorilonita do que da caolinita.

MCLEAN e MARSHALL (1948) obtiveram resultados indicando que a adição de $\mathrm{Ca}^{+2}$ em sistemas $\mathrm{K}-\mathrm{H}$-montmorilonita, pode aumentar a disponibilidade de $\mathrm{K}^{+}$para as raízes.

MAES e CRAMERS (1977 e 1978) mostraram que a troca iônica é muito dependente da densidade de carga, tanto pa ra sistemas homovalentes como heterovalentes. Entretanto, con siderando que o valor da CTC em argila $2: 1$ é, em parte, dependente do $\mathrm{pH}$ e do cation índice, a densidade de carga assume va lores variáveis (PIGNEUR et alii, 1975). 
Segundo MAES et alii (1979) os sítios de cargas dependentes de $\mathrm{pH}$ em esmectitas varia de 10 a 20 emg/100g, e certos cations orgânicos como o alquilamonio pode complexarse às intercamadas desses minerais reduzindo a CTC, e ainda para GLAESER et alii (1972) pequenas quantidades de óxidos de alumínio que são precipitadas podem obscurecer os resultados das cargas de troca isomorfas obtidos a partir do cálculo de células unitārias.

A retrogradação do potássio retarda a lixivia ção e prepara as reservas de $\mathrm{K}^{+}$trocáveis do solo. E um fenôme no, cuja intensidade depende da quantidade e da natureza das argilas presentes no solo (DOWDY e HUTCHESON, 1963; BLANCHET et alii, 1965; BRADY, 1974) como também da umidade do solo (DE MUMBRUM e HOOVER, 1958, BLANCHET et alii, 1965; DUCHAUFOUR, 1970), mostraram que a retrogradação do $\mathrm{K}^{+}$é mais acentuada em solos ricos em ilitas. MIELNICZUK (1978) afirma que solos com $\mathrm{pH}$ inferior a 5,5 apresentam muitas cargas ocupadas por $\mathrm{Al}^{+3}$ ou obstruídas por hidróxidos de alumínio e que, embora $0 \mathrm{Al}^{+3}$ possa ser substituído por outros ions, essa troca tem pouca probabilidade de ocorrer em concentrações normais de cations existentes no solo devido a grande força de adsorção do ion $\mathrm{Al}^{+3}$. Nesse mesmo trabalho, o autor comenta que a montmoriloni ta com maior substituição isomorfa na camada octaédrica por $\mathrm{Mg}$ e $\mathrm{Fe})$, apresenta menor carga de superfície, não ocorrendo a diminuição do espaçamento basal por saturação com $\mathrm{K}^{+}$. Entretanto, em algumas montmorilonitas pode haver substituição 
isomorfa tetaédrica (Si por Al) dando origem a montmorilonita de alta carga e que apresentam redução do espaçamento basal por saturação com $\mathrm{K}^{+}$, mesmo sem haver secamento.

A seletividade da ilita, vermiculita e esmecti ta de alta carga, sob condições comparáveis, aumenta sempre no sentido do aumento de densidade de carga que, por sua vez, é mais dependente da espécie mineral do que do tamanho das par tículas. O coeficiente de seletividade aumenta com a concentra ção da solução externa e com o teor de cations de metais pesa dos ligados às argilas (BERGSETH, 1980) .

Segundo o IPI (1977) o potássio trocável determinado pela análise de solo, não dá informações satisfatórias sobre o nível de potássio prontamente disponível, a menos que relacionado ao teor e o tipo de mineral de argila. Os solos mais argilosos necessitam de teores mais altos de potássio de terminado para fornecer a mesma quantidade de $\mathrm{K}^{+}$as plantas que um solo arenoso. Entretanto os solos argilosos mantém uma mesma concentração de $\mathrm{K}^{+}$na solução por um tempo longo, enquan to que em solos arenosos essa concentração decresce rapidamen te.

GREWAL e SINGH (1979) mostraram que os métodosde extração de $\mathrm{K}^{+}$diferem grandemente entre si e de solo para so 1o, concluindo que os níveis críticos para uma determinada cul tura, variam com o método empregado e com o tipo de solo.

De acordo com MIELNICZUK (1978) os argilo-mine rais que apresentam o fenômeno da fixação de potássio são em 
.54 .

ordem decrescente a vermiculita de alta carga, vermiculita de baixa carga e a montmorilonita de alta carga. A montmorilonita de baixa carga não apresenta o fenômeno por possuírem substí tuição isomorfa apenas nas camadas octaédricas. Em uma mesma partícula, entretanto, podem aparecer zonas com característi cas semelhantes a qualquer um dos minerais citados.

BOYER (1973) faz referencia a variação do potás sio trocável com o tempo de cultivo, encontrando valores variá veis para a redução do teor desse nutriente em função da textu ra,da mineralogia, da fertilidade do solo e do tipo de cultu ra utilizada. 
3. MATERIAIS E METODOS

Este trabalho constou inicialmente de uma parte experimental, através de um ensaio de campo incluindo-se a adi ção de quatro doses de basalto alterado, como melhorador do so 10, para elevar a sua CTC até próximo ao dobro do valor inicial. Associou-se também doses de adubação NPK equivalentes à $60 \%, 80 \%$ e $100 \%$ das doses normalmente utilizadas. 0 experimen to foi mantido sob vegetação de cana-de-açúcar (Saccarum $066 \underline{i}$ cinarum) variedade NA-159.

3.1. Localização e Tempo de Duração do Ensaio

O ensaio foi realizado em ärea da Usina Barra Grande no município de Lençóis Paulista-SP. Foi instalado em março de 1977 e conduzido até setembro de 1980 tendo-se colhí do amostras para análises dos solos em 1978 e 1979. 
.56 .

3.2. Solo

Foi classificado por DEMATTE (1974) como Latos sol Vermelho Escuro distrófico, teor de argila entre entre 12$20 \%$, denominado unidade LEa-2. Esta unidade de mapeamento a de maior ocorrência nas terras da Usina, é constituída por solos com horizonte B latossólico (Bsq), argila de atividade baixa (baixa CTC), muito profundo, textura arenosa, bem drenado a acentuadamente drenados, acidez elevada e fertilidade baixa, coloração pardo a vermelho, (Tabela 2).

0 material de origem deste solo é o produto da decomposição de sedimentos arenosos remanejados em período re cente. (Pleistoceno).

0 horizonte superficial é de cor pardo averme1hado escuro, de teor de argila em torno de 12: (Tabela 1), mui to friável, de boa permeabilidade, de éstrutura maciça, pouco coesa formando agregados pouco estáveis, fracamente desenvolvi da e de fraca resistência a erosão.

Logo abaixo do horizonte Ap, ocorre um horizon te de transição $A / B$ de pequena espessura em torno de $20 \mathrm{~cm}$, mais argiloso ( 15 a $18 \%$ de argila), pouco denso e de baixa per meabilidade .

Seguindo-se a este horizonte ocorre o B latossó lico (Bsq) de cor pardo avermelhado, profundo com teores de ar gila variando entre 15 e $20 \%$, muito friável, poroso e de boa permeabilidade. O relevo é plano a suavemente ondulado.

Por se tratar de um solo essencialmente areno- 


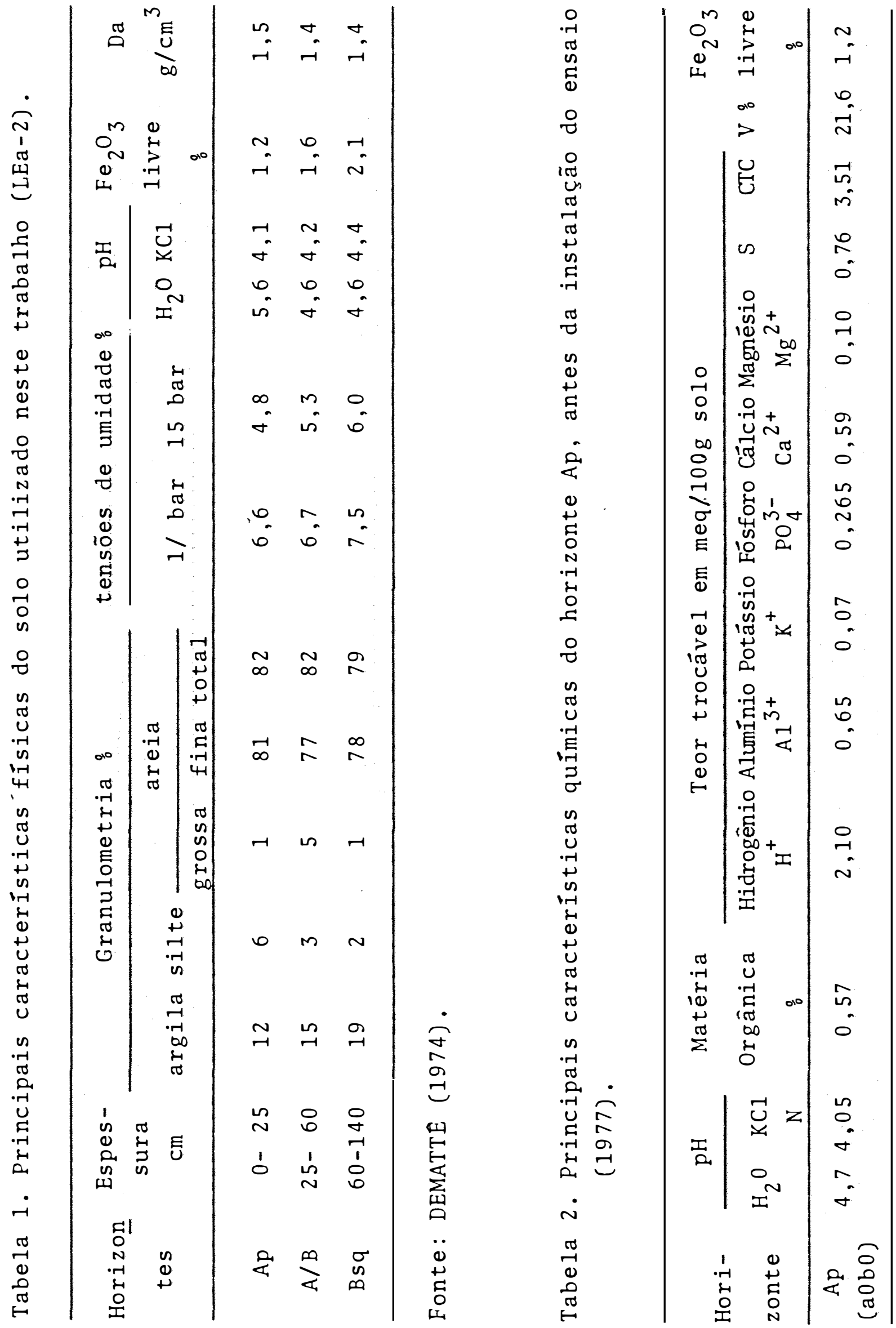


so, a quantidade de água disponível ao vegetal é baixa, mesmo considerando todo o perfil. Em períodos de estiagem tais solos secam rapidamente. (Tabela 1)

A precipitação pluviométrica no período do expe rimento atingiu as médias mensais de $113 \mathrm{~mm}, 104 \mathrm{~mm}, 95 \mathrm{~mm}$ e $135 \mathrm{~mm}$ para os anos de $1977,1978,1979$ e 1980, respectivamen te.

As determinações analíticas foram realizadas com amostras compostas do horizonte Ap de cada tratamento cole tadas no ano de 1979, conforme descrito em CATANI et alii (1955).

Anālises mineralógicas da fração argila de um solo LEa no município de Botucatu determinadas por GALHEGO (1973) revelaram a presença de $70,5 \%$ de caolinita e $6,0 \%$ de gibbsita.

3.3. Basalto Alterado

Tabela 3. Características químicas do basalto alterado (calculadas em T.F.S.A.).

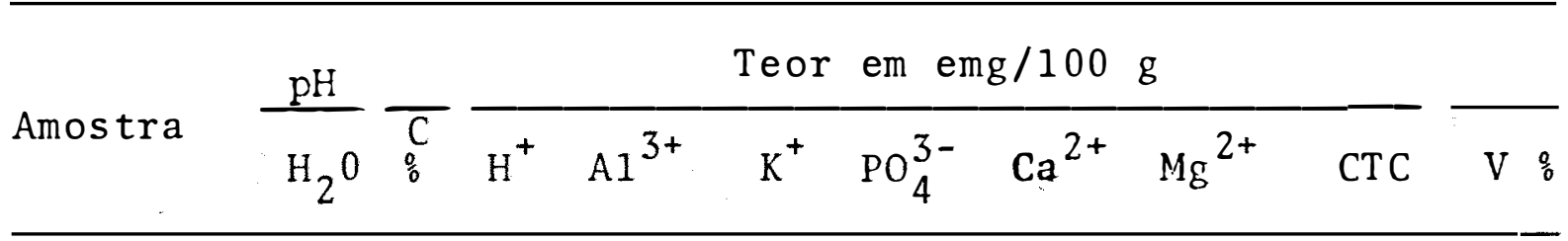

basal to

alterado $5,5 \operatorname{tr} 7,761,44 \quad 0,312 \quad 3,744 \quad 38,2018,0880,0486,6$ (M) 
Como melhorador de solo foi utilizado um produto de alteração de basalto, constituído predominantemente de argilas nontronitas de alta capacidade de troca cationica.

Esse material possui um teor de argila em torno de $70 \%$, e a sua capacidade de troca catiônica é de 80,04 emg/ $100 \mathrm{~g} \cdot(\mathrm{Tabela} 3)$

Sua gênese está ligada a processos hidrotermais de alteração devido a contato do derrame basāltico com sedi mentos eólicos porosos. A ocorrência desses materiais é bastan te generalizada em toda formação Serra Geral formando grandes jazidas. A Figura 1 representa o perfil geológico da ārea de coleta do material utilizado neste trabalho e, as Figuras 2 e 3 mostram a situação geogräfica do perfil bem como as delimitações prováveis das jazidas. Após a sua secagem procedeu-se a moa gem, passando 100\% em peneira de $1 \mathrm{~mm}$. Devido a sua genese hí drotermal os minerais de argila encontram-se em um grau de densamento bastante elevado, que mesmo após a moagem, a fra ção argila permanece em pequenos grânulos compactos, sem haver dispersão.

\subsection{Delineamento Experimental}

Foi utilizado um delineamento em blocos ao acaso, num esquema fatorial 4 x. 3 ( 4 níveis de basalto alterado e três níveis de adubação) envolvendo doze tratamentos com tres repetições. Os níveis de basalto alterado foram denominados de $a_{0}$ (sem adição), $a_{1}$ (dose equivalente a 0,33 CTC do 


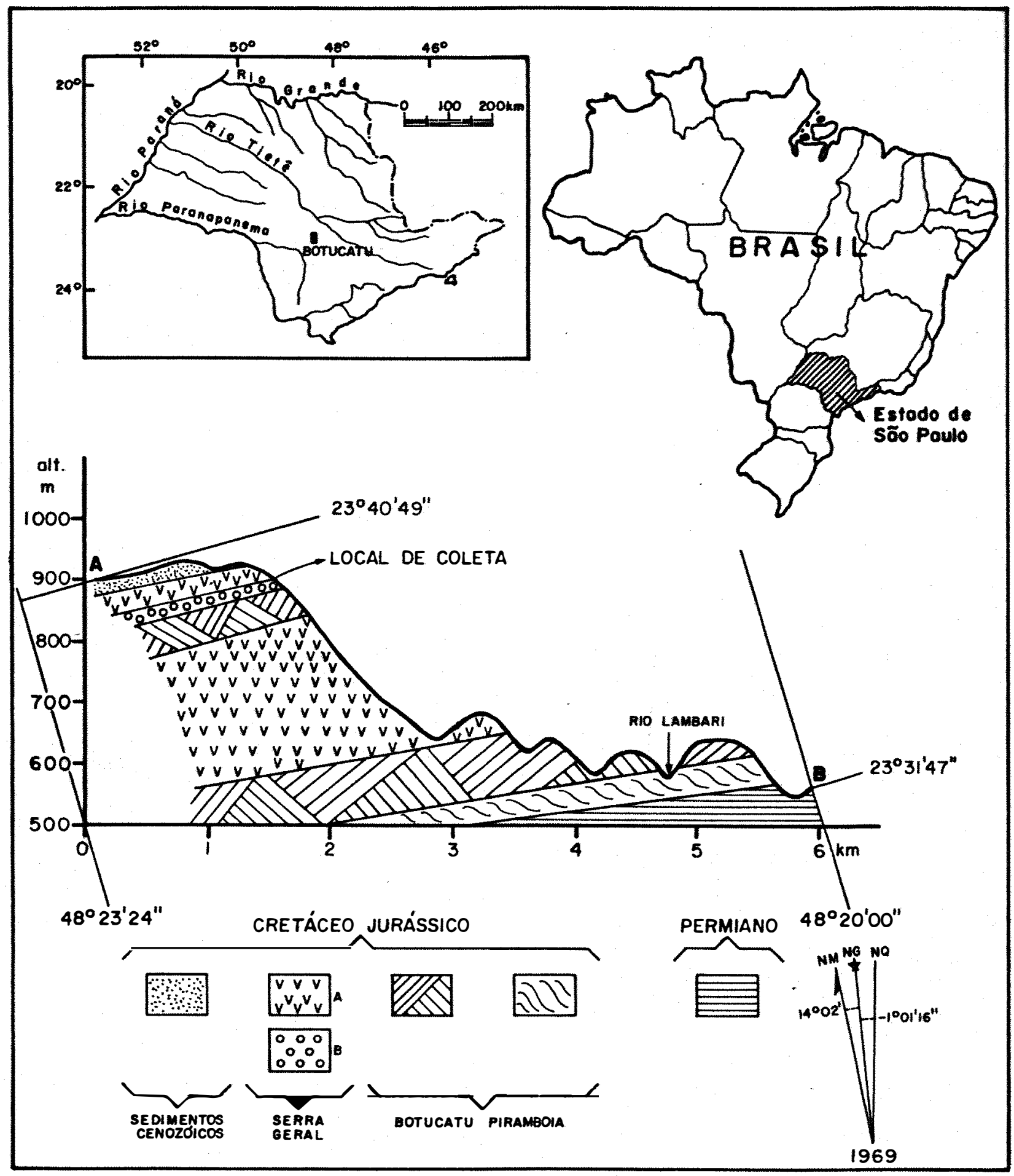

Figura 1. Perfil geológico da área de estudo de alteração em ro chas basálticas da Formação Serra Geral no município de Botucatu-SP. 


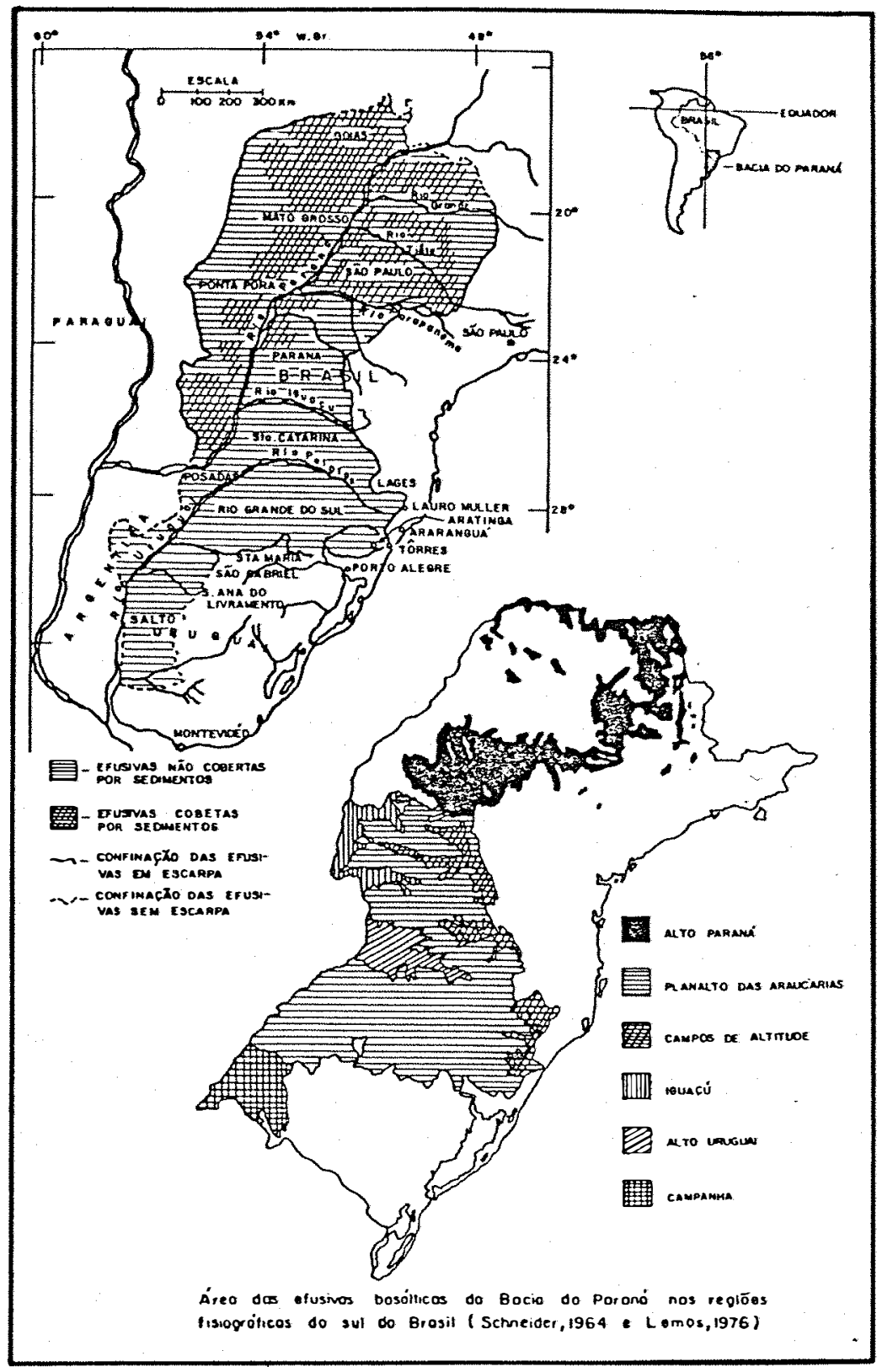

Figura 2. Distribuição geogrāfica das efusivas básicas no SuI do Brasil (SCHNEIDER, 1964 e LEMOS, 1976). 


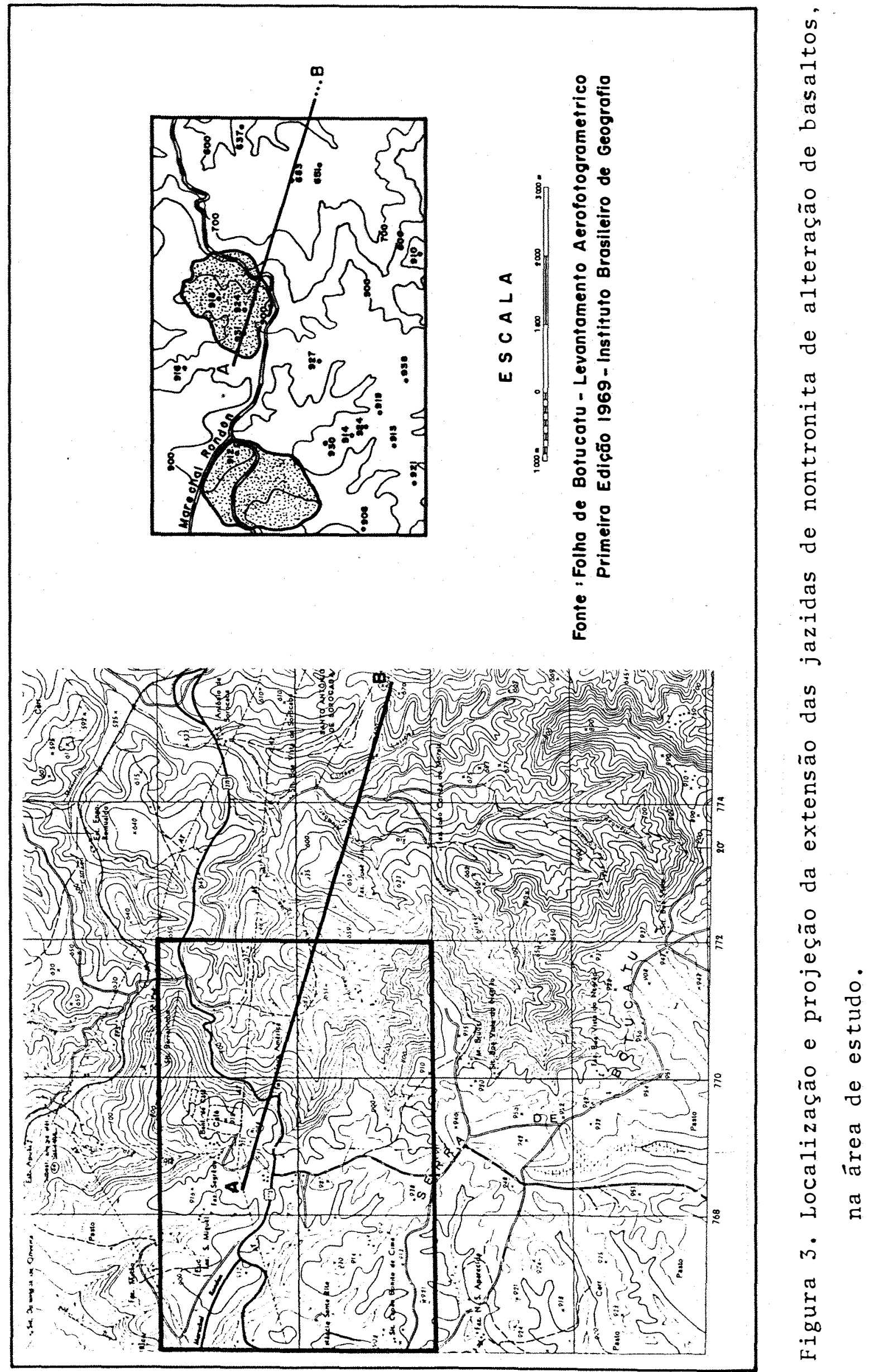


solo), $a_{2}$ (dose equivalente a 0,66 CTC do solo) e $a_{3}$ (dose e quivalente a 1,0 CTC do solo). Para a adubação usou-se a denominação $b_{1}\left(100 \%\right.$ da dose normal), $b_{2}\left(80 \%\right.$ da dose normal) e $b_{3}$ ( $60 \%$ da dose normal recomendada para cana-de-açúcar).

\subsection{Instalação e condução do ensaio}

0 ensaio foi instalado em uma ärea da Usina Bar ra Grande de Lençóis Paulista, constando de 36 parcelas de $75 \mathrm{~m}^{2}(7,5 \mathrm{~m} \times 10 \mathrm{~m})$. Considerando-se que a CTC inicial do so 10 era de $3,51 \mathrm{meq} / 100 \mathrm{~g}$ e a do basalto alterado (B) de 80,04 meq/100 g foram adicionados $0,120,240$ e $360 \mathrm{Kg}$ por parcela respectivamente às doses $a_{0}, a_{1}, a_{2} e a_{3}$; as quantidades de a dubo foram de $7,5,6,0$ e 4,5 $\mathrm{Kg} /$ parcela da fórmula 4-32-8, pa ra as doses $b_{1}, b_{2} e b_{3}$ respectivamente. Fez-se a incorporação mecânica do basalto alterado, e em seguida foram abertos cinco sulcos por parcela, adicionando-se as respectivas doses de adubo e executado o plantio da cana-de-açúcar. 0 experimen to foi instalado em abril de 1977 e as colheitas foram realiza das em setembro de 1978, 1979 e 1980. Após cada colheita foram feitas adubações de cobertura com $20 \mathrm{Kg} \mathrm{N} / \mathrm{ha}$ e $30 \mathrm{Kg} \mathrm{K} / \mathrm{O} / \mathrm{ha}$ a nualmente.

3.6. Determinações em Laboratório

3.6.1. Anālises químicas do solo e do basalto alterado Após dois anos de incubação do basalto alterado 
no solo foram feitas coletas de amostras compostas em cada re petição, fazendo-se a mistura das tres repetições obtendo-se no final uma única amostra por tratamento.

0 número de amostras a serem analisadas totalizaram 13 (12 tratamentos +1 do basalto alterado denominado de "M") •

\subsubsection{Determinação do $\mathrm{pH}$ e $\Delta \mathrm{pH}$}

Para verificar o comportamento do solo em rela ção aos principais ions de importância para as plantas e para estabelecer métodos comparativos de determinação das cargas permanentes do solo através dos valores de $\Delta \mathrm{pH}$, foram feitas determinações de $\mathrm{pH}$ em $\mathrm{H}_{2} \mathrm{O}$ e em soluções de concentração $1 \mathrm{~N}$ de $\mathrm{KCl}, \mathrm{MgCl}_{2}, \mathrm{CaCl}_{2}$ na relação 1:2,5 (solo:solução), tanto para o solo natural quanto para o solo lavado com $\mathrm{HCl} 0,01 \mathrm{~N}$. Esta técnica de diálise ácida constou de tres lavagens sucessi vas com $\mathrm{HCl} 0,01 \mathrm{~N}$ e em seguida, lavagem com água destilada, em centrifugador, até a ausência de ions $\mathrm{Cl}^{-}$(teste com nitrato de prata), na solução sobrenadante. Para as determinações de $\mathrm{pH}$ foi utilizado um potenciometro de leitura digital marca Micronal, modelo B 222 , com eletrodo combinado de vidro.

3.6.1.2. Determinações de matéria orgânica, Hi drogênio, Alumínio, Potássio, Fósforo, Cálcio, Magnésio e Cloreto.

Os métodos emṕregados nestas análises foram: 
a) M.O. pelo método de Walkey e Black modificado, descrito em MALAVOLTA e COURY (1954); b) Hidrogênio, alumínio, potássio, cálcio e magnésio trocáveis e o fósforo solúvel, conforme as recomendações de CATANI e JACINTO (1974), com leitura de K, Ca e $\mathrm{Mg}$ em um espectrofotômetro de absorção-atômica Perkim Elmer, modelo 503 ; c) $\mathrm{O} \mathrm{Cl}^{-}$foi determinado pelo método de Wolhard (MORITA e ASSUMPÇÃO, 1976).

3.6.1.3. Destruição da matéria orgânica pela $\mathrm{H}_{2} \mathrm{O}_{2}$, remoção dos óxidos de ferro li vre e preparação de lâminas para raios $\mathrm{X}$.

Para verificação da influência da matéria orgânica na CTC e suas propriedades eletroquímicas do solo e para posterior remoção dos óxidos de ferro livres, $50 \mathrm{~g}$ de cada tra tamento foram atacados com $\mathrm{H}_{2} \mathrm{O}_{2}$ de acordo com as instruções contidas em MENDES (1970). Após o término das reações, metade de cada amostra foi lavada tres vezes em água destilada, cen trifugada e armazenada na forma de suspensão. A outra metade sofreu tratamento para remoção dos óxidos de ferro livre de a cordo com a técnica recomendada por MENDES (1970).

$\mathrm{Na}$ parte deferrificada fez-se a separação da fração areia por peneiramento, limo e argila por sedimentação e argila grossa e fina por centrifugação, estas frações mais finas foram tornadas homoiônicas saturadas com $\mathrm{K}^{+}$e em se guida confeccionadas as lâminas para análises aos raios-X pelo método da pasta. 
3.6.1.4. Determinação da CTC

A capacidade de troca de cátions das amostras foi determinada pelo método do acetato de cálcio (GLORIA et alii, 1975), pelo método do azul de metileno (HANG e BRINDLEY, 1970; PAIVA NETTO e PACCOLA, 1974) e pela equaçāo $\sigma t=\sigma_{p}+\sigma_{v}$ onde $\sigma_{\mathrm{p}}=-\left[\mathrm{K}^{+}-\mathrm{Cl}^{-}\right]$e $\sigma_{\mathrm{v}}=1,67+10^{-6} \cdot \mathrm{n}^{1 / 2} \cdot(\mathrm{pHo}-\mathrm{pH}) \mathrm{de}$ acordo com as especificações de UEHARA e GUILMAN (1980a).

As determinações pelo método do acetato foram realizadas nas amostras naturais à $\mathrm{pH} 7,0$ e 5,0 enquanto naque las tratadas com $\mathrm{H}_{2} \mathrm{O}_{2}$ somente à $\mathrm{pH} 7,0$.

Os métodos do azul de metileno e das equações foram realizados apenas nas amostras naturais.

\subsubsection{Determinação do pHo}

Por definição pHo é o pH onde as cargas líqui das variáveis de superfície, resultantes do potencial determinado pelos ions $\mathrm{H}^{+}$e $\mathrm{OH}^{-}$são igual a zero.

Neste $\mathrm{pH}$, a adsorçāo de $\mathrm{H}^{+}$é igual a $\mathrm{OH}^{-}$. E o ponto de intersecção das curvas das titulações potenciométri cas a diferentes concentrações eletrolíticas. Estes dados fo ram obtidos de duas maneiras: a) pela titulaçāo contínua de $4 \mathrm{~g}$ de amostra natural em $10 \mathrm{ml}$ de soluções $(0,75 ; 0,075$ e $0,0075 \mathrm{~N}$ K $(1)$, com $\mathrm{NaOH} 0,005 \mathrm{~N}$ para o lado alcalino da curva a partir do $\mathrm{pH}$ do solo e com $\mathrm{HCl} 0,001 \mathrm{~N}$ do lado ácido. As duas cur vas foram unidas e consideradas apenas como titulaçāo equiva 
lentes à $\mathrm{NaOH}$, estando assim representadas graficamente.

As determinações foram realizadas em um pHmetro digital de duas casas decimais de precisão, marca Micronal, mo de1o B222 e com eletrodo combinado de vidro, sob agitação cons tante com agitador magnético. Os volumes de $\mathrm{NaOH}$ ou $\mathrm{HCl}$ gastos foram medidos em uma micro bureta de $5 \mathrm{ml}$, com precisão de $0,02 \mathrm{ml}$.

b) Pelo método da adição. De acordo com UEHARA e GUILMAN (1980b)o pHo é obtido da seguinte maneira: 1) lavar uma boa quantidade de amostra $( \pm 100 \mathrm{~g})$ com uma solução $1 \mathrm{M}$ de eletrolito KCl (ou NaC1) por duas a tres vezes; 2) em seguida lavar com $\mathrm{H}_{2} \mathrm{O}$ destilada até reduzir a concentração de eletroli to a um valor bem baixo $\left(0,002 \mathrm{M}\right.$ por ex., teste de $\mathrm{Cl}^{-} \mathrm{com} \mathrm{Ag}$ $\mathrm{NO}_{3}$ ) ; 3 ) tomar $4 \mathrm{~g}$ de amostra (equivalente a peso seco) em cada um de uma série de 10 copos becker de $50 \mathrm{ml}$; 4) adicionar \pm 15 ml de solução $0,002 \mathrm{M}$ de eletrólito e ajustar o pH com äcido ou base para obter uma amplitude de valores de $\mathrm{pH}$ que contenha com certeza o pHo (por ex.: 1,$5 ; 2,0 ; 2,5 ; 3,0 ; 3,5 ; 4,0 ; 4,5$; $5,0 ; 6,0$ e 7,0$) ; 5)$ completar o volume a $20 \mathrm{ml}$ com eletrólito $0,002 \mathrm{M}$ e deixar em equilíbrio por 3 a 4 dias em câmara úmida a gitando ocasionalmente; 6) registrar os valores de $\mathrm{pH}$ de equi líbrio ( $\mathrm{pH} 0,002 \mathrm{M}) ; 7$ ) adicionar $0,5 \mathrm{ml}$ de eletrólito 2M, agitar lentamente por 3 horas e anotar o $\mathrm{pH}(\mathrm{pH} 0,006) ; 8)$ adicio nar mais $1 \mathrm{ml}$ de eletrólito $2 \mathrm{M}$, agitar lentamente por mais 3 horas e anotar novamente $\circ \mathrm{pH}(\mathrm{pH} 0,010)$. Construir um gráfico plotando-se os valores de $\mathrm{pH}$ a várias concentraçōes eletrolít 
.68 .

cas contra os meq/100g gastos de ācido ou base para obter os valores de pH de equilíbrio em 0,002M (ou como descrito por UEHARA e GUILMAN, 1980b,plotar $\triangle \mathrm{pH}=\mathrm{pH}_{0,006 \mathrm{M}}-\mathrm{pH}_{0,002 \mathrm{M}}$ vs $\left.\mathrm{pH}_{0,002 \mathrm{M}}\right)$. O ponto de cruzamento entre as curvas ou onde $\Delta \mathrm{pH}=$ 0 é o pHo, o valor de $\mathrm{pH}$ que é independente da concentração e letrolítica.

3.6.1.6. Determinação das cargas permanentes $\left(\sigma_{\mathrm{p}}\right)$

a) Método da determinação de $\mathrm{K}^{+}$e $\mathrm{Cl}^{-}$a pHo (UE HARA e GUILMAN, 1980b) .

A determinação das cargas permanentes é obtida executando-se a seguinte marcha analitica: a) colocar $4 \mathrm{~g}$ (equi valente a peso seco) em tubos de centrífuga previamente tara dos), juntar $20 \mathrm{ml}$ de $\mathrm{KCl} 1 \mathrm{M}$ e agitar por uma hora; b) centrifugar e descartar o sobrenadante, lavar duas vezes com KCl $0,2 \mathrm{M}$ e em seguida tres a cinco vezes com $\mathrm{KCl} 0,01 \mathrm{M}$ ajustado ao pHo de cada amostra. Quando o pH da solução sobrenadante for igual ao pHo remover o sobrenadante e reter para análise de $\mathrm{K}^{+}$e $\mathrm{Cl}^{-}$; c) pesar os tubos para estimar o $\mathrm{KCl}$ da solução in terna; d) remover o $\mathrm{K}^{+}$e $\mathrm{Cl}^{-}$através de cinco lavagens com 20 ml cada vez, de $\mathrm{NH}_{4} \mathrm{NO}_{3} 0,5 \mathrm{M}$ e determinar $\mathrm{K}^{+}$e $\mathrm{Cl}^{-}$nos extratos acumulados; e) subtrair o KCl da solução interna para calcular o $\mathrm{K}^{+}$e $\mathrm{Cl}^{-}$adsorvido (ou repelido) como meq/100g; j) calcular as cargas permanentes pela expressão $\sigma_{p}=-\left[\mathrm{K}^{+}\right.$adsorvido - $\mathrm{Cl}^{-}$ adsorvido.] 
b) Pelo método da diferença entre $\mathrm{pH}_{\mathrm{H}_{2} \mathrm{O}}$ e $\mathrm{pH}^{\mathrm{CaCl}}{ }_{2}$

Este método é proposto aqui neste trabalho, e tem a seguinte marcha analítica: a) medir-se o $\mathrm{pH}$ em água 1 : 2,5 com $10 \mathrm{~g}$ de terra (equivalente ao peso seco em estufa); b) em seguida a mesma amostra é lavada tres vezes com $20 \mathrm{ml}$ de HC1 $0,01 \mathrm{~N} ; \mathrm{c})$ em centrífuga lavar com ägua destilada atē $\mathrm{C1}^{-}$ estar ausente na solução sobrenadante (teste $\mathrm{AgNO}_{3}$ ) neste pon to $\mathrm{pH}=\mathrm{pHo}$; d) transferir o solo centrifugado para um copo becker de $50 \mathrm{ml}$ juntamente com $25 \mathrm{ml}$ de $\mathrm{CaCl}_{2} 1 \mathrm{~N}$, agitar, de $\underline{i}$ xar em repouso por 3 horas e medir $\mathrm{opH}_{\mathrm{CaCl}}$; e) proceder o cálculo em meq/100g de $\mathrm{H}^{+}$pela diferença entre $\mathrm{pH}_{\mathrm{H}_{2} \mathrm{O}}$ e $\mathrm{pH} \mathrm{CaCl}_{2}$.

3.6.1.7. Determinação das cargas variáveis $\left(\sigma_{v}\right)$

As cargas variāveis, como o próprio nome diz, são cargas dependentes do $\mathrm{pH}$, isto é variam com o $\mathrm{pH}$ do meio. A sua determinação é obtida pela resolução da equação $\sigma_{V}=n^{1 / 2}$ $1,64 \times 10^{-6}$ (pHo - pH), (UEHARA e GUILLMAN, 1980b).

3.6.1.8. Determinação do ZPNC

0 ZPNC (ou PCLZ) é o ponto de carga líquida $\underline{i}$ gual a zero. E determinado usando-se o mesmo procedimento pa ra $\sigma_{p}(3.6 .1 .6$.$) , porém, com oito a dez pesagens iguais da$ 
mesma amostra, tendo seus valores de $\mathrm{pH}$ ajustados de modo a ob ter-se um intervalo que contenha o valor ZPNC esperado.

Depois de colocar $\mathrm{K}^{+}$e $\mathrm{Cl}^{-}$adsorvidos versus $\mathrm{pH}$ - $\mathrm{ZPNC}$ é $\mathrm{pH}$ correspondente ao ponto onde: $\mathrm{K}^{+}$adsorvido $=\mathrm{Cl}^{-}$ adsorvido.

\subsubsection{Determinação da superfície específica}

A determinação da superfície específica foi rea lizada por dois métodos:

a) Método da adsorção do vapor de etileno gli col $d=1,109$ e $n=1,4314$. Duas gramas de cada amostra saturada com cálcio, seca em estufa a $55^{\circ} \mathrm{C}$ até peso constante, é colocada em vapor de etileno glicol (P.a.) por 48 horas (até equilíbrio) dentro de uma câmara (dessecador de vidro) com um adsorbato de $\mathrm{CaCl}_{2}$ - etileno glicol. As amostras são retiradas da câmara e imediatamente pesadas. A superfície específica é calculada considerando-se que cada miligrama de etileno glicol ad sorvido cobre uma ārea de $3,22 \mathrm{~m}^{2}$ para argilas $1: 1 \mathrm{e} 6,44 \mathrm{~m}^{2}$ para argilas 2:1 e haloisita (GUYOT, 1969; BRADLEY, 1945).

b) Pelo método da adsorção negativa de $\mathrm{Cl}^{-}$da teoria de Gouy-Chapman (UEHARA e GUILLMAN, 1980b). Esta teoria afirma que quando a carga permanente é negativa, a superfície específica (S) é calculada usando-se um procedimento igual ao descrito em 3.6.1.6., porém com o pH da solução ajustado a tres ou quatro unidades acima do pHo e resolvendo-se a seguinte $\underline{\text { e }}$ 
quação:

$$
\gamma_{\mathrm{a}}^{-}=6,1 \times 10^{-9} \mathrm{~S}-\frac{3,774}{\gamma} \times 10^{-17} \mathrm{~S}^{2}
$$

onde:

$$
\begin{aligned}
\gamma_{\mathrm{a}}^{-}= & \mathrm{Cl}^{-} \text {repelido (adsorção negativa). } \\
\gamma= & \text { carga total da superfície }\left(\mathrm{K}^{+} \text {adsorvido }+\right. \\
& \mathrm{Cl}^{-} \text {repelido). } \\
\mathrm{S}= & \text { superficie específica em } \mathrm{m}^{2} / \mathrm{g} .
\end{aligned}
$$

c) Superfície específica de cargas variáveis-de terminada pela equação $\mathrm{S}_{v}=1,83 \gamma_{\mathrm{c}}^{-} \cdot 10^{2} \mathrm{~m}^{2} / \mathrm{g}$ onde $\gamma_{\mathrm{c}}^{-} \overline{\mathrm{e}}$ a ad sorção negativa de cátions a duas unidades de pH abaixo de pHo (UEHARA e GUILLMAN, 1980b).

d) Superfície específica de cargas permanentes determinada pela fórmula $S_{p}=s-S_{v} m^{2} / g$.

\subsubsection{Espectrografia de emissão.}

Para análise do basalto alterado por espectrografia de emissão foi utilizado um espectrógrafo marca JarrelAshell operando com arco de corrente contínua, e janela de 10u. A região fotografada foi de 2800 a $4300 \AA$ com chapas Kodak SAI. A amostra foi pulverizada, sendo utilizadas $10 \mathrm{mg}$ da rocha di luída em $90 \mathrm{mg}$ de $\mathrm{Li}_{2} \mathrm{CO}_{3}$ em eletrodo de Harvey. 
3.6.1.11. Determinação das relaçōes de atividades $(R A):$

$$
{ }^{a_{K}} \cdot\left({ }^{a} \mathrm{Ca}\right)^{-1 / 2} ;{ }^{a_{K}} \cdot\left({ }^{a} \mathrm{Mg}\right)^{-1 / 2} ;{ }^{a} \mathrm{~K} \cdot\left({ }^{a} \mathrm{Ca}+{ }^{a_{M g}}\right)^{-1 / 2} ;
$$

${ }^{\mathrm{a}} \mathrm{Ca} /{ }^{\mathrm{a}} \mathrm{Mg}$.

As determinações analíticas, empregadas na ava liação das relações de atividades, foram executadas de acordo com a técnica de Van RAIJ citada por SOARES (1975), que con siste na seguinte marcha analítica: cinco gramas de terra seca em estufa a $55^{\circ} \mathrm{C}$ de cada amostra, são postas em equilíbrio com $50 \mathrm{ml}$ de solução $10^{-2} \mathrm{M}$ de $\mathrm{CaCl}_{2}$, por agitação durante quinze minutos em agitador horizontal. Em seguida procede-se a filtra ção através de papel de filtro Whatman n 40. As determinações de cálcio, potássio e magnésio, neste extrato, foram feitas em um espectrofotômetro de absorção atômica Perkin Elmer, modelo 503. Com os dados obtidos calculou-se a intensidade ou relação de atividades entre os ions potássio,cálcio e magnésio, segunfo DAVIDESCU et alii (1966).

Os coeficientes de atividade foram calculados de acordo com a segunda aproximação da equação de Debye e Hu ckel, juntamente com as atividades dos cátions, segundo DAV $\underline{I}$ DESCU e BORLAN (1968) através das equações que se seguem:

a) Os coeficientes de atividades f, (I) para o ion cálcio; (II) para o ion magnésio e, (III) para o ion potás sio. 


$$
\begin{aligned}
& \log f_{C a}=-\frac{4,0 \cdot 0,508 \cdot(\mu)^{1 / 2}}{1+1,312 \cdot(\mu)^{1 / 2}} \\
& \log f_{M g}=-\frac{4,0 \cdot 0,508 \cdot(\mu)^{1 / 2}}{1+2,628 \cdot(\mu)^{1 / 2}} \\
& \log f_{K}=-\frac{0,508 \cdot(\mu)^{1 / 2}}{1+1,5(\mu)^{1 / 2}}
\end{aligned}
$$

b) A força iônica $\mu$ é calculada pela equação:

$$
\mu=\frac{1}{2} \cdot \Sigma \mathrm{mi} \cdot \mathrm{Zi}^{2}
$$

onde mi é a concentração molar do ion e $z i$ é a valência desse ion.

c) A atividade de um ion é dada por:

$$
a=f \cdot m
$$

onde $f$ é o coeficiente de atividade e m a concentração molar.

$$
\text { d) As relações de atividades para o potássio }
$$
$\left(\mathrm{RA}^{\mathrm{K}}\right)$ são dadas pelas fórmulas:

$$
\begin{aligned}
& \mathrm{RA}_{\mathrm{Ca}}^{\mathrm{K}}={ }^{\mathrm{a}} \mathrm{K} \cdot\left({ }^{\mathrm{a}} \mathrm{Ca}\right)^{-1 / 2} \\
& \mathrm{RA}_{\mathrm{Mg}}^{\mathrm{K}}={ }^{a_{K}} \cdot\left({ }^{\mathrm{a}} \mathrm{Mg}\right)^{-1 / 2} \\
& \mathrm{RA}_{\mathrm{Ca}+\mathrm{Mg}}^{\mathrm{K}}={ }^{a} \mathrm{~K} \cdot\left({ }^{\mathrm{a}} \mathrm{Ca}+{ }^{a} \mathrm{Mg}\right)^{-1 / 2}
\end{aligned}
$$


onde ${ }^{a_{K}},{ }^{a} \mathrm{Ca},{ }^{a} \mathrm{Mg}$ são as atividades dos ions potássio, cálcio, magnésio, respectivamente.

e) As relações de atividade para o ion Cálcio $\left(R A_{M g}^{\mathrm{Ca}}\right)$ é dada pela fórmula:

$$
\mathrm{RA}_{\mathrm{Mg}}^{\mathrm{Ca}}={ }^{\mathrm{a}} \mathrm{Ca} \cdot\left({ }^{\mathrm{a}} \mathrm{Mg}\right)^{-1}
$$

3.6.1.12. Coeficiente de seletividade $\left(K_{c}\right)$.

De acordo com MCBRIDE (1979) o coeficiente de seletividade é dado pelas expressões:

$$
\begin{aligned}
& \mathrm{K}_{\mathrm{c}}=\frac{\left[\overline{\mathrm{K}^{+}}\right] \cdot\left(\mathrm{Na}^{+}\right)}{\left[\overline{\mathrm{Na}^{+}}\right] \cdot\left(\mathrm{K}^{+}\right)} ; \\
& \mathrm{K}_{\mathrm{c}}=\frac{\left[\overline{\mathrm{K}^{+}}\right] \cdot\left(\sqrt{\mathrm{Mg}^{+2}}+\sqrt{\mathrm{Ca}^{+2}}\right)}{\left[\overline{\mathrm{Mg}^{+2}}+\overline{\mathrm{Ca}^{+2}}\right] \cdot\left(\mathrm{K}^{+}\right)}
\end{aligned}
$$

onde :

$\left[\overline{\mathrm{Ca}}^{2+}\right],\left[\overline{\mathrm{Mg}}^{2+}\right],\left[\overline{\mathrm{K}}^{+}\right]$e $\left[\overline{\mathrm{Na}}^{+}\right]$são frações equivalentes dos sitios de troca da argila ocupados por $\mathrm{K}^{+}$e $\mathrm{Na}^{+}$respectivamente. São obtidos da divisão:

$$
\frac{\left(\mathrm{K}^{+}, \mathrm{Na}^{+}, \mathrm{Mg}^{2+}, \mathrm{Ca}^{2+}\right)^{\mathrm{meq} / 100 \mathrm{~g} \text { solo }}}{\text { CTC calculada }}
$$

e

$$
\left(\mathrm{Na}^{+}\right),\left(\mathrm{K}^{+}\right),\left(\mathrm{Mg}^{2+}\right) \text { e }\left(\mathrm{Ca}^{2+}\right)
$$

as atividades obtidas no ítem 3.6 .1 .11 . 
4. RESULTADOS. E DISCUSSÃO

4.1. Geologia e Solos

4.1.1. Geologia

No local de coleta do basalto alterado, utiliza do neste trabalho, são perfeitamente distinguíveis as formações geológicas de eruptivas básicas constituídas de várias corridas de lavas separadas pela ocorrência de basalto vesicular no contato com o arenito eólico, tal como descreve a COMI $\underline{S}$ SÃO INTERESTADUAL DA BACIA PARANA-URUGUAI (1964).

Essa região de contato, se por um lado promoveu metamorfismo no arenito, em contrapartida o basalto sofreu pro fundas alterações mineralógicas de caráter hidrotermal, como sustentam EINSELE et alii (1980) para as intrusões de sills de basaltos em sedimentos porosos, assim como BOCKHEIM \& BALLARD (1975) sugerem o mesmo fenômeno com surgimento de minerais se cundários característicos. 
A Figura 1 representa o perfil geológico da $\underline{a}$ rea em estudo. Nesse local as camadas alteradas variam de al guns centímetros a vários metros de espessura apresentando sem pre argilas verdes em placas e mais frequentemente em glóbulos maciços preenchendo total ou parcialmente as cavidades. Obser vações mais acuradas deste material alterado revelaram que não apenas as cavidades estão constituídas de argilas nontroní ticas como afirmam RAW e MATLEY (1943); ALLEN e SCHIED (1946); FRANCO (1952) e SOUZA SANTOS e RUIZ (1963), mas também toda massa rochosa sofreu alteração com recristalização de nontroni ta como mostram os resultados da análise granulométrica com $70 \%$ de argila e os valores da capacidade de troca cationica de 80,04 meq/100g de material (Tabela 3 ).

A ocorrência das zeolitas, analcima e estilbita é bastante generalizada sendo mesmo visíveis macroscopicamen te, formando cristais bem desenvolvidos, concordando com BOCK HEIM e BALLARD (1975) e HAWKINS e ROY (1963) que atribuem sua origem a processos hidrotermais.

As anālises da fração argila do basalto altera do, através da difração de raios-X (Figura 4) mostram claramen te a predominância absoluta de minerais $2: 1$ com picos a $16 \AA$ para a amostra natural que expande para $18 \AA$ com a glicolação. A saturação com potássio reduz o espaçamento basal para $12,2 \AA$ enquanto que o aquecimento a $350^{\circ} \mathrm{C}$ e $500^{\circ} \mathrm{C}$ reduzem-no para $10 \AA$ respectivamente.

A caolinita aparece muito debilmente com pico a 


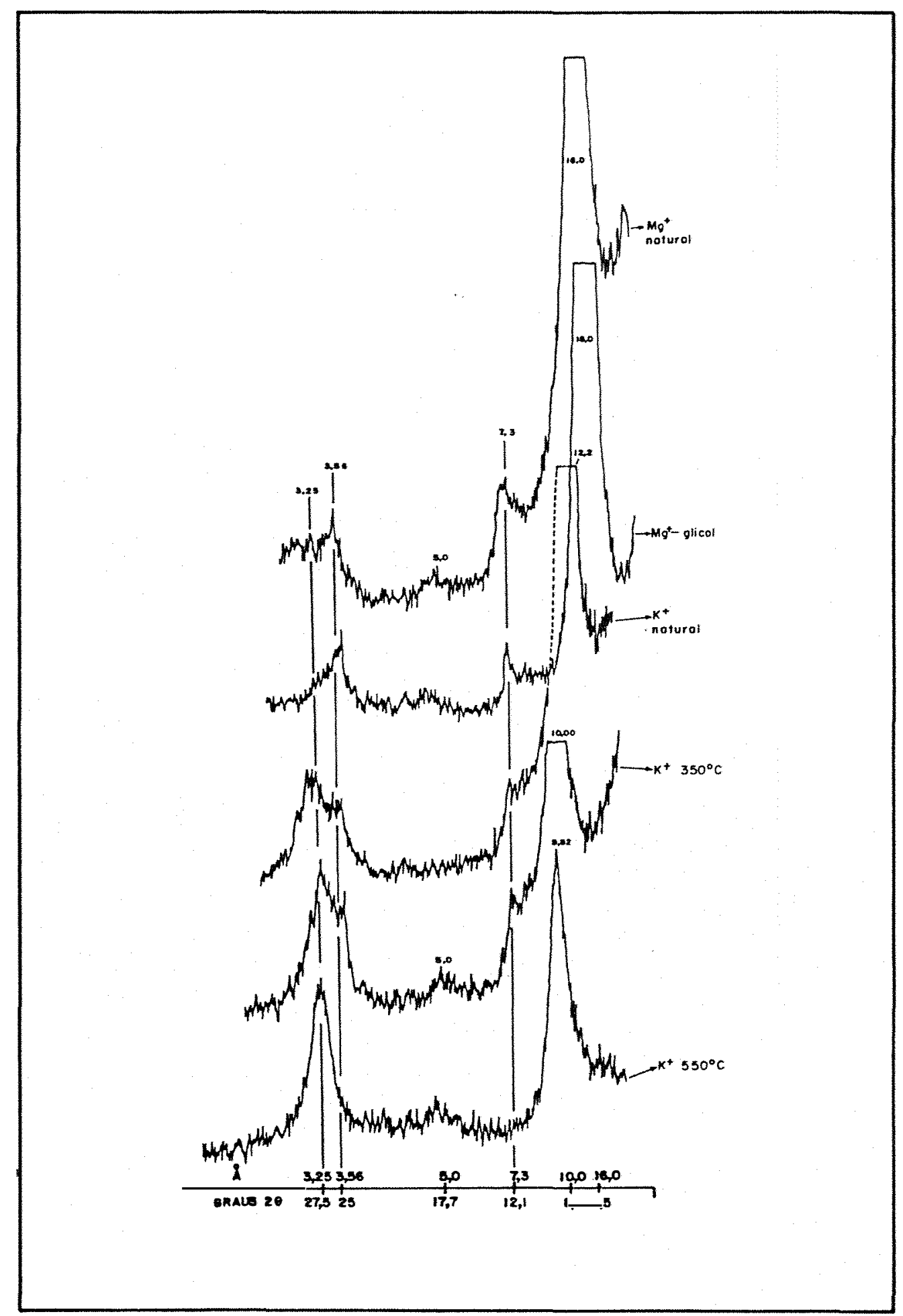

Figura 4. Difratogramas de raios-X da fração argila do basalto alterado. 
$7,3 \AA$ e $3,56 \AA$ porëm, mostrando um baixo grau de cristalinida de com picos assimétricos e na forma de banda indicando a exis tência provāvel, também de "fire-clays"e/ou metahaloisita confirmando os resultados obtidos por BOCKHEIM e BALLARD e ESPINDOLA (1979), GALHEGO et alii (1979) para a alteração de rochas bāsicas.

Os picos característicos da nontronita a $16 \AA$ para amostra natural, 12,2 para a $\mathrm{K}^{+}$saturada e $18 \AA$ para a amostra $\mathrm{Mg}^{2+}$ glicolada são muito intensos e bem definidos, $\underline{a}$ presentando uma amplitude da base que encobre a região de $10 \AA$ ou mesmo da mica também a $10 \AA$ que esboça a mostrar-se pela presença de pequeno pico de $2^{\text {a }}$ ordem a $5,0 \AA$.

As anālises por espectrografia de emissão no ba salto alterado, revelam a presença dos seguintes elementos me nores $(1$ a $0,1 \%)$ : o manganês, o titanio, o zinco e o cobre; e como elementos traços $(<0,1 \%)$ o vanádio, o zirconio, o cromo, o osmio e o rhodio.

A presença desses elementos traços na rocha al terada são bons indicadores do processo hidrotermal de altera f̧ão sofrido pelo basalto, concordando com HUMPHRIS e THOMPSON, (1978) .

A ocorrência da nontronita juntamente com os elementos menores zinco, manganês e cobre também foi constatada por HEIN et alii (1979) que estudando a presença de montmorilonita enriquecida de ferro em nódulos manganíferos verifí caram que essas argilas continham relativamente abundantes 
quantidades desises elementos.

Consequentemente os pequenos teores de óxidos de ferro livre neste material não proporciona a retenção de elementos como cobalto, scandio, thório e urânio como relata KOONS et alii (1980).

Cabe salientar aqui que a ocorrência de cristobalita constatada por ESPINDOLA (1979) em solos de pedogênese em āreas basálticas do Estado de São Paulo, vem também corrobo rar na caracterização do processo metassomático hidrotermal pa ra a alteração do basalto como afirma BOCKHEIM e BALLARD(1975), principalmente nos contatos com os sedimentos eólicos porosos da formação Serra Geral.

Todas essas evidências sobre a ação de metasso matismo hidrotermal sobre as rochas basálticas, vem assim, re forçar a hipótese de MONIZ e JACKSON (1967) como uma das possí veis explicações para a diferenciação dos solos Latossol Roxo e Terra Roxa Estruturada e,ainda, associado a tal mecanismo po demos, sem dúvida,acrescentar à hipótese dos referidos autores, a presença da nontronita como mineral intermediário nos processos de laterização com produção de caolinita, gibbsita e óxidos de ferro, alumínio e manganês. Entretanto fazemos uma ressalva quanto à conservação da estrutura original da rocha, uma vez que o remanejamento dos produtos de alteração é muito frequentemente,marcado pela presença de linhas de pedras.

A extensão geológica atingida por este processo de alteração é de grande monta atingindo toda a formação Serra Geral onde se encontram as escarpas com o arenito eólico cita 
das por ALMEIDA (1964). Outros pontos observados no decorrer das excursões de campo efetuadas durante a realização desse tra balho dão-nos indicações da ampla extensão geológica atingida por este fenômeno.

A ocorrência dessas jazidas (Figura 3) de non tronitas parece vir preencher uma lacuna na exploração mineral no planalto ocidental paulista pois como afirma ZANDONADI (1972) até aquela data não se conheciam reservas economicamen te exploráveis de nontronitas de rochas básicas para utiliza ção industrial, pois as citações de LEINZ (1949), PAIVA NETTO (1949), FRANCO (1952) e outros, apenas faziam referência a pre sença desse mineral nos produtos de alteração do basalto.

\subsubsection{Solos}

Antes da instalação do experimento de campo fo ram feitas análises químicas de rotina do solo (Tabela 2), que revelaram uma pobreza química muito pronunciada sendo evidenciada por um valor de 0,76 emg/100g para a soma de bases, e com um Vo de 21,6. Entretanto, o teor de fósforo solüvel apre senta-se em nível médio devido às adubações fosfatadas aplica das nos sucessivos plantios da cana-de-açúcar. A Tabela 3 apre senta valores de $0,57 \%$ para matéria orgância e pH igual a 4,7 mostrando também a má qualidade química deste solo. Embora, o teor de matéria orgânica seja considerado baixo pelos níveis estabelecidos a sua participação relativa na capacidade de tro ca catiônica é grande, atingindo valores até $50 \%$ (Tabela 5) de 
.81 .

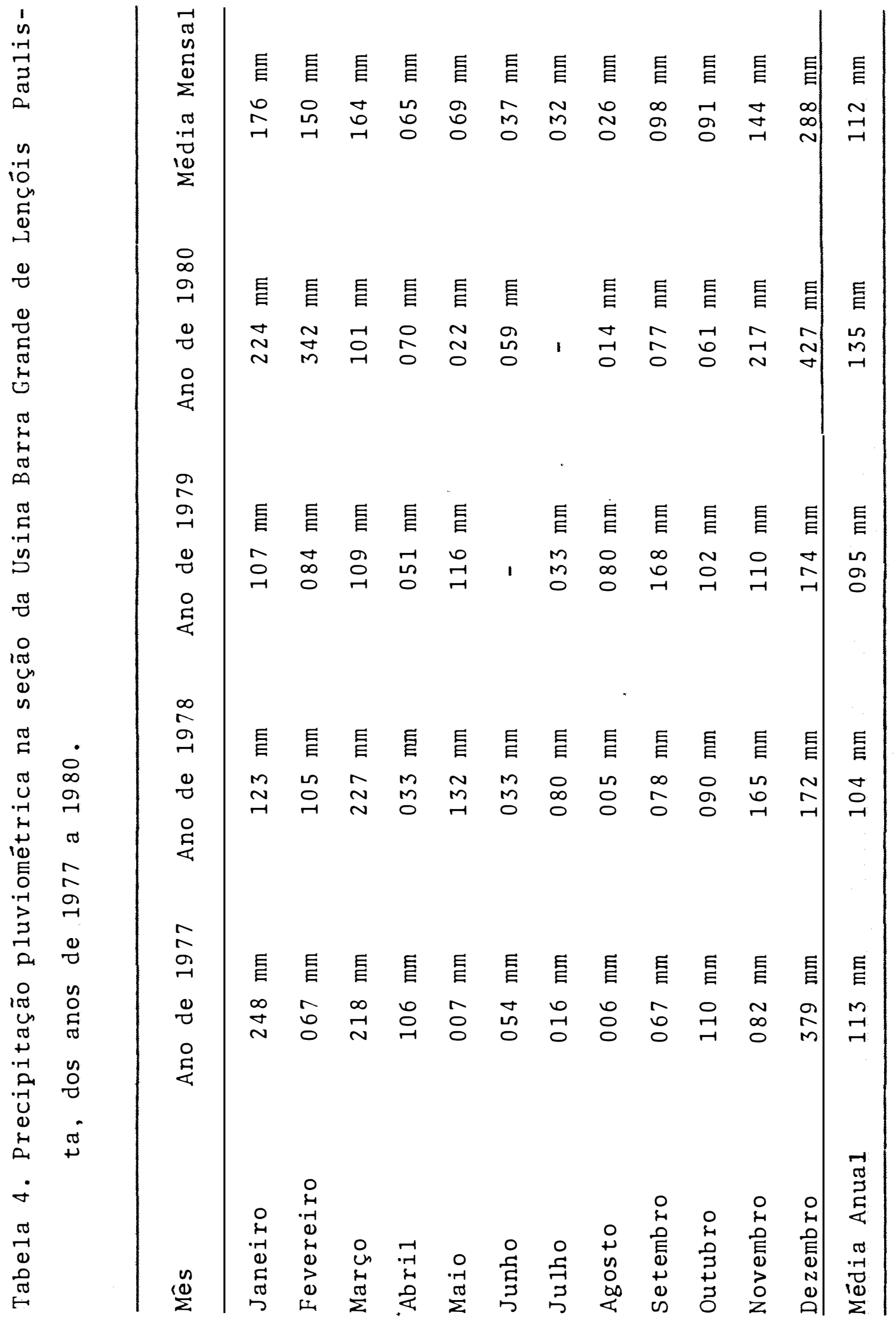


Tabela 5. Valores da capacidade de troca cationica e teores : de matéria orgânica do basalto alterado, e do horizonte Ap $(0-25 \mathrm{~cm})$ do solo e dos tratamentos em condições de campo, coletados nos anos de 1978 e 1979.

\begin{tabular}{|c|c|c|c|c|c|c|c|c|c|c|c|c|c|}
\hline \multirow{3}{*}{$\begin{array}{c}\text { Tratamentos } \\
\text {. }\end{array}$} & \multicolumn{5}{|c|}{ CTC meq/100g (79) } & \multicolumn{3}{|c|}{ M.O.: } & \multirow{2}{*}{\multicolumn{2}{|c|}{$\operatorname{CTC} \stackrel{(8)}{\text { meq }} / 100 \mathrm{~g}$}} & \multirow{2}{*}{\multicolumn{2}{|c|}{ (9) CTC meq/100g }} & \multirow{3}{*}{$\frac{\mathrm{pH}\left(\mathrm{H}_{2} \mathrm{O}\right)}{79}$} \\
\hline & \multicolumn{3}{|c|}{ (1) $\mathrm{A}_{1}$} & \multirow{2}{*}{$\frac{{ }^{(2)} B_{1}}{\mathrm{pH}_{7,0}}$} & \multirow[t]{2}{*}{${ }^{(3)} \mathrm{C}$} & \multicolumn{2}{|c|}{$\mathrm{A}_{2}$} & \multirow{2}{*}{$\frac{\mathrm{B}_{2}}{79}$} & & & & & \\
\hline & $\mathrm{a} \cdot \mathrm{m} \cdot \mathrm{I}$ & $\mathrm{pH} 7,0 \mathrm{P}$ & $\mathrm{pH} 5,0$ & & & (4) 78 & 79 & & 78 & 79 & $(10)_{\mathrm{MO}}$ & $\begin{array}{c}(11) \\
:=\end{array}$ & \\
\hline$a_{0} b_{1}$ & 3,09 & 3,92 & 3,18 & 2,17 & 1,75 & 0,91 & 0,83 & 0,03 & 3,35 & 3,40 & 210,84 & 10,85 & 5,03 \\
\hline$a_{0} b_{2}$ & 3,12 & 4,10 & 3,23 & 2,09 & 2,01 & 0,93 & 1,09 & 0,02 & 3,37 & 3,48 & 184,40 & 10,45 & 5,14 \\
\hline$a_{0} b_{3}$ & 3,19 & 4,12 & 3,23 & 2,43 & 1,69 & 0,99 & 0,83 & 0,03 & 3,68 & 3,34 & 203,61 & 12,15 & 4,97 \\
\hline$a_{1} b_{1}$ & 3,51 & 4,52 & 3,25 & 2,57 & 1,95 & 0,98 & 0,88 & 0,03 & 3,34 & 4,06 & 221,59 & 12,85 & 4,98 \\
\hline$a_{1} b_{2}$ & 3,45 & 4,61 & 3,22 & 2,69 & 1,92 & 0,88 & 0,93 & 0,03 & 3,56 & 4,01 & 206,45 & 13,45 & 5,05 \\
\hline$a_{1} b_{3}$ & 3,48 & 4,35 & 3,24 & 2,52 & 1,83 & 0,82 & 1.03 & 0,12 & 3,19 & 4,29 & 201,10 & 12,60 & 5,05 \\
\hline$a_{2} b_{1}$ & 3,64 & 5,61 & 4,13 & 2,91 & 1,70 & 0,87 & 0,93 & 0,07 & 4,04 & 5,07 & 197,67 & 14,55 & 5,17 \\
\hline$a_{2} b_{2}$ & 3,64 & 5,22 & 4.23 & 2,96 & 2,16 & 1,19 & 0,83 & 0,02 & 4,44 & 5,01 & 260,24 & 14,80 & 4,98 \\
\hline$a_{2} b_{3}$ & 3,64 & 5,36 & 4,12 & 2,78 & 2,18 & 1,09 & 1,09 & 0,02 & 4,35 & 4,90 & 200,00 & 13,90 & 5,02 \\
\hline$a_{3} b_{1}$ & 3,89 & 7,69 & 5,01 & 4,57 & 2,12 & 0,88 & 1,34 & 0,12 & 5,23 & 6,10 & 173,77 & 22,85 & 5,05 \\
\hline$a_{3} b_{2}$ & 3,87 & 7,18 & 4,95 & 4,17 & 2,01 & 1,24 & 1,24 & 0,09 & 4,99 & 5,69 & 174,78 & 20,85 & 5,12 \\
\hline$a_{3} b_{3}$ & 3,87 & 6,31 & 4,76 & 3,39 & 1,92 & 1,24 & 0,83 & 0,01 & 4,42 & 5,39 & 234,14 & 16,95 & 5,06 \\
\hline$(5)_{M}$ & 32,35 & 80,04 & $68,69^{(6)}$ & 6) n.d. & - & $\operatorname{tr}$ & n.d. & n.d. & 66,15 & n.d. & $n \cdot t$. & 114,34 & 5,77 \\
\hline (7) $a_{0} b_{0}$ & n.d. & n.d. & n.d. & n.d.. & - & 0,57 & n.d. & n.d. & 3,51 & n.d. & n.d. & n.d. & 4,70 \\
\hline
\end{tabular}

(1) A - solo natural; a.m. - método do azul de metileno; pH $(7,0$ e 5,0$)$ métodos do acetato de cálcio. (2) B - solo tratado com $\mathrm{H}_{2} \mathrm{O}_{2} \cdot$ (3) $\mathrm{C}$ - diferença $\left[\mathrm{A}_{1}(\mathrm{pH}+7,0)-\mathrm{B}\right\}$ (4) 78 e 79 - anos das coletas de a mostras. (5) M - material usado no solo (basalto alterado). (6) n.d. - nāo determinado. (7) a bo - solo natural. (8) CTC - calculada pela sona das bases mais $\mathrm{H}^{+}$e $\mathrm{Al}^{3+}$. (9) CTC determinada pelo método do ace tato de cálcio $\mathrm{N} \mathrm{pH} \mathrm{7,0.} \mathrm{(10)} \mathrm{M.0.} \mathrm{fraçāo} \mathrm{matéria} \mathrm{orgànica} \mathrm{do} \mathrm{solo.} \mathrm{(11)} \mathrm{Mineral} \mathrm{-} \mathrm{fraçāo} \mathrm{argilamineral.}$ 
vido ao pequeno teor de argila do solo, e também pela baixa atividade das espécies minerais presentes nesta fração tal co mo afirma DEMATTE (1974). Esta condição vem explicar os resultados obtidos para o bom nível de fósforo solúvel encontrado neste solo, tendo-se em consideração as afirmações de GAUR (1969) de que a redução da fixação dosfosfato no solo é devido à formação de complexos estáveis entre os compostos húmicos e os colóides da fração mineral. Ou ainda, como afirmam OBIHARA e RUSSEL (1972), os sítios de adsorção por fosfatos dos óxidos de ferro podem estar bloqueados por grupamentos silanois que tambēm se fixam fortemente a esses colóides. Esta ültima hipótese se torna provável, uma vez que estes solos embora situemse entre os mais intemperizados apresentam baixos teores de gibbsita, evidenciando uma fraca dessilicificação da caolinita As anālises mineralógicas da fração argila fei tas por difratometria de raios-X revelam a predominância absot luta de caolinita bem cristalizada com picos a $7,2 \AA$ e $3,56 \AA$, seguida de pequena quantidade de gibbsita com pico a 4,85 凡.Na Figura 5 são apresentados os gráficos dessas anālises que mos tram uma grande semelhança mineralógica tanto para a fração a gila fina como para a argila total do solo natural, concordan do com os dados de GALHEGO e ESPINDOLA (1975).

Nos difratogramas de raios-X referentes aos tra tamentos com aplicação de basalto alterado (Figuras 5a e 5d) é constatada a ocorrência de minerais com espaçamentos de $10 \AA$, que embora débil, caracteriza a presença da montmorilonita de alta carga saturada com potássio, que sofreu redução do espaça 


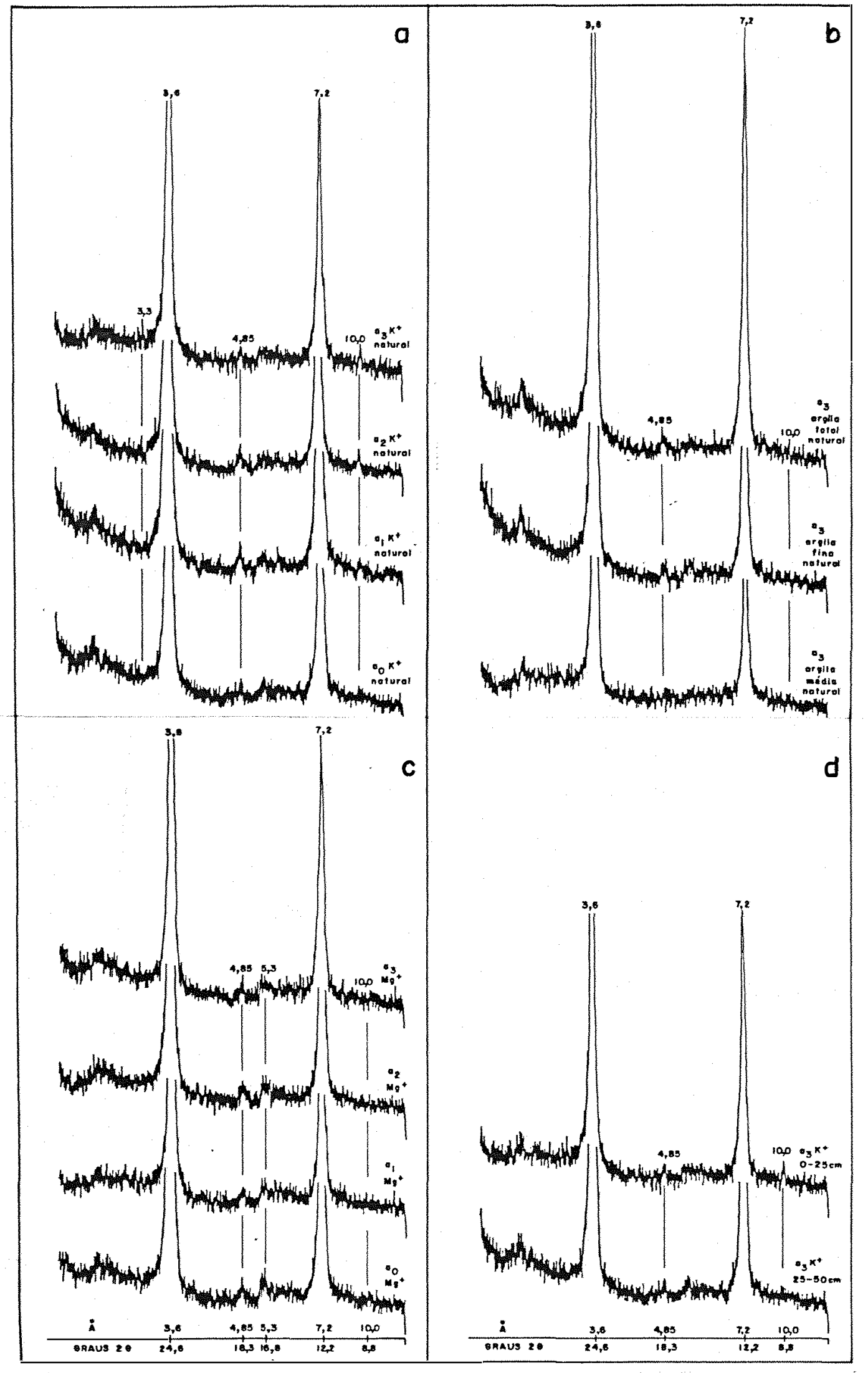

Figura 5. Difratogramas de raios-X da fração argila. a. das a mostras saturadas com $\mathrm{K}^{+}, \mathrm{b}$. da argila total, mëdia e fina, c. as amostras saturadas com $\mathrm{Mg}$, d. para as camadas $0-25 \mathrm{~cm}$ e $25-50 \mathrm{~cm}$ da amostra $\mathrm{a}_{3}$. 
mento basal, tal como pressupõe MIELNCZUK (1978). A pequena proporção de montmorilonita na fração argila indica o pequeno grau de dispersão em que se encontra o basalto alterado, tal como nos referimos anteriormente e assim justifica o baixo va lor da CTC encontrado pelo método do azul de metileno descrito por HANG e BRINDLEY (1970) e PAIVA NETTO e PACCOLA (1974). Os resultados mais baixos avaliados por esse método podem ser ex plicados, ou pela ocorrência de um comportamento da nontronita semelhante à vermiculita, por redução do espaçamento basal, cị tado por ALEXIADES e JACKSON (1965), CHU (1977) e CHU e JONSON (1979), ou ainda pelo fenômeno da histerese de troca iônica descrito por Van BLADEL e LAUDELOUT (1967).

\subsection{Interação entre Solo e Basalto Alterado.}

A aplicação do basalto alterado visando promo ver um aumento na capacidade de troca catiônica do solo, traz, como consequência inerente aos teores de elementos nutrientes nele contidos, um aumento da fertilidade do:solo. Tal como o obtido por PIERI (1977) com a aplicação de ghoetita e fosfato monocālcico, a elevação da CTC do solo pela adição de basalto alterado à nontronitas, assume aspectos de importância, levando-se em conta a longa durabilidade do efeito produzido, quando se compara com a aplicação de matéria orgânica de carāter mais efêmero.

A granulometria do material empregado neste tra balho, bem como a pequena dispersão da fração argila, jä comen 
tados anteriormente, assume dois aspectos distintos e de efe tos contrários. Por um lado, o pequeno grau de dispersão das argilas retardam as reações de troca iônica como relatam Van BLADEL e LAUDELOUT (1967), diminuindo a velocidade de fornecí mento de nutrientes à solução do solo e consequentemente às raízes das plantas. Por outro lado, essa mesma situação impede que ocorra a migração das argilas de alta atividade para cama das mais profundas do perfil (Figura 5d), bem como retarda as perdas de nutrientes por lixiviação.

Outro aspecto positivo da aplicação de nontroni tas ao solo, refere-se ao fornecimento de sílica soúvel ao so10 por degradação da rede cristalina desses minerais que são mais intemperizaveis, tal como afirmam NOVAK e ČIČEL (1978) e, considerando ainda, que os latossolos são normalmente pobres em silica solúvel apreciando-se os relatos de ROSS et alii (1974) e GASCHO e ANDREIS (1974) que propuzeram a aplicação de silicato de cálcio para a correção de tal deficiência.

A técnica utilizada por SINGH et alii (1979) na India, aplicando camadas de bentonita formando uma barreira sub superficial para evitar a perda de água por percolação, prova velmente, não seria adequada às nossas condições climáticas, onde certamente provocaria erosão laminar devido ao excesso de precipitação em determinados períodos do ano como mostra a Ta bela 4 .

As argilas nontroniticas que predominaram no pro cesso de alteração do basalto empregado neste trabalho e que 
ocorre em grandes extensões geológicas possuem características mineralógicas muito diversas daquelas referentes aos colóides existentes no solo, o que, segundo COLEMAN e PEECH (1954) apre sentam propriedades de troca iônica e seletividade também dife rentes.

Essas diferenças refletem-se diretamente nos ín dices de relações de atividade e consequentemente na absorção de nutrientes pelasplantas, bem como nas perdas por lixiviação, principalmente quando ocorrem mudanças no pH, uma vez que a maior proporção das cargas das nontronitas são permanentes.

\subsection{Anālises Químicas}

\subsubsection{Do basalto al terado}

Este material foi utilizado neste trabalho, nu ma tentativa de caracterizá-1o como um melhorador de solo. E constituído predominantemente de nontronitas na sua fração argila, e a Tabela 3 mostra os teores dos principais elementos químicos, para fins de fertilidade, obtidos pela análise quími ca de rotina.

Os resultados da análise do basalto alterado mostram que os teores dos elementos nutrientes cálcio e magnésio ocupam $85,6 \%$ dos sítios de troca enquanto que o potássio deve ser mais dificilmente cedido à solução do solo, tendo-se em vista as considerações de NYE et alii (1961) e NAFADY(1972) sobre a adsorção e dessorção do potássio em solos com baixo teor neste elemento. 
Os valores mais altos da CTC determinada, em re lação a CTC calculada, revelam a existência de 14 meq/100g de cargas dependentes de $\mathrm{pH}$ concordando com as afirmações de MAES et alii (1979).

A quase total ausência de matéria orgânica nes te material também sugere que a alteração da rocha original tê nha ocorrido fundamentalmente por processo de hidrólise assocí ada ao mecanismo hidrotermal. Dada a pequena intensidade de colorações avermelhadas e a presença do mineral de argila nontronita, que contém o ferro na forma bivalente, exclui-se tam bém, o processo de alteração por oxidação (MASON, 1971).

0 valor da CTC de $80,04 \mathrm{meq} / 100 \mathrm{~g}$ para o mate rial total que contém $70 \%$ de argila, permite-nos avaliar a CTC da fração argila em 114,34 meq/100g se considerarmos nula a CTC das demais frações. O Indice V: apresenta um valor bastan te alto de $86,6 \%$ permitindo prever que os ions $\mathrm{Ca}$ e $\mathrm{Mg}$ sejam facilmente deslocados da fase trocadora para a solução do so 10. De acordo com MIELKNIZUK (1978) essas argilas podem ser classificadas como de alta densidade de carga e, portanto, podem fixar o potássio.

0 teor de fósforo solüvel de $3,74 \mathrm{meq} / 100 \mathrm{~g}$ for nece-nos um valor aproximado de $2,65 \mathrm{~g}$ de $\mathrm{P}_{2} \mathrm{O}_{5} / \mathrm{Kg}$ de material o que é um valoranormalmente alto de fósforo solúvel para esse material geológico, sugerindo interessantes estudos sobre a geoquímica deste elemento em alterações dessa natureza.

De um modo geral os dados das análises químicas 
mostram que o material reüne propriedades que o tornam passí vel de estudos com a finalidade de caracterizä-lo como um me lhorador de solo.

\subsubsection{Do solo}

0 solo escolhido para o experimento de campo $\underline{\text { a }}$ presenta características químicas bem opostas ao material em pregado. A CTC de $3,51 \mathrm{meq} / 100 \mathrm{~g}$, é constituído fundamentalmen te por cargas $\mathrm{pH}$ dependentes dos óxidos de ferro e alumínio e da matéria orgânica. O seu índice de saturação em bases de $21,6 \%$ mostra o seu caráter distrófico, saturado quase que es sencialmente por hidrogênio e alumínio. O teor de matéria orgâa nica é baixo, assim como o valor do pH. O teor de fósforo solū vel apresenta-se em nível médio, o que até certo ponto é sur preendente, em função do baixo valor de pH, ressalvando-se en

- tretanto que, adubações fosfatadas tenham sido executadas pe riodicamente em tal solo. De um modo geral o solo é caracterizado por um baixo potencial químico necessitando de constantes e controladas fertilizações minerais e orgânicas (Tabela 2).

\subsubsection{Do experimento}

As amostras do solo para análises químicas fo ram coletadas nos anos de 1978 e 1979, isto é, um e dois anos após a aplicação do material. Para cada tratamento, foi coleta da uma amostra composta por repetição e após a secagem ao ar e 
peneiramento $(2 \mathrm{~mm})$ foram misturadas quantidades iguais de ca da repetição. Nesta mistura foram realizadas todas as anālises do referido tratamento.

A capacidade de troca cationica do solo que ini cialmente possuia um valor de $3,51 \mathrm{meq} / 100 \mathrm{~g}$, no ano seguinte elevou-se para aproximadamente 4,0 meq/l00g apenas pelo efeito da adubação (Tabela 5) ao mesmo tempo que a matéria orgânica elevou-se de $0,57 \%$ para aproximadamente $0,93 \%$, sugerindo que 0 aumento da CTC tenha sido também devido a elevação do teor de matéria orgânica e não apenas à adubação fosfatada como sugere PIERI (1977). A dose mais alta de basalto alterado aplicado ao solo juntamente com a adubação promoveram um aumento na CTC pa ra valores próximos a $6,5 \mathrm{meq} / 100 \mathrm{~g}$ o que equivale a aproximadamente duas vezes o seu valor inicial (Tabela 5 e Figura23).

Os valores da CTC na coluna $A_{1}$ da Tabela 5 mos tram as diferenças entre os métodos de análise, sendo maiores os resultados obtidos com o método do acetado de cálcio a pH 7,0 , a seguir está o mesmo método a $\mathrm{pH} 5,0$ e por último o méto do do azul de metileno, concordando com as afirmaçōes de Van RAIJ e PEECH (1972) de que as cargas dependentes de pH são tam bém dependentes do ion considerado bem como da sua concentra ção. Os valores da CTC bem mais baixos com o azul de metileno deve-se, portanto, ao fato de ter sido usada uma solução $0,1 \mathrm{~N}$ de azul de metileno enquanto o método do acetato de cálcio usa solução $1 \mathrm{~N}$. Este fato isolado, entretanto, não seria razão sü ficiente para levar à obtenção de valores tão baixos, pois o complexo formado entre o ion molecular do azul de metileno e 
os colóides do solo possui valores de $\mathrm{pK}$ bem menores do que pa ra o ion cálcio. A razão mais evidente para tal fato relacionase ao estado de dispersão incompleta da fração argila do mate rial adicionado, como jâ nos referimos anteriormente, dificultando a penetração do azul de metileno pelo fenômeno de histerese da troca, citada por Van BLADEL e LAUDELOUT (1967) devido as dimensões do ion $(17,0 \times 7,6 \times 3,25 \AA)$ em relação aos espaçamentos das camadas internas das argilas 2:1 (16 \&, Figura 4) como afirmam HANG e BRINDLEY (1970). Não se refere, neste caso, à presença de vermiculita como poder-se-ia supor pela técnica descrita por CHU e JOHNSON (1969).

$\mathrm{Na}$ Tabela 5 os dados da coluna $\mathrm{B}_{1}$, referem-se à CTC após tratamento das amostras com $\mathrm{H}_{2} \mathrm{O}_{2}$ para eliminação da matéria orgânica e o grau de oxidação desse componente do solo é mostrado pelos resultados da análise química contidos na co luna $\mathrm{B}_{2}$. Como pode-se observar a CTC devida à matéria orgânica varia de 1,69 a 2,18 meq/100g de terra (Coluna $C$ da Tabela 5) - que equivale a aproximadamente 55\% da CTC do solo natural, concordando com as afirmações de SIBAND (1972). Tomando-se em consideração os teores de matéria orgânica da coluna A para o ano de 1979 podemos chegar aos resultados de CTC da matéria orgânica que variam de 173,77 a 260,24 meq/100g de m.o. (Tabe1a 5). Essa grande variação na CTC da matéria orgânica levanos a concluir que o teor total de matéria orgânica tem pouco significado do ponto de vista de propriedades coloidais, pois engloba frações da matéria orgânica em vários estágios de humi 
ficação, sugerindo a necessidade de determinação da matéria or gânica apenas na fração coloidal.

Durante o período do ensaio não se observaram variações sensíveis no teor de matéria orgânica no solo, como mostram os dados da coluna $\mathrm{A}_{2}$ da Tabela 5. Entretanto, percebe-se uma certa tendência à elevação do teor médio de matéria orgânica de 0,91\% para $1,13 \%$ do solo sem adição de basalto al terado e para a maior dose de aplicação, respectivamente.

Essa tendência, provavelmente, poderia 'acentuar-se com um tempo mais longo de observação pois a adição do basalto alterado promoveu uma elevação na CTC e consequentemen te da superfície específica do solo propiciando uma maior esta bilidade da matéria orgânica pela formação de complexos estạ veis organo-minerais como se referem Van OLFEN (1962), ALLISON (1973) e PIERI (1977). A elevação dos teores dos elementos nu trientes de um modo geral, pela aplicação de basalto alterado, também deve ter contribuído para esse aumento no teor de maté ria orgânica do solo, provavelmente, pelo maior crescimento ve getal e pelo aumento da atividade microbiológica do solo.

Efeitos muito significativos da aplicação do ba salto alterado no solo são percebidos nos teores de cálcio, que se elevou de 0,6 meq/100g no solo natural para 1,5 meq/100 g com a aplicação da maior dose de basalto alterado. (Tabela 6).

Este aumento no teor de cálcio ocorre sem haver alteração no pH do solo como pode ser observado na Tabela 7 vindo de encontro as proposições de MUNNS (1976) e AYRES(1961), para o aumento no teor de cáłcio necessário à plantas sensí- 

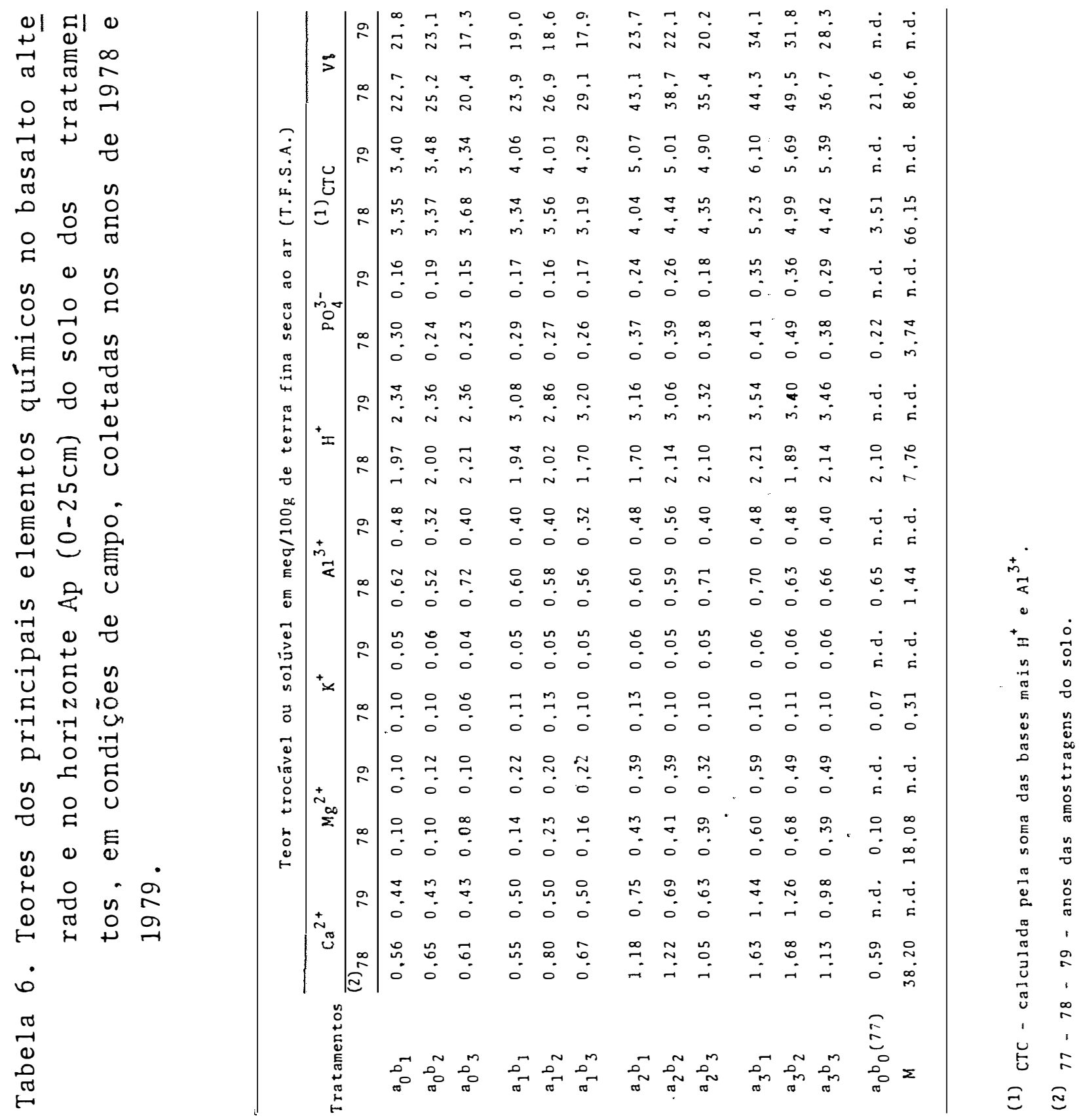
Tabela 7. Determinações analíticas de pH, pHo e ZPNC das amostras do horizonte Ap dos tratamentos (mistura das três repetiçōes) nos anos de 1978 e 1979 e do basalto alterado.

\begin{tabular}{|c|c|c|c|c|c|c|c|c|c|c|c|c|c|c|}
\hline \multirow{3}{*}{$\begin{array}{l}\text { Basal to } \\
\text { Al terado } \\
\text { ton/ha }\end{array}$} & \multirow{3}{*}{ Tratamentos } & \multicolumn{7}{|c|}{$\mathrm{pH}$} & \multicolumn{4}{|c|}{ pHo } & \multicolumn{2}{|c|}{ ZNNC $(79)$} \\
\hline & & \multirow{2}{*}{$\frac{78}{\mathrm{H}_{2} \mathrm{O}}$} & \multicolumn{2}{|c|}{79} & \multirow{2}{*}{$\frac{(1)}{\mathrm{H}_{2} \mathrm{O}}$} & \multicolumn{2}{|c|}{$79 a$} & \multirow[b]{2}{*}{$\mathrm{CaCl}_{2}$} & \multirow[t]{2}{*}{${ }^{(2)} \mathrm{A}$} & \multicolumn{3}{|c|}{$(3)_{B}$} & \multirow[b]{2}{*}{$(4)_{F}$} & \multirow[b]{2}{*}{ G } \\
\hline & & & $\mathrm{H}_{2} \mathrm{O}$ & $\mathrm{KCl}$ & & $\mathrm{KCl}$ & $\mathrm{MpOCl}_{2}$ & & & c & D & E & & \\
\hline & $a_{0} b_{1}$ & 4,70 & 5,03 & 4,02 & 3,50 & 2,77 & 2.60 & 2,55 & 3,60 & 3,20 & 6,75 & n.d. & 2,72 & 2,65 \\
\hline \multirow[t]{3}{*}{0} & $\mathrm{a}_{0} \mathrm{~b}_{2}$ & 4,60 & 5,14 & 4,12 & 3,46 & 2,74 & 2,61 & 2,58 & 3,50 & 3,18 & 5,70 & n.d. & 2,67 & 2,55 \\
\hline & $a_{0} b_{3}$ & 4,50 & 4,97 & 3,97 & 3,52 & 2,77 & 2,57 & 2,59 & 3,40 & 2,87 & 6,60 & 4,40 & 2,61 & 2,40 \\
\hline & $a_{1} b_{1}$ & 4,70 & 4,98 & 4,01 & 3,68 & 2,81 & 2,67 & 2,43 & 3,35 & 3,00 & 6,90 & n.d. & 2,18 & 2,00 \\
\hline \multirow[t]{3}{*}{16} & $a_{1} b_{2}$ & 4,70 & 5,05 & 4,01 & 3,58 & 2.74 & 2,64 & 2,44 & 3,55 & 2,95 & 4,10 & n.d. & 2.18 & 2,00 \\
\hline & $a_{1} b_{3}$ & 4,80 & 5,05 & 3,99 & 3,50 & 2,69 & 2,62 & 2,42 & 3,80 & 3,08 & 3,35 & n.d. & 2,02 & 2,65 \\
\hline & $a_{2} b_{1}$ & 4,80 & 5,06 & 4,06 & 3,53 & $2,66^{\circ}$ & 2,60 & 2,37 & 3,35 & 3,00 & 3,85 & n.d. & 1,97 & 2,20 \\
\hline \multirow[t]{3}{*}{32} & $a_{2} b_{2}$ & 4,80 & 4,98 & 3,90 & 3,55 & 2,65 & 2,58 & 2,40 & 3,30 & 2,80 & 3,90 & n.d. & 1,78 & 2,15 \\
\hline & $a_{2} b_{3}$ & 4,70 & 5,02 & 3,94 & 3,65 & 2,65 & 2,62 & 2,38 & 3,30 & 3,00 & 3,70 & n.d. & 1,71 & 2,30 \\
\hline & $a_{3} b_{1}$ & 4,80 & 5,05 & 3,93 & 3,59 & 2,47 & 2,36 & 2,28 & 3,15 & 3,00 & 3,80 & n.d. & 1,85 & 2,35 \\
\hline \multirow[t]{3}{*}{48} & $a_{3} b_{2}$ & 4,80 & 5,12 & 4,01 & 3,56 & 2,56 & 2,46 & 2,27 & 3,35 & 2,95 & 3,60 & n.d. & 1,82 & 2,20 \\
\hline & $a_{3} b_{3}$ & 4,80 & 5,06 & 3,99 & 3,62 & 2,65 & 2,56 & 2,32 & 3,20 & 3,10 & 3,50 & n.d. & 1,53 & 2.30 \\
\hline & $\mathrm{M}$ & n.d. & 5,77 & 4,35 & 3,00 & 1,80 & 1,97 & \multicolumn{2}{|c|}{$1,55^{(8)}$ n.t. } & n.t. & n.d. & n.d. & $(-8,37)$ & n.t. \\
\hline . & $\mathrm{a}_{0} \mathrm{~b}_{0}$ & 4,70 & n.d. & n.d. & n.d. & n.d. & n.d. & n.d. & n.d. & n.d. & n.d. & n.d. & n.d. & n.d. \\
\hline
\end{tabular}

(1) solo lavado com $\mathrm{HCl} 0,01 \mathrm{~N}$ em seguida com $\mathrm{H}_{2} \mathrm{O}$ até auséncia deCl" (teste $\mathrm{AgNO}_{3}$ ). (2) A-determinado pelo método da adiçāo $(\Delta \mathrm{pH}=0)$. (3) B-determinada pelo método de titulaçāo contínua; C-em solo natural; $D$-em so 10 tratado com $\mathrm{H}_{2} \mathrm{O}_{2}$; E-em solo sem óxidos de ferro livres. (10) F-calculado pela equaçāo $2 \mathrm{PNC}=\mathrm{pHo}+$ $+\frac{{ }_{p}}{1,67.10^{-6} \mathrm{n}^{1 / 2}}$ sendo $\left.{ }_{\mathrm{p}}=-\mathrm{K}^{+}-\mathrm{Cl}^{-}\right]$e pHo o da coluna $\mathrm{A} ; \mathrm{G}-\mathrm{pH}$ onde a adsorçāo $\mathrm{K}^{+}=\mathrm{Cl}^{-}$pelo método gráfico (Fig. 2.0). 
.95 .

veis, o que não poderia ser conseguido apenas com a adição de calcáreo como corretivo da acidez, do alumínio e manganès.

Entretanto, a correspondeência entre o teor de cálcio obtido por análise e a fertilidade real não é usual em oxissolos segundo BRENES e PEARSON (1973) e, de acordo com MUNNS e FOX (1977b) necessita de correlações com o crescimento da planta. Para ELGABALY e WIKLANDER (1949) as plantas de trí go absorvem mais cálcio de solos de baixa CTC com caolinita que daqueles de alta CTC combentonitas e, portanto, as correlações neste caso se fazem ainda mais necessārias.

Ademais, segundo MUNNS e FOX (1977a), a correção da acidez com calcáreo provoca um aumento na CTC fazendo com que o nível de cálcio na solução do solo seja mantido em baixos níveis, havendo um tamponamento desse íon.

O efeito do cultivo, com absorção de nutrien tes pelas plantas mais as perdas por lixiviação, provocou uma diminuição no teor de cálcio de 1978 para 1979, sendo que a re dução foi de $30 \%$ para o solo natural e de apenas $20 \%$ para o so lo sob efeito da maior dosagem de basalto alterado. A relação $\mathrm{Ca}^{2+}$ /cations totais elevou-se de 0,12 no solo natural para 0,22 com a maior dose basalto alterado, passando para níveis mais adequados segundo CARTER et alii (1979). Para o potássio não foram observadas, praticamente, mudanças nos teores trocáveis des se elemento, pelo efeito da adubação e mesmo com a adição de basalto alterado, mantendo-se em níveis baixos em torno de 0,1 emg/100 g de terra. Esta situação é perfeitamente explicável 
pois nem o adubo usado nem o basalto alterado somam quantida des apreciāveis de potássio e aquele contido pelo basalto en contra-se, de acordo com as opiniões de LEE e WIDDOWSON(1977), BLAKEMORE (1973) e NAFADY (1972) o potássio trocável em solos tropicais perde-se rapidamente ou é absorvido pelas plantas,sen do que os solos empobrecidos nesse elemento o fixam com maior energia e o cedem em menor quantidade.

Estes fenômenos podem explicar, também, associa dos indubitavelmente à elevada absorção de potāssio pela canade-açūcar a grande diminuição no conteūdo deste elemento de 0,1 emg/100g de terra para 0,05 emg/100g de terra em apenas um ano de cultivo. (Tabela 6).

As características mineralógicas estruturais dos minerais de argila (nontronitas) presentes no basalto alte rado permitem classificá-las segundo MIELNCZUK (1978) de argi las de alta carga e portanto com possibilidade de fixar potássio por redução do espaçamento basal, como podemos observar nos difratogramas de raios-X (Figura 4) com variação de $16 \AA$ para 12,2 \& por saturação com potássio.

Essa retrogradação do potássio, embora considerada na prática como efeito negativo, na realidade, se conside rada a longo prazo preparam as reservas de potássio como afir mam DAWDY e HUTCHESON (1963), BLANCHET et alii (1965) e ademais, segundo o I.P.I. (1977), o potássio trocável determinado pela anālise do solo não dā informações satisfatórias sobre o nível de potássio prontamente disponível, a menos que relacio- 
nado ao teor e tipo de minerais de argila presentes no solo. Os baixos teores de potássio encontrados tanto para o basalto alterado como para o tratamento com a maior do se tem pouco significado pois, segundo GREWAL e SINGH (1979) os métodos de extração de potássio diferem grandemente entre si e de solo para solo, concluindo-se que os níveis críticos para determinada cultura variam com o método e tipo de solo.

A diferença entre a CTC determinada e a calcula da, para o basalto alterado, em parte, pode ser explicada por esta variação na extração do potássio.

Por outro lado, considerando-se que os solos tropicais, altamente intemperizados, praticamente não contém minerais de reserva para os nutrientes, principalmente para o potássio,podemos aventar uma possibilidade de utilização desse material enriquecido em potássio, através da sua preparação por troca iônica com sais de potássio, obtendo-se um produto de menor solubilidade que os seus sais.

O magnésio ê um elemento que encontra-se, nor malmente, em baixos teores nos solos tropicais altamente intem perizados, e o presente caso não se faz exceção, a despeito de ter sofrido duasou tres aplicações de calcáreo dolomítico em anos que antecederam o experimento. Entretanto, a aplicação de basalto alterado elevou o teor de magnésio trocável de 0,1 emg/l00g de terra no solo natural para 0,6 emg/l00g de terra, sendo o elemento que alcançou maior aumento porcentual, com a dosagem mais alta aplicada (Tabela 5). 
No que se refere a adubação, as doses aplicadas, praticamente não interferiram nos teores de magnésio tro cável como pode-se observar pelos dados das colunas $b_{1}, b_{2}$ e $\mathrm{b}_{3}$ da Tabela 8 para o elemento.

Os teores de magnésio trocável no solo, pratica mente, não sofreram variações com o cultivo, entre os anos de 1978 e 1979. O processo de colheita da cana-de-açūcar através da queima da palha e a incorporação dos ponteiros da planta, restituem grande parte do magnésio absorvido pelas mesmas, o que explica em parte, a manutenção do nível desse elemento no solo.

A despeito das observações de CHRISTENSON e SOLL (1978) de que em alguns solos arenosos a absorção de magnésio pelas plantas não se correlaciona nem com o seu teor tro cável e nem com o teor total, mas sim com a composição mineralógica da fração argila média, em parte também afirmado por LONGSTAFF e GRAHAN (1951), SALMON e ARNOLD (1963) e RICE e KAM PRATH (1968), a elevação do teor de magnésio obtida no presente trabalho provocou alterações nas relações iônicas do solo para valores mais adequados segundo as preconizações de CARTER et alii (1979). Os valores das relações iônicas $\mathrm{Ca}^{2+} / \mathrm{Mg}^{2+}$ so freu um aumento, com a aplicação do basalto alterado, passando de 0,2 no solo natural para 0,5 para as maiores doses aplicadas, valor este que situa-se em posição intermediäria aos li mites propostos por CARTER et alii (1979).

As diversas dosagens de basalto alterado aplica 
.99 .

Tabela 8. Média dos teores dos principais elementos químicos, por fator, no horizonte $A p(0-25 \mathrm{~cm})$ do solo e dos tratamentos em condições de campo nos anos de 1978 e 1979.

Tratamentos

$\begin{array}{lllllll}a_{1} & a_{2} & a_{3} & a_{4} & b_{1} & b_{2} & b_{3}\end{array}$

\begin{tabular}{|c|c|c|c|c|c|c|c|c|c|}
\hline & $\mathrm{Ca}^{2+}$ & $\begin{array}{l}78 \\
79\end{array}$ & $\begin{array}{l}0,60 \\
0,43\end{array}$ & $\begin{array}{l}0,67 \\
0,50\end{array}$ & 0,69 & $\begin{array}{l}1,56 \\
1,22\end{array}$ & $\begin{array}{l}0,98 \\
0,78\end{array}$ & $\begin{array}{l}1,09 \\
0,72\end{array}$ & $\begin{array}{l}0,88 \\
0,63\end{array}$ \\
\hline Teor & $\mathrm{Mg}^{2+}$ & $\begin{array}{l}7.8 \\
79\end{array}$ & $\begin{array}{l}0,09 \\
0,11\end{array}$ & $\begin{array}{l}0,18 \\
0,21\end{array}$ & $\begin{array}{l}0,41 \\
0,37\end{array}$ & $\begin{array}{l}0,59 \\
0,52\end{array}$ & $\begin{array}{l}0,32 \\
0,33\end{array}$ & $\begin{array}{l}0,35 \\
0,30\end{array}$ & $\begin{array}{l}0,26 \\
0,28\end{array}$ \\
\hline $\begin{array}{c}\text { trocável } \\
\text { em }\end{array}$ & $\mathrm{K}^{+}$ & $\begin{array}{l}78 \\
79\end{array}$ & $\begin{array}{l}0,09 \\
0,05\end{array}$ & $\begin{array}{l}0,11 \\
0,05\end{array}$ & $\begin{array}{l}0,11 \\
0,05\end{array}$ & $\begin{array}{l}0,10 \\
0,06\end{array}$ & $\begin{array}{l}0,11 \\
0,05\end{array}$ & $\begin{array}{l}0,11 \\
0,05\end{array}$ & $\begin{array}{l}0,09 \\
0,05\end{array}$ \\
\hline $\begin{array}{l}\text { meq } / 100 \mathrm{~g} \\
\text { T.F.S.A. }\end{array}$ & $\mathrm{Al}^{3+}$ & $\begin{array}{l}78 \\
79\end{array}$ & $\begin{array}{l}0,62 \\
0,40\end{array}$ & $\begin{array}{l}0,58 \\
0,37\end{array}$ & $\begin{array}{l}0,63 \\
0,48\end{array}$ & $\begin{array}{l}0,66 \\
0,45\end{array}$ & $\begin{array}{l}0,63 \\
0,46\end{array}$ & $\begin{array}{l}0,58 \\
0,44\end{array}$ & $\begin{array}{l}0,66 \\
0,38\end{array}$ \\
\hline & $\mathrm{H}^{+}$ & $\begin{array}{l}78 \\
79\end{array}$ & $\begin{array}{l}2,06 \\
2,35\end{array}$ & $\begin{array}{l}1,89 \\
3,05\end{array}$ & $\begin{array}{l}1,98 \\
3,18\end{array}$ & $\begin{array}{l}2,08 \\
3,47\end{array}$ & $\begin{array}{l}2,00 \\
3,03\end{array}$ & $\begin{array}{l}2,01 \\
2,92\end{array}$ & 3,09 \\
\hline $\begin{array}{l}\text { Teor } \\
\text { solüvel } \\
\text { em } \\
\text { meq } / 100 \mathrm{~g}\end{array}$ & $\mathrm{PO}_{4}^{-}$ & $\begin{array}{l}78 \\
79\end{array}$ & $\begin{array}{l}0,27 \\
0,17\end{array}$ & $\begin{array}{l}0,27 \\
0,17\end{array}$ & $\begin{array}{l}0,38 \\
0,23\end{array}$ & $\begin{array}{l}0,43 \\
0,33\end{array}$ & $\begin{array}{l}0,34 \\
0,23\end{array}$ & $\begin{array}{l}0,35 \\
0,24\end{array}$ & $\begin{array}{l}0,31 \\
0,20\end{array}$ \\
\hline
\end{tabular}


das ao solo não provocam alterações apreciáveis no teor de alu mínio trocável, variando apenas nos períodos analisados (Tabelas 6 e 8). Estes resultados estão perfeitamente dentro do esperado uma vez que o basalto alterado possui um pequeno teor de alumí nio trocável $(1,44 \mathrm{emg} / 100 \mathrm{~g})$ em relação à sua CTC $(80,04$ emg/ $100 \mathrm{~g})$. E oportuno observar-se que este pequeno teor relativo de alumínio trocável neste material com alta proporção de argi las 2:1 está de acordo com SCHWERTMAN e JACKSON (1964) de que a maior parte dos ions hidroxi-alumínio não podem ser extraí dos por sal neutro não tamponado, tal como o método usado no presente trabalho. Contudo, esta forma de alumínio, provavelmen te, deve estar presente fazendo parte da acidez titulável como sugere KAPOOR e GOSWAMI (1978) que também a considera como componente da CTC devida às cargas pH-dependentes. Na forma de hidróxido de alumínio encontra-se polimerizado situando-se nas intercamadas de argila como afirmam RICH (1960), SHEN e RICH (1962) e COLEMAN e THOMAS (1964) não sendo extráivel por sal neutro e bloqueando cargas para adsorção de outros ions. Os altos teores de argilas $2: 1$ podem, também, fornecer por dissolução, quantidades de sílica (NOVAK e ČICEL, 1978), suficien tes para complexar boa parte do alumínio como sugerem HER BILLON et alii (1977) .

Os níveis de adubação aplicados ao solo pratica mente não interferiram nos teores de alumínio trocável no ano de 1978, contudo, para o ano de 1979 parece haver uma tendência de manutenção de teores mais elevados desse elemento para 
as dosagens mais altas de adubo. A diminuição do teor de alumí nio trocável de 1978 para 1979, pode também ser explicada por reações de precipitação entre o alumínio e o fósforo solúvel, acarretando uma diminuição nos teores deste último, o que é con firmado pelos dados da Tabela E. A discreta elevação do pH, pa ra o mesmo período, também pode ter sido a causa da neutraliza ção de parte do alumínio trocävel como comentam SCHWERTMANN e JACKSON (1963 e 1964), VIOLANTE e VIOLANTE (1973) e DIXIT (1979) .

A elevação do teor de fósforo solúvel com a $\underline{a}$ plicação de basalto alterado foi um dos efeitos mais importantes observados neste trabalho. No ano de 1978 os dados mostram uma elevação de 0,27 emg/l00g para o solo sem aplicação de ba salto para $0,43 \mathrm{emg} / 100 \mathrm{~g}$ para o tratamento com a maior dosagem aplicada, o que representa um aumento de $60 \%$ no teor desse ele mento passando de nível médio para nível alto. Do ano de 1978 para 1979 observa-se uma diminuição geral em todos os tratamen tos em 0,1 emg/100g, obtendo-se uma relação de $1: 2$ entre o so lo sem aplicação e aquele com aplicação da maior dosagem de ba salto alterado. (Tabelas 6 e 8 ).

Essa elevação no teor de fósforo solúvel de 0,27 para $0,43 \mathrm{emg} / 100 \mathrm{~g}$ equivale a uma aplicação de $300 \mathrm{Kg}$ de $\mathrm{P}_{2} \mathrm{O}_{5}$ por hectare. Entretanto, quando se considera o teor de 3,74 emg/l00g de $\mathrm{PO}_{4}^{3-}$ encontrado na análise do basalto aplicado, chegamos ao valor de equivalencia de apenas $108 \mathrm{Kg}$ de $\mathrm{P}_{2} \mathrm{O}_{5}$ por hectare, revelando que aproximadamente a $192 \mathrm{Kg} \mathrm{P}_{2}{ }^{0} 5$ foram 
liberados do solo por efeito da reação entre o basalto altera do e o solo.

Esses efeitos devem, fatalmente, ser devidos à reações entre a sílica solúvel e as superfícies dos óxidos e hidróxidos de ferro e alumínio, liberando o fosfato adsorvido, como propõem OBIHARA e RUSSEL (1972) e HERBILLON et alii(1977) ou ainda como sugere GAUR (1969).

Praticamente, pouca ou quase nenhuma variação é observada nos teores de fósforo solúvel por influência da adubação aplicada, equivalente a 32,$0 ; 25,6$ e 19,2 $\mathrm{Kg}$ de $\mathrm{P}_{2}{ }^{0} 5$ por hectare, respectivamente aos niveis $b_{1}, b_{2}$ e $b_{3}$ (Tabela 8).

4.4. Características Eletroquímicas do. Basalto Alterado e do Solo sob Efeito dos Diversos Tratamentos.

4.4.1. $\mathrm{pH}$.

0 indice $\mathrm{pH}$ que mede a atividade dos ions hidro gênio na solução do solo hã muito tempo utilizado como medida da reação do solo, pode também ser empregado para verificar o grau de seletividade dos colóides do solo à adsorção dos dive $\underline{r}$ sos ions.

Os dados da Tabela 7 mostram que não houve va riação no pH do solo no ano de 1978 tanto para os níveis de adubação, quanto para as dosagens de basalto alterado adiciona do ao solo, permanecendo em torno de 4,7 que era o valor do $\mathrm{pH}$ original do solo. Para o ano de 1979 nota-se uma discreta ten 
dência à elevação do pH para valores próximos a 5,0 para todos os tratamentos não se observando influência de nenhum dos fato res, adubação ou basalto alterado. Os valores de pH encontra dos são considerados baixos e, portanto, o solo acha-se em con dições de apresentar sesquióxidos associados aos minerais de argila bloqueando sítios de troca provocando diminuição da CTC tal como sustentam RICH e OBENSHAIN (1955). Ademais, KINNINUR et alii (1975) mostram que os sesquióxidos de ferro e alumínio tambëm sofrem influência do $\mathrm{pH}$ do meio alterando suas capacida des de adsorção de cálcio. Os solos dos tratamentos com aplica ção de basalto alterado, que contêm argilas do tipo $2: 1$, podem apresentar a formação de complexos $\mathrm{Al}(\mathrm{OH})$ - montmorilonita muito estáveis devido ao baixo valor do $\mathrm{pH}$, fato relatado por HSU (1968). Os precipitados de alumínio também podem estar prẹ sentes nas intercamadas dessas argilas, como apontam RICH (1960), SHEN e RICH (1962) e COLEMAN e THOMAS (1964), não sen do extraível com sal neutro e, assim, de acordo com HSU e RICH (1969) e SCHUWERTMANN e JACKSON (1964) constituem-se em um blo queio para a adsorção de outros ions. Estas reações entre as argila $2: 1$ e o alumínio parecem explicar, pelo menos em parte, a diminuição dos teores desse elemento do ano de 1978 para 1979, sem que houvesse ocorrido uma elevação substancial do $\mathrm{pH}$.

Os valores do $\mathrm{pH}$ medido em KCl $1 \mathrm{~N}$ (Tabela 7)são sempre inferiores àqueles medidos em água ( $\Delta \mathrm{pH}$ é negativo)(Tabela 9) o que, segundo Van RAIJ e PEECH (1972), indica que ZPC situa-se abaixo do valor do $\mathrm{pH}$ do solo. Entretanto os valores 


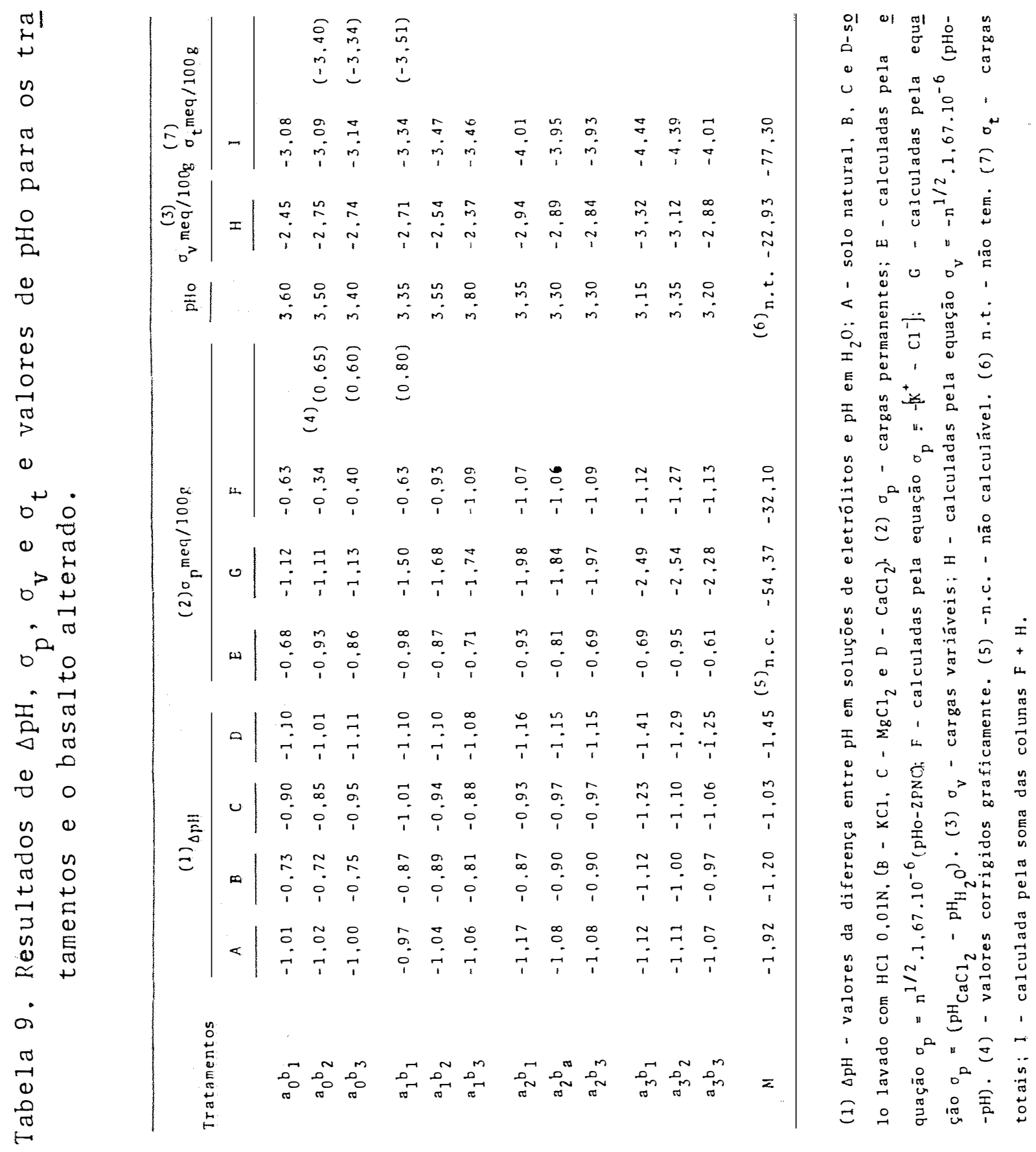


.105 .

absolutos de $(\Delta \mathrm{pH})$ apresentados na coluna A da Tabela 9 não tem o significado de maior ou menor distância entre ZPC e pH emprestados pelos referidos autores, uma vez que se trata de uma diferença entre logarítmos e, portanto, depende da sua po sição. Ainda na Tabela 7, colunas 79a, observamos os valores de $\mathrm{pH}$ dos solos lavados com HCl 0,01N para remoção dos cations que saturam as cargas tornando-os homoionicos saturados com $\mathrm{H}^{+}$. Os valores obtidos em água são muito semelhantes aos valores de pHo (coluna A da mesma Tabela): em solução de eletrolí tos os valores de pH são sempre inferiores à ägua. Entre os eletrólitos podemos estabelecer a seguinte ordem decrescente: $\mathrm{H}_{2} \mathrm{O}>\mathrm{KCl}>\mathrm{MgCl}_{2}>\mathrm{CaCl}_{2}$ para todos os solos à exceção do ba salto alterado. Para este material estabelece-se a sequência: $\mathrm{H}_{2} \mathrm{O}>\mathrm{MgCl}_{2}>\mathrm{KCl}>\mathrm{CaCl}_{2}$.

Através destes dados podemos concluir que tanto para o solo como para o basalto alterado o cálcio é o ion mais eficiente para deslocamento dos ions hidrogênio e, então, dize mos que as superfícies de troca desses sistemas coloidais como um todo apresentam uma maior seletividade por cálcio em rela ção ao hidrogênio, tendo em vista a utilização de um sal neu tro não tamponado. Essa maior energia de retenção do sistema coloidal por cálcio parece ser uma regra mais ou menos geral nos solos, pois este ion sempre ocupa a maior fração das bases presentes. Os resultados aqui obtidos para o basalto contendo quase que essencialmente argilas silicatadas põem em discussão as afirmações de BAWEJA e MAcKEAN (1975) sobre a fraca reten 
ção do cálcio contra o deslocamento por hidrólise dos sítios de cargas pH-dependentes, porém concordam integralmente com MUNNS (1976 e 1977) para os sitios de carga nos humus dos oxis solos que apresentam forte afinidade pelo cálcio. As afirma ções de MATTSON e LARSSON (1946) de que a caolinita possui e nergia de ligação mais alta por ions monovalentes que por ca tions divalentes estão em desacordo com os dados deste trabalho visto que a fração argila destes solos apresenta quase que exclusivamente esse mineral. Entretanto, estas incongruências são elucidadas pelas colocações de RICH e OBENSHAIN (1955) e DAVIDTZ e SUMMER (1965) a respeito da ocorrência de um recobri mento dos minerais de argila por óxidos de ferro constituindose num bloqueio das cargas daqueles minerais que assumem com portamento anômalos em solo ferralíticos. Segundo KINNINURGH et alii (1975) os hidróxidos de ferro e alumínio apresentam ad sorção preferencial por cálcio em relação a ions monovalentes. Van OLFEN (1963) afirma que da mesma forma, a matéria orgânica também pode associar-se as partículas de argila resultando va riações no comportamento dos solos.

Em seguida observamos que o solo segue a ordem da série liotrópica tal como proposto por GIESEKING e JENNY (1936), enquanto que no basalto alterado ocorre uma inversāo entre potássio e magnésio havendo maior afinidade pelo potássio obtendo-se valores de $\mathrm{pH}$ mais baixos. Estes resultados são muito coerentes com as reaçōes desse material no solo promoven do um aumento no teor de magnésio trocável sem, entretanto, cau sar incrementos no teor de potássio. Essa maior afinidade por 
potássio pode ser observada na Figura 25 mostrando que as adi ções crescentes de basalto alterado propiciaram uma maior re tenção de potássio em relação ao cálcio e magnésio.

As diferenças entre o $\mathrm{pH}$ em $\mathrm{H}_{2} \mathrm{O}$ e o pH em solução de eletrólitos não tamponados representam a quantidade de ions hidrogênio deslocados das cargas permanentes do solo. Co mo, no caso, o cálcio foi o elemento que propiciou, um menor valor de pH para todas as amostras as equações que descrevere mos oportunamente serão definidas em função desse elemento, o que, no entanto, não significa que todos os ions hidrogênio te nham sido medidos, mas apenas que o cálcio foi mais eficiente no deslocamento do hidrogênio.

E interessante notar-se que $0 \mathrm{pH}$ de 4,7 para es te solo, constituído em grande parte por colóides com cargas altamente dependentes de $\mathrm{pH}$, e que possui valores de pHo em torno de 3,5 (coluna $A$, Tabela 7), tem em atividade quase que exclusivamente as cargas permanentes, pois como afirmam MUNNS e FOX (1977) a CTC aumenta de duas a tres vezes quando o $\mathrm{pH}$ do solo varia de 4,8 para 7,1. Esta situação nos leva a concluir que o valor da CTC determinada pela soma de cations trocáveis é,em geral, falha e, assim boa parte dos nutrientes, po tássio, cálcio e magnésio encontram-se de uma forma muito láa bil no solo,fazendo parte da solução do solo uma vez que o hí drogênio e o alumínio devem estar retidos com maior energia pe los colóides. 


\subsection{2. pHo (ou ZPC)}

De acordo com a definição de UEHARA e GILLMAN (1980), pHo é o valor de $\mathrm{pH}$ no qual o valor das cargas totais do solo $=\sigma_{p}$,. sendo o ponto em que as cargas variáveis e igual a zero $\left(\sigma_{v}=0\right)$ e a adsorção iônica ocorre às cargas permanentes Outros autores como Van RAIJ e PEECH (1972), PIERI (1977) deno minam o pHo de ZPC (ponto zero de carga) sendo, entretanto, es ta ūltima definição à sistemas onde apenas as cargas pH-dependentes estão presentes. 0 pHo é também o pH que independe da concentração de eletrólitos do meio, isto é, o ponto de cruzamento das curvas em diferentes concentrações.

A composição mineralógica do solo, bem como de toda a fração coloidal do solo interferem marcadamente nos va lores de pHo. Dois métodos são usados na determinção do pHo, sendo um por titulação contínua (SCHWERTMANN e JACKSON, 1963 e DIXIT, 1979) cujos dados encontram-se na coluna A da Tabela 7) e outro chamado método da adição (Van RAIJ e PECCH, 1972; DIXIT, 1979 e UEHARA e GILLMAN, 1980) cujos dados da coluna C referem-se ao solo natural, os da coluna D ao solo tratado com $\mathrm{H}_{2} \mathrm{O}_{2}$ para destruição da matéria orgânica e os da coluna E para o solo sem matéria orgânica e deferrificado.

Os valores do pHo para o solo natural são maio res para o método da adição que para o método da titulação con tínua, sendo resultados inversos aqueles obtidos por \&. DIXIT (1979) para horizontes superficiais de um Hapludalf.

As diferenças entre os métodos devem-se prova 
velmente a vários fatores que podem agir no mesmo sentido ou em sentido contrário. Alguns desses fatores citados por BERUBE (1967) e BLOK e BRUYN (1970) podemos destacar:

i) o tempo de reação no método de adição é mais longo; (ii) no método de titulação contínua os cations presentes no solo podem interferir na posição do pHo, principalmente no $\mathrm{Al}^{3+}$, por não ter sido anteriormente eliminado por lavagem com sal neutro; (iii) erros provenientes das construções gráfí cas no método da adição uma vez que os pontos são muito distan tes e o cruzamento entre as curvas é obtido graficamente.

As Figuras 6,7,8 e 9apresentam as curvas de titulação através do método da titulação contínua e mostram uma maior regularidade gräfica devido ao grande número de pontos obtidos por este método e, as Figuras 10,11,12 e 13 contém as curvas pelo método da adição.

Os dados da Tabela 7 mostram por ambos os métodos (colunas A e C) que os valores de pHo tendem a decrescer com o aumento da dosagem de basalto alterado, devido a eleva ção das cargas permanentes como afirmam Van RAIJ e PEECH(1972) revelando ainda que o basalto alterado não possui pHo.

Os baixos valores obtidos para o pHosãodecorren tes da constituição mineralógica e da composição da fração co loidal não mineral do solo. Os baixos teores de gibbsita (Figu ras $5 a$ e $5 c$ ) e de óxidos de ferro livre (Tabela 1) não produzem valores elevados de pHo (Van RAIJ e PEECH, 1972 e PARKS, 1965) assim como a grande participação da caolinita e da maté- 

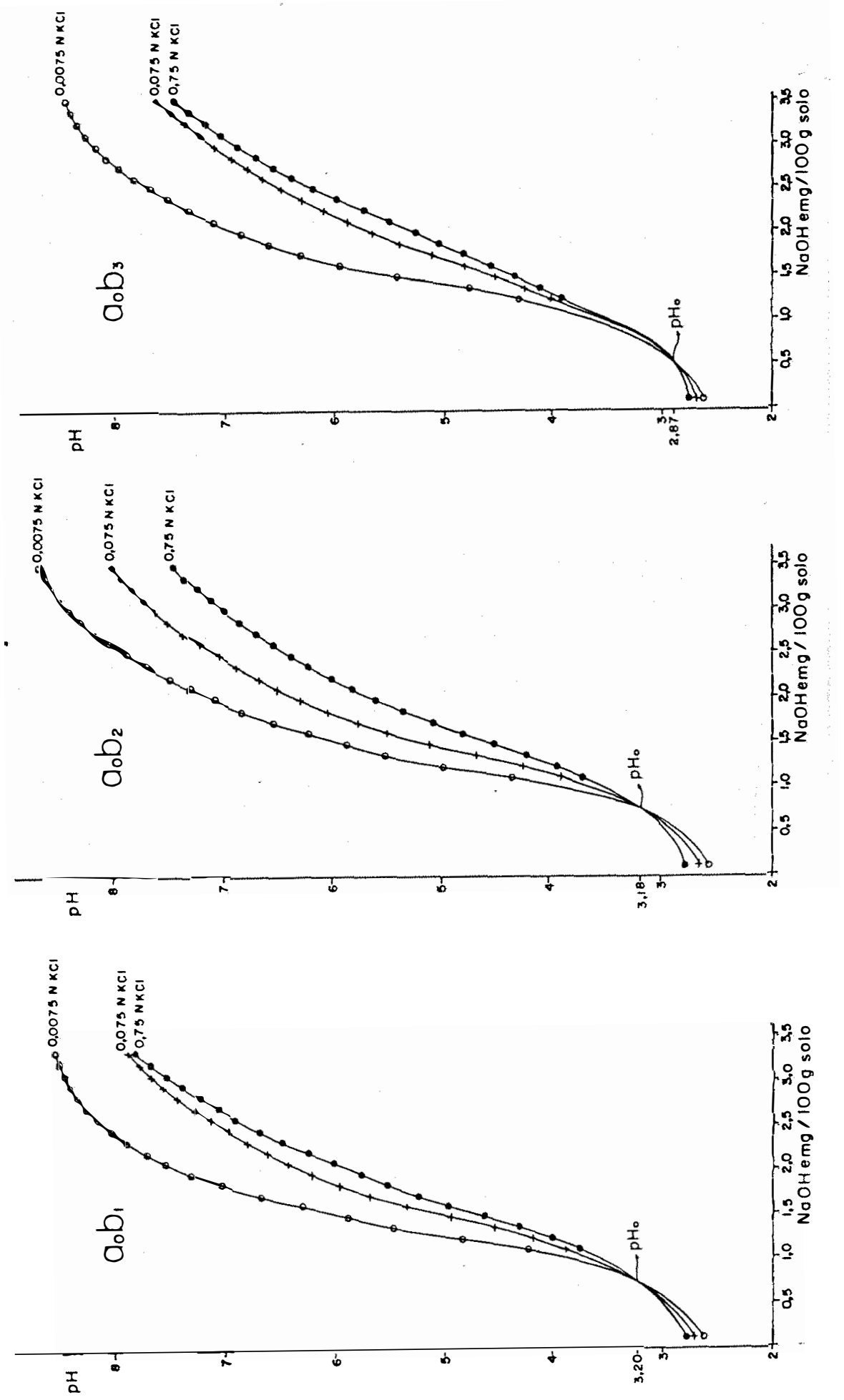

إه

\%

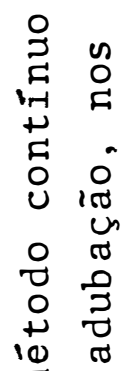

○

त) os

م.

ये $>$

in

t)

范

•

$\begin{array}{lll}5 & 0 & \pi \\ 0 & \pi & \pi \\ + & 0 & 0\end{array}$

مـ

० 00

皆 0

בูป

웜

0

U 的

क

龸

उ 

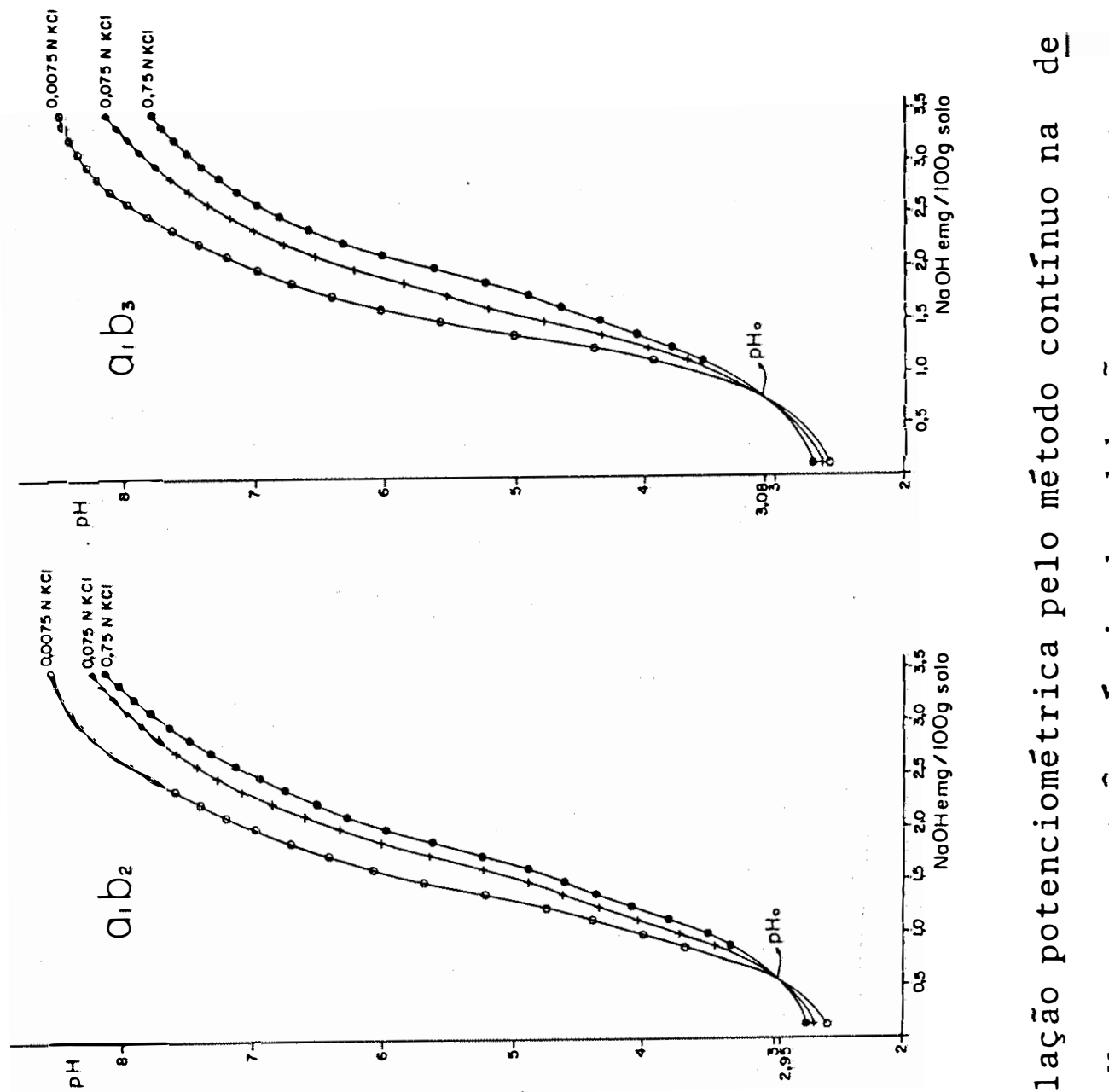

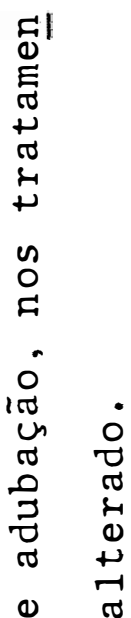

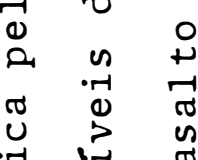

م

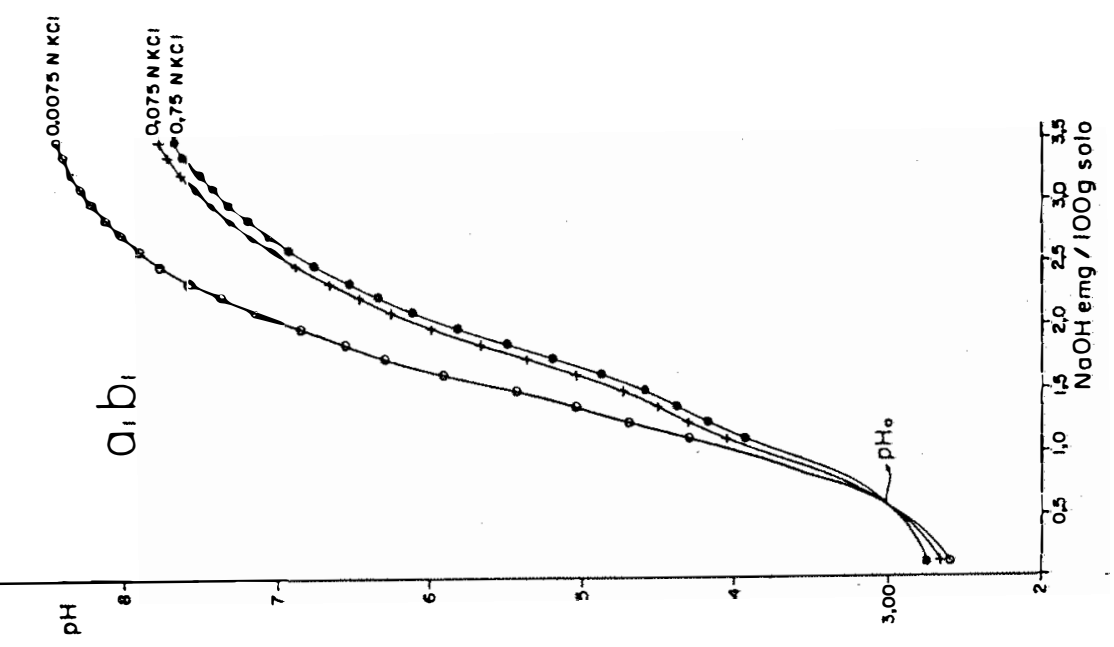

告 为

品

岂

○

م.

i⿱宀⿻⺀大土 0

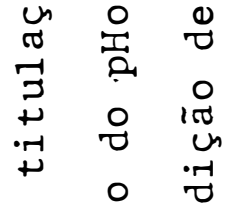

ه

年

总 


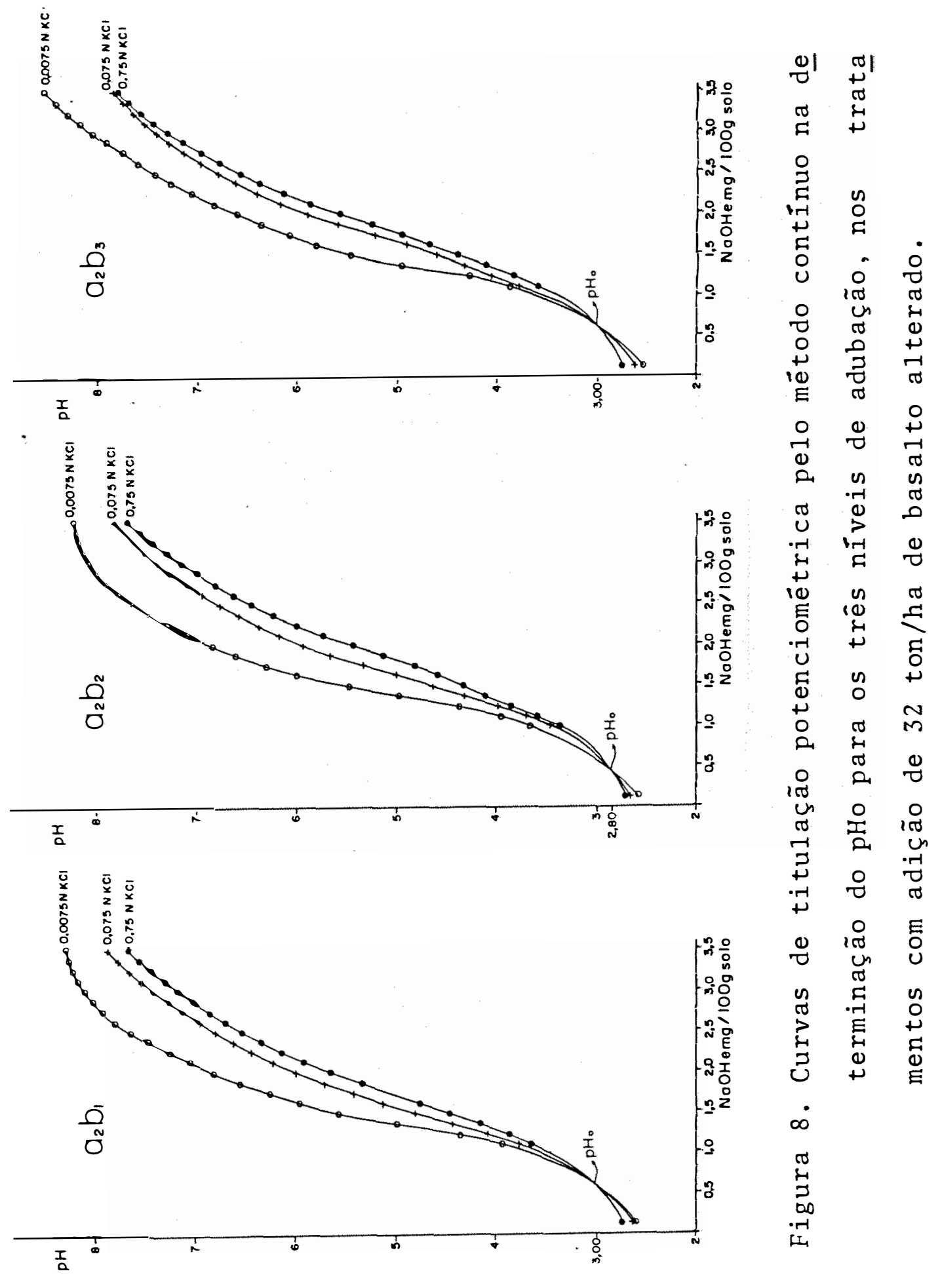



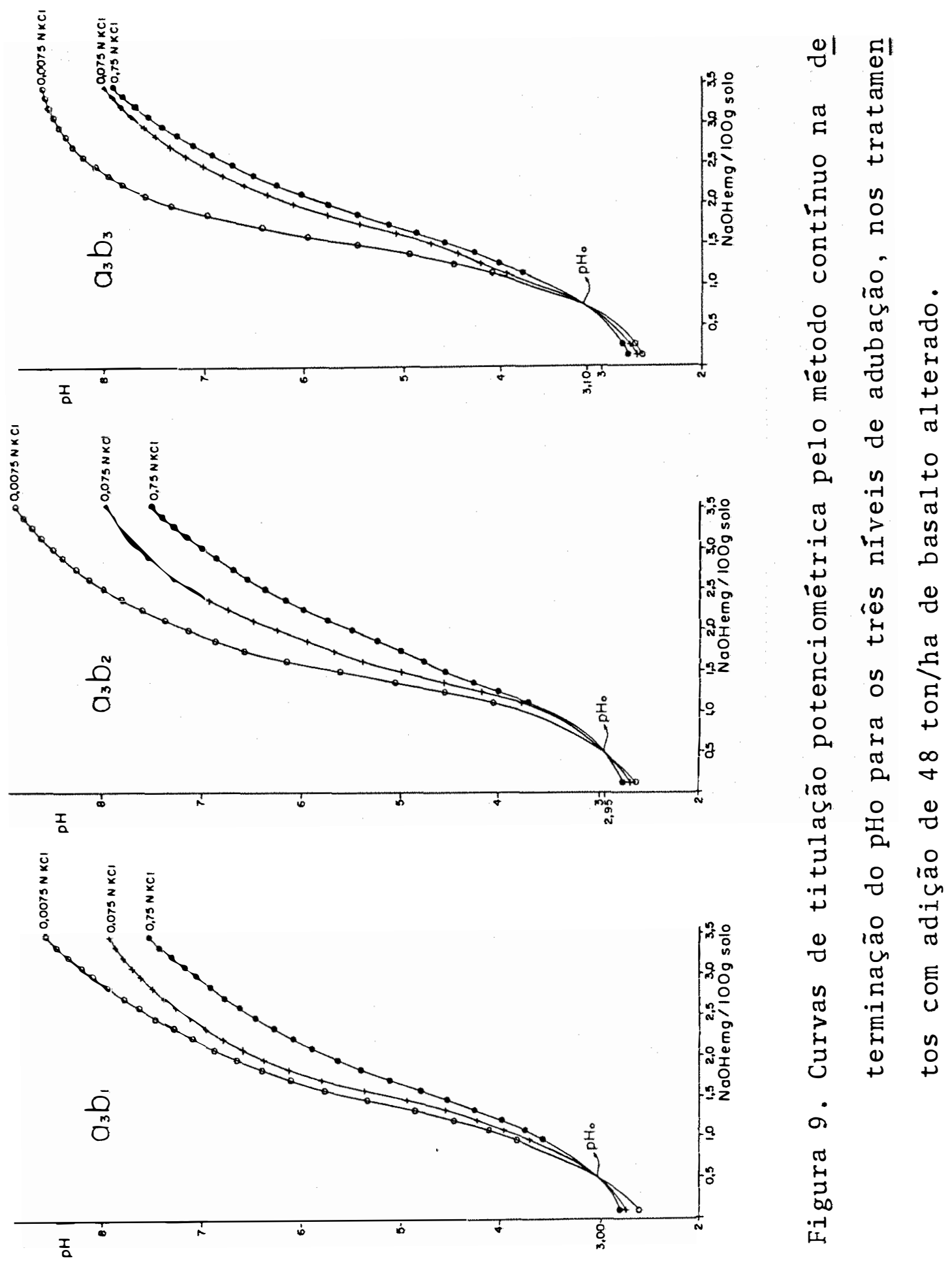
.114.

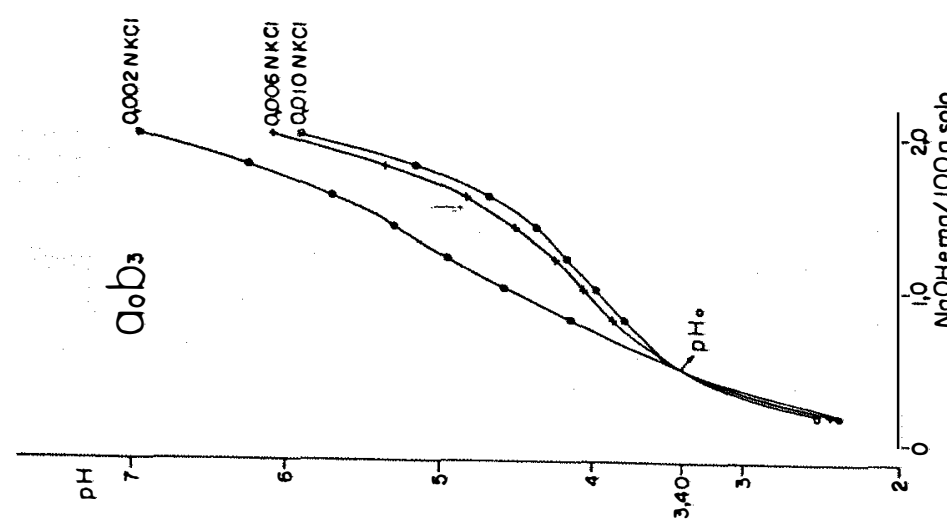

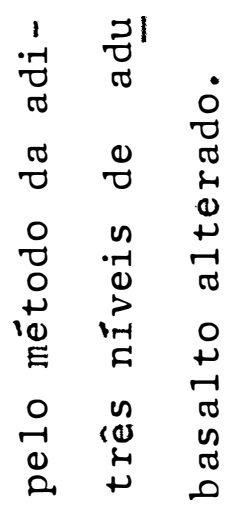

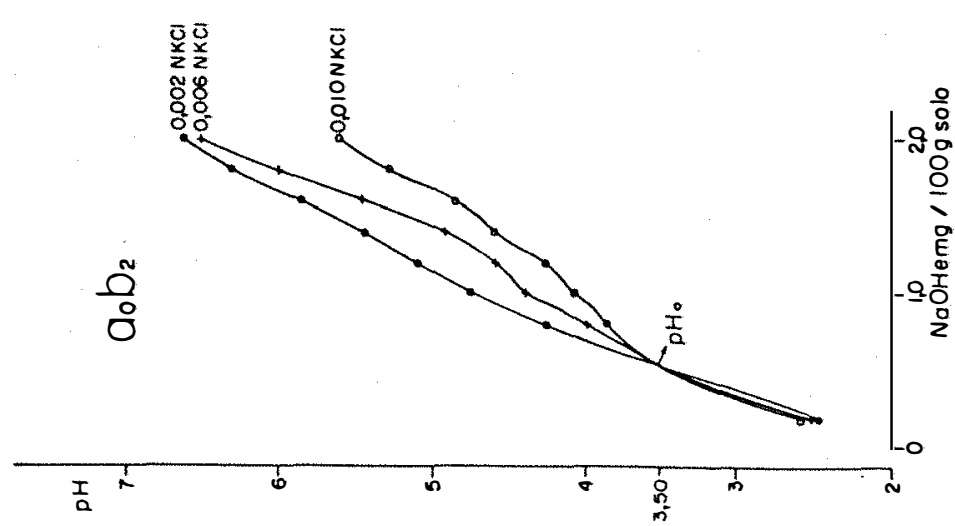

U 0 ข

先 苾

范先

.

$\begin{array}{lll}E & I & E \\ 0 & D & 0 \\ 0 & 0 & n\end{array}$

욤유

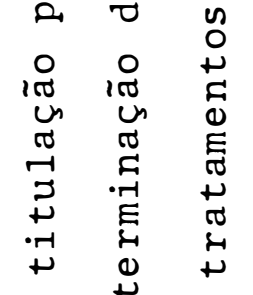

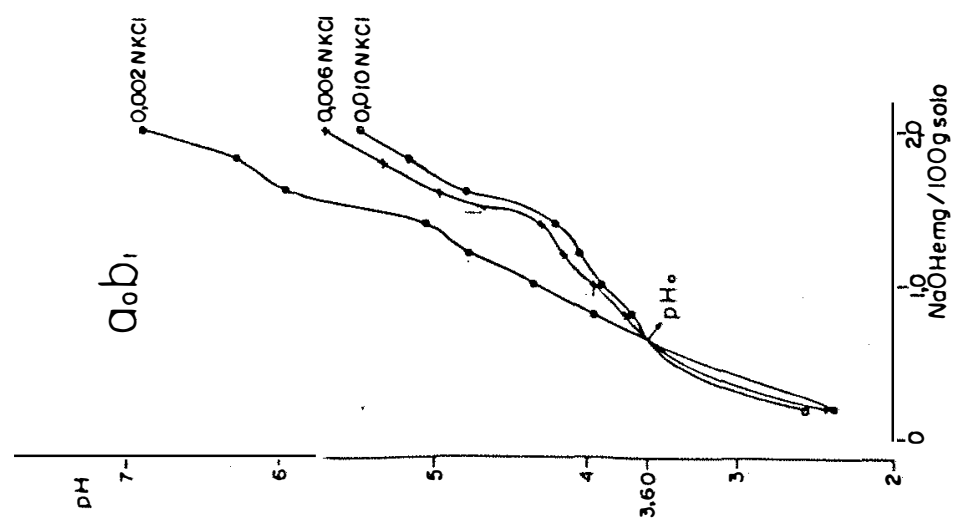

ช

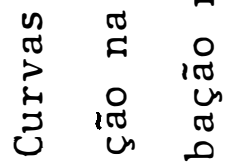

$\stackrel{0}{-1}$

$\pi$
5
0
0.1
1
1 


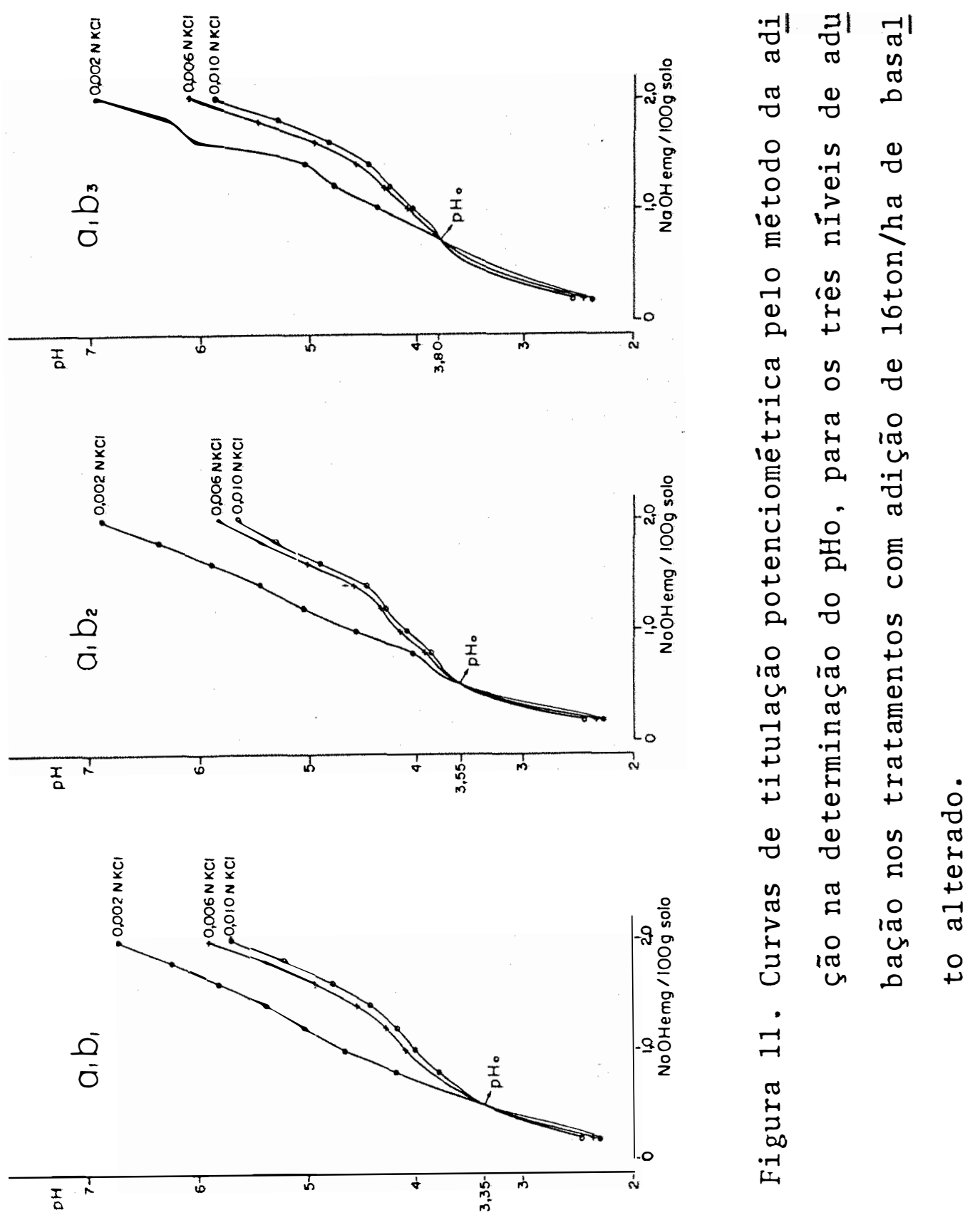


.116.

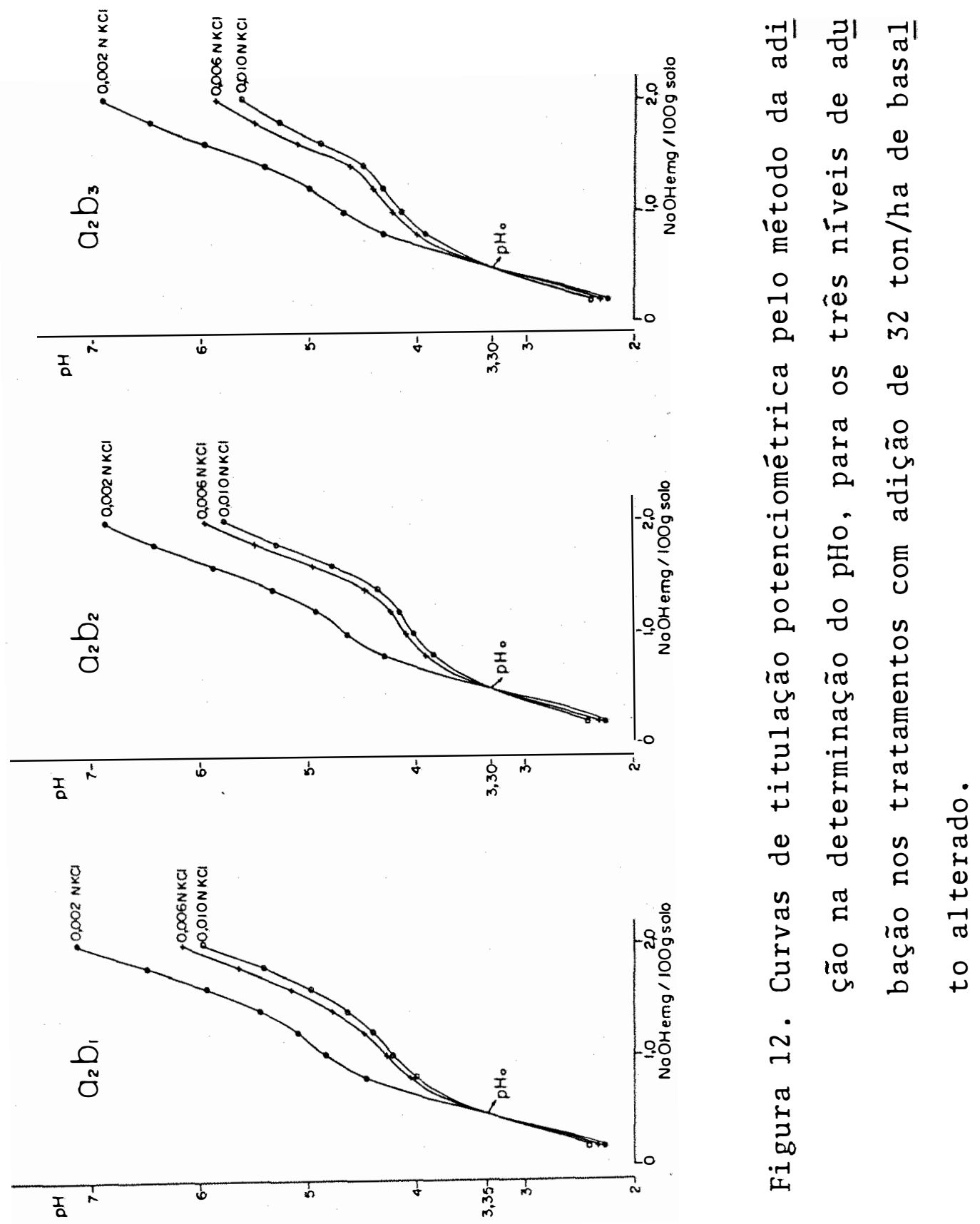


.117.
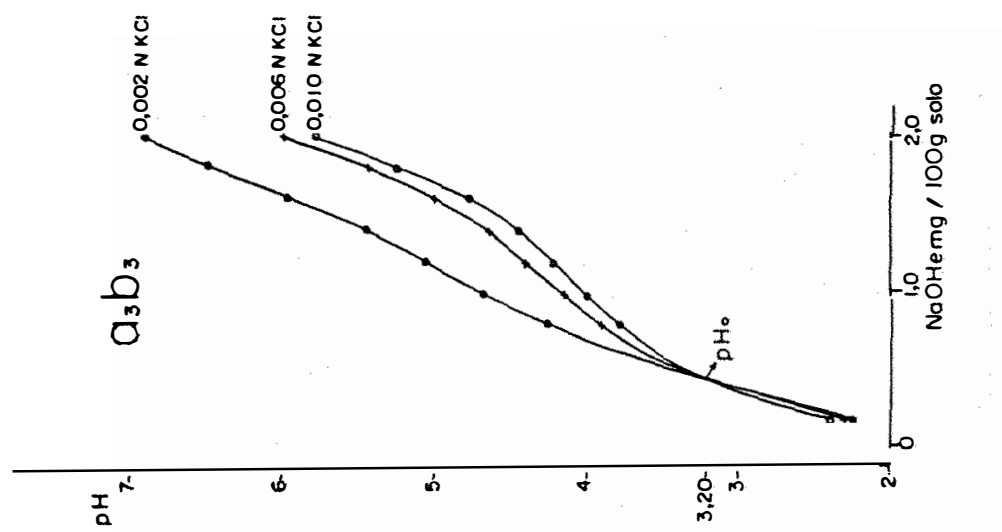

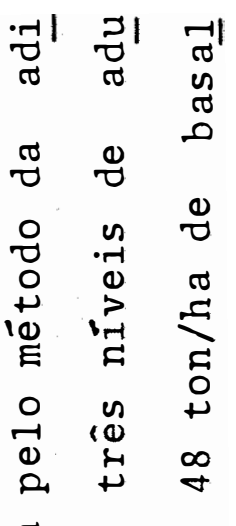

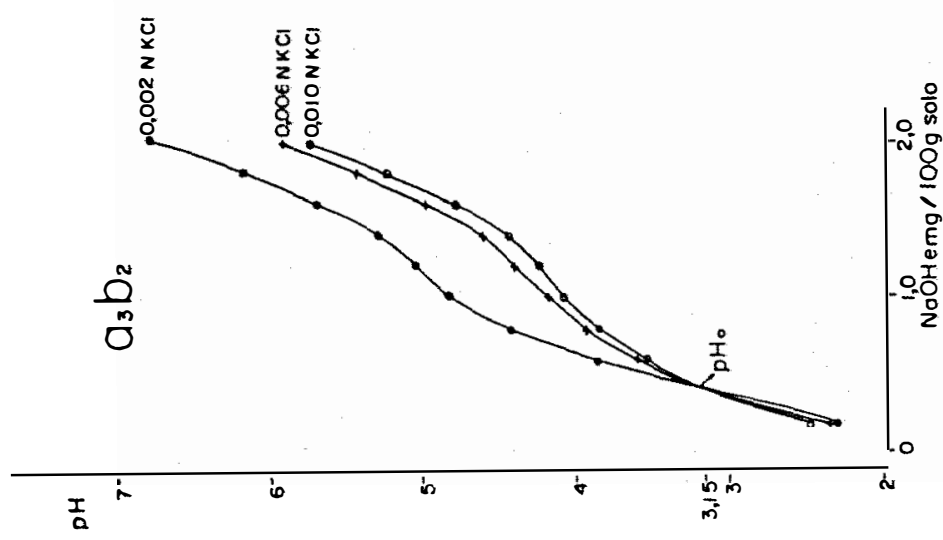

ช 00

.

10

हू م चี

ن 0 \%

党

응ㅇ

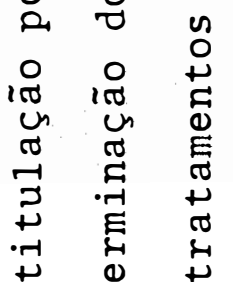

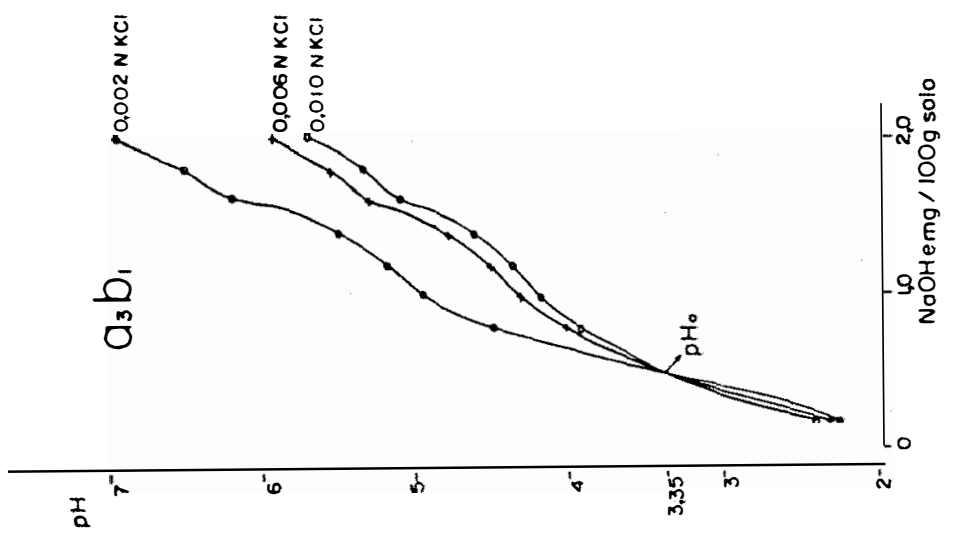

๑)

ข ๘

¿ 0 un

ป ن

m

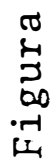


.118 .

ria orgânica nas cargas deste solo tendem a diminuir os valo res de pHo (PARKS et alii, 1967).

Essas afirmações são constatadas, na prática, quando observamos os dados da coluna D da Tabela 7 , onde encon tramos valores bem mais aitos de pHo para os solos que sofre ram oxidação da sua matéria orgânica. (Figuras 14, 15, 16 e 17).

Neste caso acentua-se ainda mais a ordem decres cente de valores de pHo com o aumento das dosagens de basalto alterado, com um grande conteúdo de argilas silicatadas $2: 1$, e que nem sequer possuem pHo (colunas A e C da Tabela 7).

o efeito dos óxidos de ferro livres na posição do pHo pode ser observado pelos dados da coluna E da mesma ta bela, onde o valor do pHo para o solo deferrificado (após oxi dação da m.o.) assume posição intermediária entre o solo natu ral e aquele onde apenas a matéria orgânica foi destruída, mos trando a sua participação no sentido de elevar o valor de pHo, (Figura 18). Como afirmamPARKS et alii (1967) o valor do pHo nos dá uma boa indicação da participação relativa dos diversos elementos do sistema coloidal do solo.

Os dados mostram, também, que não houve, praticamente, influência da adubação nos valores de pHo. (Tabela 2).

4.4.3. Ponto de carga líquida igual a zero (ZPNC ou P CLZ)

O ZPNC é o ponto de carga zero do sistema como um todo e, então, é chamado de ponto de carga líquida igual a 


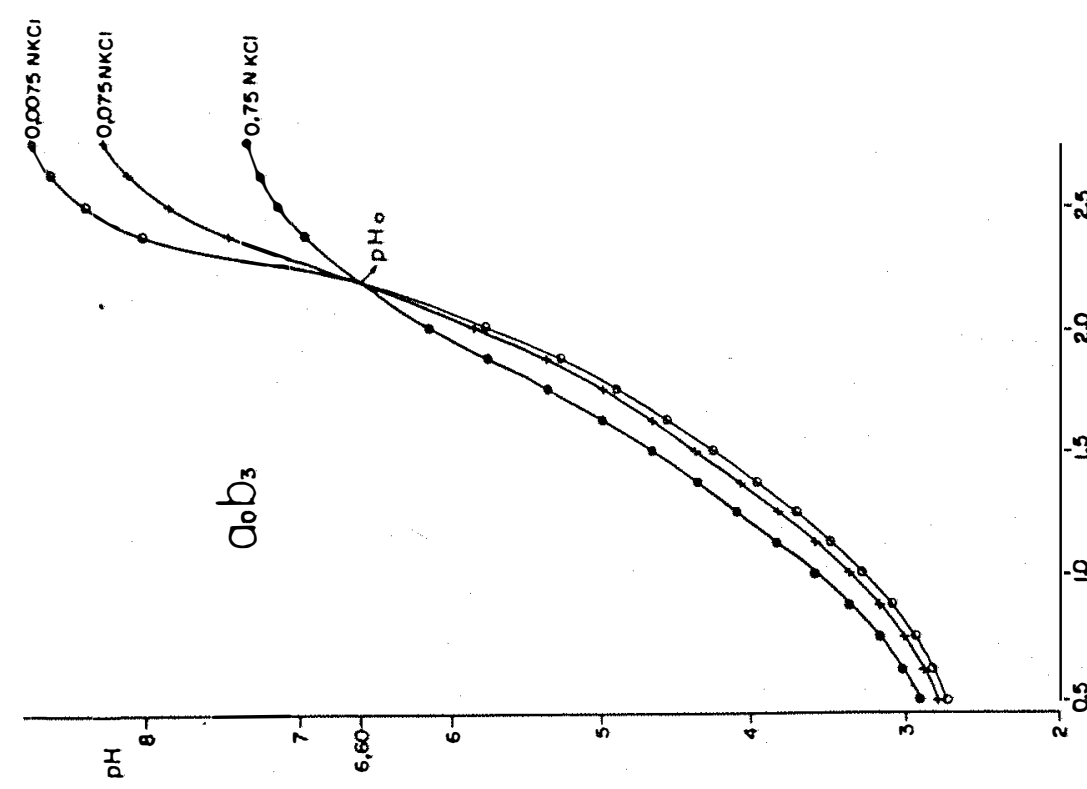

- $0 \underbrace{n} .119$.
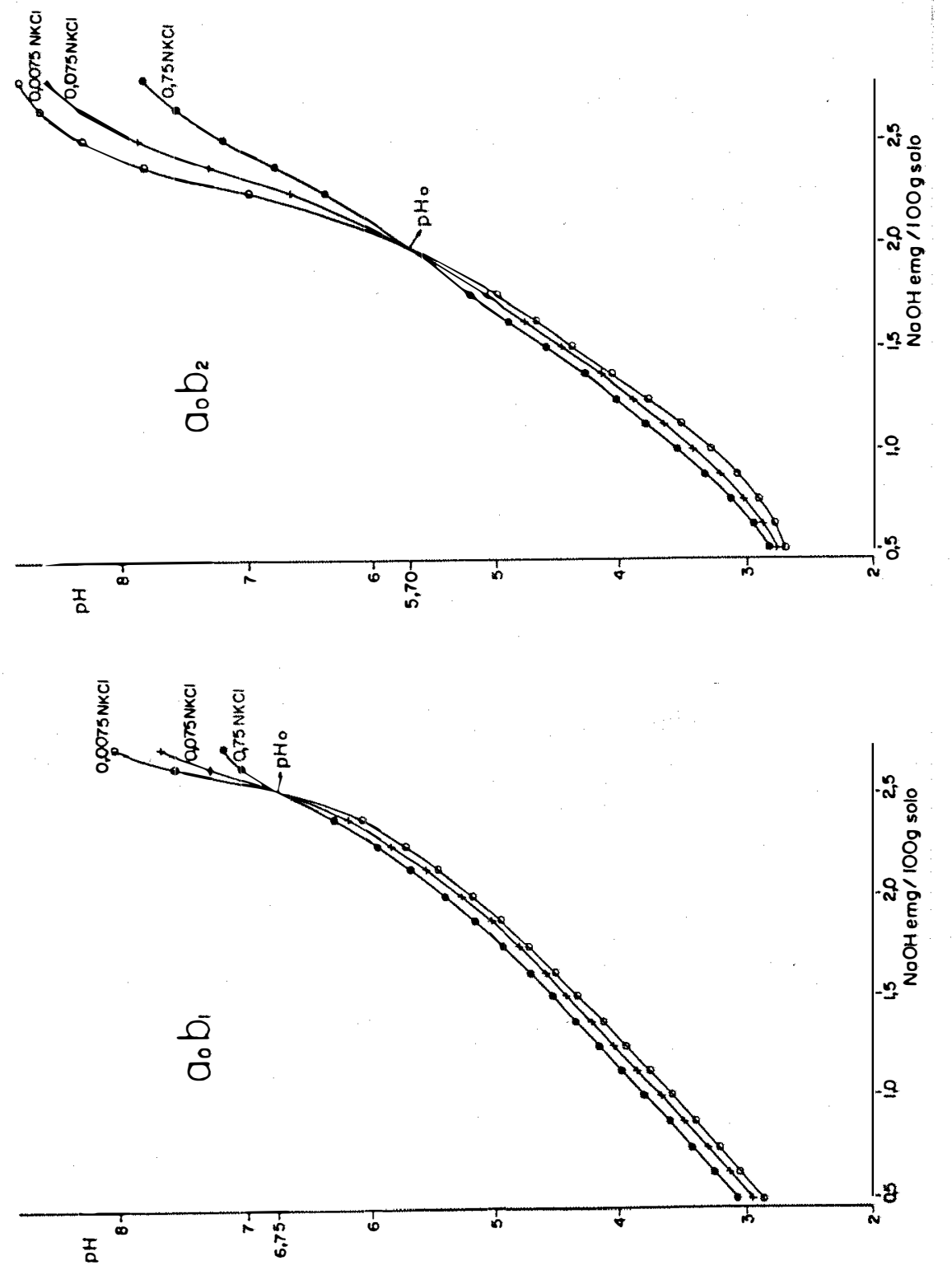

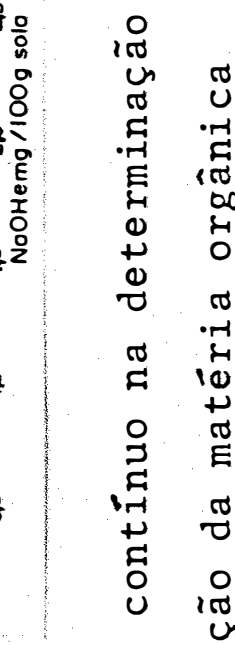

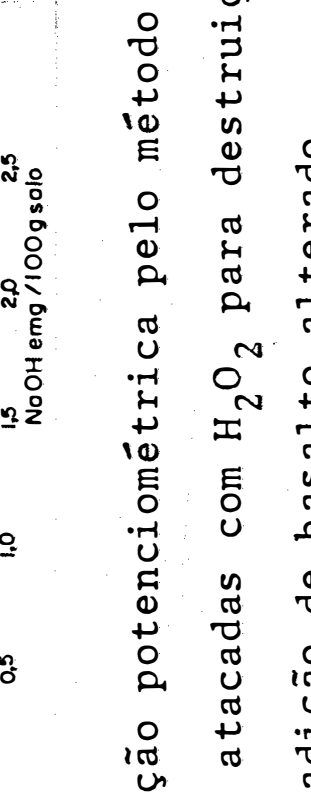

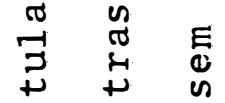

in 0 in

๑

๗

荥

$\dot{\square}$

党

A. 

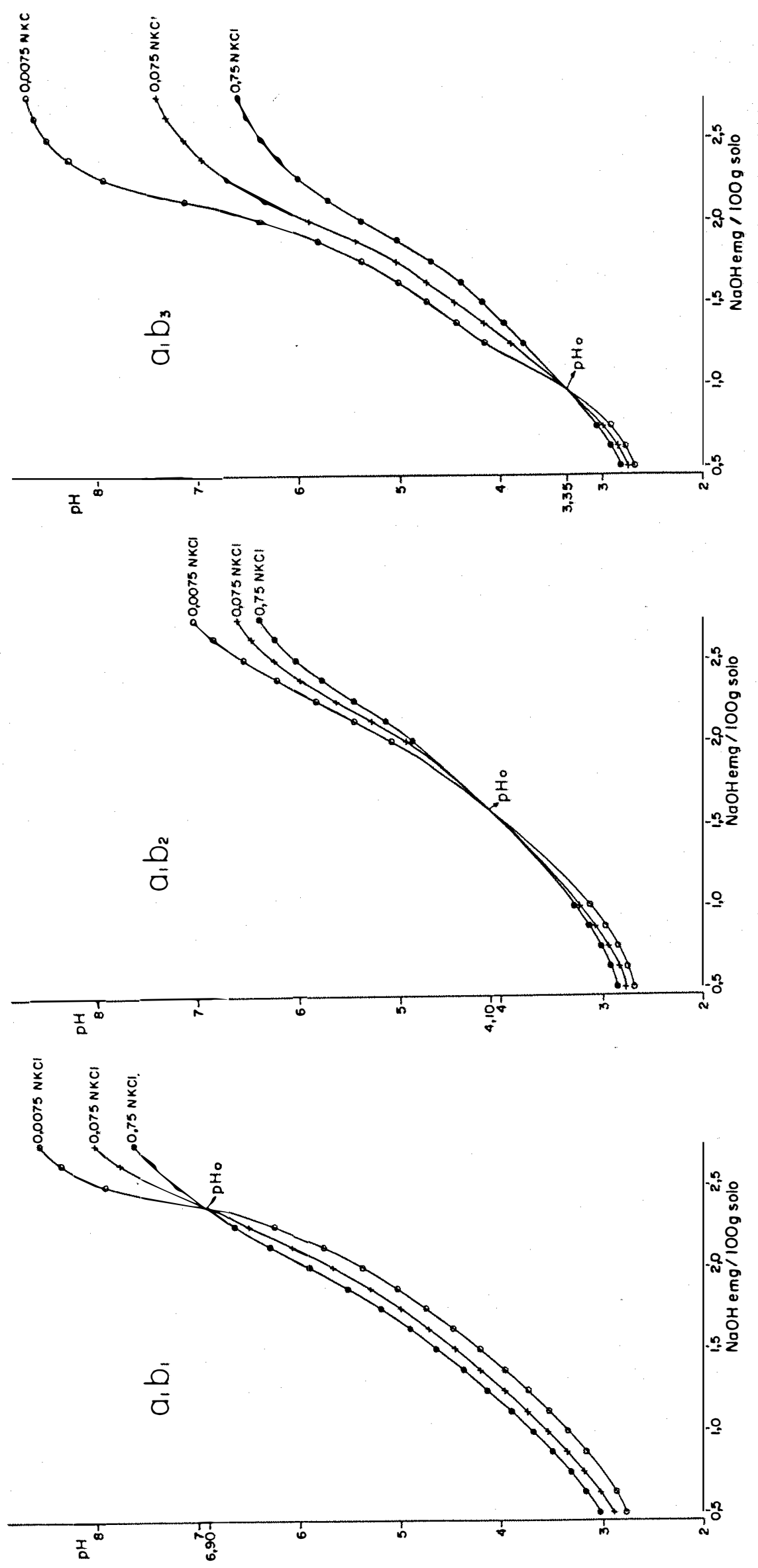

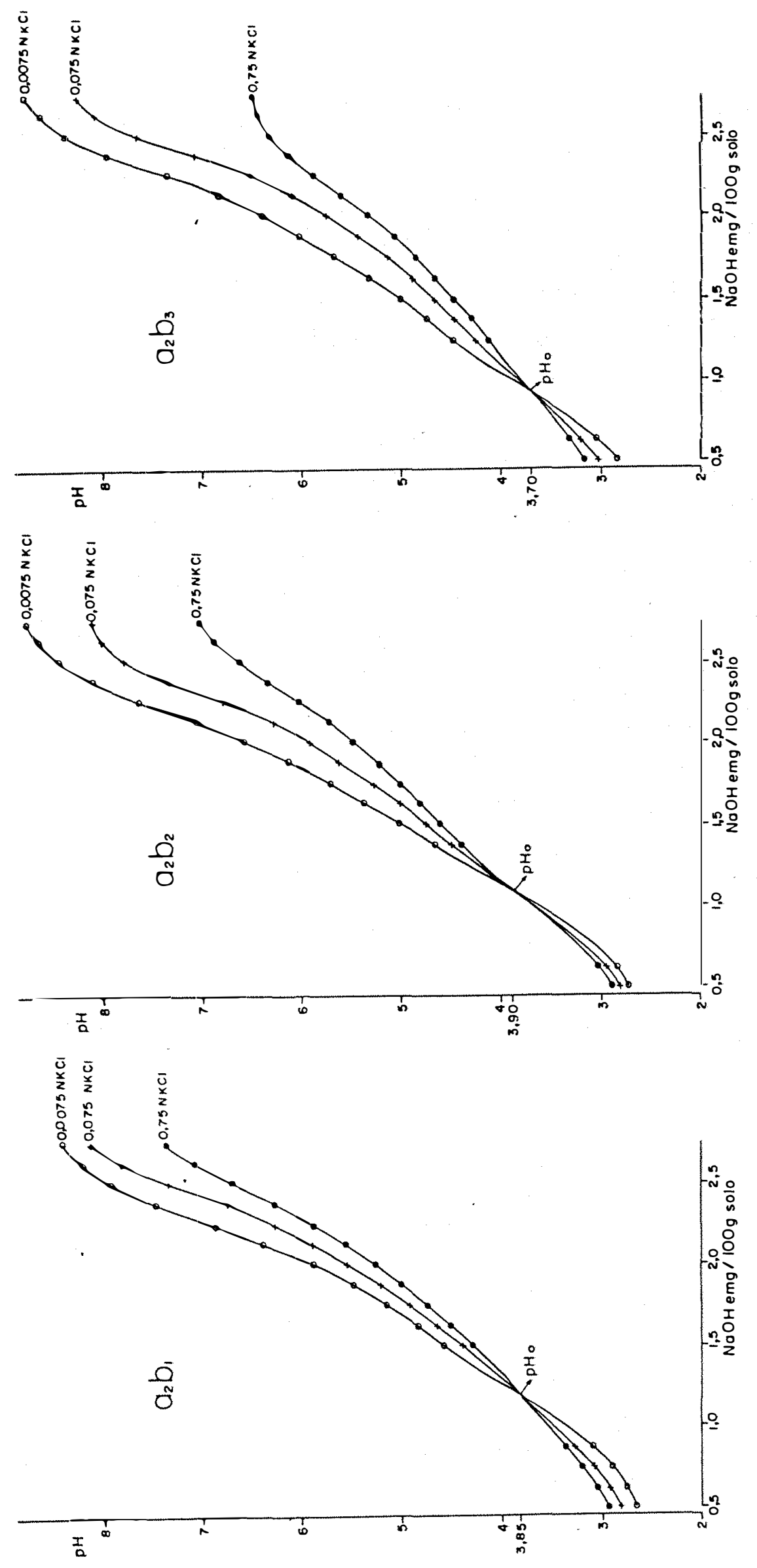

ㅇำ $\stackrel{0}{7}^{.121 .}$

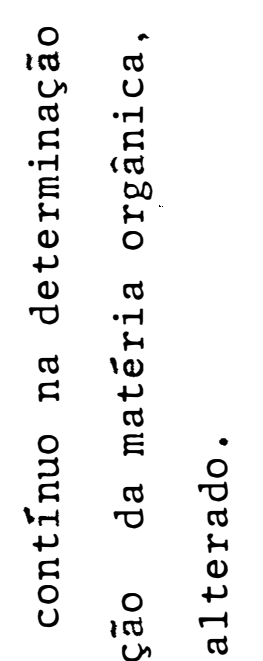

‥-

焉

E

จ

ڤ

(ช)

U 0

出 I

E E $\begin{gathered}E \\ \text { O }\end{gathered}$

先 N

$+$

足

畓

落

+ \&

ฮ

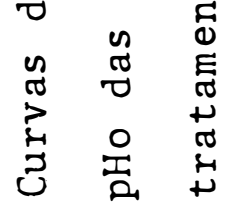

$\stackrel{\circ}{-1}$

$\pi$
5
0
-1
15 


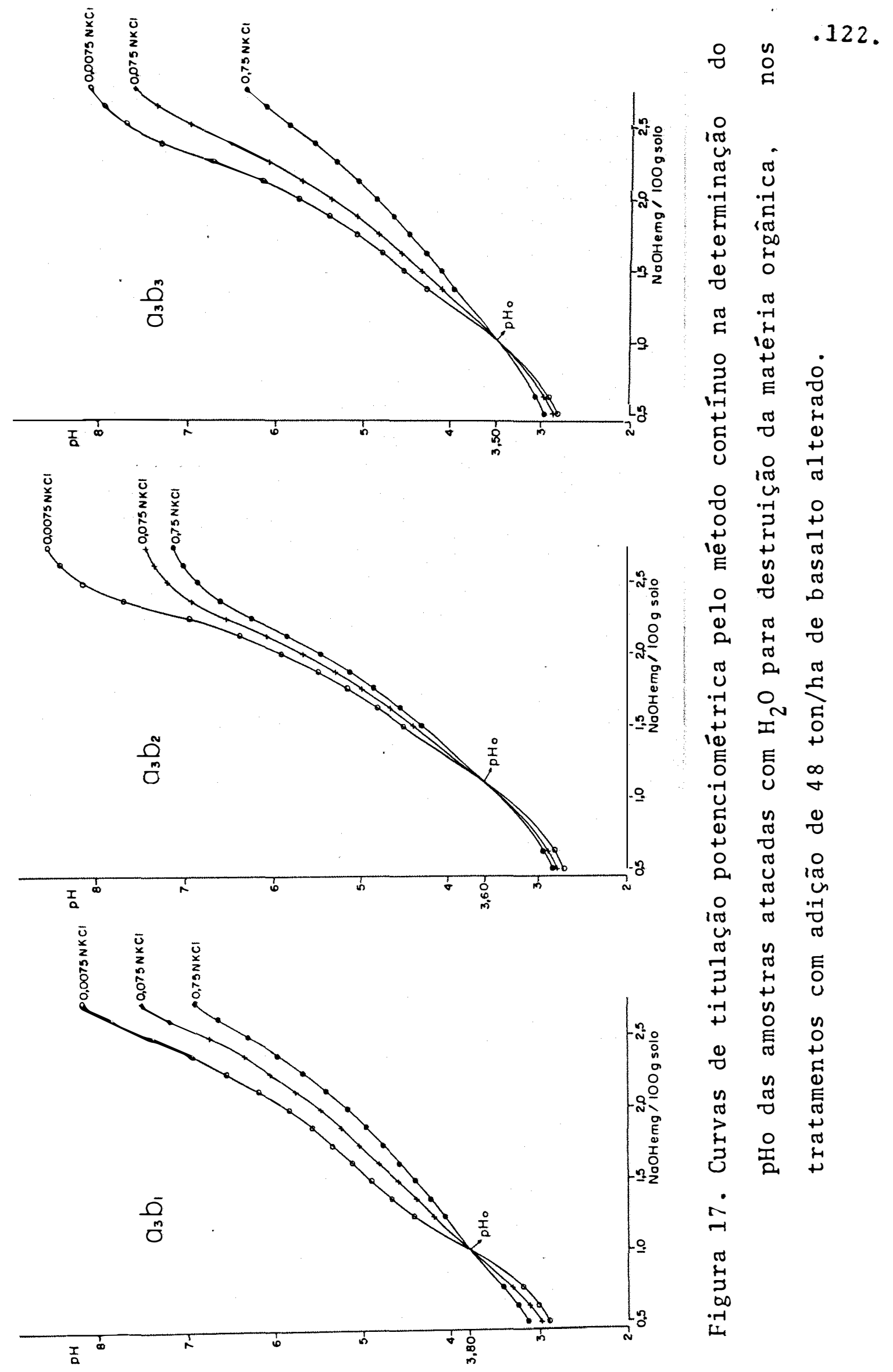




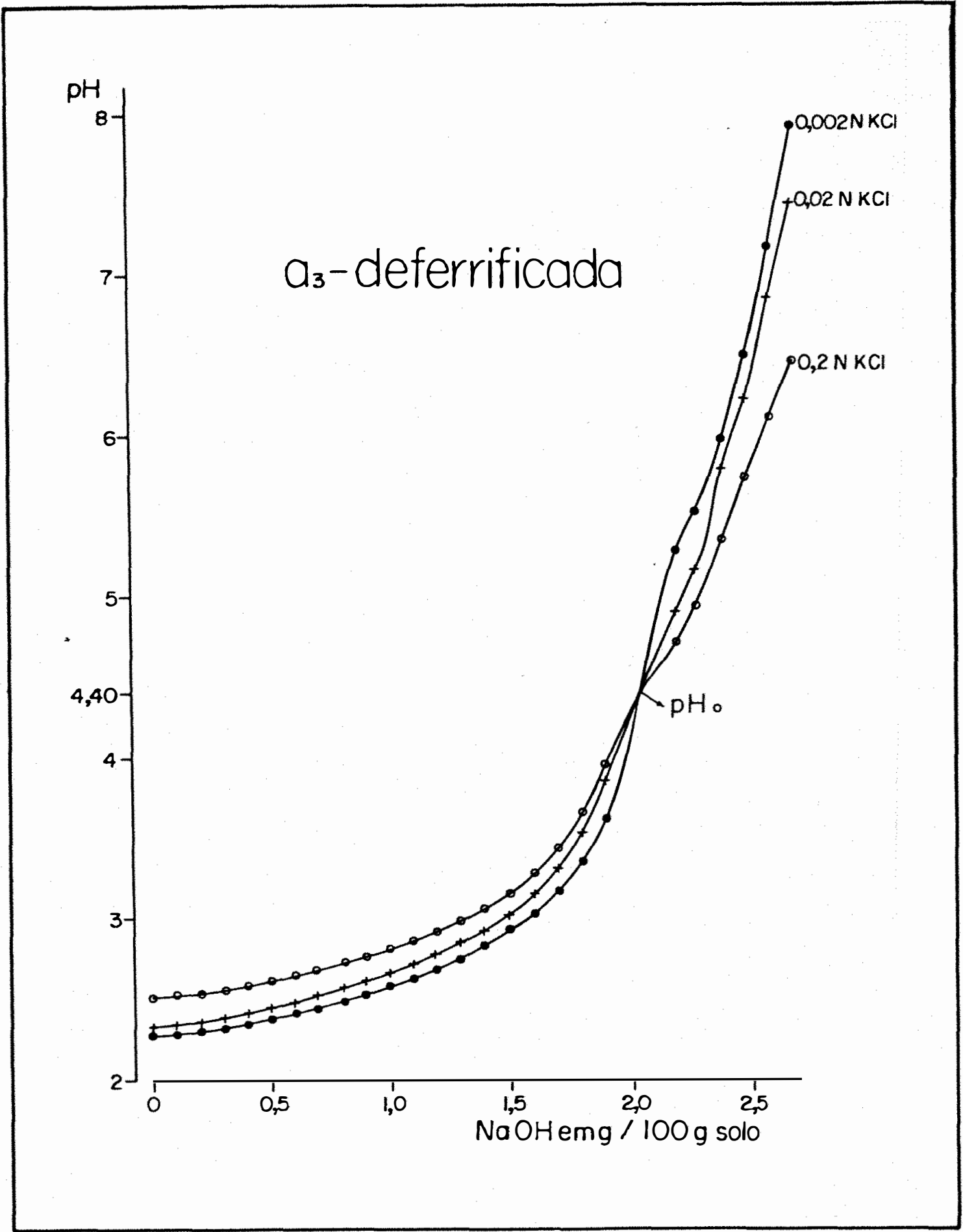

Figura 18. Curvas de titulação potenciométrica pelo método con tínuo na determinação do pHo da amostra $a_{3}$ deferrificada após ataque com $\mathrm{H}_{2} \mathrm{O}$ para destruição da matéria orgânica. 
zero. De acordo com UEHARA e GUILLMAN (1980a) o ZPNC pode ser medido pela adsorção de ions em função do pH. Ao ZPNC alguns cations podem ser adsorvidos às cargas variáveis e, então, o total de cátions adsorvidos pode ser maior ou igual as cargas permanentes medidas a pHo. A equação (15) mostra que ZPNC mo ve-se em direção de pHo com o aumento da concentração de ele trólitos e é menor que pHo se $\sigma_{p}$ for negativa, igual a pHo se $\sigma_{p}=0$, e maior que pHo se $\sigma_{p}$ for positiva. 0 ZPNC pode en tão, ser calculado de duas maneira: pela equação (15), ou pelo método gráfico, através do ponto de cruzamento entre as curvas de adsorção de $\mathrm{K}^{+}$e $\mathrm{Cl}^{-}$em função do $\mathrm{pH}$.

$\mathrm{Na}$ Tabela 7 , os dados da coluna F referem-se ao método da equação e os da coluna 6 ao método gráfico. Podemos constatar que esses dados são mais elevados para o solo natú ral, sem aplicação de basalto, tendendo a decrescer com o au mento da dosagem de basalto aplicada. Para todos os tratamen tos sempre o ZPNC é inferior a pHo, mostrando a existência de cargas permanentes negativas.

Para o basalto alterado, a inexistência do ZPNC pelo método gráfico se deve a grande quantidade de cargas per manentes negativas desse material, em função da sua composição mineralógica de argilas $2: 1$ do grupo da nontronita.

A Figura 19Mc mostra a impossibilidade de inter secção entre as curvas. O valor obtido pelo método da equação $(-8,37)$ também confirma essa impossibilidade por se tratar de um $\mathrm{pH}$ de sinal negativo e de valor absoluto muito alto (Tabela7) 

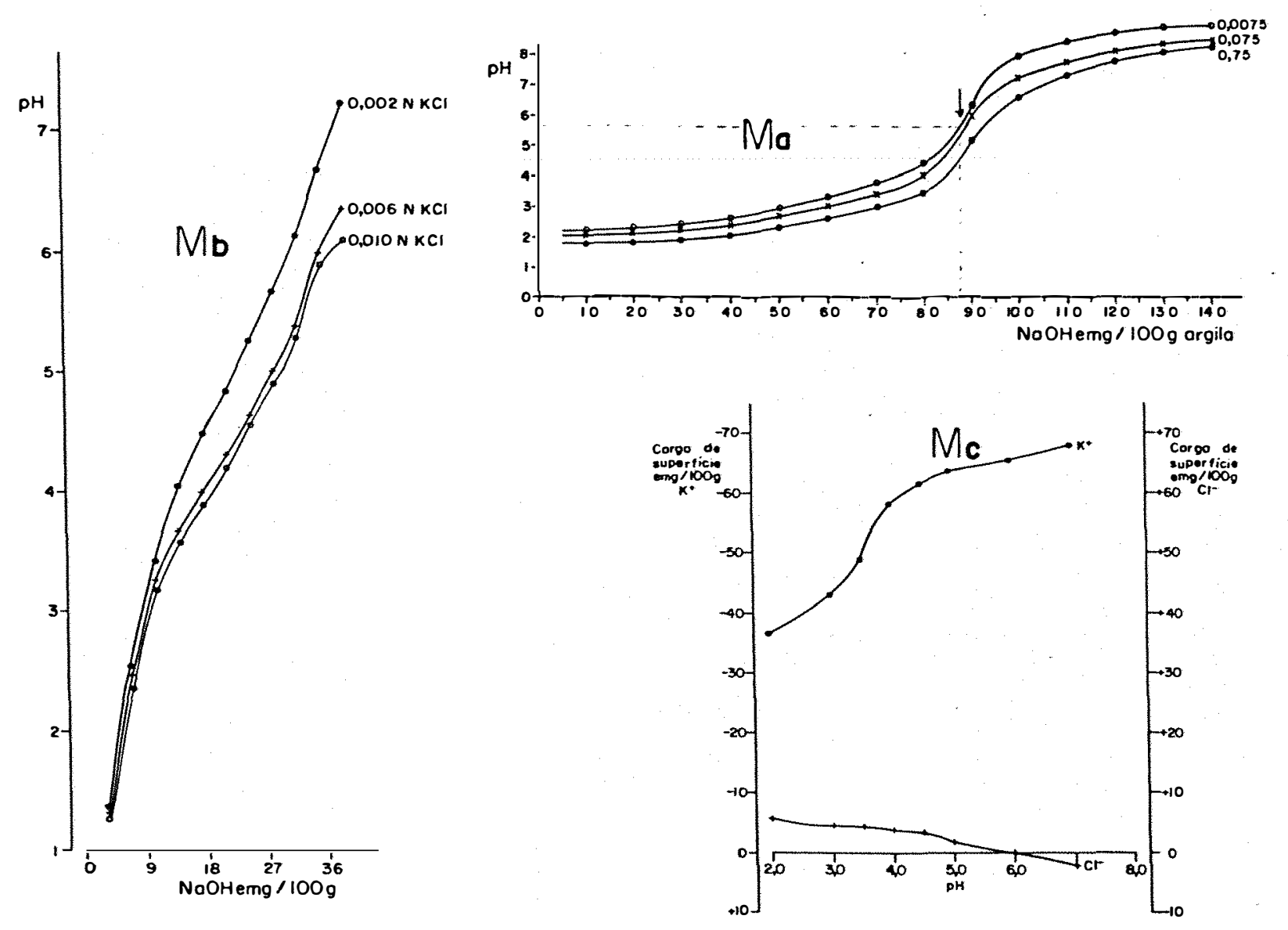

Figura 19. Ma - Curvas de titulação pelo método contínuo na de terminação do pHo do basalto alterado; Mb - Curvas de titulação pelo método da adição para determina ção do pHo do basalto alterado; Mc - Curvas de ad sorção de $\mathrm{K}^{+}$e $\mathrm{Cl}^{-}$em função do $\mathrm{pH}$ para o basalto alterado. 
Pelo método da equação percebe-se uma certa in fluência da adubação no ZPNC que tende a ser mais alto para os níveis de adubação também mais elevados. Essa influência tal vez se deva a alterações nas características das superfícies de cargas pela adsorção de fosfato como supõem MEKARU e UEHARA (1972), SCHALSCHA et alii (1972 e 1974) e GALINDO e BINGHAN (1977), uma vez que os outros elementos como o cálcio, potás sio, magnésio e amônio, são eliminados pelas lavagens preconizadas no método.

A distância entre o ZPNC e o pHo é de certa for ma proporcional a quantidade de cargas permanentes, mas melhor ainda, dá uma indicação da energia de adsorção do ion utiliza do,às cargas de superfície dos colóides do solo, pois para um mesmo valor de $\sigma_{p}$ a inclinação da curva será tanto menor quanto mais distante ZPNC de pHo.

As Figuras 20,21,22 e 23 mostram as curvas de adsorção de $\mathrm{K}^{+}$e $\mathrm{Cl}^{-}$indicando as variações das cargas de superfície em função do pH. Por esses gráficos podemos observar que a partir de pHo,continua a haver um pequeno decréscimo no teor de $\mathrm{K}^{+}$ adsorvido com o abaixamento do $\mathrm{pH}$ até o ZPNC, contrariando em parte a teoria de UEHARA e GILLMAN (1980a)que afirmam ocorrer ainda ao ZPNC alguns cátions às cargas variáveis e por isso o total de cátions adsorvidos podem ser maior que ao valor de pHo. Essa adsorção de cátions às cargas variāveis, podem existirr, mas é muito difícil de precisar a sua ocorrência, uma vez que, com a abaixamento do $\mathrm{pH}$ e consequente aumento da concen- 


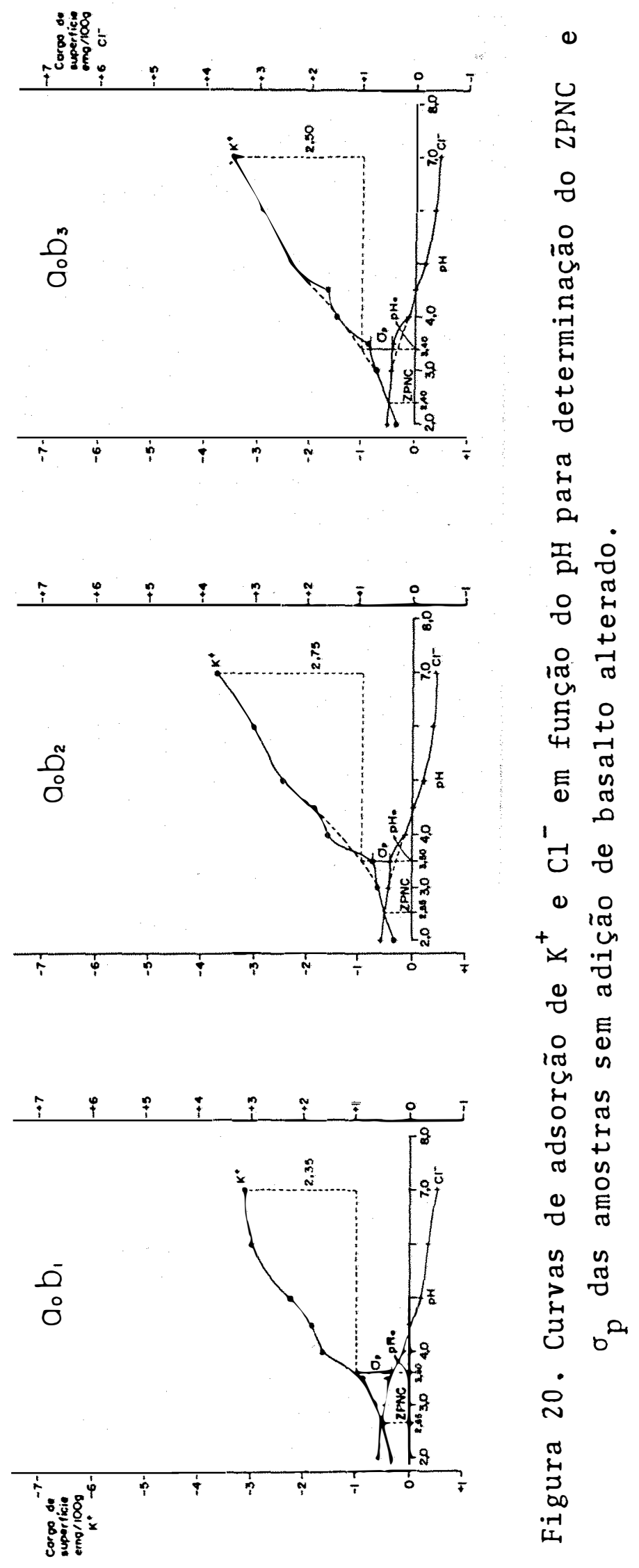




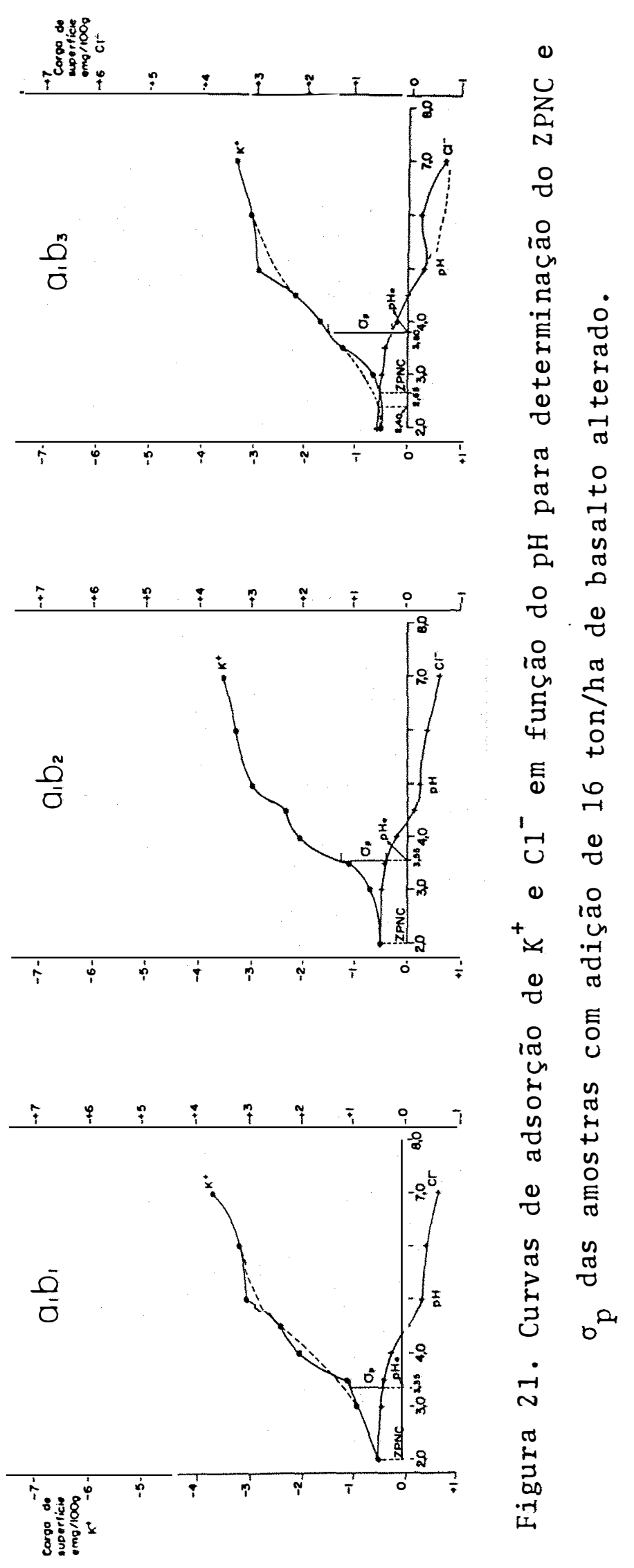




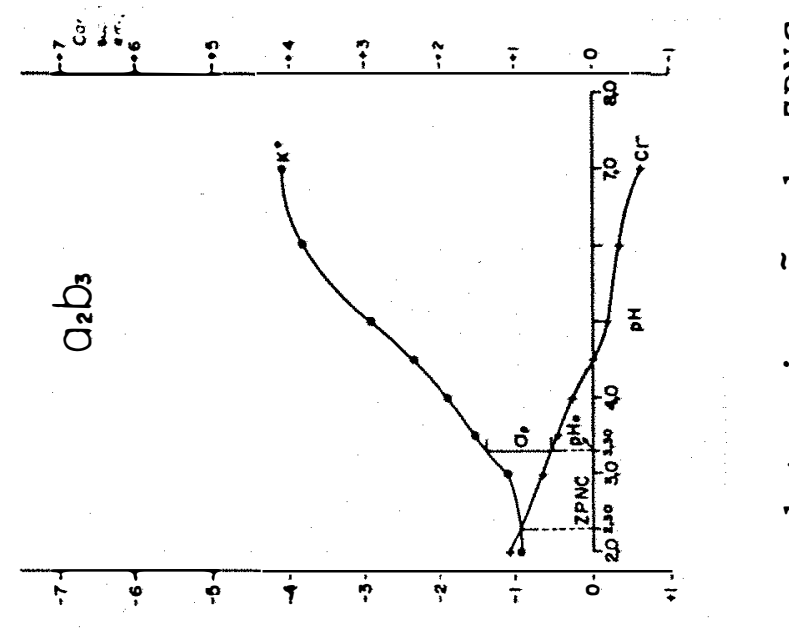

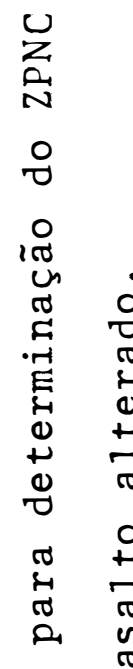

م

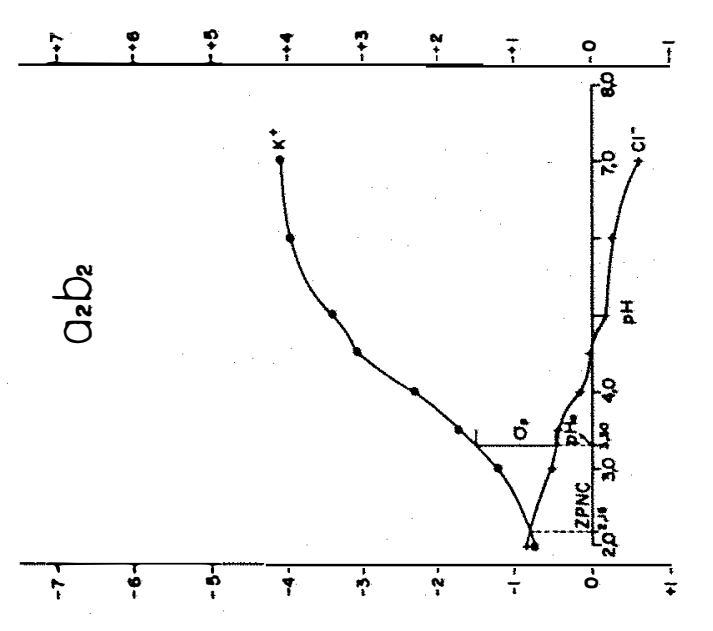

임

10

品

E $N$

1. 0

บ

0

+

๑

이

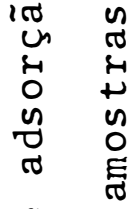

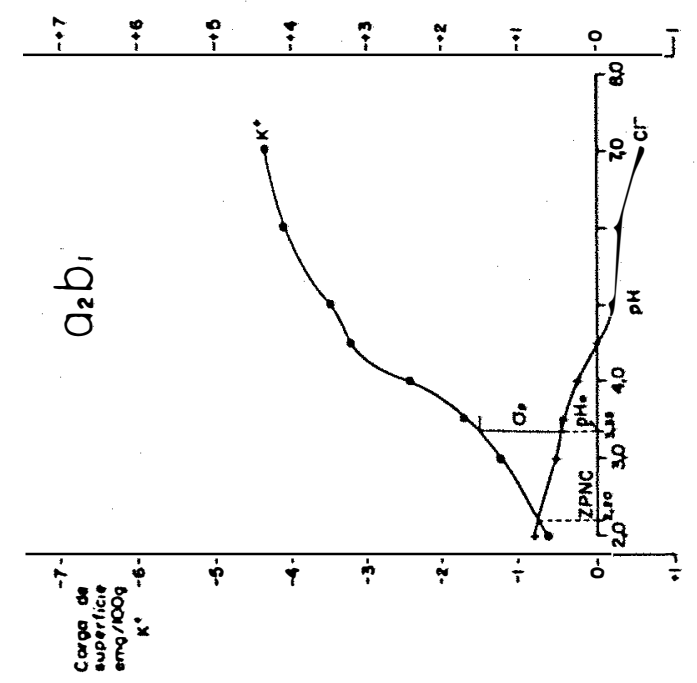

ช

$\overbrace{3}^{\pi} 0^{\infty}$

$\stackrel{\sim}{\sim}$

$\sim$

0
5
5
0
-1
-1 


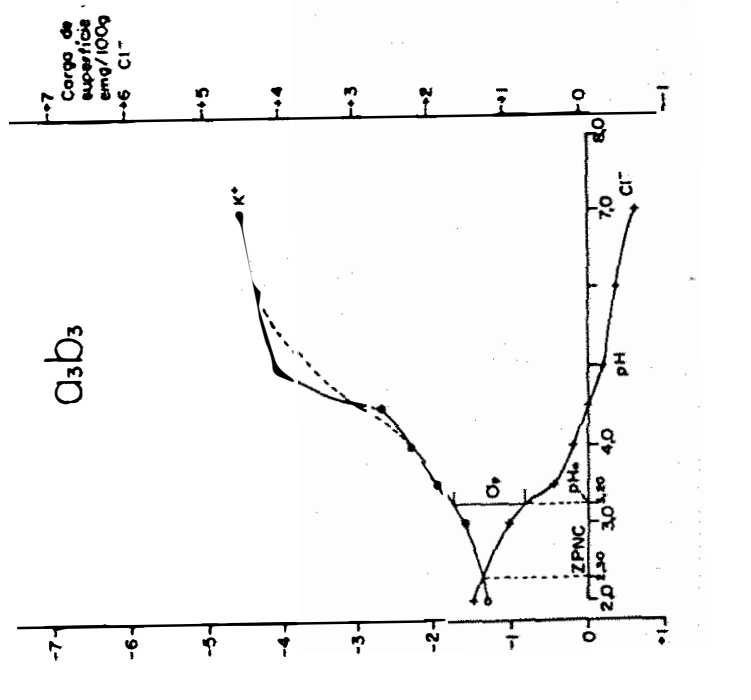

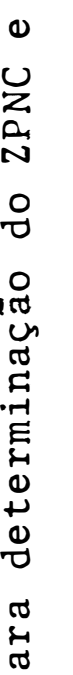

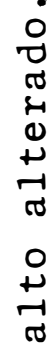

I.

i
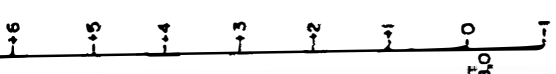

움

๑

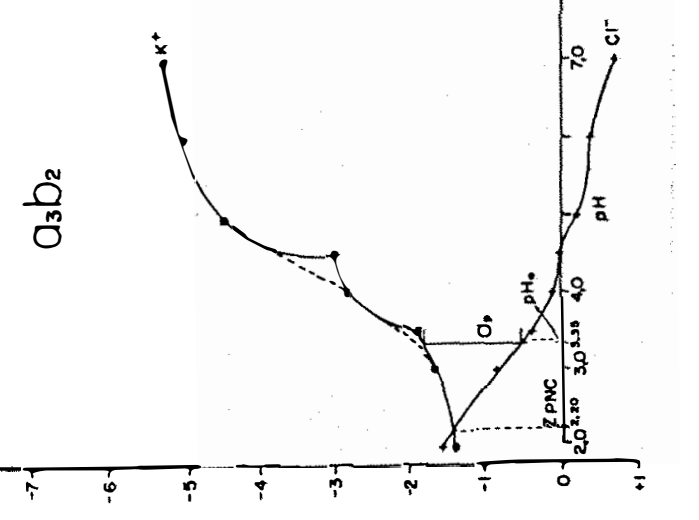

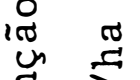

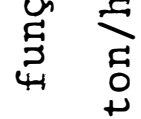

E

' 10

- 0

ty

ग
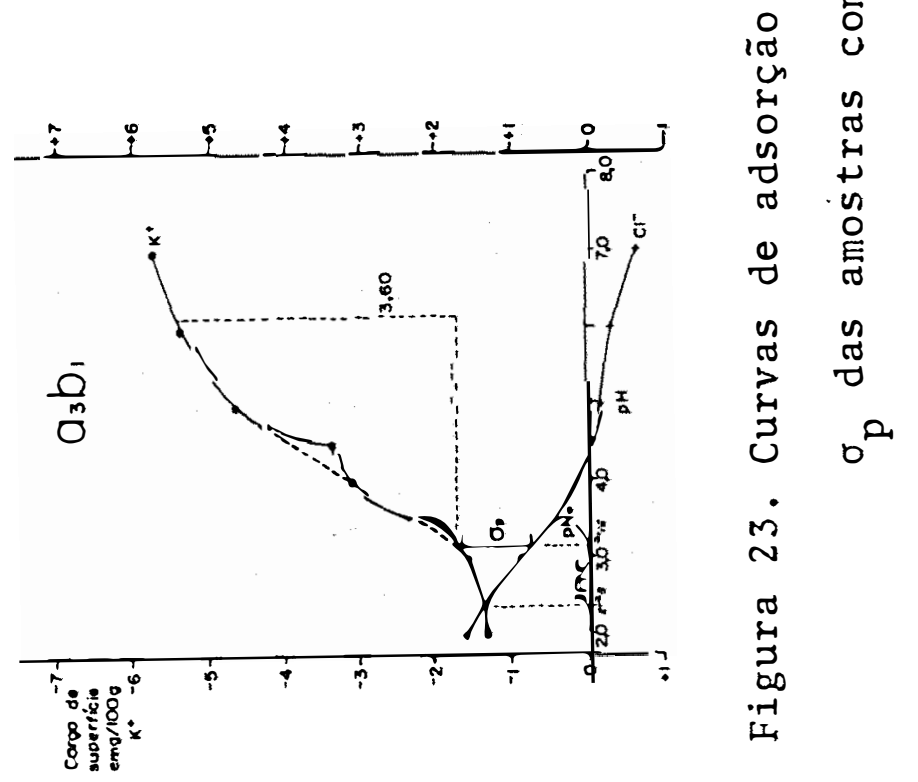
tração de ions $\mathrm{H}^{+}$na solução, ocorrerā um novo equilíbrio en tre os ions $\mathrm{K}^{+}$adsorvidos à fase sólida e a solução, mascaran do aquele fenômeno.

Essa diminuição no teor de $\mathrm{K}^{+}$adsorvido com a diminuição do pH provoca uma elevação nos valores de ZPNC, co mo pode ser constatado pelas discrepâncias entre os dados de ZPNC calculados pela equação(15)expressos na coluna $F$ da Tabe la 7 e os obtidos pelo método da equivalência entre $\mathrm{K}^{+}$e $\mathrm{Cl}^{-}$ adsorvidos, contidos na coluna G da mesma tabela. Essas dife renças são melhores percebidas nas amostras com valores de $\sigma_{p}$. mais elevados.

4.4.4. Superfície específica e cargas de superfície.

As reações dos solos em relação aos elementos nutrientes para as plantas, são em maior parte reações entre as superfícies dos sólidos coloidais e a solução do solo.

A fração mineral coloidal criada pelos proces sos de formação dos solos, possuem superfícies ativas classif cadas por HERBILLON et alii (1977) em duas categorias: (i) su perfícies de óxidos e hidróxidos de Fe e Al que exibem forte afinidade por sílica solúvel, e (ii) superfícies de minerais silicatados que fornecem sílica à solução do solo num processo de intemperismo.

Qualitativamente, BOLT (1960) e JENSEN

distinguem dois tipos de cargas no solo, um denominado de cou lombiana que sempre estão presentes no solo e outro denominado 
de não coulombiana ou específicas que podem ou não existirem no solo. Para Van OLFEN (1963) e UEHARA e GUILLMAN (1980a) os colóides do solo são classificados como: (i) colóides com car ga elétrica constante, sendo o caso das argilas silicatadas on de as cargas provém de substituição isomorfas no interior das unidades cristalográficas e que se manifestam na superfície do colóides, sendo independentes do meio, (ii) colóides de cargas variaveis que possuem características de cargas provenientes da adsorção de ions $\mathrm{H}^{+}$e $\mathrm{OH}^{-}$às suas superfícies e que thes determinam o potencial. Os sesquióxidos, a matéria orgânica e em parte a caolinita são colóides com cargas dependentes de $\mathrm{pH}$.

Quantitativamente, NAFADY (1972) observou a re lação Q/I depende da CTC e da extensão de superfície de troca. Nenhuma dessas definições e conceituações sobre as superfícies coloidais dos solos, parece representar os fenô menos de reações dessas interfacies de modo a resolver em defí nitivo o problema, pois muitos são os fatores que entram em jô go, e suas interaçōes dão sempre reações muito variadas, cons tituindo-se em um vasto campo de pesquisa. Numa tentativa de procurar contribuir com a questão, permitimo-nos, também, dar uma conceituação, procurando abranger as anteriores. Assim, do ponto de vista constitucional os colóides do solo são sistematizados como: (i) colóides cristalinos abrangendo as argilas silicatadas de rede $2: 1$ com tres regiões distintas sendo a superfície interna, causada por substituição isomorfas, com 
cargas permanentes; uma superfície externa com parte de cargas permanentes e parte pH-dependentes; e outra região planar com cargas pH-dependentes; outros colóides cristalinos são as a $\underline{r}$ gilas 1:1, também silicatadas, com pequena parte de cargas per manentes e grande parte de cargas pH-dependentes. Dentro desse mesmo grupo de colóides estão ainda os argilo-minerais não silicatados representados pelos óxidos de ferro cristalinos goe thita e hematita e a gibbsita, todos com cargas pH-dependentes. (ii) colóides amorfos minerais (representados por alofana, hi dróxidos de ferro e alumínio) e a matéria orgānica, todos com cargas dependentes de $\mathrm{pH}$.

Do ponto de vista quantitativo e qualitativo de vemos considerar a densidade de carga, que depende da carga to tal pela extensão da superfície, e ainda as reações de interações entre os vārios tipos de colóides, constituindo colóides de carāter misto ou de apenas um deles bloqueando os sítios de troca do outro.

Entretanto, por mais abrangente que se queira ser, sempre ficam muitos aspectos a serem considerados como por exemplo: se as cargas permanentes são específicas ou não, qual o grau de dependência da concentração iônica do meio e, assim a questão nunca fica fechada em definitivo.

A medida da superfície específica do solo é um parâmetro importante, para a interpretação das suas reações. Dentre os vārios métodos usados na avaliação da superfície es pecifica, na presente pesquisa procuramos comparar o método da 
adsorção do vapor de etileno glicol d $=1,109$ e $\mathrm{n}=1,4314$ deacordo com as recomendações de BRADLEY (1945), GUYOT (1969). Os dados encontram-se na Tabela 10 juntamente com aqueles calculados pe la equação de UEHARA e GUILLMAN (1980b) para adsorção negativa. Constatamos uma boa correspondência entre os métodos, porém com valores um pouco inferiores para o método da adsorção do etileno glicol para o basalto alterado. Provavelmente essa dis crepância ocorra devido ao baixo grau de dispersão das argilas no método do etileno glicol, semelhantemente às proposições de Van BLADEL e LAUDELOUT (1967) para o fenômeno da histerese de troca iônica.

Como consequência da alta superfície específí ca do basalto alterado, as dosagens crescentes desse material aplicado ao solo provocou aumentos na superfície específica do solo em aproximadamento $30 \mathrm{~m}^{2} / \mathrm{g}$ para as maiores dosagens em ambos os métodos, entretanto pela quantidade de basalto altera do aplicado, apenas $15 \mathrm{~m}^{2} / \mathrm{g}$ de aumento seriam esperados, sendo a diferença devida portanto, ao aumento na superfície da matéria orgânica.

\subsubsection{Densidade de carga, cargas permanentes e cargas variáveis.}

Segundo NAFADY (1972) a densidade de carga in flui diretamente nas relações de atividades das leis de rela ções de Schofield que dependem também das quantidades relati vas dos ions envolvidos tanto quanto da superfície de troca, 
Tabela 10. Resultados da superfície específica, densidade de carga e valores de $K^{+}$ads, $\gamma_{a}^{-}$, $\gamma$ e $\gamma_{c}^{-}$para os trata mentos e para o basalto alterado.

\begin{tabular}{|c|c|c|c|c|c|c|c|c|c|c|c|}
\hline \multirow{2}{*}{ Tratamentos } & \multirow[b]{2}{*}{${ }^{(1)} \mathrm{K}^{+}$} & \multirow[b]{2}{*}{$\cdot(2)_{Y_{a}}$} & \multirow[b]{2}{*}{$\left.{ }^{(3)}\right)_{\gamma}(4$} & \multicolumn{4}{|c|}{ Superfícje especifica } & \multirow[b]{2}{*}{$\dot{r}_{\mathrm{c}}$} & \multicolumn{3}{|c|}{ Densidade de carga } \\
\hline & & & & $J_{\text {medida }}(5)$ & calculada & ${ }^{(6)} S_{v}$ & ${ }^{(7)} S_{p}$ & & ${ }^{(8)} \sigma_{v}$ & $\sigma_{T}$ & $o_{\mathrm{p}}$ \\
\hline & & meq/100 & 3 & & $\mathrm{~m}^{2} / \mathrm{g}$ & & 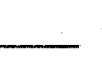 & meq/100g & $10^{3} \mathrm{esu} / \mathrm{cm}^{2}$ & meq/100g & $10^{8} \mathrm{esu} / \mathrm{cm}^{2}$ \\
\hline$a_{0} b_{1}$ & 3,15 & $-0,52$ & 3,68 & 83,9 & 102,5 & 73,2 & 29,3 & 0,40 & $-4,51$ & $-3,08$ & $-5,84$ \\
\hline$a_{0} b_{2}$ & 3,73 & $-0,55$ & 4,28 & n.d. & 106,6 & 80,5 & 26,1 & 0,44 & $-5,22$ & $-3,09$ & $-6,66$ \\
\hline$a_{0} b_{3}$ & 3,47 & $-0,57$ & 4,04 & 81,7 & 112,9 & 78,7 & 34,2 & 0,43 & $-4,80$ & $-3,14$ & $-4,99$ \\
\hline$a_{1} b_{1}$ & 3,52 & $-0,59$ & 4,11 & 87,0 & 117,5 & 82,4 & 35,2 & 0,45 & $-5,56$ & $-3,13$ & $-6,18$ \\
\hline$a_{1} b_{2}$ & 3,53 & $-0,59$ & 4,12 & 94,6 & 117,4 & 84,2 & 33,2 & 0,46 & $-5,42$ & $-3,27$ & $-9,79$ \\
\hline$a_{1} b_{3}$ & 3,38 & $-0,62$ & 4,00 & 96,6 & 126,3 & 95,2 & 31,1 & 0,52 & $-5,39$ & $-3,16$ & $-13,36$ \\
\hline$a_{2} b_{1}$ & 4,33 & $-0,65$ & 4,98 & 101,9 & 126.4 & 89,6 & 36,7 & 0,49 & $-5,84$ & $-3,91$ & $-10,33$ \\
\hline$a_{2} b_{2}$ & 4,18 & $-0,66$ & 4,84 & 102,6 & 129,7 & 87,4 & 42,3 & 0,48 & $-5,92$ & $-3,65$ & $-9,87$ \\
\hline$a_{2} b_{3}$ & 4,16 & $-0,67$ & 4,83 & 102,6 & 132,2 & 84,2 & 48,0 & 0,46 & $-5,66$ & $-3,63$ & $-9,36$ \\
\hline$a_{3} b_{1}$ & 5,67 & $-0,72$ & 6,39 & 108,6 & 135,9 & 86,0 & 49,9 & 0,47 & $-5,96$ & $-4,44$ & $-8,63$ \\
\hline$a_{3} b_{2}$ & 5,25 & $-0,73$ & 5,98 & 115,0 & 139,9 & 95,2 & 44.7 & 0,52 & $-6,02$ & $-4,29$ & $-11,61$ \\
\hline$a_{3} b_{3}$ & 4,52 & $-0,71$ & 5,23 & 110,2 & 139,4 & 87,8 & 51,6 & 0,49 & $-6,23$ & $-3,71$ & $-10,51$ \\
\hline$M$ & 68,59 & $-3,25$ & 71,84 & $618,5^{(9}$ & ${ }^{\prime}(559,8)$ & n.c. & n.c. & n.c. & n.c. & $-77,30$ & ${ }^{(10)}-(74,88)$ \\
\hline
\end{tabular}

(1) $\mathrm{K}^{+}(\mathrm{ads})$ - potássio adsorvido a $\mathrm{pH} 7,0$. (2) $\mathrm{Y}_{\mathrm{a}}^{-}\left(\mathrm{Cl}_{\mathrm{rep}}^{-}\right)$adsorção negativa de $\mathrm{Cl}^{-}$. (3) $\gamma\left(\mathrm{K}^{+}-\gamma_{\mathrm{a}}^{-}\right) \mathrm{caI}$ ga total, potássio adsorvido mais $\mathrm{Cl}_{\text {repl }}^{-}$(4) Superfície específica medida pela adsorção do etileno glicol. (5) calculada pela equaçāo $\gamma^{-}=6,1 \times 10^{-9} \mathrm{~S}-\frac{3,774}{\gamma} \times 10^{-17} \mathrm{~s}^{2}$. (6) Superfície de carga variā vel $S_{v}=-1,83 \gamma_{c}^{-} \cdot 10^{2}$. (7) $S_{p}$ - superfície de carga permanente. (8) $\sigma_{\tau}, \sigma_{v}$ e $\sigma_{p}$ cargas do solo; 0 sinal negativo significa que a carga líquida é negativa. (9) ( ) valor entre parentesis considerada adsorçáo negativa a pH 7,0 uma vez que não há pHo. (10) densidade de carga total $\sigma_{t}=\left(o_{v}+\sigma_{p}\right)$ em $10^{9}$ esu/ $\mathrm{cm}^{2}$ uma vez que não é possível determinar-se as superfícies $S_{v}$ e $S_{p}$ pelo método utilizado. 
mas independe da concentração da solução do solo e nem do teor de umidade do mesmo. Entretanto, CARTER et alii (1979) afirmam que a variação de umidade do solo alteram significativamente as relações iônicas da solução do solo.

Os dados da Tabela 10 mostram um aumento da densidade de carga total do solo, representado pela somatória dos aumentos parciais tanto das cargas permanentes quanto das car gas variáveis. E bastante claro e visível, pelos dados, que o au mento na densidade de carga é acompanhado por um aumento na ca pacidade de troca iônica do solo. Entretanto os valores obtidos para $\sigma_{\mathrm{T}}$ em meq/100g de solo são ligeiramente inferiores a queles para CTC medida tanto pela adsorção de $\mathrm{K}^{+}$como para 0 método do acetato de cálcio.

Comparando-se os dados das densidades de cargas variāveis e permanentes, entre o solo e o basalto alterado, ve rificamos que o aumento na CTC não é perfeitamente proporcio nal ao incremento na densidade de carga. Os valores mais altos da CTC para densidades de cargas mais elevadas, de forma não proporcional, é paradoxal do ponto de vista da maior proximida de entre as cargas que tenderiam a gerar uma certa repulsão entre os ions de mesma carga, mas encontra guarida na teoria Stern da dupla camada difusa, onde a maior densidade de carga permite a formação de uma camada mais espessa.

Com relação as espécies iônicas, os maiores va lores da CTC e $\triangle \mathrm{pH}$ obtidos com o cảlcio é explicado pela sua carga mais elevada e menor raio iônico, mais compatível com 
densidades de carga mais altas. Entretanto, devemos sempre considerar que a desuniformidade das superfícies permitem sem pre a ocorrência de regiões com sítios de adsorção mais especí ficos para um ou outro ion, tal como sugerem JENSEN (1973) e BOLT (1960) pelas denominações de cargas coulombianas e não coulombianas, dando sempre relações de troca muito complexas, não obedecendo a uma simples ordem da série liotrópica como haviam propos to GIESEKING e JENNY (1936). MIELNICZUK (1978) tam bem sugere esta desuniformidade de superfícies.

Os elevados valores de densidades de cargas per manentes e variáveis para o basalto alterado atestam a existên cia de montmorilonita (nontronita) de alta carga com possibili dade de fixação de algum potássio por redução do espaçamento basal como afirma MIELNICZUK (1978) e confirmado pelos difrato gramas de raios-X da Figura 4 onde o espaçamento original de $16 \AA$ reduz-se para $12,2 \AA$ por saturação com potássio.

Os valores das cargas variáveis negativas, contidos na Tabela 10 atestam um pequeno efeito da aplicação de ba salto alterado no aumento dessas cargas, passando de 2,6 meq/ $100 \mathrm{~g}$ em média no solo natural para $3,1 \mathrm{meq} / 100 \mathrm{~g}$ com a maior dose aplicada, devendo-se considerar ainda que parte deste au mento deve ter ocorrido por conta da matéria orgânica.

As Figuras 20,21,22 e 23 mostram a mudança das cargas va riāveis negativas e positivas em função do $\mathrm{pH}$.

Esses gráficos revelam também que os maiores au mentos das cargas variāveis negativas são encontradas de um mo do geral, no intervalo entre o $\mathrm{pH} 3,5$ e $\mathrm{pH} 6,5$, sendo limites 
.138 .

um pouco inferiores aos obtidos por MUNNS e FOX (1977) de 4,8 a 7,1 para um oxissol de textura fina. Para as cargas positi vas são observados valores que decrescem rapidamente com $0 \mathrm{pH}$, atingindo o valor zero próximo ao $\mathrm{pH} 4,5$, concordando com ELSWAIFY e SAIEGH (1975), GALLEZ et alii (1976) e MORAIS et alii (1976). A partir deste valor de $\mathrm{pH}$ começa a aparecer o fenômeno da adsorção negativa de anions da teoria de Gouy-Chapman, $\underline{u}$ tilizada por BARBER e ROWELL (1972) para obtenção da superfí cie específica.

Os baixos valores de cargas positivas bem como o seu rápido decréscimo com o aumento de $\mathrm{pH}$, associado aos pe quenos teores de óxidos de ferro livres explicam, em parte, os valores relativamente altos de fósforo solúvel encontrados nes te solo.

A equação proposta por UEHARA e GUILLMAN (1980a) para determinação das cargas variâveis dão valores bastante consistentes com aqueles obtidos à partir dos gräficos de cargas de superfície contidos na Figura 20.

A räpida diminuição das cargas negativas, próxí ma ao pHo e continuando em direção ao ZPNC com o abaixamento do $\mathrm{pH}$ leva a obtenção de valores de cargas inferiores aos valo res reais, uma vez que são medidas apenas pelo teor de potás sio trocável, enquanto que muitos sítios de troca nas cargas permanentes deverão estar satisfeitos por ions $\mathrm{H}^{+}$e $\mathrm{Al}^{3+}$ em pH tão baixo quanto aos valores de pHo e ZPNC para este solo. A intensidade desta interferência não é negligível como quer 
afirmar MUNNS e FOX (1977a), visto que trabalhamos com valores de $\mathrm{pK}$ em torno de 2 , estando muito próximo aos valores de $\mathrm{pH}$. 0 método da diferença entre $\mathrm{K}^{+}$e $\mathrm{Cl}^{-}$adsorvidos recomendado por UEHARA e GUILLMAN (1980b)provocam uma diminui ção nos valores das cargas permanentes e mascaram também o e feito de adsorção de alguns cátions às cargas variáveis ao ZP NC, descrito pelos mesmo autores e que explicariam também a existência de uma pequena quantidade de cargas variáveis positivas ao pHo.

Estas cargas variáveis positivas, entretanto, de vem ser consideradas, teoricamente pela própria construção grạa fica como cargas positivas permanentes, e que aparecem claramente em solos com $\Delta \mathrm{pH}$ positivo uma vez que são obtidas por troca iônica com sal neutro não tamponado, geralmente KCl $1 \mathrm{~N}$.

Os dados da Tabela 10 mostram com muita evidên cia valores bem inferiores obtidos com o método da diferença entre $\circ \mathrm{K}^{+}$e $\mathrm{Cl}^{-}$adsorvidos em relação ao método das diferen ças entre os ions $\mathrm{H}^{+}$deslocados por sal neutro $\left(\mathrm{CaCl}_{2}\right)$, após diālise do solo com HCl diluído e lavagem do excesso de ácido com água destilada até ausência de $\mathrm{Cl}^{-}$(pH próximo ao pHo). Es te método é proposto pelo autor, neste trabalho, e não apresen ta os incovenientes apontados por KAPOOR e GOSWAMI (1978), uma vez que as cargas bloqueadas por sesquióxidos livres apontadas por HSU e RICH(1960) e SCHUWERTMAN e JACKSON (1964), que não podem ser medidas por deslocamento com sal neutro não tamponado e, que não foram removidas por lavagem com ácido, encontram 
se definitivamente bloqueadas deixando de existir como tal. As sim as proposições de MITRA e KAPOOR (1969) para medida de car gas permanentes por deslocamento da acidez com sal neutro não tamponado são válidas, desde que seja efetuada a diálise ácida como proposto neste trabalho para eliminar os efeitos dos polí meros de alumínio das intercamadas de argilas, citados por RICH (1960), SHEN e RICH (1962) e COLEMAN e THOMAS (1964), não extraível com sal neutro.

0 método da equação:

$$
\sigma_{\mathrm{p}}=-\mathrm{n}^{1 / 2} \cdot 1,67 \cdot 10^{-6}(\mathrm{pHo}-\mathrm{ZPNC})
$$

e o que dá valores menors consistentes e, ainda não é aplicável em casos de materiais com altas cargas permanentes e que não possuam pHo e, consequentemente, não há ZPNC, como è o caso do basalto alterado no presente trabalho.

Os valores de $\Delta \mathrm{pH}$ constantes da Tabela 9 apresentam-se todos com sinal negativo indicando a predominância de cargas permanentes negativas, confirmada pelos valores nega tivos de $\sigma_{\mathrm{p}}$. Os valores absolutos de $\Delta \mathrm{pH}$, sendo diferenças en tre logarítmos, dependem das posiçōes dos valores de $\mathrm{pH}_{\left(\mathrm{H}_{2} \mathrm{O}\right)}$ e ${ }^{\mathrm{pH}}$ (eletrólito), não tendo o significado de distância atribuído por Van RAIJ e PEECH (1972).

4.4.6. Capacidade de troca catiônica (CTC).

Dentre as características de grande expressão zos solos, a capacidade de troca cationica ocupa um lugar de destaque. Dela depende a maior parte das reações físico-quími cas do solo e, consequentemente, a sua fertilidade. Ela é uma 
função da extensão da superfície específica e da densidade de carga dessa superfície.

A sua determinação, normalmente feita através da soma de cations é uma medida de pouco significado, pois na da diz a respeito do potencial do solo em função da variação do pH, que segundo MUNNS e FOX (1977), a elevação do pH de 4,8 para 7,1 pode aumentar a CTC em até quase tres vezes. Ademais, este método pode conter um erro devido aos cations da solução do solo que são somados aos cations trocáveis, principalmente se a amostragem é feita logo após uma adubação.

Os dados da Tabela 5 relativos à CTC mostram as variações desse parâmetro para diversas situações e condições. A coluna $A_{1}$ apresenta valores de CTC pelo método do acetato de cálcio a pH 7,0 superiores ao mesmo método à $\mathrm{pH}$ 5,0 em aproximadamente $40 \%$, porém com valores sempre consistentes e crescen tes com o aumento de basalto alterado aplicado ao solo. Para o método do azul de metileno, todavia, os valores além de serem mais baixos não apresentam um aumento crescente compatível com os métodos anteriores. Estas discrepâncias são perfeitamente explicáveis pelas considerações de SCHOFIELD (1949) sobre as variações das cargas elétricas em função do $\mathrm{pH}$, bem como as afirmações de Van RAIJ e PEECH (1972) que acrescentam também o efeito da valência e da concentração do ion considerado. Com relação ao azul de metileno, os baixos valores obtidos, se de vem à histerese de troca apontada por MAES e CRAMMERS (1975) e Van BLADEL e LAUDELOUT (1967), que no caso do referido ion, é 
.142 .

favorecida pelas suas dimensões de $17 \times 7,6 \times 3,3 \AA$ (HANG e BRINDLEY, 1970) podendo medir'apenas as superfícies externas das argilas 2:1 que apresentam um espaçamento basal de 12,2 a $16,0 \AA$ como mostra a Figura 4. Se considerarmos que realmente, apenas a superfície externa foi medida pelo azul de metile no teriamos um valor de $249,9 \mathrm{~m}^{2} / \mathrm{g}$ de superfície externa para $618,5 \mathrm{~m}^{2} / \mathrm{g}$ de superfície total para o basalto alterado. Toda via, esse valor para a superfície externa é um tanto incerto uma vez que as densidades de carga não são iguais para as refé ridas superfícies.

Em solos tropicais com a fração argila constitu ída de caolinita e óxidos e hidróxidos de ferro e alumínio (ABRUNA et alịi, 1964; ESPINDOLA e GALHEGO, 1975) a matéria or gânica entra com importante contribuição na CTC (ROLE DE LA MA TIERE ORGANIQUE DANS LA FERTILITE DU SOL, s.a., 1975). Na Tabe la 5 os dados da coluna $B_{1}$ referem-se as amostras tratadas com $\mathrm{H}_{2} \mathrm{O}_{2}$ para eliminação da matéria orgânica e mostram a redução drástica nos valores da CTC, e a coluna C apresenta a diferença entre as amostras naturais e aquelas tratadas com $\mathrm{H}_{2} \mathrm{O}_{2}$, re velando valores em torno de $1,9 \mathrm{meq} / 100 \mathrm{~g}$ para a matéria orgâni ca representando aproximadamente $45 \%$ da CTC do solo natural. A coluna $\mathrm{A}_{2}$ contém os teores de matéria orgânica das amostras pa ra os anos de 1978 e 1979 e mostram uma pequena variação no pe ríodo, sendo que na coluna $B_{2}$ aparecem os dados das amostras tratadas com $\mathrm{H}_{2} \mathrm{O}_{2}$ que indicam uma boa eficiência de oxidação da matéria orgânica pelo método empregado. 
$\mathrm{Na}$ mesma Tabela aparecem, ainda, os valores da CTC calculada pela soma de cátions para os anos de 1978 e 1979. Não houve praticamente, variação da CTC para o solo natural,pe 1o cultivo no período, contrariamente aos resultados de SINBAD (1972); CABANETTES e LE BUANNEC (1974). Para os tratamentos com adição crescente de basalto alterado há uma nítida tendência de aumento da CTC de 1978 para 1979 .

Através dos dados das colunas $\mathrm{C}, \mathrm{A}_{2}$ e $\mathrm{B}_{2}$ da Tabela 5 e os dados da análise granulométrica relacionados na Tabela 1, podemos chegar aos valores da CTC para as frações orgânica e mineral, apresentados na Tabela 5. A matéria orgâni ca apresenta valores muito variáveis para a CTC e sem qualquer influência das dosagens de adubação ou do basalto alterado, en quanto que a fração mineral apresenta dados crescentes de CTC com o aumento de basalto alterado aplicado ao solo. Os valores inconsistentes para a CTC da matéria orgânica mostram claramen te a natureza heterogênea dos estágios de humificação em que se encontra este componente no solo, indicando que os teores de matéria orgânica ou carbono total determinados pelo método empregado é de pouco significado para fertilidade do solo, tal como revela a baixa correlação entre matéria orgânica e potássio trocável na Figura 25. E provável que melhores resultados seriam obtidos se a determinação da matéria orgânica fosse efe tuada nas frações mais finas, como silte e argila. 

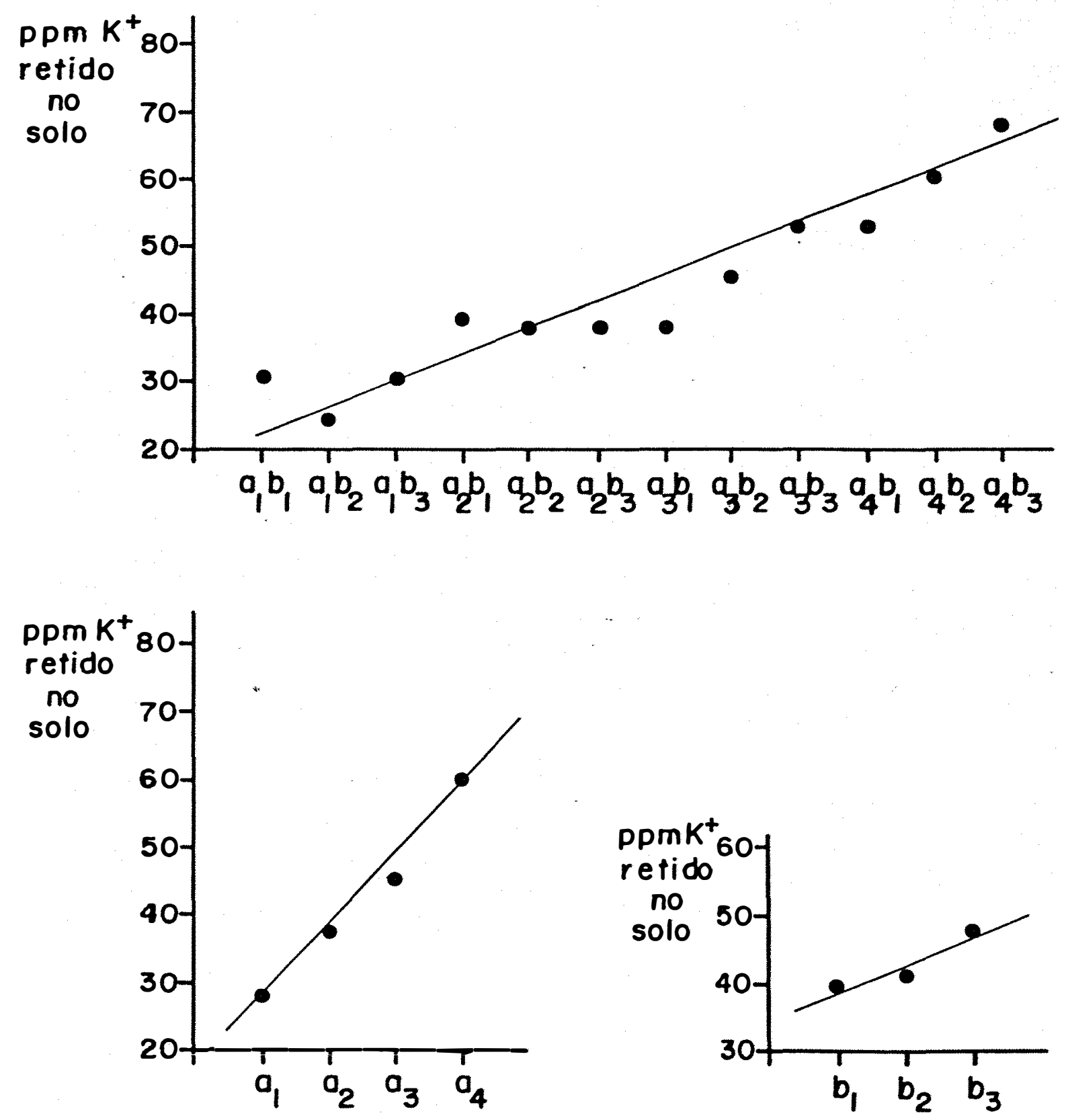

Figura 24. Efeitos dos níveis de basalto alterado $\left(a_{0}, a_{1}\right.$, $a_{2}$ e $\left.a_{3}\right)$ e doses de adubação $\left(b_{1}, b_{2} e b_{3}\right)$ na $\underline{\text { re }}$ tenção de $\mathrm{K}^{+}$por percolação de solução $0,01 \mathrm{~N} \mathrm{KCl}$. 
4.4.7. Relações iônicas, relações de atividades e coe ficiente de seletividade.

0 equilíbrio iônico no solo é devido em grande parte pelas espécies mineralógicas presentes no solo e diferem grademente de comportamento frente aos diversos ions do solo. Segundo MCLEAN (1971) as argilas 2:1, com cargas permanentes, apresentam maior afinidade por ions bivalentes enquanto as car gas pH-dependentes das argilas $1: 1$, óxidos e hidróxidos de fer ro-alumínio e matéria orgânica preferem os ions monovalentes. Para REEWIGH eVILLIERS (1968) os óxidos de ferro determinam predominantemente cargas pH-dependentes, podendo ser de caráter anfotérico. KINNINURGH et alii (1975) estudando as proprieda des dos óxidos de ferro e aluminio concluiu que hã uma adsorção preferencial desses geis por cálcio em relação ao sódio. Muitos resultados obtidos com solos tropicais com cargas variáveis predominantes, apresentam-se, por vezes, de modo aparentemente contraditório. Em alguns casos (LEITE et alii, 1970); TELLA et alii, 1970; VERDADE et alii, 1966) o po tāssio aparece fortemente lixiviado por cālcio, em outros ( GUE et alii, 1970, MASCARENHAS et alii, 1970; MIYASAKA et alii, 1966) o cálcio e o magnésio são relativamente menos retido que o potássio.

As relações iônicas apresentadas na Tabela 11 mostram um aumento na relação $\mathrm{Ca}^{2+} /$ cations totais de modo cres cente com o aumento da quantidade de basalto alterado adiciona do aos solos. 0 indice de 0,12 no solo natural, índice esse 
.146.

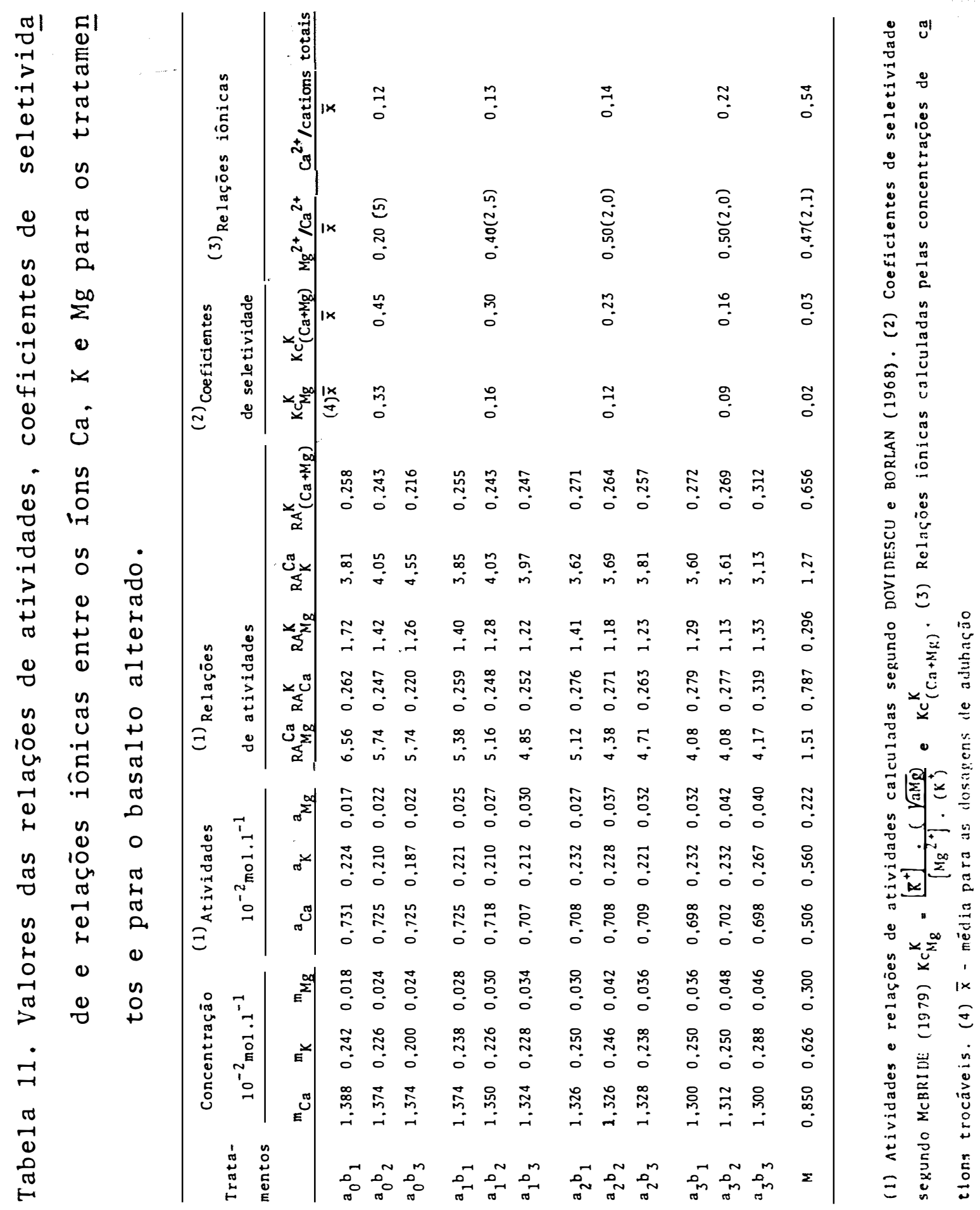


que segundo CARTER et alii (1979) está abaixo do limite mínimo para ocorrência de condições adversas para o crescimento de a gumas plantas. Com a aplicação de basalto alterado a elevação desse índice atinge $o$ valor de 0,22 para a maior dose aplicada sendo que para o basalto o valor é de 0,54 .

Para a relação $\mathrm{Mg}^{2+} / \mathrm{Ca}^{2+}$, o solo natural apre senta um valor de 0,20 , também muito próximo ao limite mínimo citado pelo referido autor. Este índice aumenta rapidamente já com a primeira dosagem de basalto alterado, mantendo-se mais ou menos constante com as demais dosagens com valor semelhante ao do próprio basalto alterado.

Esses dados revelam os efeitos benéficos da $\underline{a}$ plicação do basalto alterado para o cálcio e mostram uma maior quantidade relativa de magnésio trocável através do aumento das dosagens aplicadas.

A Tabela 11 mostra também as relações de atividä des $\mathrm{RA}_{\mathrm{Mg}}^{\mathrm{Ca}}$ que diminuem gradativamente com o aumento das dosagens de basalto alterado, concordando no mesmo sentido com as relações iônicas para esses ions, porém com valores um pouco mais altos para as relações de atividades. Os valores várias vezes mais altos para as relações de atividades entre cálcio e magnésio para o solo em comparação com o basalto alterado, in dica a menor afinidade desse material para o magnśeio em relação ao cálcio, concordando com MUNNS (1976) e BAWEJA e MCLEAN (1975) de que as cargas pH-dependentes de argilas silicatadas adsorvem fracamente o cálcio. Contrariamente as cargas pH-de 
.148 .

pendentes nos oxissolos, principalmente aquelas relativas ao humus, retem fortemente os ions cálcio, tal como relata MUNNS (1976 e 1977), dando relações de atividades mais altas para $\mathrm{Ca}^{2+} / \mathrm{Mg}^{2+}$ encontradas no presente trabalho.

A participação da matéria orgânica na CTC desse solo, avaliada em torno de $45 \%$ é bastante coerente com esses dados das relações de atividades entre cálcio e magnésio com maior afinidade pelo primeiro. As cargas devidas à fração mine ral e principalmente ao fosfato adsorvido não se relacionam ao cálcio, como se poderia supor, pois GALINDO e BINGHAM

verificaram que o incremento na densidade de carga através da ad sorção de fosfato não resultou em nenhum efeito na seletividade entre cālcio e magnésio.

As relações de atividades entre potássio e cál cio é muito próxima aquelas entre potássio e cálcio mais magné sio de modo que nesse caso os dois ions podem ser tratados como um único ion como afirmam SCHOFIELD e TAYLOR (1955) e BE CKETT (1964 e 1965). Os valores dessas relações tendem a um pe queno aumento com a adição crescente de basalto alterado ao so 10, devido a relação também não mui to alta nesse material,mostrando sua baixa afinidade por potássio sendo deslocado mais facilmente por cálcio, estando em conformidade com ELGABALY e WIKLANDER (1949), BROW e NOGGLE (1965), MCLEAN e MARSHALL (1948) para argilas silicatadas $2: 1$.

Esses resultados, aparentemente, estão em des $\underline{\text { a }}$ cordo com MIELNICZUK (1978) que afirma haver seletividade por 
potássio para montmorilonitas de alta carga. Entretanto deve mos considerar que a adsorção específica por potássio não a brange todos os sítios de carga dessasargilas e que por outro lado a adsorção específica quando ocorre, imobiliza os sítios de troca correspondentes, passando a partícula a funcionar co mo um trocador não específico para reações em pequenos interva los de tempo.

Pelas relações de atividades entre cálcio e mag nésio constatamos uma maior afinidade do basalto alterado por magnésio, com valores para esse índice bem inferiores ao do so 10, o que, consequentemente, acarreta valores para as relações de atividades entre potássio e magnésio bem mais acentuadas que para o cálcio. Assim os valores de $\mathrm{RA}_{\mathrm{Mg}}^{\mathrm{K}}$ decrescem marcada mente com a adição crescente de basalto alterado, bem como po demos observar os valores bem mais baixos para $R_{M g}^{K}$ do que $\mathrm{RA}_{\mathrm{Ca}}^{\mathrm{K}}$ para o basalto alterado.

Os coeficientes de seletividade são índices que dão informações mais precisas sobre as atividades das superfí cies ou dos sítios de troca pelos diversos ions estudados. Os dados contidos na Tabela 11 mostram valores para os coeficien tes de seletividade entre potássio e magnésio muito coerentes com as relações de atividades, decrescendo com o aumento da do sagem de basalto alterado aplicado ao solo e sendo bem inferior no basalto alterado.

$$
\text { Para } \left.\mathrm{Kc}_{(\mathrm{C}}^{\mathrm{K}} \mathrm{C}+\mathrm{Mg}\right) \text { os valores são sempre superiores }
$$
a $\mathrm{Kc}_{\mathrm{Mg}}^{\mathrm{K}}$ nos tratamentos correspondentes, também concordantes com as relaçōes de atividades entre os referidos ions, decres 
cendo a medida que aumenta a dosagem de basalto alterado e con sequentemente com a densidade de carga como se refere BERGSETH (1980) •

A análise geral dos resultados obtidos para as relações de atividades e coeficientes de seletividade permite asseverar, claramente, que a matéria orgânica possui maior af $\underline{i}$ nidade pelo cálcio; a montmorilonita (nontronita do basalto a terado) adsorve preferencialmente o magnésio e, portanto, a maior seletividade por potássio, apresentada pelo solo natural é devida à caolinita, uma vez que é o mineral predominante nes te solo.

4.4.8. Titulação potenciométrica.

A titulação de argilas e solos tem sido objeto de estudo de muitos autores como COLEMAN et alii (1964); COLE MAN e THOMAS (1964); DE VILLIERS e JACKSON (1967), DEWAN e RICH (1979). A titulação potenciométrica contínua permite a de terminação quantitativa dos ions hidrogênio e alumínio, sendo que em presença de eletrólito é possível distinguir-se o alumínio, trocável daquele não trocável (SCHWERTMANN e JACKSON, 1963; VIOLANTE e VIOLANTE, 1973).

A titulação potenciométrica do basalto alterado (Figura 19Mb) mostra que não são muito distinguíveis entre si os dois primeiros tampões referentes aos ions $\mathrm{H}^{+}$e $\mathrm{Al}\left(\mathrm{H}_{2} \mathrm{O}\right) \frac{6}{6}^{3+}$ referidos por VIOLANTE e VIOLANTE (1977), porém, é observado um único tampão bem nítido até próximo ao pH 5,0. E muito pro- 
vável que esta não distinção entre os dois primeiros tampões seja devida a predominância de ions $\mathrm{H}^{+}$em relação ao $\mathrm{Al}^{3+}$ nes te material, como mostram os dados da Tabela 6. A partir do $\mathrm{pH}$ 5,0 até $\mathrm{opH}$ 5,5 ocorre nitidamente os pontos de inflexão das curvas e, em seguida, aparece claramente o terceiro tampão até o pH 8,2 devido aos polímeros de alumínio citados por SCHWERTMANN e JACKSON (1963 e 1964), ou a um complexo aluminio-silicato a que se referm SAWHNEY e FRINK (1966), ou ainda a hidroxilas de arestas quebradas como propõem JACKSON (1960) e MAY (1973).

0 solo, bem como os tratamentos, não apresentam muito evidente o terceiro tampão como no basalto alterado, con cordando perfeitamente com VIOLANTE e VIOLANTE (1973 e 1977) com que o contínuo aumento desse terceiro tampão é devido ao envelhecimento dos polímeros de alumínio, embora o ion $\mathrm{Al}^{3+}$ não predomine entre os ions trocáveis no caso presente, mas é o segundo ion em teor vindo após $0^{+} \mathrm{H}^{+}$(Tabela 11).Para SAWHNEY (1968) e HSU (1968) é possível que pelo envelhecimento, esses complexos se tornem muito fixados não sendo neutralizados pela titulação mesmo que $\circ \mathrm{pH}$ da solução externa se eleve até 8,0 . Estes resultados podem, contudo, se deverem a problemas relati vos à metodologia da titulação contínua ser executada muito ra pidamente não havendo tempo suficiente para as reações se com pletarem, pois como afirmam BERUBE et alii (1967) e BLOK e BRUYN (1970) entre os fatores que afetam essas reações está o tempo de contacto. A Figura 19Mb permite observar que a quantidade de $\mathrm{NaOH}$ necessária à titulação até o ponto de inflexão das cur 
vas é de aproximadamente $87 \mathrm{emq} / 100 \mathrm{~g}$, valor este, muito próxí mo à CTC do material que é de $80,04 \mathrm{emq} / 100 \mathrm{~g}$. Este resultado dá uma indicação de que a acidez titulada até o ponto considera do é correspondente aos ions $\mathrm{H}^{+}$e $\mathrm{Al}^{3+}$ trocáveis como afirmam VIOLANTE e VIOLANTE (1977), podendo talvez, ser uma forma de determinação da CTC para esse tipo de material. Para o solo (Figuras 6 a 9 ), os pontos de inflexação das curvas não são ví síveis, entretanto, a titulação até $\circ \mathrm{pH}$ próximo a 8,0 , fornece valores de $\mathrm{NaOH}$ mais próximos aos teores de cargas varia á veis, provavelmente por serem as cargas predominantes nesse so 10 .

4.4.9. Correlações entre $\mathrm{K}^{+}$retido por percolação e ou tros componentes do solo.

Com o objetivo de verificar-se o comportamento do potássio no solo foi passada uma solução de KCl 0,01N atra vés das amostras dos diversos tratamentos em percoladores de vidro. No extrato recolhido foi determinado o teor de $K^{+}$e, a través da diferença de concentração para a solução padrão calculou-se as quantidades de $\mathrm{K}^{+}$retido pelo solo.

As Figura 25aeb mostram correlações entre 0 po tássio retido o teor de $\mathrm{Mg}$ e o teor de cálcio existente no solo $(R=0,90$ e $R=0,80$ respectivamente). Fica evidente, por tanto, que em concentrações mais elevadas o potássio promove deslocamento do cálcio e magnésio por efeito de ação de massa mesmo contra uma força seletiva para estes ions mostrando que 

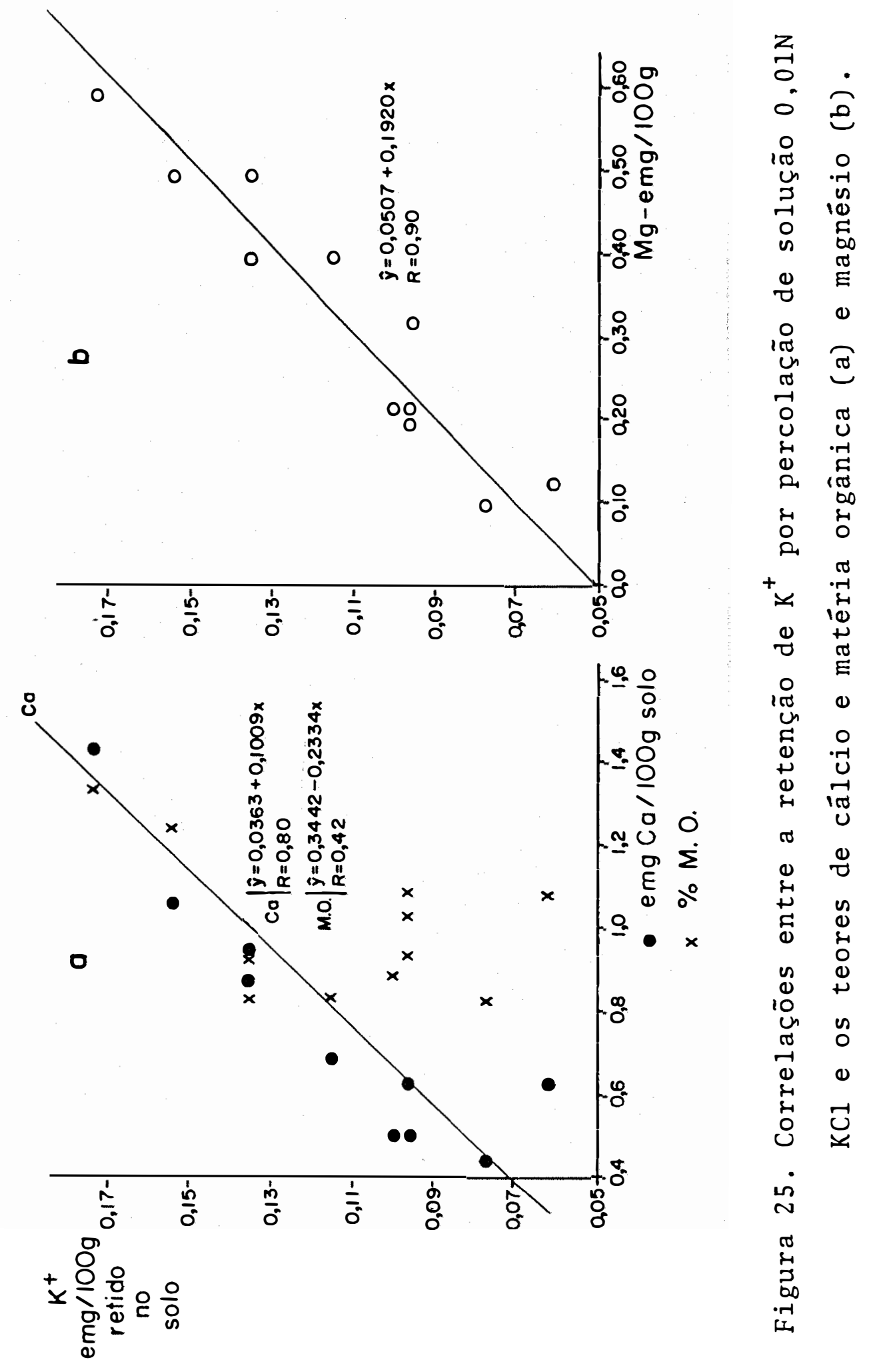

i

萂

$\approx 0$

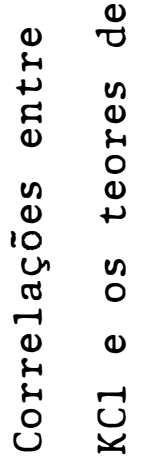

$\stackrel{\sim}{\sim}$

$\pi$
5
0
0.1
.1 
a seletividade da superfície é restrita à determinadas regiões ou sítios de troca, ou então ela diminui à medida que aumenta a concentração do ion referência.

A matéria orgânica, entretanto, não apresenta correlação com o teor de potássio retido, indicando a sua bai xa afinidade para adsorção desse ion. A Figura 25a mostra o va lor de $R \neq 0,42$ para este par de eventos.

0 teor de potássio retido no solo apresenta ma ior correlação positiva entre as doses de basalto que para a dubação. Para a adição de basalto alterado, concluímos que a correlação positiva deve-se ao efeito de ação de massa e, tam bém, pelo aumento da CTC, enquanto que para a adubação o fenômeno deve estar mais relacionado à insolubilização do $\mathrm{Al}^{3+}$ por $\mathrm{PO}_{4}^{3-}$ das superfícies de troca da caolinita liberando sítios mais específicos para $\mathrm{K}^{+}$, uma vez que, de acordo com a simples adsorção de fosfatos nas superfícies dos colóides, diminue a seletividade por $\mathrm{K}^{+}$ao mesmo tempo que ela se torna ma ior para o ion cálcio.

\subsubsection{Considerações gerais.}

As pesquisas em físico-química de solos visam, na maioria das vezes, dar esclarecimentos sobre as reações dos solos considerando-o como um meio fornecedor de água e nutrien tes às plantas. Muitos dos resultados ou explicações, quando considerados de forma isolada, são aparentemente contraditó rios entre os diversos pesquisadores. Entretanto, algumas pon 
derações se fazem necessárias para o esclarecimento dessas dis crepāncias.

Em primeiro lugar a utilização de termos muito genéricos como solos tropicais, solos brasileiros, solos ferra líticos ou mesmo solos altamente intemperizados não constituem uma boa caracterização do material que foi objeto de estudo.E sas denominações carecem de informações básicas a respeito da composição mineralógica (MCLEAN, 1971; WIJK e WILLIERS, 1968; RIFFALDI e LOTTI, 1978), da textura (ALLISON, 1973) e da estrú tura do solo (WILLIANS et alii, 1967; GABRIELS et alii, 1973; SEFANSON, 1973; CHOPART e NICOV, 1976) .

As diferenças entre as condições de trabalho le vam fatalmente à interpretações diversas e não comparáveis. Com relação ao equilíbrio iônico no solo LEITE et alii (1970); TELlA et alii (1970); VERDADE et alii (1976), mostraram que o cálcio tem um efeito significativo no desloca mento do potássio, enquanto que IGUE et alii (1970); MASCARE NHAS et alii (1970); MIYASAKA et alii (1966) verificaram que o cálcio e o magnésio são retidos com energias relativamente menores que o potássio para solos altamente intemperizados. Por outro lado, NAFADY (1972) demonstrou que solos empobreci dos fixam mais potássio e o cedem em menor quantidade, da me $\underline{s}$ ma forma que NYE et alii (1961); BECKET e NAFADY (1969) afirmam que as leis das relações são mais vâlidas para medir a dis ponibilidade de um nutriente quando este encontra-se em deficiência ou próximo a ela. 
Vemos então que o potássio será mais ou menos deslocado por cálcio dependendo do seu nível de saturação no solo.

Em estudos de troca iônica os coeficientes indi viduais de atividade para cátions adsorvidos, são frequentemen te calculados com base em uma simples isoterma de adsorção, que nem sempre é determinada a uma mesma força iônica, não se ob tendo resultados comparáveis. Os coeficientes de seletividade, entretanto, são semelhantes em quaisquer concentrações de solü ções, variando apenas com a composição mineralógica, permitindo a comparação de resultados, tal como afirmam JENSEN (1973a) e NAFADY (1972).

As discrepâncias de resultados de devem, em geral, a uma falta de padronização de condições de trabalho, ou então, à utilização de índices não muito adequados ao fenômeno a ser medido. 
5. CONCLUSØES

Dentre os diversos resultados obtidos, aqueles mais consistentes no alcance dos objetivos propostos, e que permitiram obter certas conclusões, destacam-se com relevância: a) a ocorrência de haloisitas e/ou "fire-clays"; os teo res em torno de $70 \%$ de argilas na rocha basáltica alterada,cons tituídas principalmente por nontronitas, de elevada capacidade de troca de cátions $(80 \mathrm{meq} / 100 \mathrm{~g})$; a presença dos elementos me nores $\mathrm{Mn}, \mathrm{Ti}, \mathrm{Zn}$ e $\mathrm{Cu}$ e elementos traços $\mathrm{V}, \mathrm{Zr}, \mathrm{Cr}$, Os e $\mathrm{Rh}$; o contato do magma com sedimentos porosos do arenito élico.Tais resultados tornam evidentes a existência de um processo de al teração metassomático hidrotermal, sobre basaltos da formação Serra Geral.

A aplicação de 48 ton/ha desse material promo veu aumentos esperados de 3,92 para até $7,69 \mathrm{meq} / 100 \mathrm{~g}$, nos va lores da CTC do solo estudado.

Para as condições estudadas, as determinações 
das cargas permanentes pelo método baseado em valores de $\Delta \mathrm{pH}$, através da equação:

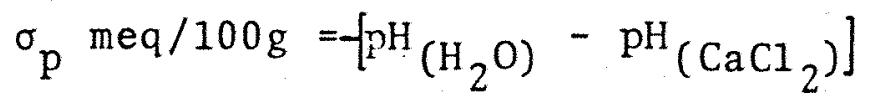

proposta neste trabalho, ofereceu resultados mais coerentes com os valores de CTC do que aqueles obtidos pela diferença en tre adsorção de $\mathrm{K}^{+}$e $\mathrm{Cl}^{-}$a pHo, como também pela equação:

$$
\sigma_{p}=-n^{1 / 2} \cdot 1,67 \cdot 10^{-6}(\mathrm{pHo}-\mathrm{pH})
$$

A aplicação de basalto alterado no solo promo veu alterações em suas propriedades físico-químicas, represen tadas pelas variações de determinados parâmetros, dentre os quais: a) relações de atividades $\mathrm{RA} \mathrm{Mg}_{\mathrm{Ca}}^{\mathrm{a}}$ de 6,56 à 4,08, $\mathrm{RA}_{\mathrm{Ca}}^{\mathrm{K}}$ de 0,220 à $0,319, \mathrm{RA}_{\mathrm{Mg}}^{\mathrm{K}}$ de 1,72 à 1,13 e $\mathrm{RA}_{(\mathrm{Ca}+\mathrm{Mg})}^{\mathrm{K}}$ de 0,258 à 0,312 ; relações iônicas $\mathrm{Mg}^{2+} / \mathrm{Ca}^{2+}$ de 0,20 a $0,50, \mathrm{Ca}^{2+} / \mathrm{ca}$ tions totais de 0,12 à 0,22 ; coeficientes de seletividade $\mathrm{Kc}_{\mathrm{Mg}}^{\mathrm{K}}$ de 0,33 à $0,09, \mathrm{Kc}_{(\mathrm{Ca}+\mathrm{Mg})}^{\mathrm{K}}$ de 0,45 à 0,16 ; elevação dos teores de cálcio e magnésio trocáveis e fósforo solūvel.

As nontronitas presentes no basalto alterado, embora possuindo alta carga de superfície, não apresentam o fenômeno de retrogradação do potássio, como bem explicam os va lores dos coeficeintes de seletividade $\mathrm{Kc}_{\mathrm{Mg}}^{\mathrm{K}}$ e $\mathrm{Kc}_{(\mathrm{Ca}+\mathrm{Mg})}^{\mathrm{K}}$, a demonstrar um fácil deslocamento do potássio adsorvido por cāl cio e magnésio.

Foi possível concluir-se que a matéria orgânica apresenta maior afinidade por cálcio, que as argilas nontroni 
.159 .

tas são mais seletivas para calcio, enquanto que o potássio em baixas concentrações, apresenta uma adsorção preferencial pela caolinita.

A ocorrência de grandes jazidas de basaltos a terados por processos metassomáticos hidrotermais, com recristalização de argilas de alta capacidade de troca catiônica per mite estabelecer que esse material pode ser utilizado como um melhorador de solo. 
.160 .

6. LITERATURA CITADA

ABRUNA, F. ; J.V. CHANDLER e R.W. PERSON, 1964. Effects of liming on yields and composition of heavely fertilized grasses and soil properties under humid tropical conditions. Soil Sci. Soc. Proc., 28: 657-661.

ACQUAYE, D.K. ; A.J. MACLEAN e H.M. RICE, 1967. Potential and capacity of potassium in some representative soils of Ghana. Soil Sci., 109: 79-89.

ADDISCOTT, T.M., 1970. The potassium Q/I relationship of soils given different K manuring. J. Soil Sci., 18(2):244-262.

ALEXIADES, C.A. e M.L. JACKSON, 1965. Quantitative determina tion of vermiculite in soils. Soil Sci. Soc. Am. Proc. 29: $522-527$.

ALLEN, V.T. 1948. Formation of bauxite from basaltic rocks of Oregon. Economic Geology, 43: 619-62.

ALLEN, V.T. e V.E. SCHEID, 1946. Nontronite in the Columbia River Region. Am. Mineralogist, 31: 294-312. 
ALLISON, D. 1973. Soil organic matter and its role in crop pro duction. Els. Sci. Publ. Cons., Amsterdam.

ALMEIDA, F.F.M. de, 1956. O planalto basáltico da Bacia do Paraná. Bol. Paulista Geog., São Paulo, 24: 3-34.

ALMEIDA, F.F.M. de, 1964. Grupo São Bento. In: Geologia do Es tado de São Paulo, p. 85-101. Inst. Geogr. Geol., São Pau 10. Boletim n: 41. $262 \mathrm{p}$.

ARRIVETES, J. 1974. Fertilization des variétés locales de sor gho sur les sols ferrugineux tropicaux du plateau Mossi (Haute-Volta). Doc. IRAT. Haute-Volta. 34 p.

AYRES, A.S. 1961. Liming Hawaiian sugar-cane soils soils. Ha waii Plant Rec., 48: 83-92.

BAKER, C.L. 1923. The lava field of the Parana Basin, South America. Jour. Geol., 31: 66-79.

BARBER, R.G. e D.L. ROWELL, 1972. Charge distribution and the cation exchange capacity of an iron-rich kaolinitic soil. J. Soil Sci., 23: 135-146.

BARBOSA, 0. 1934. Petrografia sedimentária e estratigráfica do Triângulo Mineiro, Minas Gerais. Anais da Escola de Minas de Ouro Preto, 25: 35-39.

BARBOSA, 0. 1936. Notícias sobre estudos geológicos-Econômicos em Patos, MG. Miner. e Metal., $1(5,6): 165$.

BAWEJA, A.S. e E.0. MEcLEAN, 1975. Bonding of $\mathrm{Ca}$ and $\mathrm{K}$ by ve miculite and kaolinite clays as affected by H-clay addition. Soil Sci. Soc. Am. Proc., 39: 48-50.

BECKETT, P.H.T. 1964 a. Studies on soil potassium. I. Confirma 
tion of the ratio law: Mesurement of potassium potential. J. Soil Sci., 15: 1-8.

BECKETT, P.H.T. 1964b. Studies on soil potassium. II. The imme diate Q/I relations of labile potassium in the soil. J. Soil Sci., 15: 9-23.

BECKETT, P.H.T. 1964c. K - Ca exchange equilibrio in Soils. Specific adsortion sites for K. Soil Sci, 97: 376-381. BECKETT, P.H.T. e M.H.M. NAFADY, 1967. Studies on soil potassium. VI. The effect of K-fixation and release on the form of the $\mathrm{K}:(\mathrm{Ca}+\mathrm{Mg})$ exchange isotherm. J. Soil Sci., 18: $244-262$.

BERG, W.A. e G.W. THOMAS, 1959. Anion elution patterns from soils and clays. Soil Sci. Soc. Proc., 23:348-350. BERGSETH, H. 1980. Selektivitut von illit, vermiculit und sme ctit gengenuber $\mathrm{Cu}^{2+}, \mathrm{Pb}^{2+}, \mathrm{Zn}^{2+}, \mathrm{Cd}^{2+}$ und $\mathrm{Mn}^{2+}$. Acta Agri culturae Scandinavica,; 30: 460-467.

BERTHIER, P. 1827. Nontronite: Nouveau Minéral. Annales de Chi. mie-Physique. $36: 22-27$.

BERUBE, Y.G. ; G.Y. ONODA JUNIOR e P.L. DE BRUYN, 1967. Proton adsortion at ferric oxide-aqueous solution interface. II. Analysis of kinetic data. Surface Sci., 7: 448-461. BOCKHEIM, J.G. e T.M. BALLARD, 1975. Hydrotermal soils of the Crater of Mt. Baker, Washington. Soil Sci. Soc. Am. Proc., 39: 977-1001.

BOYER, J. 1972. Soil potassium. In: Soils of the humid tropics, pp. 102-135. Compilado por Comittee on tropical Soils, Na 
tional Research Council. National Academy of Sciences, Washington, D.C.

BOLT, G.H. 1955. Ion adsorptions by clays.Soil Sci, 79:267-276. BOLT, G.H. 1960. Cations in relation to clay surfaces. Trans. $7^{\text {th }}$ Int. Congr. Soil Sci., II, p. 321.

BLAKEMORE, L.C. 1973. Potassium status of Western Samoan Soils: a note. N-Z.J. Exp. Agric., 1: 213-216.

BLANCHET, R.J. ; J. GOYOT ; J. CHAUSSIDON ; J. CROUZET e C. CHAUMONT. 1965. Influence prédominante des argiles ,illiti ques sur l'alimentation potassique des plants dans divers types de sols. Ann. Agron., 16: 177-202.

BRADFIELD, E.G. 1969. Quanty/intensity relations in soils and the potassium nutrition of the strawberry plant. (Fragonia sp.). J. Sci. Food Agric., 20: 32-38.

BRADLEY, W.F. 1945. Molecular associations between : montmorillo nite and some polyfunctional organic liquids.

BRADY, N. 1974. The nature and properties of soils. $8^{\mathrm{a}}$. ed. Mc millan Pub1. Co, Inc., N.Y. 639 p.

BRANNER, J.C. 1896. Decomposition of rocks in Brazil. Jour. Geo1., IV: 529-540.

BREEUWSMA, A. e J. LYKLEMA, 1973. Physical and chemical adsortion of ions in eletrical double layer of hematite. J. Colloid Interface Sci., 43: 437-448.

BRENES, E. e R.W. PEARSON, 1973. Root responses of three grani neae species to soil acidity in an oxisol and an Ultisol. Soil Sci., 116: 295-302.

BROWN, D.A. e J.C. NOGGLE, 1955. Ion exchange in soil plant root environments. Soil Sci. Soc. Am. Proc., 19: 131-134. 
BLOK, J. e P.L. DE BRUYN. 1970. The ionic double payer at the Zno/solution interface. II. Composition model of the surface. J. of Colloid Interface Sci., 32: 527-532.

CABANETTES, J.P. e B. BUANEC, 1974. Etude de I'apparition d'u ne carence potassique dans un sol ferralitique sur granite. L'Agron. Trop., $29(6,7): 675-684$.

CARSON, C.D. e J.B. DIXON, 1972. Potassium seletivity in certain montmotillonite soil clays. Soil Sci. Soc. Am. Proc., 36: $838-843$.

CARTER, M.R. ; G.R. WEBSTER e R.R. CAIRNS. 1979. Effect of moisture change and salinity on the $\mathrm{Mg} / \mathrm{Ca}$ ratio and ratio of $\mathrm{Ca} /$ total cations in soil solutions. Can.J.Soil Sci., $\underline{59}$ : $439-443$.

CATANI, R.A. e A.0. JACINTO, 1974. Avaliação da fertilidade do solo. Métodos de Anālise. Ed. Livroceres Ltda., São Paulo, $61 \mathrm{p}$.

CATANI, R.A. ; J.R. GALlO e H. GARGANTINI, 1955. Amostragem de solo, métodos de análise, interpretação e indicações gerais para fins de fertilidade. Campinas, Instituto Agronômico, Bo1. $\mathrm{n}^{\circ} 69,29 \mathrm{p}$.

CHOPART, J.L. e R. NICOU, 1976. Influence du labour sur le de veloppement radiculaire de differentes plants cultivees au Senegal. Consequences sur leur alimentation hydrique. Agro nomie Tropicale, $31(1): 7-28$.

CHRISTENSON, D.R. e E.C. DOLL, 1978. Magnesium uptake from ex 
changeable and nonexchangeable sources in soils as measured by intensive cropping. Soil Sci., 126(3): 166-168.

CHU, C.H. e L.J. JOHNSON, 1979. Cation-exchange behavior of clays and synthetic aluminosilica gels. Clays and Clays $\mathrm{Mi}$. nerals, 27(2): 87-90.

CHU, C.H. ; L.J. JOHSON e G.A. HUSSEY, 1977. Quantitative clay mineral analysis using simultaneus linear equations. II. An example. Agron. Abtr. $69^{\text {th }}$ Annu. Meet. Am. Soc. Agron., Los Angeles, Calif. p. 187 (abstract).

COLEMAN, N.T. e D. CRAIG, 1961. The spontaneous alteration of hydrogen clay. Soil Sci., 91: 14-21.

COLEMAN, N.T. e G.W. THOMAS, 1964. Buffer curves of acid clays as affected by the presence of iron and aluminium. Proc. Soil Sci. Soc. Am. 28: 187-190.

COLEMAN, N.T. ; G.W. THOMAS ; F.H. LE ROUX e G. BREDELL. 1964. Salt exchangeable and titrable acidity in bentonite sesquio xide mixture. Soil Sci. Soc. Am. Proc. 28: 35-37.

COLEMAN, N.T. ; S.B. WEED e R.J. MCCRACKEN, 1959. Cation ex change capacities and exchangeable cations of piedmont soils of North Carolina. Soil Sci. Soc. Am. Proc., 33:689-693.

COMISSÃO INTERESTADUAL DA BACIA PARANÁ-URUGUAI (1964). Aprove $\underline{i}$ tamento integral do Rio Paraná. Usina Hidroelétrica Para nayara. Relatório de 1963.

COLLIER, D. 1961. Mise au point sur les processus de l'altera tion des granites em pays tempérés. Ann. Agron. 12(3): 273331 . 
.166 .

COLLINS, J.H. 1977. Remarks on gramenite from smallcombe and the chloropal group of minerals. Mineralog. Mag. 1 1:67-82. DAVIDESCU, D. e Z. BORLAN, 1968. Interpretations thermodinami ques des factures chimique de la fertilité du sol-Colloque Roumain. Redactia Revistelar Agricole, Bucarest, $\underline{1}: 25-47$.

DAVIDTZ, J.C. e M.E. SUMMER, 1965. Blocked charges on clay mi nerals in sub-tropical soils. J. Soil Sci., 16(2): 270-274. DEER, W.A. ; R.A. HOWIE e J. ZUSSMAN, 1966. An introduction to the rock-forming minerals. John Wiley, New York. 528 p. DEMATTE, J.L.I. 1974. Estudo agrotécnico das terras da Usina Barra Grande de Lencóis Paulista S.A. Vol. I. Levantamento semidetalhado dos solos. Departamento de Solos e Geologia ESALQ/USP, Piracicaba. 232 p. (mimeog.) .

DE MUMBRUM, L.E. e C.D. HOOVER, 1958. Potassium release and fi xation related to illite and vermiculite as single minerals and in mixtures. Soil Sci. Soc. Am. Proc., 22:222-225. DERBY, 0.A. 1896. Decomposition of rocks in Brasil. Jour.Geol. 4: $529-540$.

DE VILLIERS, J.M. e M.L. JACKSON, 1967. Aluminous chlorite or $\underline{i}$ gin of $\mathrm{pH}$-dependent cation exchange capacity variations. Soil Sci. Soc. Am. Proc., 31: 614-619.

DEWAN, H.C. e C.I. RICH, 1970. Tritation of acid soils. Soil Sci. Soc. Am. Proc., 34: 38-44.

DIXIT, S.P. 1979. The potentiometric titration curves and zero point of charge of some colloids. Agrochimica, 23(2) 122-127. DOWDY, R.H. e T.B. HUTCHESON JR. 1963. Effect of exchangeable potassium level and drying upon availability of potassium to plants. Soil Sci. Soc. Am. Proc., 27: 521-523. 
DUCHAUFOUR, P 1970. Précis de pedologie. Masson et Cie Editeurs - Paris. $481 \mathrm{p}$.

EATON, F.M. ; R.B. HARDING e T.J. GANZE. 1960. Soil solution extraction at tenth-bar moisture percentages. Soil Sci., 90: 253-258.

EDMEADES, D.C. e M.J. JUDD, 1980. The effects of lime on the magnesium status and equilibrio in some New Zeland topsoils. Soil Sci., 129(3): 156-161.

EINSELE, G. ; J.M. GIESKES ; J. CURRAY ; D.M. MOORE ; E. AGUAYO; M.P.AUBRY ; D. FONARI ; J. GUERRERO ; M. KASTNER ; K. KELTS; M. LYLE, Y. MATOBA ; A. MOLINA-CRUZ ; J. MIEMITZ ; J. RUEDA ; A. SAUNDERS; H. SCHADER; B. SIMONEIT e V. VACQUIER, 1980. Intrusion of basaltic sills into highly porous sedi ments, and resulting hydrothermal activity. Nature, 283: 441-445.

ELGABALY, M.M. e L. WIKLANDER, 1949. Effect of exchange capaci ty of clay mineral and acidoid content of plant on uptake of sodium and calcium by excised barley and pea roots. Soil Sci. 78: $181-188$.

EL-SWAFY, S.A. e A.H. SAYEGH. 1975. Charge characteristics of an oxisol and inseptisol from Hawaii. Soil Sci., 120 (1): $49-56$.

ESPINDOLA, C.R. 1979. Pedogênese em āreas basālticas de rever so de cuestas no médio curso do Rio Tietê. Botucatu, Facul dade de Ciências Agronômicas/UNESP. 212 p. (Dissertação de Mestrado) . 
ERICKSON, E. 1959. Cation - exchange equilibrio on clay mine rals. Soil Sci., 74: 103-113.

FRANCO, R.B. 1952. Zeolitas dos basaltos do Brasil Meridional, gênese e paragênese. Bol. Fac. Fil. Cien. Let. USP, São Pau 10, $130: 1-14$.

GABRIELS, D.M. ; W.C. MOLDENHAUER e KIRKHAN •1973. Infil tration, hydraulic conductivity and resistance to waterdrop impact of clod beds as affected by chemical treatment. Proc. Soil Sci. Soc. Am., 34: 634 .

GALINDO, G.G. e F.T. BINGHAM, 1977. Homovalent and heterova lent cation exchange equilibrio in soils with variable surface charge. Soil Sci. Soc. Am. J., 41:883-896.

GALHEGO, H.R. 1973. Contribuição ao estudo da gênese de latossolos - fase arenosa no município de Botucatu-SP.

FCMBB Botucatu-SP. 84 p. (Tese de Doutoramento).

GALHEGO, H.R. e C.R. ESPINDOLA, 1979. Mineralogia de solos de senvolvidos de produtos de alteração de rochas eruptivas bāsicas em Botucatu-SP. Rev. Bras. Cien. Solo, 3:131-135. GALHEGO, H.R. ; C.R. ESPINDOLA ; W.A. CARVALHO e D. RAMBAUD, 1979. Mineralogia da fração argila em uma litotopossequên cia de solos no município de Botucatu. Rev. Bras. Ciên. So $10, \underline{3}: 126-130$.

GALLEZ, A. ; A.S.R. JUO e A. HERBILLON, 1976. Surface and char ge characteristics of selected soils in tropics. Soil Sci. Soc. Am. J., 40: 601-607.

GASCHO, G.J. ; H.J. ANDREIS, 1974. Respuesta de la caña de azu car a escoria de silicato cálcico aplicado a suelos organi- 
cos y arenosos. Proc. Int. Soc. Sugar Cane Thecnol., 17: 543-551.

GAUR, A.C. 1969. Studies on the availability of phosphate in soil as influenced by humic acid. Agrochimica, 16(1):62-65. GESSA, C. 1970. Lo scambio Ca-K sui materiali allofanici. Agro chimica, $14: 188-197$.

GESSA, C.P. ; P. MELIS, G. BELLU e C. TESTONI. 1978. Inactiva tions of clay pH-dependent charges in organomineral comple xes. J. Soil Sci., 29(1):58-65.

GHOSH, G. 1977. Release of non-exchangeable cations from soils. J.Ind.Soc. Soil Sci., 25: 155-160.

GIESEKING, J.E. e H. JENNY, 1936. Behavior of polyvalent ca tions in base exchange. Soil Sci., 42(4): 273-280.

GLAESER, R. ; S. BEgUiNOT e J. MERING, 1972. Détection et de nombrement des charges à localization tètraédrique dans les smectites di-octaédriques. C.R. Acad. Sci., 273,2399-2404. GREWAL, J.S. e S.N. SINGH, 1979. Critical levels of available potassium for potato in the aluvial soils of Punjab. Ind.J. Agric. Sci., 49(10): 802-809 .

GUIDICINI; G.L. e J.O. CAMPOS, 1968. Notas sobre a morfogenese dos derrames basálticos: Bol. Soc. Bras. Geol., 17(1):15. GUIMARAES, D. 1933. A província magmática do Brasil Meridional. Serv. Miner. Geol. do Brasil, Rio de Janeiro, Boletim $\mathrm{n}$ \% $64.70 \mathrm{p}$.

GUIMARAES, D. 1955. Contribuição ao estudo dos tufos vulcani cos da Mata da Corda, MG. Bol. Inst. Tec. Ind., Belo Hor $\underline{i}$ zonte, $18: 1-32$ 
GUIMARAES, D. 1964. Geologia do Brasil. Departamento Nacional da Produção Mineral, Rio de Janeiro, Memória, $\underline{1}: 448$.

GUTMANS, M. 1943. Rochas-mater da Terra roxa. Bragantia, Campí nas, $\underline{3}: 271-321$.

GUYOT, J. 1969. Mesure des surfaces spécifiques des argiles par adsorption. Ann. Agron., 20 (4):333-359.

HANG, P.T. ; G.W. BRINDLEY, 1970. Methilene blue absortion by clay minerals. Determination of surface areas and cation exchange capacities (Clay-organic studies XVIII). Clay and clay minerals, 18: 203-211.

HASUI, Y. 1969. O cretáceo do Oeste Mineiro. Bol. Soc. Bras. $\underline{\text { Geol., }} \underline{18}(1): 39$

HARRISON, J.B. 1910. IV. The residual earths of Briths Guiana commonly termed "laterite". Geol. Mag., 2:553-562.

HAWKINS, D.B. e R. ROY, 1963. Experimental hydrotermal studies on rock alteration and clay mineral formation. Geochim. Cos mochim. Acta, 27:1047-1053.

HEIM, J.R. ; H.W. YEH e E. ALEXANDER. 1979. Origin of ironrich montmorillonite from the manganese nodule belt of the North Equatorial Pacific. Clay and Clay Minerals, 27 (3): 185-194.

HERBILLON, A.J. ; A. GALLEZ e A.S.R. JUO, 1977. Characterists of silica sorption and solubility as parameters to evaluate the surface properties of tropical soils: II. The index of silica saturation. Soil. Sci. Soc. Am. J., 41:1151-1154.

HUMPHRIS, S.E. e G. THOMPSON, 1978. Trace element mobility du ring hydrotermal alteration of oceanic basalts. Geochimica 
et Comochimica Acta, 42: 127-136.

HUMPHRIS, S.E. e G. THOMPSON, 1978a. Hydrotermal alteration of oceanic basalt by seawater. Geochimica et Cosmochimica Acta 42: $107-125$.

HUNSAKER, V.E. e P.F. PRATT, 1971. Calcium-magnesium exchange equilibrio in soils. Soil Sci. Soc. Am. Proc., 35:151-152. HSU, P.H. e F.T. BATES, 1964. Fixation of hydroxy - aluminium polymers by vermiculite. Soil Sci. Soc. Am. Proc., 28: 763769 .

HSU, P.H. 1968. Heterogeneity of montmorillonite surface and its effect on the nature of hydroxy-aluminium inter layers. Clays Clay Minera1., 16:303-311.

IGUE, K. ; H. GARGANTINI e M. ALCOVER. 1970. Efeito da calagem e da adubação fosfatada em solo ácido e de baixa fertilidade na cultura do trigo. Bragantia, 29(5):59-66.

I.P.I. 1977. Potasium dynamics in the soil. I.P.I. EXTENSION GUIDE. International Potash Institute. Bern / Switzerland, $11 \mathrm{p}$.

I.R.A.T. 1975. Les recherches en agronomie de l'IRAT de 1969 a 1974. Agron. Trop., 30(2): 107-178.

JENSEN, H.E. 1975. Seletivity coefficients of mixtures of ide a1 cation-exchanges. Agrochimica, 29 (3, 4): 257-261.

JACKSON, M.L. 1963. Aluminium bonding in soils. A unifying prin ciple in soil science. Soil Sci. Soc. Am. Proc., 27:1-10. JENSEN, H.E. 1973a. Potassium - calcium exchange equilibria on a montmorillonite and a kaolinite clay. I. A test on the 
Argensinger thermodynamic approach. Agrochimica, 17 (3, 4): $181-201$.

JENSEN, H.E. 1973b. Potassium - calcium exchange equilibria on a montmorillonite and a kaolinite clay. II. application of double-layer theory. Agrochimica, 17(3,4):191-201.

KAPOOR, B.S. 1972. Clay Miner., 9:425-432, in: KAPOOR, B.S. and S.C. GOSWAMI, 1978. Acid character of dioctaedral vermiculi te: permanent and $\mathrm{pH}-$ dependent charge components of cation exchange capacity. J. Ind. Soc. Soil Sci., 26(4):332-338

KAPOOR, B.S. and S.C. GOSWAMI, 1978. Acid character od dioctae dral vermiculite: permanent and $\mathrm{pH}$-dependent charge compo nents of cation exchange capacity. J.Ind. Soc. Soil Sci.,26 (4) $: 332-338$.

KENNEDY, W.Q. 1933. Trends of differentiation in basaltic mag mas. Am. Jour. Sci., $5^{\text {th }}$ series, 25:239-256.

KINNIBURG, D.G. ; J.K. SYERS e M.L. JACKSON, 1975 . Specific adsorption of trace amounts of calcium and strontium by hidrous oxides of iron and aluminium. Soil Sci. Soc. Am. Proc., 39: 464-470.

KONNS, R.D. ; P.A. HELMKE e M.L. JACKSON, 1980. Associaton of trace elements with iron oxides during rock weathering. Soil Sci. Soc. Am. J., 44: 156-159.

KRISHNAMOORTHY, C. e R. OUERSTREET, 1949. Theory of i on-exchan ge relationships. Soil Sci., 68:307-315.

LADEIRA, E.A. e O.E. ALVES DE BRITO, 1968. Contribuição à geo logia do Planalto da Mata da Corda. Anais $22^{\circ}$ Congresso Bras. 
Geol., p. 181.

LACOURT, F. 1934. Contribuição à geologia do Triângulo Mineiro, Minas Gerais. Anais da Esc. de Minas de Outro Preto, $25: 29$.

LAUDELOUT, H. ; R. Van BLAdEL ; G.H. BOLT e A.L. PAGE, 1968. Thermodynamics of heterovalent cation exchange sorption in the systems sodium-cesium-barium montmorillonite. J. Phys. Chem. 6 6:1781-1783.

LAMEB, T.W. e R.T. MARTIN, 1955. Composition and Enginneering Properties of soil (III) Higahway Research Board. Proc.34 Annual Meeting, Washington, D.C.

LEE, R. e J.P. WIDDOWSON, 1977. The potassium status of some representative soils from the Kingdom of Tonga. Trop. Agric. (Trinidad), $54(3): 251-263$.

LEINZ, V. 1949. Contribuição à geologia dos derrames basáit cos do sul do Brasil. Bol. Fac. Fil. Cien. Let., USP, São Paulo, n 103, Geologia, n 5. 61 p.

LEITE, R. ; H. GARGANTINI, L.S. HUNGRIA e T. IGUE, 1970. Efe tos do nitrogênio, fósforo, calcáreo e micronutrientes em solos de cultura de arroz irrigado no Vale do Paraíba. Bra gantia, $29(5): 273-285$.

LEONARDOS, O.H. 1956. Recursos minerais do Triângulo Mineiro, MG. Engenharia, Miner. e Metal., 24 (140):711-732.

LONGSTAFF, W.H. e E.R. GRAHAM, 1951. Release of mineral magne sium and its effect on growth and compostion of soybeans. Soil Sci., 71: (2) 167-174. 
LOTTI, G. e R. RIFFALDI, 1978. I colloidi inorganici non argillosi del suolo. Agrochimica, 22(3, 4): 179-215.

MAES, A. e A. CREMERS, 1975. Cation-exchange hystereses in montmorillonite: A pH-dependent effect. Soil Sci., 119(3): $198-202$.

MAES, A. e A. CREMERS, 1977. Charge density effects in ion exchange. I. Heterovalent exchange equilibria. J. Chem. Soc. Faraday Trans., 173:1807-1814.

MAES, A. e A. CREMERS, 1978. Charge density effects in ion ex change. II. Homovalent exchange equilibria. J. Chem. Fara day Trans., 174:1234-1241.

MAES, A. ; M.S. STUL e A. CREMERS, 1979. Layer charge-cationexchange capacity relationship in montmorillonite.clays and clay minerals, 27(5): 387-392.

MALlaVOLTA, E. e T. COURY, 1954. Postilas de práticas de Quími ca Agrícola. Piracicaba, Centro Acadêmico "Luiz de Queiroz" $49 \mathrm{p}$.

MALQUORI, A. 1978. I colloidi minerali nel suolo: ricerche svolte in Italia. Agrochimica, 22(3, 4): 164-178.

MASCARENHAS, A.A. ; S. MIYASAKA, T. IGUE e E.S. FREIRE, 1970. Adubação da soja. VIII. Efeito de doses crescentes de calcá reo, fósforo e potássio em solo Podzólico Vermelho Amarelo, variação Piracicaba. Bragantia, 29: 81-89.

MARSAHLL, C.E. 1964. The physical chemistry and mineralogy of soils. Vol. 1: Soil materials. Willey and Sons, N.Y., 388p. MARTINI, J.A. 1966. Caracterizacion del estado de potássio en 
seis suelos de Panama. Fitotecnia Latinoamericana, $\underline{3}: 163-$ 186.

MATTSON,S. 1974. Ionic relationships of soil and plant. V. Ion uptake in relations to valence, membrane activity and soil moisture. Acta Agriculturae Scandinavica, 24(1):33-36.

MATTSON, S. e K.G. LARSSON, 1946. The laws of soil colloidal behavior: Donnam equilibria in soil formation. Soil Sci., 61: $313-330$.

MAY, H.M. 1973. M.S. thesis, Dept. Soil Science, Univ. Wiscon sin, Madison U.S.A. in: Violante, P. e A. Violante - 1980Characterization of $\mathrm{H}-\mathrm{Bentonites}$ and interpretation of the third buffer range appearing on $\mathrm{pH}$ titration curves. Agro chimica, $24(1): 47-58$.

McBRIDE, M.B. 1979. An interpretation of cation selectivity va riations in $\mathrm{M}^{+}-\mathrm{M}^{+}$exchange on clays. Clays and clay Minerals, $27(6): 417-422$.

MCLEAN, E.O. e C.E. MARSHALL, 1948. Reciprocal effects of Ca an $K$ as shown by their cationic activities in montmorilloni te. Soil Sci. Soc. Am. Proc., 13:179-182.

MCLEAN, E.0. 1971. Potentially beneficial effects from liming: chemical and physical. Soil Crop Sci. Soc. Fla. Proc., 31: 189-196.

MCLEAN, E.0. e V.C. BITTENCOURT, 1974. Complementary ion effects on potassium and calcium displacement from tri-ionic bentonite and illite systems as affected by pH-dependent charges. Soil Sci., 17(3):103-109. 
MEKARU, T. e G. UEHARA, 1972. Anion adsorption in ferruginous tropical soils. Soil Sci. Soc. Am. Proc., 36:296-300.

MENDES, A.C.T. 1970. Dispersão de amostras de solos minerais. Departamento de Solos e Geologia ESAL//USP. Piracicaba, 47p. MIELNICZUK, J. 1978. O potássio no solo. Boletim n². Institú to da Potassa e Fosfato. Programa comum no Brasil - Piracicaba. $80 \mathrm{p}$.

MILLOT, G. 1964. Geologie des argiles. Masson et Cie, Paris. $499 \mathrm{p}$.

MITRA, R.P. e B.S. KAPOOR, 1969. Components of cation exchange. Soil Sci, 108: 11-18.

MIYASAKA, S. ; E.S. FREIRE; T. IGUE e M. CAMPANA, 1966. Adubação mineral do feijoeiro. II. Efeitos de N, P, K, da cala gem e de uma mistura de enxofre estruturada. Bragantia, 23 (13) : 145-159.

MOHR, E.C.J. e F.A. VAN BAREN, 1954. Tropical Soils. New York, Interscience Publishers. $498 \mathrm{p}$.

MONIZ, A.C. e M.L. JACKSON, 1967. Quantitative mineralogical a nalysis of Brasilian soils derived from basic rocks and sla te. Soil Sci Report, n: 212, Univ. Wisconsin, Madison. 73p. MONIZ, A.C. e A. CARVALHO, 1973. Estudo mineralógico dos solos derivados do arenito Bauru e rochas básicas da regiāo noroeste do Estado de São Paulo. Bragantia, 32:309-335.

MORAES REGO, L.P. 1930. A geologia do Estado de São Paulo. Se parata do Boletim do "D.E.R.". 153 p. MORAIS, F.I. ; A.L. PAGE e J.L. LUND, 1976. Effect of pH, salt 
concentration and nature of electrolytes on charge charac teristics of Brazilian Tropical soils. Soil Sci. Soc. Am.J. 40: $521-527$.

MORITA, T. e R.M.V. ASSUMPÇAO, 1976. Manual de soluções, Rea gentes e Solventes. Ed. Edgar Blucher Ltda. São Paulo 627p. MOSS, P. e J.K. COULTER, 1964. The potassium status of West Indian volcanic soils. J. Soil Sci., 15:284-298.

MUNNS, D.N. 1976. Heterovalent cation exchange equilibria in soils with variable and heterogeneous charge. Soil Sci.Soc. Am. J., $\underline{48}: 841-845$.

MUNNS, D.N. e R.L. FOX, 1977a. Stabilization of calcium by sur face charge variation in an oxisol. Soil Sci. Soc. Am. J., 41: $682-685$.

MUNNS, D.N. e R.L. FOX, 1977b. Comparative lime requirements of tropical and temperate legumes. Plant Soil, 46:533548 .

NAGELSCHMILT, G. 1938. Atomic arrangement and variability of the montmorillonite group. Mineralog. Mag., 25(162):140. NAFADY, M.H. 1972. The sodium potassium exchange sites in soils colloids. Acta Agric. Scand., 22(4): 205-308.

NOVAK, I. e B. CICEL, 1978. Dissolution of smectites in hidro cloric acid: II. Dissolution rate as a function of crystalo chemical composition. Clay and Clay Minerals, 26:341-344. NYE, P.D. ; D. CRAIG, N.T. COLEMAN e J.L. RAGLAND, 1961. Ion exchange equilibria involving aluminium. Soil Sci. Soc. Am. Proc., 25:14-17. 
OBIHARA, C.H. e E.W. RUSSEL, 1972. Specific adsorption of sili cate and phosphate by soils. J. Soil Sci., 23(1):105-107.

PABLOS, A.B. de e A.A. da SILVA, 1975. Mejora, con PVA, de las propriedades físicas de un aluviosuelo. Agrochimica, 19 (1) $: 59-72$.

PACCOLA, A.A. 1980. Alterações químicas e mineralógicas de an fibolitos sob condições de drenagem deficiente. ESALQ/USP. Piracicaba, SP. 63 p. (Dissertação de Mestrado).

PAIVA NETTO, J.E. de,1949. A fração argila dos solos do Estado de São Paulo e seu estudo roentgnográfico. Bragantia, Campi pinas, $2: 335-432$.

PAIVA NETTO, J.E. de, 1955. "Eunicita" - nova variedade de mon tmorilonóide encontrado nos meláfiros de compostos da Ser ra de Botucatu. Engenharia, Mineração e Metalurgia, $\underline{22}$ (128): 99 .

PAIVA NETTO, J.E. de e PACCOLA, A.A. 1974. Determinação ele trométrica da CTC. Anais da IV Jornada Científica da FCMBB Botucatu. p. 62 .

PARKS, G.A. e P.L. de BRUYN, 1962. The zero point of charge of oxides. J. Phys. Chem., 66: 967-973.

PARKS, G.A. 1965. The isoeletric points of solid oxides, solid hidroxydes, and aqueous hydroxi complex systems. Chem.Rev., 65: 177-198.

PICHOT, J. 1971. Etude de l'evolution du sol en presence de fumures organiques ou minérals. Cinq années de experimenta tion à la Station de Boukoko, R.C.A. LAgron. Trop., 26 $(6,7): 736-754$. 
PIERI, C. 1976. L'acidification des terres de culture exondées au Sénégal. Agron. Trop., $\underline{31}$ (4):339-368.

PIERI, C. 1977. Mineralogie et proprietes de surface de deux sols sableut du Senegal. Agronomie Tropicale, 32(4): 339351 .

PIGNEUR, P. ; A. MAES e A. CRAMERS, 1975. Heterogeneity of charge density distribution in montmorillonite as inferred from cobalt adsorption. Clays and clay minerals, 23:71-75.

PRATT, P.F. e F.L. BLAIR, 1962. Cation exchange properties of some acid soils of California. Hilgardia, 33:689-693.

QUEIROZ NETO, J.P., 1969. Interpretação dos solos da Serra de Santana para fins de classificação. ESALQ/USP. Piracicaba, $135 \mathrm{p}$. (Tese de Doutoramento).

RAGG, J.M. e D.F. BALL, 1964. Soils of the ultra-basic rocks of the Island of Rhum. J. Soil Sci., 15(1): 57-69.

RAIJ, B. Van e M. PEECH, 1972. Eletrochemical properties of some oxisols and alfixols. Soil Sci. Soc. Am. J., 36: 587593.

RAW, F. e C.A. MATLEY, 1943. Some altered palagonite tuffs from Jamaica and the origin and history of their chlorites. Jour, Geol., 51: 215-243.

REEUWIJK, L.P. Van e VILLIERS, J.M. 1968. Potassium fixation by amorphous aluminosilica gels. Soil Sci. Soc. Am. Proc., 32: $238-240$.

RICE, H.B. e E.J. KAMPRATH, 1968. Availability of exchangeable and monexchangeable $\mathrm{Mg}$ in sandy coastal plain soils. Soil 
Sci. Soc. Am. Proc., 32: 386-388.

RICH, C.I. e S.S. OBENSHAIN, 1955. Chemical and clay mineral properties of a red yellow podzolic soil derived from musco vite schist. Soil Sci. Soc. Am. Proc., 19:334-341.

RICH, C.I. 1968. Mineralogy of soil potassium in the "Role of Potassium in agriculture". Ed. V.S. Kilmer, S.E. Yonts e N.C. Brady. Publ. American Society of Agronomy. Wisconsin, U.S.A. 509 p.

ROLE DE LA MATIERE ORGANIQUE DANS LA FERTILITE DU SOL. 1975. Agronomie Tropicale, 33(2):170-175.

ROSS, L. ; P. NABABSING e Y.W.Y. CHEONG, 1974. Residual effect of calcium silicate apllied to sugarcane soils. Proc. Int. Soc. Sugar Cane Technol., 17-539-542.

ROTINI, 0.T. 1978. La funzione agronomica du colloidi nel terreno agrário. Agrochimica, 33(3, 4): 161-163.

RÜEGG, N.R. 1975. Modelos de variação química na província ba sáltica do Brasil Meridional. Características do teor, dis tribuição geogräfica e diferenciação. Instituto de Geociências, USP, São Paulo - Tese de Livre Docência. Vol. 1. 215 p. Vol. $2-94$.

RUIZ, M.D. 1961. Estudos das características expansivas de uma argila verde que ocorre em rocha basāltica da Barragem de Bariri-SP. Relatório de Pesquisa $n^{\circ} 59$ do I.P.T. São Paulo, $32 \mathrm{p}$.

RUIZ, M.D. 1962. Contribuição ao estudo tecnológico de algumas rochas basálticas do Estado de São Paulo. Escola Politecni ca/USP. São Paulo. 115 p. (Tese de Doutoramento). 
SALMON, R.C. e P.W. ARNOLD, 1963. The uptake of magnesium un der exhaustive cropping. J.Agric. Sci., 61:421-465.

SARBADHIKARI, T.R. e BHATTACHERJEE, S. 1966. Secondary clay in Rajmahal basalts of India and its relation to palagonite chlorophacite. Mineralogical Mag., 35: 770-775.

SCHNEIDER, A.W. 1964. Contribuição à petrologia dos derrames basālticos da Bacia do Paranā. Publ. Avulsa $n^{\circ} 1$, Esc.Eng. Univ. Federal do Rio Grande do Sul. 76 p.

SOHOFIELD, R.K. 1949. Calculation of surface areas from-measurements of negative adsortion. Trans. Br. Ceram. Soc., 48 : 207-213.

SCHOFIELD, R.K. e A.W. TAYLOR, 1955. The measurement of ...soil pH. Proc. Soil Sci. Soc. Am., 19:164-172.

SCHWERTMANN, V. e M.L. JACKSON, 1963. Hydrogen aluminum clays: a third buffer range appearing in potentiometric tritation. Science, 139: 1052-1053.

SCHWERTMANN, V e M.L. JACKSON, 1964. Influence of hydroxid alu minium ions on pH titration curves of hydrogenium aluminium clays. Soil Sci. Soc. Am. Proc., 28: 179-183.

SHALHEVET, J. e L. BERNSTEIN, 1968. Effects of verticaly heterogeneous soil salinity on plant growth and water uptake. Soil Sci., 106(2): 85-93.

SHALSCHA, E.B. ; P.F. PRATT ; T. KINJO e J. AMAR, 1972. Effect of phosphate salts as saturating solutions in cation exchange capacity determinations. Soil Sci. Soc. Am. Proc., 36: 912-914. 
SHALSCHA, E.B. ; P.F. PRATT e D. SOTO, 1974. Effect of phospha te adsorption on the cation exchange capacity determinations. Soil Sci. Soc. Am. Proc., 38:539-540.

SHEN, M.J. e C.I. RICH, 1962. Proc. Soil Sci. Soc. Am., 26:3338. In: KAPOOR, B.S. e S.C. GOSWAMI, 1978. Acid character of dioctahedral vermiculite: permanent and $\mathrm{pH}$-dependent charge components of cation exchange capacity. J.Indian Soc. Soil Sci. Vol. 26(4): 332-338.

SHERMAN, G.D. e UEHARA, G. 1956. The weathering of olivine ba salt in Hawaii and its pedogenic significance. Soil Sci. Soc. Am. Proc., 20 (3): 337-340.

SINBAD, P. 1972. Etude de l'evolution des sols sous culture traditionnelle en Haute - Casamance. Principaux résultats. L'Agron. Trop., 27(5): 574-591.

SINGER, A. 1967. Mineralogy of the non-clay fractions from ba saltic-soils in the Galilee, Israel. Israel J. Earth Sci., 16:215-228.

SINGH, H.P. ; R.P. SINGH e K. SINGH, 1979. Effect of bentonite subsurface moisture on soil-mois ture storage and yield of roundgourd grown in sandy soils. Ind. J.Agric. Sci., $\underline{49}$ (11) : 880-885.

SOUZA SANTOS, P. e M.D. RUIZ, 1962. Identificação dos argilominerais existentes nas placas verdes provenientes da decom posição de rochas basālticas da região de Bariri, Estado de São Paulo. Pesquisa n 78 I.P.T., São Paulo. SOUZA SANTOS, P. e M.D. RUIZ, 1963. Caracterização mineralógi 
ca de algumas argilas que ocorrem em formações basálticas da Barragem de Barra Bonita, Rio Tietê, Estado de São Pau10. Engenharia, 21 242$): 231$.

STEFANSON, R.C. 1973. Polyvinyl alcohol as a stabilizer of sur face soils. Soil Sci., 115:420.

SWHANEY, B.L. 1968. Aluminium interlayers in layer silicates. Effect of $\mathrm{OH} / \mathrm{Al}$ ratio of $\mathrm{Al}$ solution, time of reaction and type of structure. Clays Clay Mineral., 16:157-183.

SMITH, W.W. 1959. Pseudomorphs after olivine in Markle basalt. Mineralogica1 Mag., 32(247): 324-331.

SMITH, W.W. 1960. Some interstratified clay minerals from ba sic igneous rocks. Clay and Clay Minerals, $4(24): 182$.

TARZI, J.G. e R. PROTTZ, 1979. Increased selectivity of naturally weathered biotite for potassium, Soil Sci. Soc. Am.J. 43: $188-191$.

TELLA, R. ; V.V. FILHO ; J.L.V. ROCHA ; E.S. FREIRE e T. IGUE, 1970. Efeito de doses crescentes de nitrogênio, fósforo e potássio sobre a produção de amendoim em solos Podzolizados de Lins e Marília. Bragantia, 29(19):199-205.

THOMAS, G.W. 1960. Forms of AI in cation exchange. Trans. Int. Cong. Soil Sci. $7^{\text {th }}$. Madison. p. 211-218.

UEHARA, G. e G.P. GILLMAN, 1980a. Charge characteristics of soils with variable and permanent charge minerals: I. The으 ry. Soil Sci. Soc. Am. J., 44: 250-252.

UEHARA, G. e G.P. GILLMAN, 1980b. Charge characteristics of soils with variable and permanent charge minerals: II Expe 
rimental. Soil Sci. Soc. Am. J., 44:252-255.

Van BLADEL, R. e H. LAUDELOUT, 1967. A thermodynamic study of sodium-strontium exchange on wyoming bentonite. Proc.Inter. Clay Conf., 1: $: 19-634$.

Van OLPHEN, H. 1962. An introduction of clay colloid chemis try. Interscience Publishers. New York. 381 p. VELLY, J. 1974. Observation sur l'acidification de quelques sols de Madagascar. L'Agronomie Tropicale, 29(6):1249-1262. VERDADE, F.C. ; W.R. VENTURINI ; A.Z. AMARAL e A.C.P. WUTKE, 1966. Níveis de fertilidade do solo para a cultura algodoe $\underline{i}$ ra. II. Correlação entre a produção e o teor de fósforo no solo. Bragantia, 25(4):41-55.

VIOLANTE, P. e A. VIOLANTE, 1973. La titulazione potenciométrí ca delle bentoniti insature: interpretazione del terzo tra tto tamponato. Ann. Fac. Sci. Agr. Portici. 4:112-120. In: VIOLANTE, P. e A. VIOLANTE, 1980. Characterization of H-Bentonites and interpretation of the third buffer range appearing on pH tritation curves. Agrochimica, 28 (1):47-58.

VIOLANTE, P. e A. VIOLANFE, 1978. Potenciometric titration of aluminium bentonite in the presence of aluminium hydrous xide ge1. Soil Science, 126: 136-144.

VIOLANTE, P. e A. VIOLANTE, 1980. Characterization of H-Bentonites and interpretation of the third buffer range appea ring on pH titration curves. Agrochimica, 24(1):47-58.

WIKLANDER, L. 1946. Studies on ionic exchange with special re ference to the conditions in soils. Ann. Roy. Agr. Coll. 
Sweden, 14: 1-171.

WIKLANDER, L. e GIESEKING, J.E. 1948. Exchangeability of adsor bed cations as influenced by the degree of saturation and the nature of the complementary ions with special reference to trace concentrations. Soil Sci, 66: 377-384. WIKLANDER, L. 1951. Equilibria in ion exchange. I. Influence of the proportions of the exchanging ions. Acta Agricultu rae Scandinavica. $1(2):$ 190-202.

WIKLANDER, L. 1965. Cation and anion exchange phenomena. p. 163-205. In: Chemistry of the soil. F.E. Bear (ed.) Reinhold, London. $521 \mathrm{p}$.

WIKLANDER, L. 1970. Utlakning au näringsamnen. I. Halten i dra neringswatten. Grundfbrbattring, 23: 117-141.

WIKLANDER, L. 1974. Leaching of plant nutrients in soils. I. General principles. Acta Agric. Scand., 24 (4):349-356. WILLIANS, B.G. ; D.Y. GREENLAND e Y.P. QUIRQ, 1967. The effect of polyvinyl alcohol on the nitrogen surgace area and pore structure of soils. Aust. Journ. Soil Res., $\underline{5}: 77-85$. ZANDONADI, A.R. 1972. Estudo tecnológico de argilas nontroníti cas brasileiras. Instituto de Química/USP. São Paulo. 137p. mais apêndices (Tese de Doutoramento). 


\section{APENDICE}

Abreviaturas e Constantes Utilizadas

a - atividade iônica.

$\beta-1,06 \times 10^{15}(\mathrm{~cm} / \mathrm{meq})$

CTA - capacidade de troca aniônica meq/100g.

CTC - capacidade de troca catiônica meq/100g.

$\mathrm{Cl}^{-}$rep. - repulsão de cloreto.

$\Delta \mathrm{pH}$ - diferença entre $\mathrm{pH}$ em solução de eletrólito e pH em água.

$\varepsilon$ - constante dielētrica do meio.

e - carga do eletron $=1,602 \times 10^{-19}$ coul $=4,8 \times 10^{-10}$ esu.

esu $=3,336 \times 10^{-10}$ coul $=1$ stcoul $=3,456 \times 10^{-15} \mathrm{~F}$.

F - constante de Faraday $=2,894 \times 10^{14}$ esu.

$f$ - coeficiente de atividade.

$\mathrm{H}_{\mathrm{O}}^{+}$- concentração de ions $\mathrm{H}^{+}$quando o valor das cargas variāa veis é igual a zero.

$\gamma$ - carga total de superfície $=\left(\mathrm{K}^{+}-\gamma_{\mathrm{a}}^{-}\right)$meq/100g.

$\gamma_{\mathrm{a}}^{-}$- adsorção negativa de anions em meq/100g.

$\gamma_{c}^{-}$- adsorção negativa de cátions em meq/100g.

$\gamma_{a}$ - adsorção de anions em meq/100g.

$\Gamma$ - densidade de carga total em meq/ $\mathrm{cm}^{2}$.

$\Gamma^{-}$- adsorção negativa em meq/ $\mathrm{cm}^{2}$.

K - coeficiente em função da concentração eletrolítica do meio

$K_{g}$ - constante de seletividade de Gapon.

$\mathrm{K}_{\mathrm{C}}$ - constante de seletividade segundo McBride.

$k$ - constante de Boltzmann 1,38054 $\cdot 10^{-16}$ erg.gran ${ }^{-1} \cdot$ molécula $^{-1}$

m - concentração molar de eletrólito. 
M - basalto alterado.

$\mathrm{N}$ - concentração da solução interna em meq/ $\mathrm{cm}^{3}$.

$\mathrm{N}_{1}$ - número de sítios viáveis para adsorção de íons.

$\mathrm{n}$ - concentração de eletrólitos em ions $/ \mathrm{cm}^{3}$.

$\mathrm{NA}$ - número de Avogrado $=6,02 \times 10^{23}$ ions $/ \mathrm{mol}$.

n.d. - não determinado.

n.c. - não calculável.

n.t. - não tem.

$\delta$ - espessura da camada de Stern.

$\theta$ - teor de umidade no solo em $:$

$\sigma_{v}$ - densidade de cargas variáveis esu/cm ${ }^{2}$ ou meq/100g.

$\sigma_{\mathrm{p}}$ - densidade de cargas permanentes esu/cm ${ }^{2}$ ou meq/100g.

$\sigma_{t}$ - densidade de carga total meq/100g.

$\phi$ - energia de adsorção específica.

$\rho$ - densidade do solvente.

$\psi_{0}$ - potencial elëtrico da superfície.

$\psi_{\delta}$ - potencial elétrico na ligação entre a camada de Stern : e camada difusa.

$\mathrm{pH}--\log \mathrm{H}^{+}$.

$\mathrm{pHo}--\log \mathrm{H}_{\mathrm{O}}^{+}$

Q/I - relação quantidade/intensidade.

$q$ - fator de valência.

RA (ou AR) - relação de atividades.

sinh - seno hiperbólico.

$S$ - superfície específica total em $\mathrm{cm}^{2} / 100 \mathrm{~g}$.

$\mathrm{S}_{\mathrm{v}}$ - superfície específica de cargas variāveis $\mathrm{m}^{2} / \mathrm{g}$. 
$S_{p}$ - superfície específica de cargas permanentes $\mathrm{m}^{2} / \mathrm{g}$.

$\mathrm{T}$ - temperatura absoluta ${ }^{\circ} \mathrm{K}$.

z - carga do ion considerado.

ZPC (ou PCZ) - ponto de carga variável igual a zero.

ZPNC (ou PCIZ) - ponto de carga Iíquida igual a zero. 
A ciência construirá para o homem o clima do conforto e enriquece-1o-á com os brasões da cultura superior; a filosofia auxilia-lo-á com valio sas interpretações dos fenômenos em que a Eterna Sabedoria se manifesta, mas somente a fé, com os seus estatu tos de perfeição intima, consegue preparar nosso espírito imperecível para a ascensão à glória universal. 